\title{
HYDROLOGY OF AREA 52, ROCKY MOUNTAIN COAL PROVINCE, WYOMING, COLORADO, IDAHO, AND UTAH
}

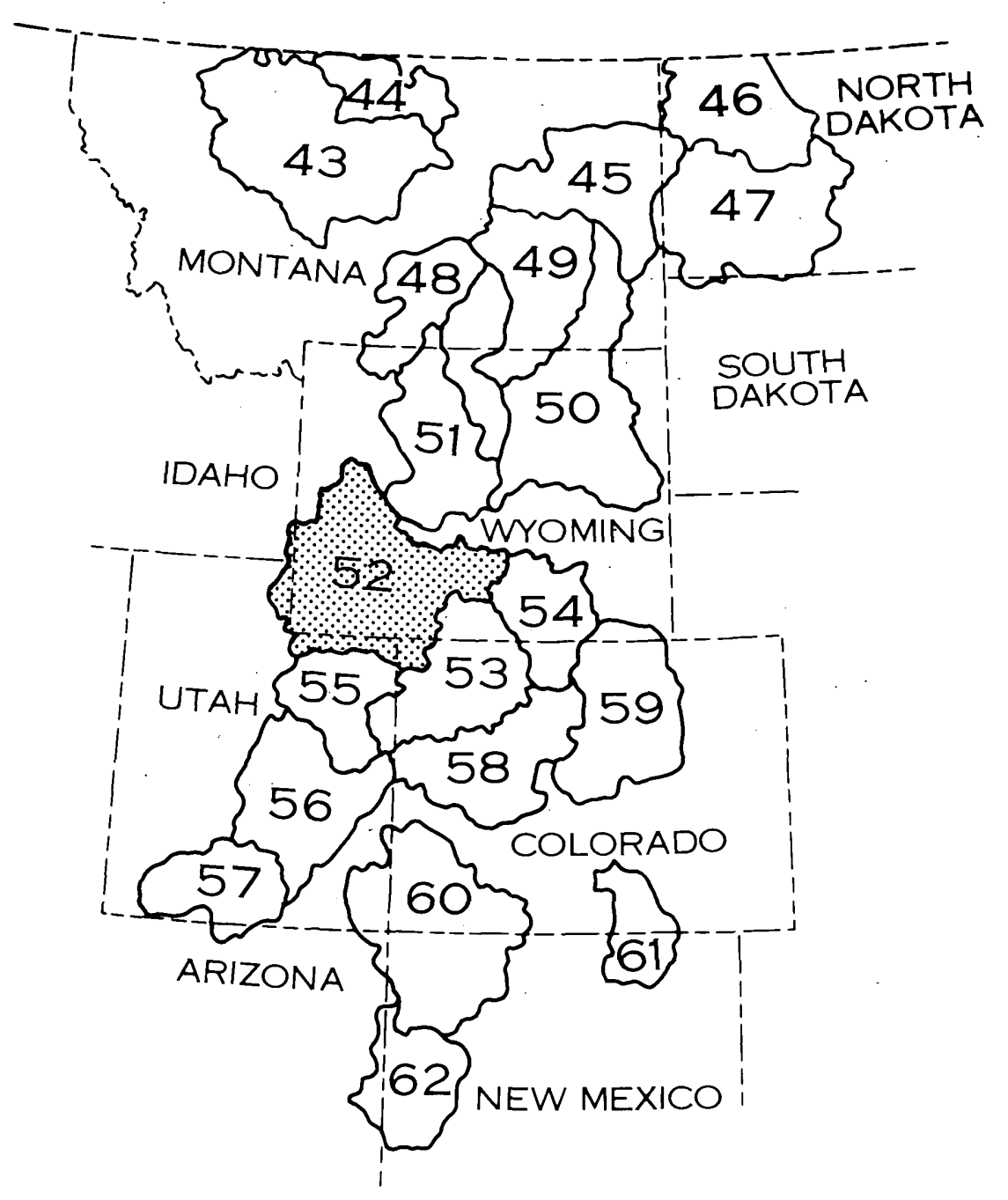

- GREEN RIVER

- NEW FORK RIVER

- BIG SANDY RIVER

- BLACKS FORK

- BEAR RIVER

- gREAT DIVIDE BASIN

UNITED STATES DEPARTMENT OF THE INTERIOR GEOLOGICAL SURVEY 


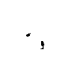




\section{HYDROLOGY OF AREA 52, ROCKY MOUNTAIN COAL PROVINCE, WYOMING, COLORADO, IDAHO, AND UTAH}

BY

H. W. LOWHAM, DAVID A. PETERSON, L. R. LARSON, E. A. ZIMMERMAN, BRUCE H. RINGEN, AND K. L. MORA

U.S. GEOLOGICAL SURVEY

WATER-RESOURCES INVESTIGATIONS

OPEN-FILE REPORT 83-761 OCTOBER, 1985 


\title{
UNITED STATES DEPARTMENT OF THE INTERIOR
}

\author{
WILLIAM P. CLARK, SECRETARY
}

\section{GEOLOGICAL SURVEY}

\author{
Dallas L. Peck, Director
}

For additional information write to:

District Chief

U.S. Geological Survey

Water Resources Division

P.O. Box 1125

Cheyenne, Wyoming 82003 


\section{CONTENTS}

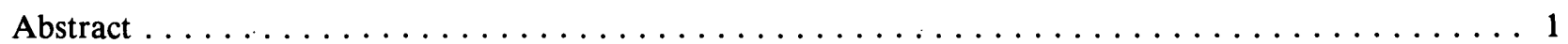

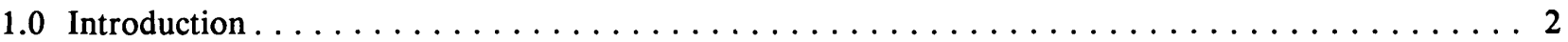

K. L. Mora

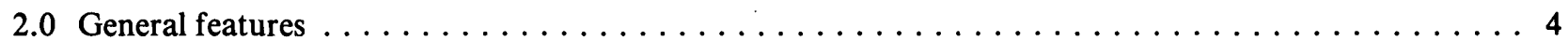

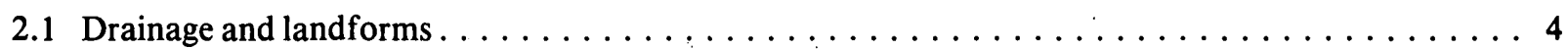
H. W. Lowham

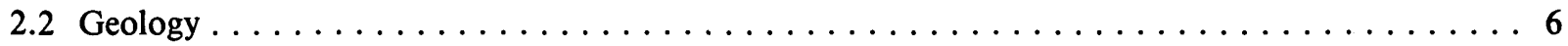
E. A. Zimmerman

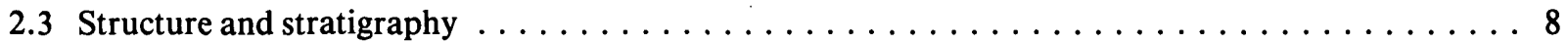
E. A. Zimmerman

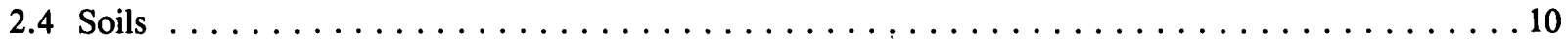
R. L. Daddow, U.S. Forest Service

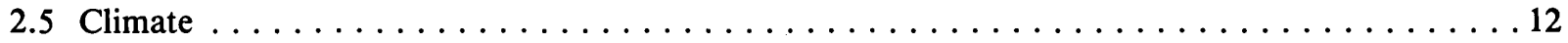
H. W. Lowham

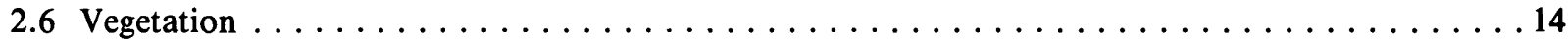
David A. Peterson

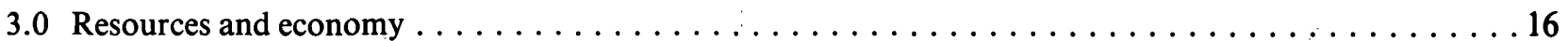

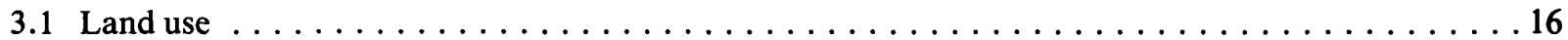
David A. Peterson

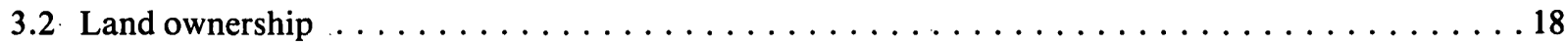
David A. Peterson

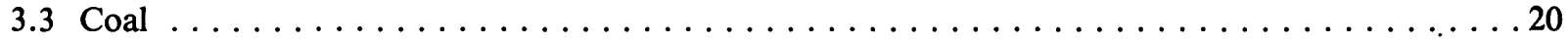
E. A. Zimmerman (U.S. Geological Survey) and Gary B. Glass (Wyoming State Geologist)

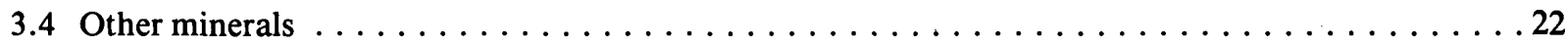
E. A. Zimmerman

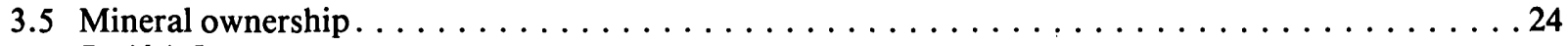
David A. Peterson

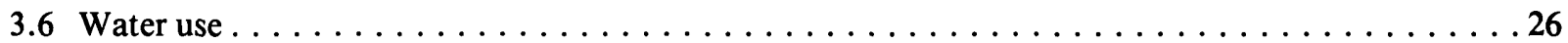
H. W. Lowham

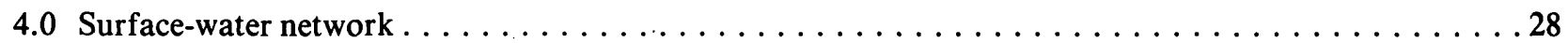

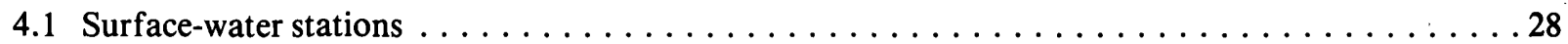
H. W. Lowham

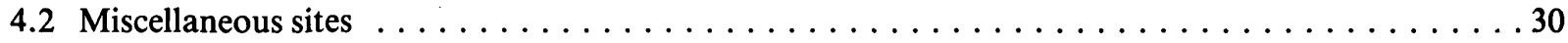
H. W. Lowham

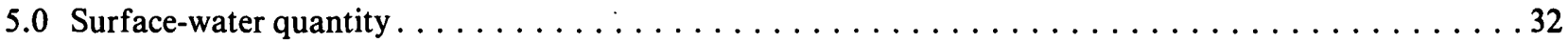

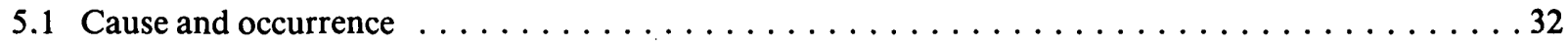
H. W. Lowham

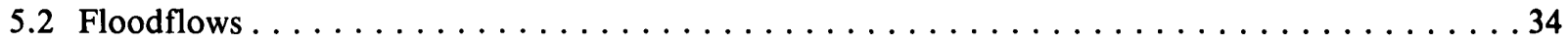
H. W. Lowham and Bruce H. Ringen 


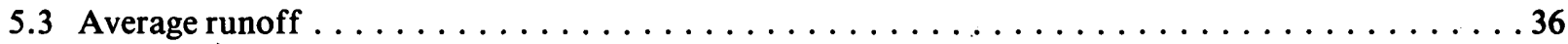
H. W. Lowham

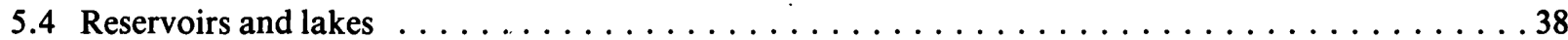
David A. Peterson

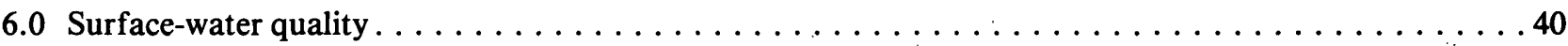

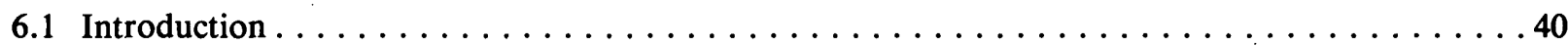
David A. Peterson

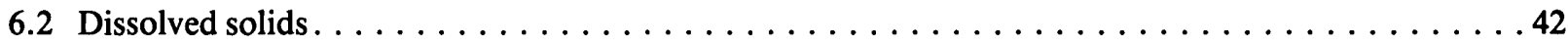
L. R. Larson

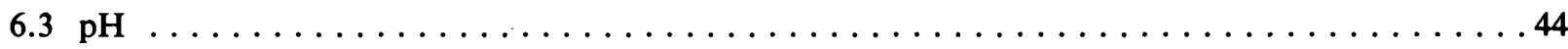
L. R. Larson

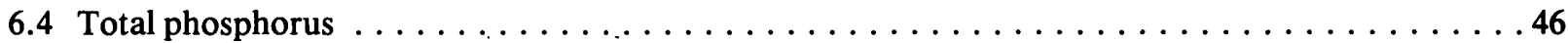
L. R. Larson

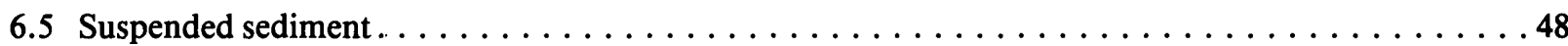
Bruce H. Ringen

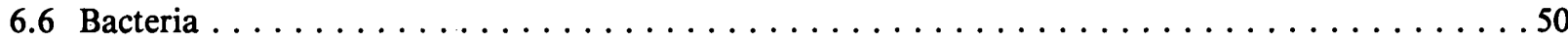
David A. Peterson

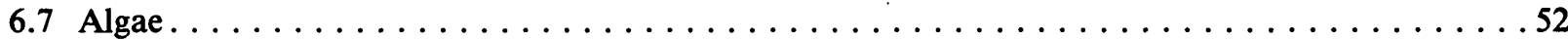
David A. Peterson

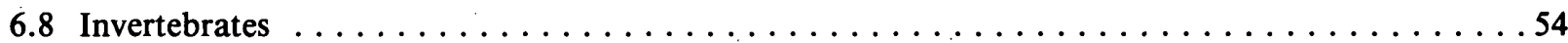
David A. Peterson

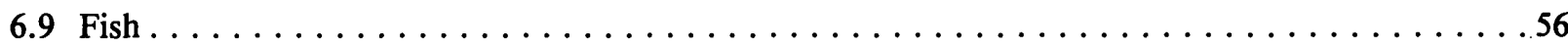
David A. Peterson

6.10 Temperature . . . . . . . . . . . . . . . . . . . . . . . . . . . 58 H. W. Lowham

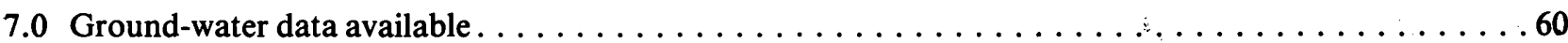
E. A. Zimmerman

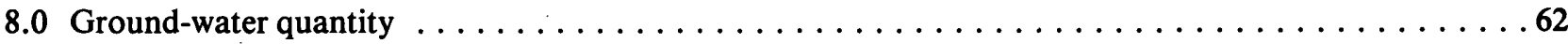

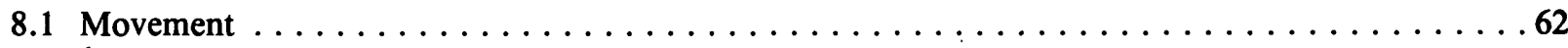
E. A. Zimmerman

8.2 Aquifer potential. . . . . . . . . . . . . . . . . . 64 E. A. Zimmerman

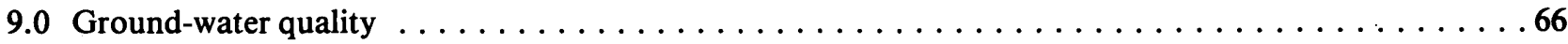

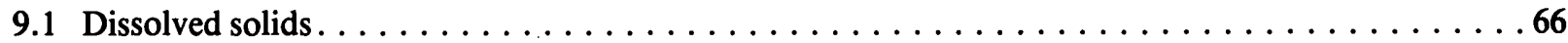
L. R. Larson

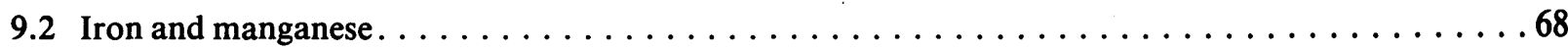
L. R. Larson

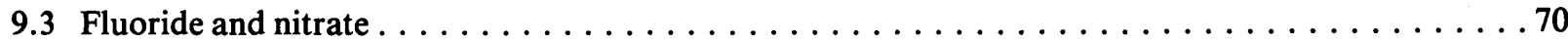
L. R. Larson

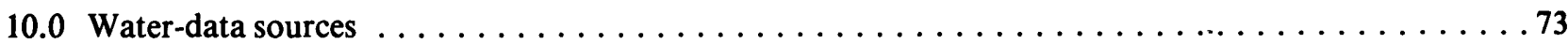

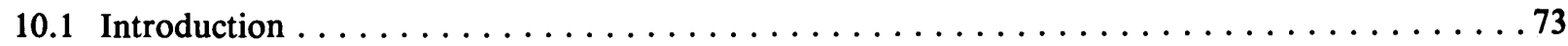

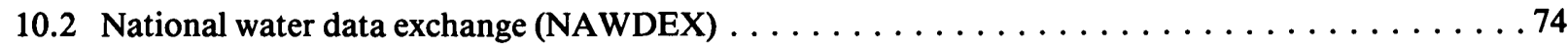

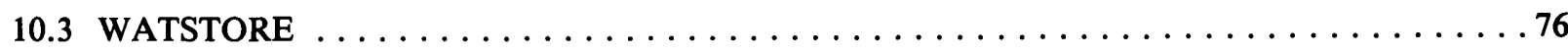

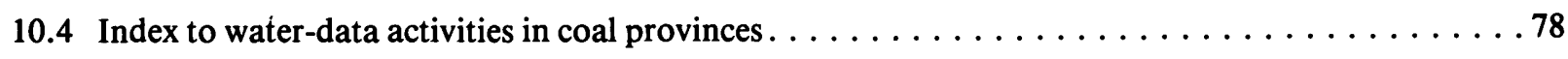

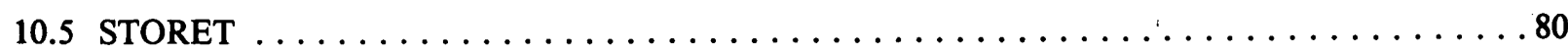




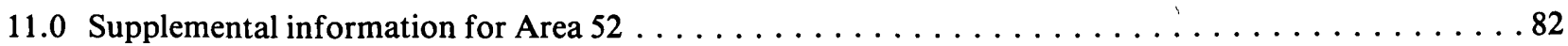

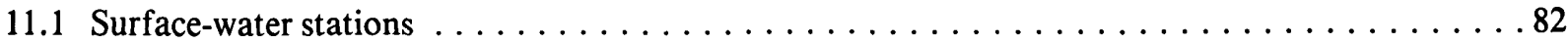

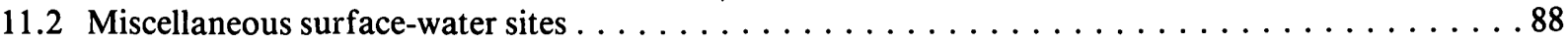

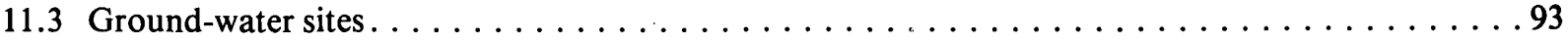

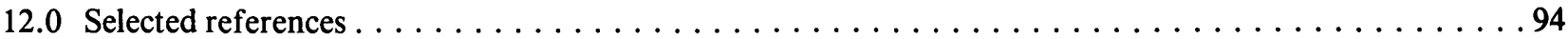




\section{FACTORS FOR CONVERTING INCH-POUND UNITS TO INTERNATIONAL SYSTEM OF UNITS (SI)}

\section{For the convenience of readers who may want to use the International System of Units (SI), the data may be converted by using the following factors:}

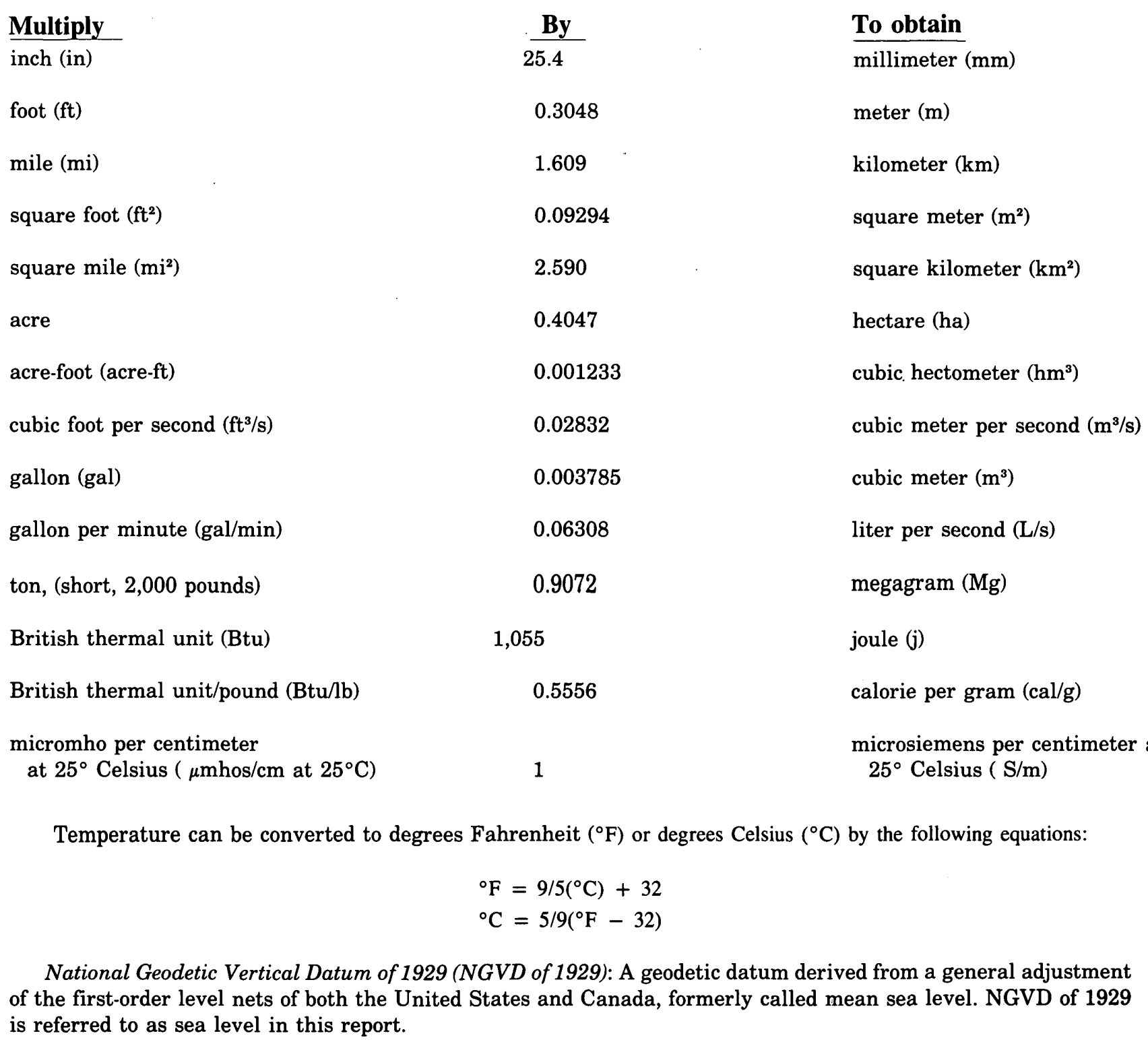

\section{Multiply}

foot $(\mathrm{ft})$

square foot $\left(\mathrm{ft}^{2}\right)$

square mile $\left(\mathrm{mi}^{2}\right)$

acre

cubic foot per second $\left(\mathrm{ft}^{3} / \mathrm{s}\right)$

gallon (gal)

gallon per minute (gal/min)

ton, (short, 2,000 pounds)

British thermal unit (Btu)

British thermal unit/pound (Btu/b)

micromho per centimeter

at $25^{\circ}$ Celsius $\left(\mu \mathrm{mhos} / \mathrm{cm}\right.$ at $\left.25^{\circ} \mathrm{C}\right)$

\section{$\frac{\text { By }}{25.4}$}

0.3048

2.590

0.02832

0.003785

0.06308

0.9072

0.5556

1

\author{
To obtain \\ millimeter $(\mathrm{mm})$ \\ square meter $\left(\mathrm{m}^{2}\right)$ \\ square kilometer $\left(\mathrm{km}^{2}\right)$ \\ hectare (ha) \\ cubic hectometer $\left(\mathrm{hm}^{3}\right)$ \\ cubic meter per second $\left(\mathrm{m}^{3} / \mathrm{s}\right)$ \\ cubic meter $\left(\mathrm{m}^{3}\right)$ \\ liter per second $(\mathrm{L} / \mathrm{s})$ \\ megagram $(\mathrm{Mg})$ \\ joule (j) \\ calorie per gram $(\mathrm{cal} / \mathrm{g})$ \\ microsiemens per centimeter at \\ $25^{\circ}$ Celsius ( $\mathrm{S} / \mathrm{m}$ )
}

Temperature can be converted to degrees Fahrenheit $\left({ }^{\circ} \mathrm{F}\right)$ or degrees Celsius $\left({ }^{\circ} \mathrm{C}\right)$ by the following equations:

$$
{ }^{\circ} \mathrm{C}=5 / 9\left({ }^{\circ} \mathrm{F}-32\right)
$$

of the first-order level nets of both the United States and Canada, formerly called mean sea level. NGVD of 1929 is referred to as sea level in this report. 


\title{
HYDROLOGY OF AREA 52, ROCKY MOUNTAIN COAL PROVINCE, WYOMING, COLORADO, IDAHO, AND UTAH
}

BY

H. W. LOWHAM, DAVID A. PETERSON, L. R. LARSON, E.A. ZIMMERMAN, BRUCE H. RINGEN, AND K. L. MORA

\begin{abstract}
This report describes the physical and hydrological features of Area 52, a hydrologic division in the Rocky Mountain Coal Province. Area 52 consists of approximately 23,870 square miles, most of which is in Wyoming but extends into parts of Colorado, Idaho, and Utah. Altitudes range from 5,300 to 13,785 feet above sea level. Major drainages of the area include the Green River, the Great Divide Basin, and the Bear River.

The Federal Government owns most of the land surface and mineral rights in Area 52. Livestock grazing is the most common land use, and irrigation consumes the largest amount of water. Semiarid sagebrush grasslands predominate on the plains; coniferous forests predominate in the mountains. Differences in soils of the area are mainly due to geologic and climatic conditions. The area contains more than 3 billion tons of strippable, low-sulfur coal, most of which is in the arid and semiarid plains. Vast amounts of oil and gas, oil shale; phosphate, uranium, and trona are produced from the area. Reservoirs are used for irrigation storage, municipal and industrial supply, power development, flood control, fish and wildlife habitat, recreation, and storage to meet water compact requirements.

The quantity of surface-water runoff largely depends upon precipitation, most of which is in the form of snow. The headwaters of the major streams are in the mountainous areas where precipitation is greatest. Chemical, sediment, and biological samples indicate excellent water quality in many streams draining the mountains. However, the water quality decreases from fair to poor in a downstream direction in many of the plains streams.

to increase the dissolved-solids and suspended-sediment concentrations and affect water temperature. Large totalphosphorus concentrations from streams in the plains are causing accelerated eutrophication in the reservoirs, potentially damaging to the water quality of the reservoirs. Surface water in the areas of active coal mining is slightly alkaline and well buffered; acid mine drainage is not a problem.

Ground-water reconnaissance studies have been done on most of Area 52. Some wells and springs in the area yield more than 5,000 gallons per minute, but most yield about 20 gallons per minute. Most wells are completed in sandstone aquifers at depths less than 500 feet.

Good quality ground water is not available everywhere. Large dissolved-solids concentrations are present in most wells and springs; however, wells and springs nearer the mountain recharge areas have better quality water. Fluoride and nitrate concentrations are occasionally large; large manganese and iron concentrations are less common.

The U.S. Geological Survey has collected hydrologic data and made interpretive studies in Area 52 since the late 1800's. A large extent of the present hydrologic knowledge of the area can be attributed to work done in cooperation with State and other Federal Agencies-particularly the Wyoming State Engineer's Office, the Wyoming Department of Environmental Quality, the Wyoming Department of Agriculture, the U.S. Bureau of Land Management, the U.S. Bureau of Reclamation, and the U.S. Environmental Protection Agency.
\end{abstract} Natural processes (such as erosion) and activities of man, such as irrigation, water storage, and waste disposal tend 


\title{
1.0 INTRODUCTION
}

\section{Hydrologic Environment Can Be Drastically Changed by Surface Mining}

\author{
Knowledge of the hydrologic conditions is essential for proper planning of mining \\ and reclamation; a summary of the hydrology and sources of hydrologic \\ information for Area 52 is presented in this report.
}

The use of coal has increased substantially in the United States during recent years. Development of coal resources often requires surface mining, which significantly changes the natural environment (fig. 1.0-1). The magnitude of surface-mining impacts on the hydrologic environment depends on factors that are unique to each site. These factors include mining and reclamation methods, slope of land, type of soil and rock, amount of precipitation, quality of ground and surface waters, and rate of water movement.

Extensive underground mining of coal took place in Area 52 during the early 1900's. Problems that have resulted from that activity include subsidence in Rock Springs, Wyo., and erosion of channels due to inflow from mine dewatering (figs. 1.0-2 and 1.0-3).

Surface mining of coal in the area is currently (1983) being done at seven mines (fig. 1.0-4). Part of the coal is used to fire two powerplants. The removal of vegetation and overburden from large areas has the potential to affect water resources in and near the mined area (fig. 1.0-5). For example, ground-water levels may decline during mining if excavation extends below the water table. This decline can cause subsidence and also cause wells and springs to go dry. Much of the area that can be strip mined has an arid climate, and revegetation of mined areas is likely to be difficult (fig. 1.0-6). Changes in soil-infiltration rates and in vegetation cover can cause changes in the amount and quality of surface runoff.

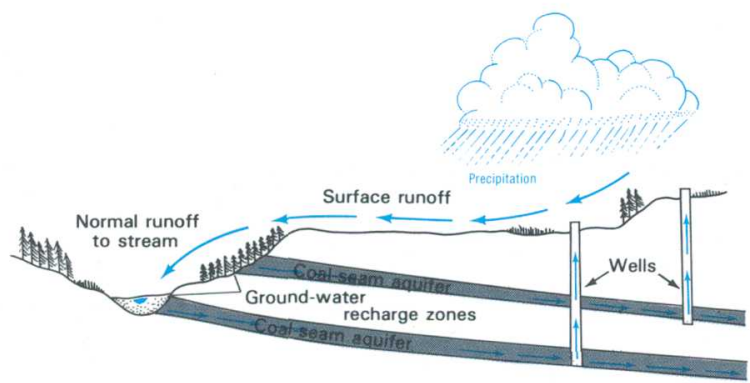

UNDISTURBED CONDITION
Because of the potentially adverse impacts of coal mining, the Surface Mining Control and Reclamation Act of 1977 was enacted August 3, 1977 (Public Law 95-87). This Act requires an appropriate Federal or state agency to issue mining permits partially on the basis of the assessment of the hydrologic impacts in the miningpermit area. As a result, hydrologic information is required to enable the surface-mine industry and consultants to prepare the required permit applications and to enable regulatory authorities to appraise the adequacy of the permit applications.

This report presents a broad summary of the physical and hydrologic features of Area 52, one of the hydrologic reporting areas in the Northern Great Plains and Rocky Mountain Coal Provinces (see report cover). Area 52 includes parts of Wyoming, Colorado, Utah, and Idaho. This report provides the background for the more detailed site-specific studies that will be needed by a mining-permit applicant to satisfy requirements of the Act.

Wyoming, Colorado, and Utah have established State programs and have been granted authority from the Office of Surface Mining to enforce the Surface Mining Control and Reclamation Act within their States. No surface mining of coal is currently (1983) being done in Idaho, and a State program has therefore not been established.

Figure 1.0-1 Potential impacts of mining on aquifers and streams. 


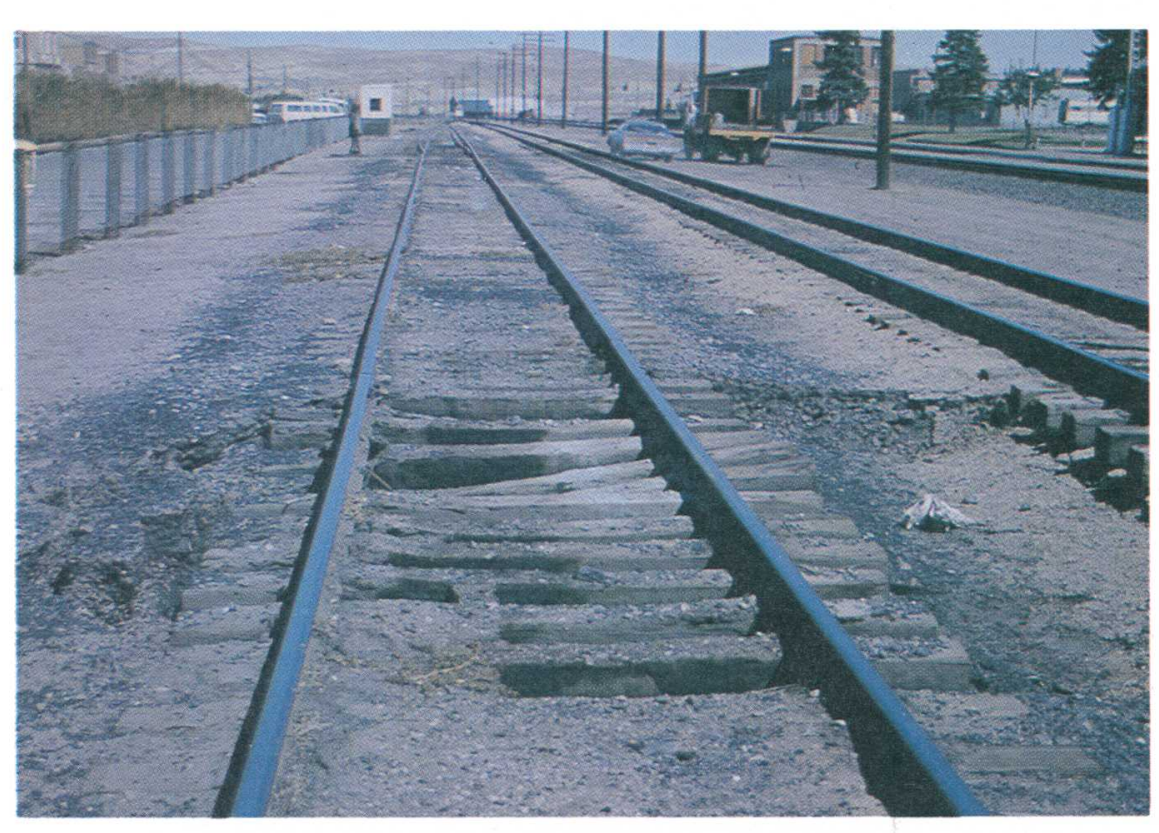

Figure 1.0-2 Subsidence due to underground mining can be aggravated by fluctuating ground-water levels. Photograp

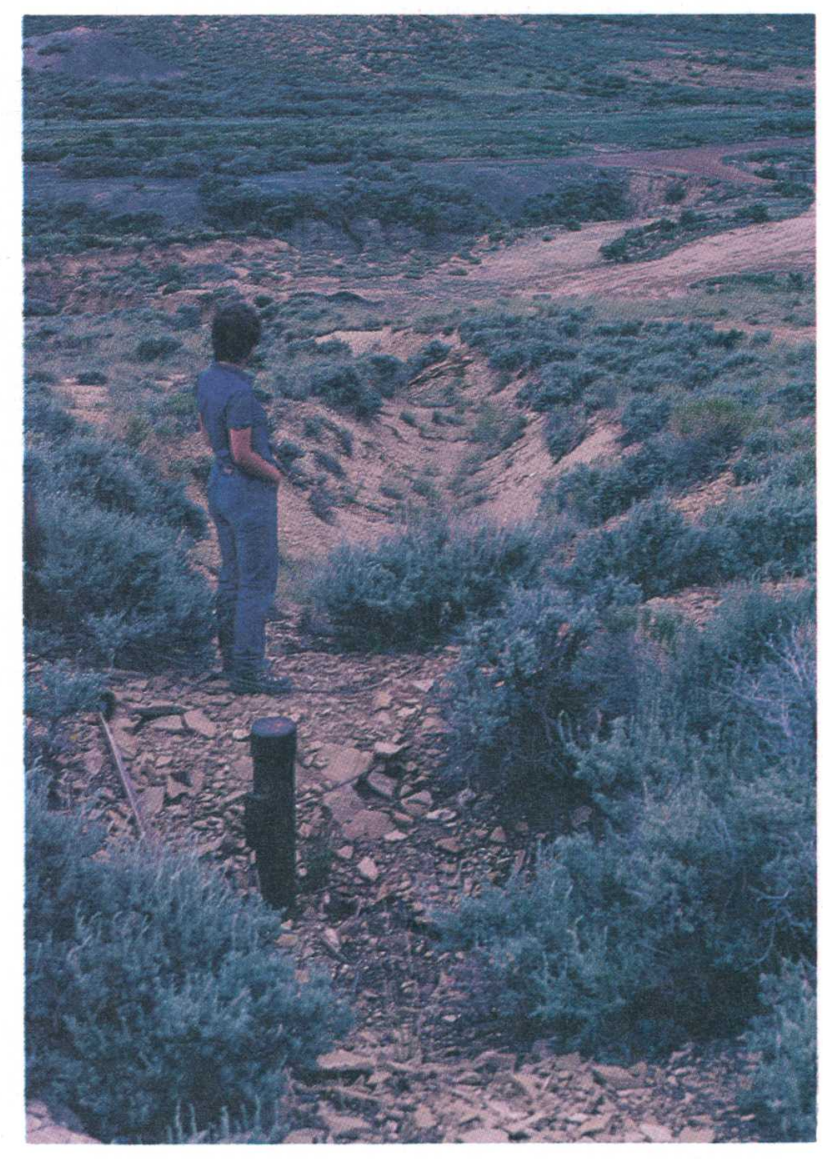

Figure 1.0-3 Dewatering of coal mines, as shown by is well near Superior, Wyoming, can contrib
to the erosion of ephemeral tributaries.

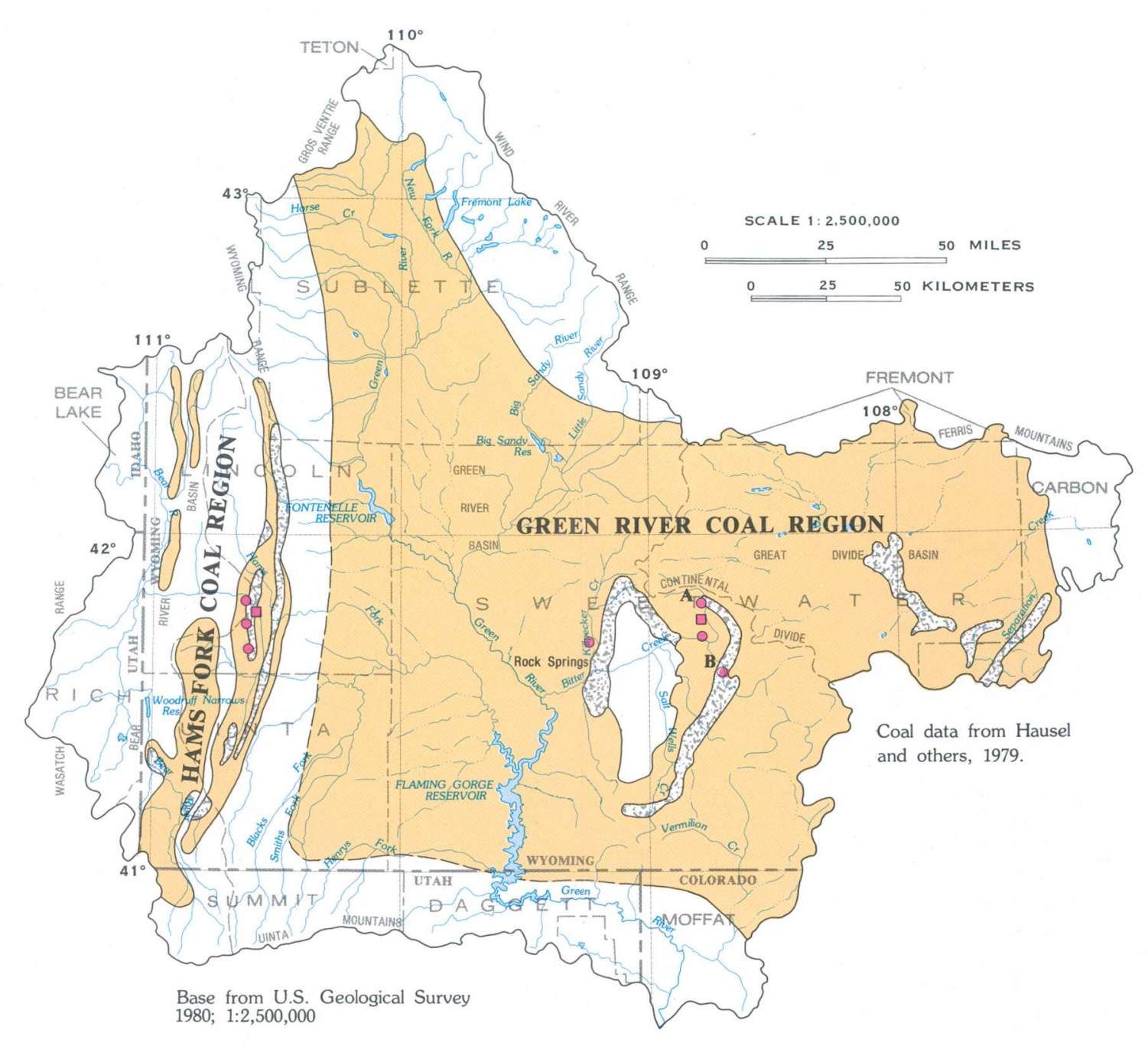

EXPLANATION

AREA UNDERLAIN BY COAL-BEARING BEDS

AREA OF KNOWN THICK OR ABUNDANT COAL

- COAL-FIRED POWERPLANT

- active coal mine

A JIM BRIDGER COAL MINE

B BLACK BUTTES MINE

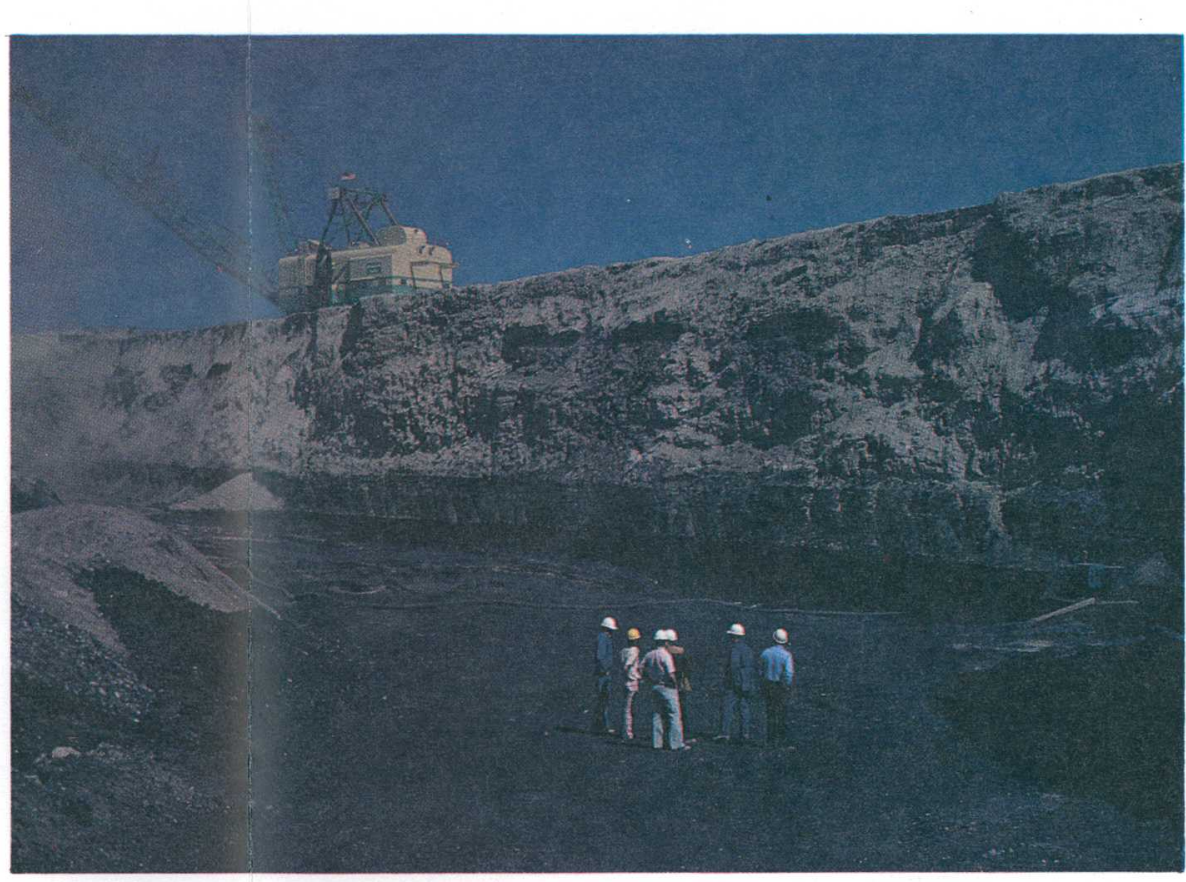

Figure 1.0-5 Jim Bridger Coal Mine (A on map).

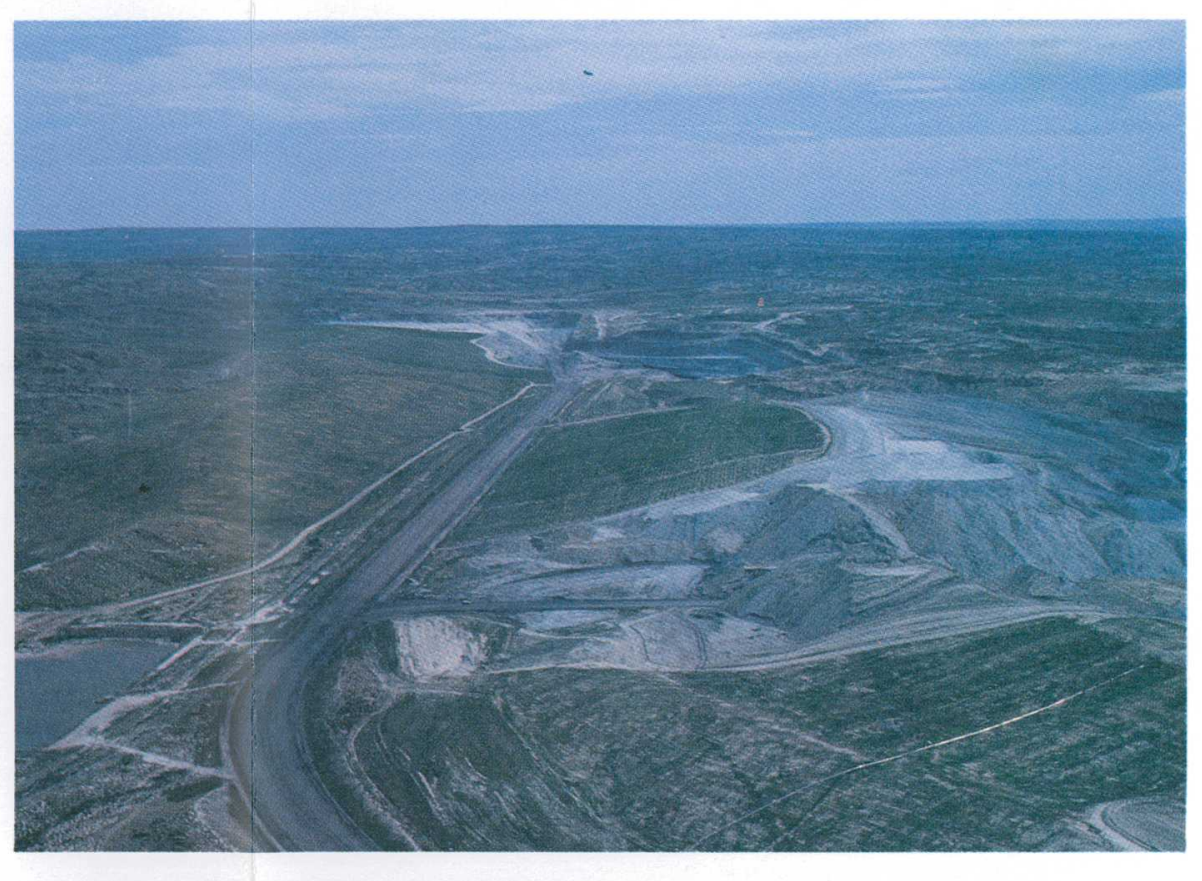

Figure 1.0-6 Reclamation of strip-mined lands in arid regions can be difficult, greatest aids revegetation. Photograph is of the Black Buttes Mine
(B on map). 


\subsection{GENERAL FEATURES \\ 2.1 Drainage and Landforms}

\section{Green River is Major Stream in Area 52}

\section{The Green River drains 72 percent of the area, streams in the Great Divide Basin drain 16 percent, and the Bear River drains 12 percent.}

Area 52 covers approximately 23,870 square miles. About 21,020 square miles of the area is in the Green River Basin, which includes the Great Divide Basin, a topographically closed area of 3,959 square miles. Area 52 also includes the upper part of the Bear River Basin with a drainage area of 2,840 square miles. The Green River is part of the Colorado River Basin; the Bear River is part of the Great Basin and flows into the Great Salt Lake.

The area is a high desert plateau that is flanked by higher mountain ranges. Altitudes range from 5,300 feet along the Green River at the southern end of the area to 13,785 feet at Gannett Peak in the Wind River Range. Some of the landforms. in the area are shown in figure 2.1-1.

There are more than 1,000 glacial lakes in headwater areas of streams along the west slope of the Wind River Range. There are also many lakes in the Uinta Mountains.
Numerous perennial streams originate in the mountain ranges.

The interior plains of the Green River Basin are characterized by shallow river valleys and scattered buttes. Ephemeral and intermittent streams originate in this area of treeless plains, mesas, and picturesque badlands. Active sand dunes are present in the central part of the basin. Altitudes of the plains are mainly between 6,500 and 7,500 feet.

The Great Divide Basin is a relatively shallow depression with isolated buttes, panlike depressions, and sparse vegetation. The Continental Divide is the hydrographic boundary separating the Great Divide Basin from the rest of the Green River Basin, but it is barely perceptible as a surface feature along much of its length. 


\subsection{GENERAL FEATURES--Continued \\ 2.2 Geology}

\section{Tertiary Rocks Underlie Most of Area 52}

\section{Wasatch, Green River, and Bridger Formations underlie most of the basins; most of the coal is in the Fort Union Formation.}

Most of the surface of Area 52 is underlain by Tertiary rocks of the Wasatch, Green River, Washakie, Browns Park, Battle Spring, and Bridger Formations (fig. 2.2-1). The Wasatch rocks are predominantly red and gray sandstone, which was deposited by coalescing streams, but include some coal beds. The rocks of the Green River Formation, formed from deposits in an ancient lake, are predominantly maristone (a shaly limestone), fine-grained sandstone, and oil shale. The Bridger rocks are drab olive sandstone and shale and include much volcanic ash.

Older rocks crop out in the mountains, in the Rock Springs uplift, and in the Overthrust belt (fig. 2.2-2). Rocks from Precambrian age (the oldest) to Holocene Age (the youngest) are exposed in the area. Alluvial deposits of sand and gravel border most of the principal streams; gravel blankets some terraces substantially above stream levels. Glacial drift of sand, gravel and till form an apron along the foot of the Wind River Range and part of the Uinta Mountains. Sand dunes form a line about 35 miles long across the western part of the Great Divide Basin (fig. 2.2-3).

The geologic map shows the distribution of rocks that crop out in Area 52. Because of the scale of the map and complexity of the geology, the map units are grouped by age. For example, the youngest deposits (Qa and Qp on map) include alluvium along streams, dune sand, terrace gravel, and glacial drift.

The correlation of the formations comprising the units shown on the map can be complex, as shown on the stratigraphic columns (table 2.2-1). Some of the formations on the column do not crop out within the area. More detailed mapping of the various parts of the area at larger scales is available from many sources. Some of the more comprehensive sources are Welder (1968), Welder and McGreevy (1966), and Lines and Glass (1975).

Most of the economically important coal in the area is in the Cretaceous Mesaverde Group, the partly equivalent Adaville Formation, the Lance Formation, the Evanston Formation (Cretaceous and Tertiary), the Tertiary Fort Union and Wasatch Formations. Many units produce some gas and oil, but the Nugget and Frontier Formations are perhaps the most productive. The Green River Formation includes vast amounts of oil shale and the largest bedded trona deposits in the world.
Table 2.2-1 Stratigraphic column of Area 52.

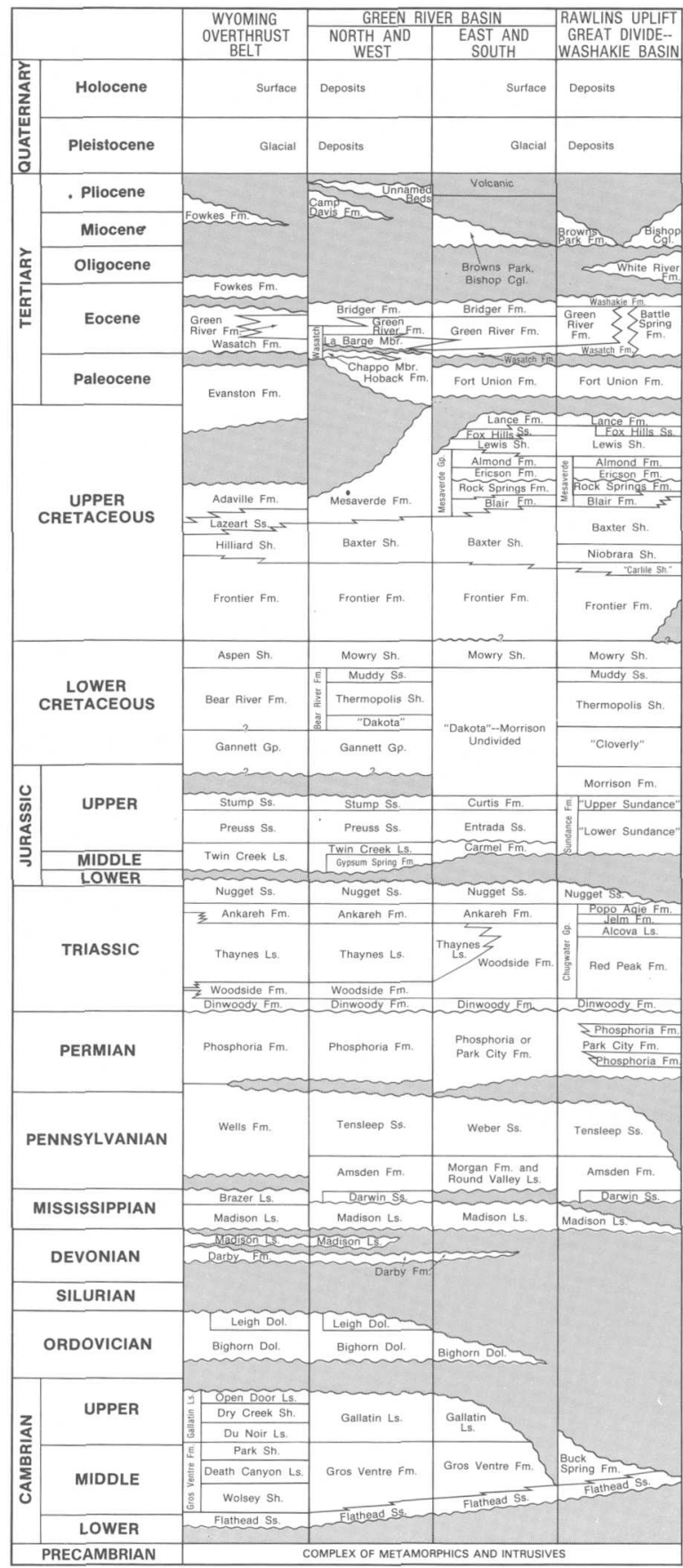

Modified from Wyoming Geological Association, (1969) 


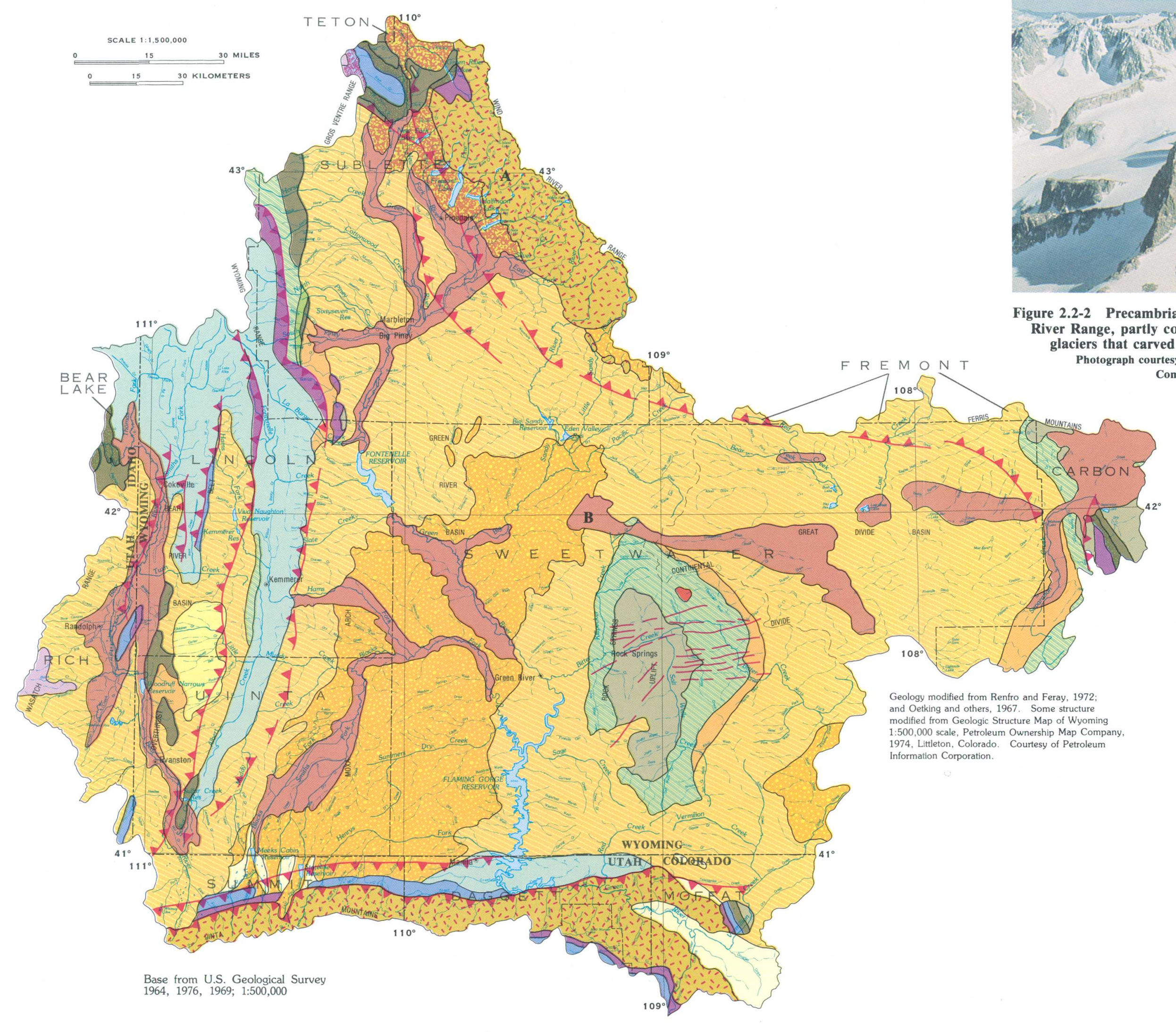

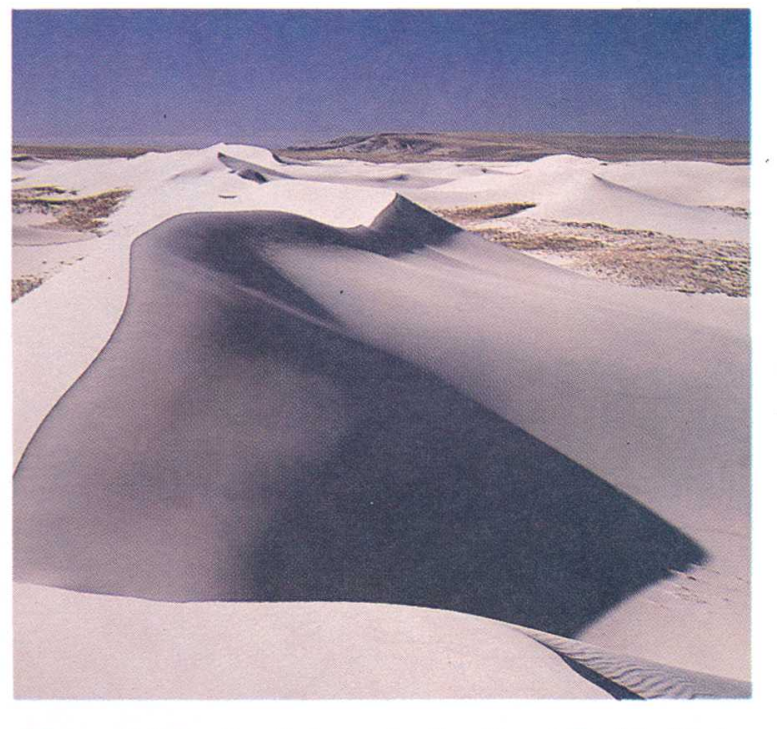
Figure 2.2-3 Sand dunes in the Great Divide Basin
(near B on map). Photograph courtesy of the Wyoming
Game and Fish Depertment.

EXPLANATION

QUATERNARY

SURFACE DEPOSITS Alluvium, terrace deposits, sand dunes, lakebeds GLACIAL DEPOSITS (PLEISTOCENE)

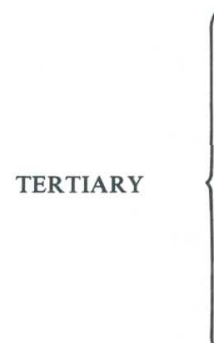

$\square \quad$ TERTIARY ROCKS

volCaNIC ROCKS

$\square$ NORTH PARK, BROWNS PARK, BISHOP FORMATIONS

BRIDGER AND WASHAKIE FORMATIONS

WASATCH, GREEN RIVER, BATTLE SPRING FORMATIONS FORT UNION FORMATION

$\begin{cases}\square & \text { MESOZOIC ROCKS } \\ \square & \text { LANCE FORMATION, LEWIS SHALE, MESAVERDE GROUP }\end{cases}$

MESozor

HILLIARD AND BAXTER SHALES, FRONTIER SANDSTONE

MOWRY SHALE, THERMOPOLIS SHALE

CLOVERLY-MORRISON, STUMP, PREUSS, TWIN CREEK
SUNDANCE, GYPSUM SPRING, NUGGET FORMATIONS

CHUGWATER, ANKAREH, THAYNES, DINWOODY,
WOODSDE FORMATIONS

PALEOZOIC ROCKS

PALEozoic

PHOSPHORIA, GOOSE EGG, WELLS, TENSLEEP
AMSDEN, MADISON FORMATIONS

DARBY FORMATION

BIGHORN, GALLATIN, GROS VENTRE, FLATHEAD FORMATIONS

PRECAMBRIAN

\section{$\therefore$ PRECAMBRIAN ROCKS}

CONTACT FAULT

THRUST FAULT Sawteeth on overthrust plate

A PRECAMBRIAN GRANITE PEAKS

B SAND DUNES 


\title{
2.0 GENERAL FEATURES--Continued 2.3 Structure and Stratigraphy
}

\section{Structural Deformation Helped Determine the Kinds of Rocks Present}

\author{
Through the ages, Area 52 has been subjected to intense deformation resulting \\ in deep sediment-filled basins separated by uplifts and faults.
}

Six major structural units comprise the area: the Great Divide Basin, the Rock Springs uplift, the Wind River Mountains, the Uinta Mountains, the Green River Basin, and the Overthrust belt (fig. 2.3-1). The contours on the map are similar to those on a topographic map except that these structural contours are drawn to represent the top of the Cloverly or Dakota Formations-geologic units that are deeply buried in almost all of the area.

The basins are deep troughs in which as much as 30,000 feet of sediments have accumulated. The Rock Springs uplift is a north-trending dome cut by numerous faults. The Wind River and Uinta Mountains are masses of Precambrian igneous and metamorphic rocks that have been thrust up along steep faults over the younger sediments in the Green River Basin.

The compressional forces that thrust these mountains over the basin sediments also caused failure of the rocks in the Overthrust belt, forming a complex series of north-trending faults that allowed older rocks to override the basin sediments to the east. These faults are repeated many times causing an arrangement of the rocks resembling shingles on a roof (an imbricate structure in geologic terms).

The development of the structural features strongly affected the nature of the rocks deposited in the area. Before intense deformation began in Late Cretaceous time (about 100 million years ago), the area had been subject to repeated invasions by sea water. When it was inundated, marine deposits such as limestone, dolomite and shale were laid down. When the seas withdrew, shore deposits of wind-blown and beach sand accumulated.

When the area rose in Late Cretaceous time, the seas withdrew and a poorly drained terrain developed where ponds, swamps, and lagoons abounded. On this terrain, lush vegetation grew, fell, and was preserved in the acidic waters. As this vegetative matter accumulated, it was buried, compacted, and became coal in the Mesaverde and younger formations. As uplift and faulting intensified, the mountains became a source of sand and gravel that were deposited along the streams crossing the basins.

Uplift intensified further and drainage from the basins was disrupted. Lake Gosiute formed in the basins (Bradley, 1964, p. A36). Because the lake had no outlet, evaporation concentrated the salts in its water. Despite these salt concentrations, aquatic life thrived in the lake, probably in a comparatively fresh surface layer. As the aquatic life perished, much of it was preserved, was buried in lake sediment, and formed the abundant, well preserved fish fossils for which the lake sediments (the Green River Formation) are famous (fig. 2.3-2). Much was chemically altered and incorporated as organic matter in the lake sediments--forming oil shale. The earth movements also triggered volcanic activity; volcanic ash beds are abundant in the lake sediments.

Eventually, streams cut through the Uinta Mountains and restored external drainage to the Green River Basin though not to the Great Divide Basin. At first, drainage was sluggish and meandering streams deposited lenses of sand and clay interbedded with much volcanic ash. As gradients steepened with downcutting, streams eroded the sediments. Glaciers developed on the high mountains. Torrential flows from the glaciers carried sand and gravel out onto the foot of the mountains and onto the flood plains of the major streams. Remnants of the glaciers persist today, but the water no longer carries such a large load of sediment. Many of the gravel deposits have been eroded through; the streams have cut down through the gravel, leaving upland terrace deposits.

The intensity of structural deformation can be seen in the Flaming Gorge where the Green River has cut through steeply inclined and faulted rocks on the north side of the Uinta Mountains (fig. 2.3-3). The gorge and downstream canyons provide spectacular scenery and the site for the dam forming Flaming Gorge Reservoir. 


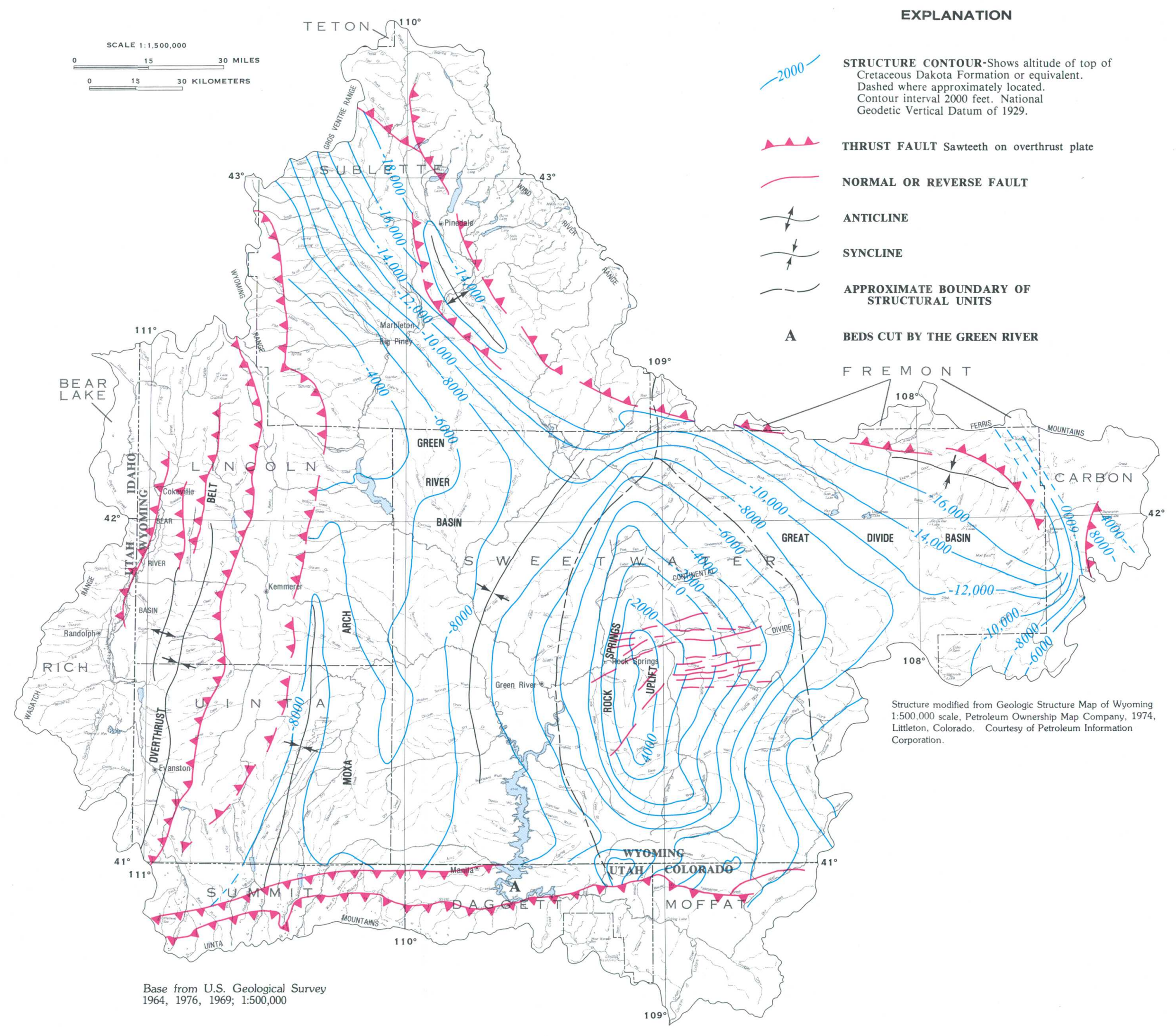

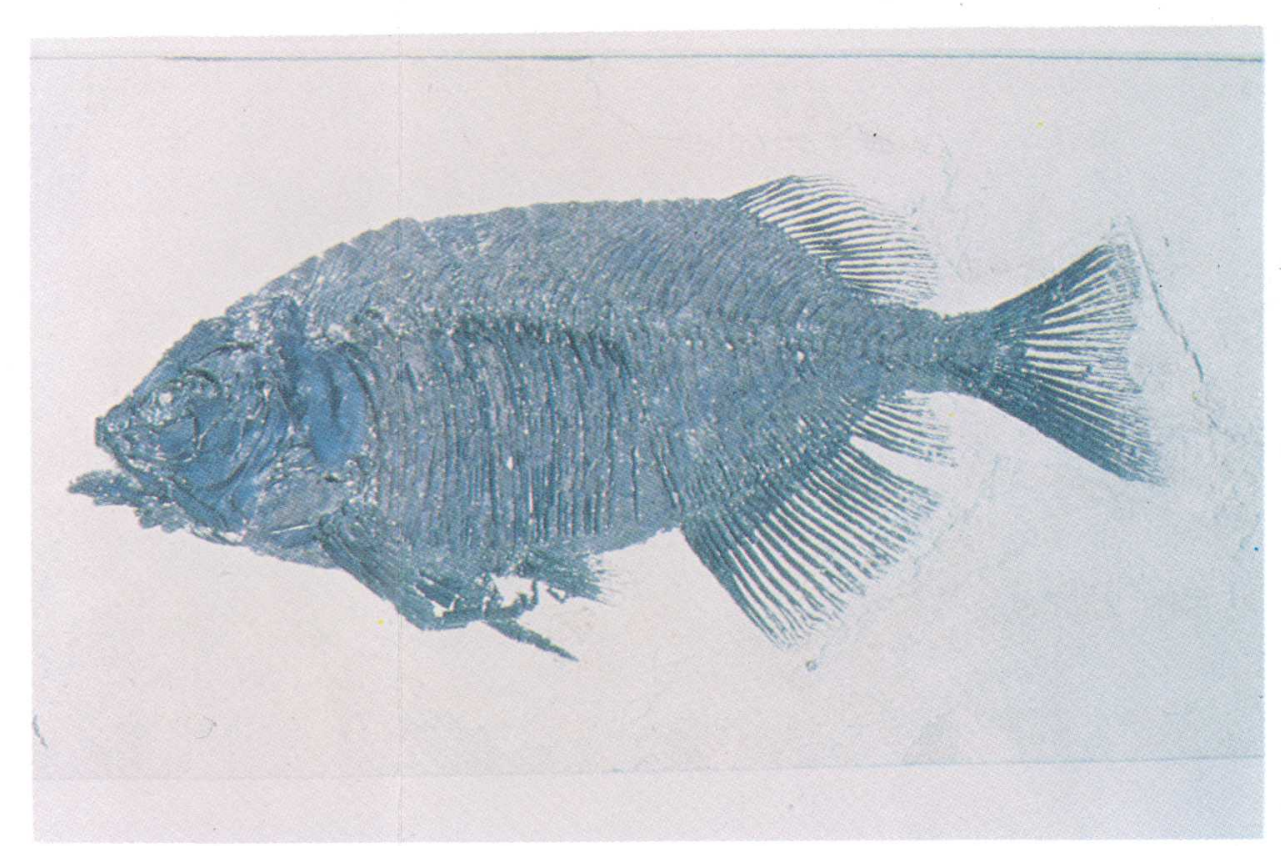

Figure 2.3-2 Fossil fish from the Green River Formation

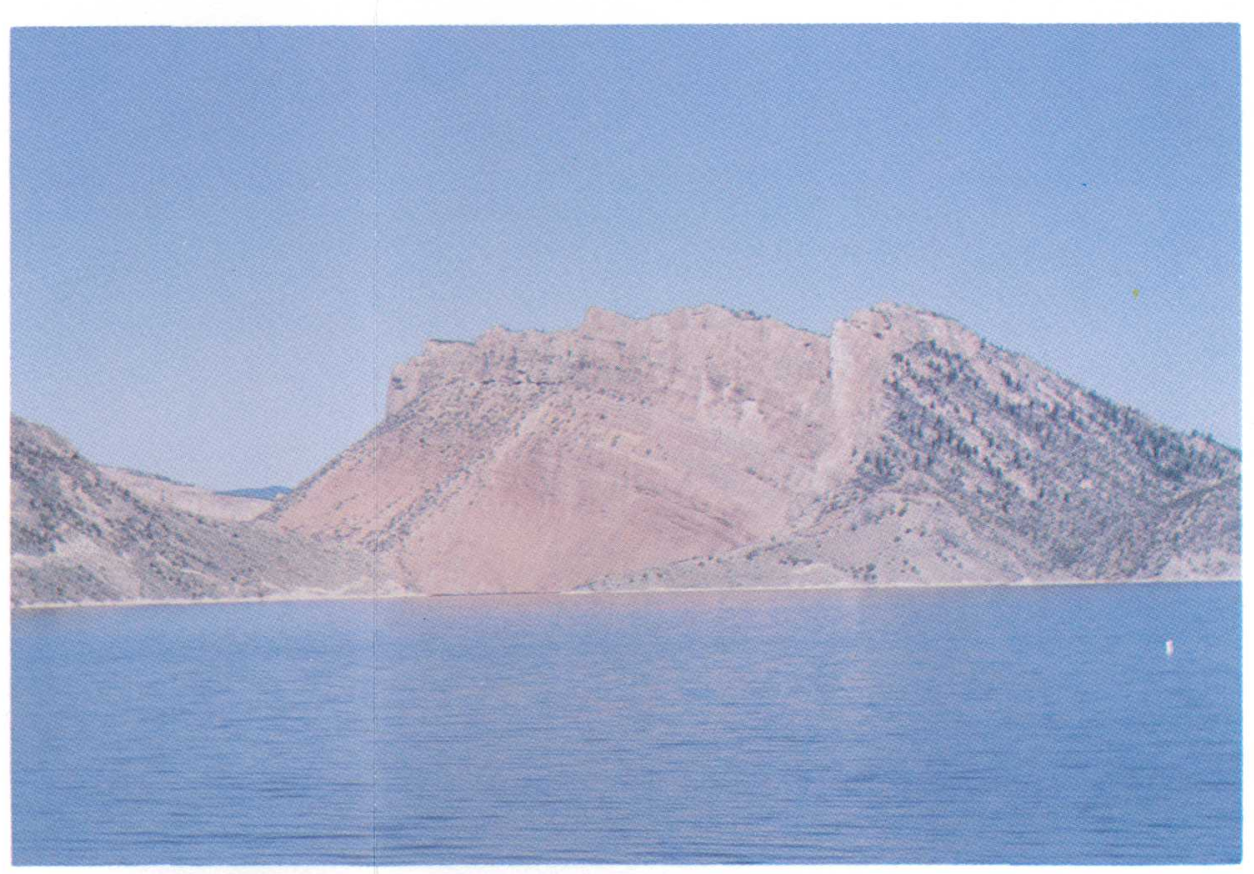

Figure 2.3-3 Contorted beds cut by the Green River form the Flaming Gorge (near A on map). 


\subsection{GENERAL FEATURES--Continued 2.4 Soils}

\section{Differences in Soils are Mainly Due to Origin and Climatic Conditions}

Soils developing from shales and sandstones comprise the largest part in Area 52.

Soils in this area are classified into five broad groups based primarily on differences in geologic origin and climatic conditions. These soil groups are mountain soils, fan and terrace soils, upland soils, flood-plain soils, and sand-dune soils. A generalized map of the soils in the area is shown in figure 2.4-1.

The mountain soils are on rolling to steep mountainous landscapes and are formed on residual and transported material from igneous and sedimentary rocks. These soils are shallow to deep, well drained, and moderately permeable. Runoff potential is moderately low to high, and soil erodibility ranges from low to moderate.

The fan and terrace soils are developing on broad, nearly level to sloping outwash fans and terraces that are composed of gravelly to stony alluvium and glacial deposits. These soils are deep, well drained, and moderately to rapidly permeable. Runoff potential is low to moderately high, and soil erodibility varies from low to moderate.

Upland soils are present in much of the area (fig. 2.4-2) and are located in the nearly level to rolling terrain dissected by the flood plain of the Bear and Green Rivers and tributaries. These soils are developing in residuum of shales and sandstones that contain variable amounts of soluble salts. Most of the upland soils are moderately deep, well drained, and moderately permeable. Runoff potential is low to high, and soil erodibility generally is moderate. Most of the coal deposits are associated with this soil group; locally, mined-land revegetation efforts may be seriously hampered because of high salinity and alkalinity conditions in these soils.

The flood-plain soils are present on flood plains, playas, and upland drainage channels. These soils are formed in alluvium, which is derived primarily from weathered shales and sandstones that contain varying amounts of soluble salts. These soils are deep, poorly to moderately drained, and moderately permeable. Runoff potential is moderately high to high, and soil erodibility is moderate. Areas with these soils that have an adequate water supply are frequently used for growing hay (fig. 2.4-3).

Sand-dune soils developed in low hummocky dunes, which consist of wind-blown sands. These soils are deep, well drained, and highly permeable. Runoff potential and soil erodibility by fluvial processes are low.

Information on soils is important to the planning of mined-land reclamation. A detailed description of soils is required by the regulatory agencies prior to the granting of a mine permit. Except for mines that have already been granted permits, detailed soil surveys have not been completed in most of the area. Additional soil information is available from Heil and others (1977) for Colorado, U.S. Soil Conservation Service (1973a, 1973b) for Idaho and Colorado, Young and Singleton (1977) for Wyoming, and from offices of the U.S. Soil Conservation Service and the U.S. Bureau of Land Management. 

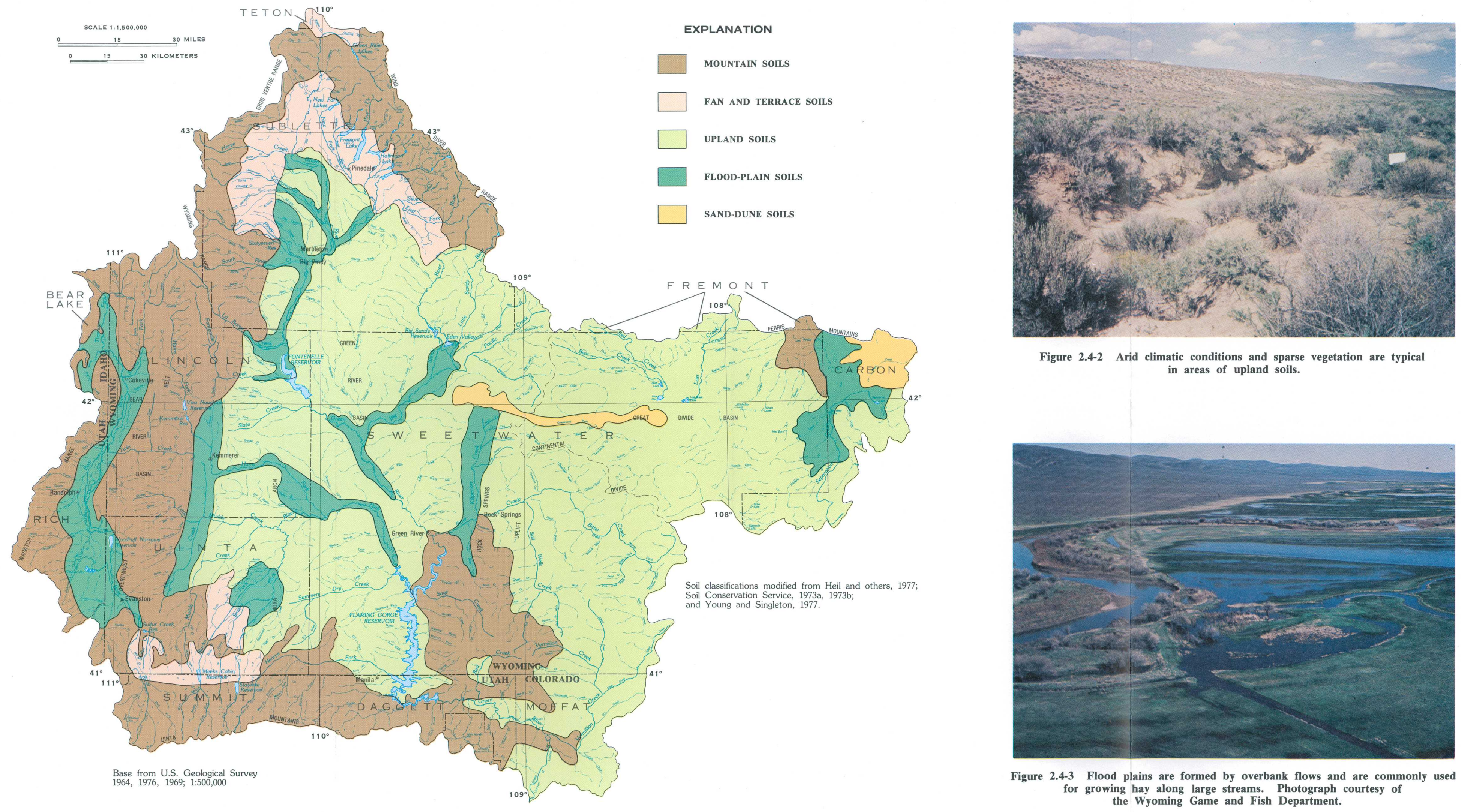

Figure 2.4-2 Arid climatic conditions and sparse vegetation are typical in areas of upland soibs.

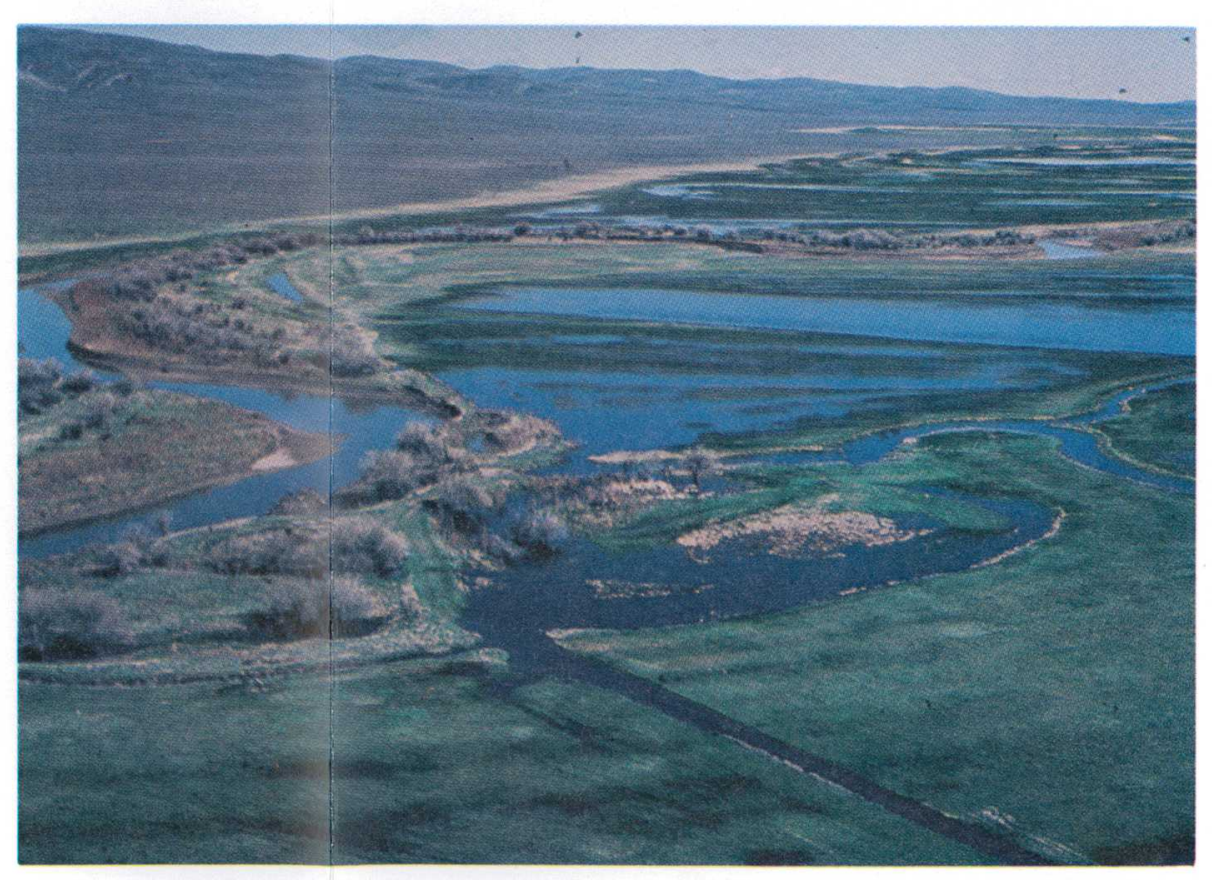
Figure 2.4-3 Flood plains are formed by overbank flows and are commonly used
for growing hay along large streams. Photograph courtesy of the Wyoming Game and Fish Department. 


\title{
2.0 GENERAL FEATURES--Continued 2.5 Climate
}

\section{Precipitation Related to Altitude}

\author{
Average precipitation in the high mountains exceeds 30 inches per year; the \\ lower plains receive 7 to 10 inches.
}

Annual precipitation is related to altitude, with the mountains receiving more precipitation than the lower plains (fig. 2.5-1). Westerly winds prevail in the area, and the air mass generally is from the Pacific Ocean. Coastal mountain ranges cause much of the moisture to precipitate before reaching the area.

Most wintertime precipitation is in the form of snow. Cold airmass movements from the north occasionally move into the area, wedging under the warmer surface air, forcing it upward and causing snow. The cold temperatures allow much of the snow to be retained, especially in the mountains. In the plains, much snow is sublimated by the wind and sun, and retention occurs mainly as drifts in draws and shaded areas (fig. 2.5-2).

Summertime precipitation occurs as light rain and occasional intense thunderstorms that generally move in an easterly direction. The warming of the atmosphere in the spring increases its moisture-carrying capacity, causing relatively large amounts of precipitation during May and June (fig. 2.5-3). As summer progresses and the atmosphere warms, there is more moisture available for precipitation, but the cumulus-type clouds are formed much higher above the ground. Precipitation from these clouds has a relatively long path through dry air and much of it evaporates before reaching the ground.

The amount of precipitation that occurs from year to year is highly variable. The weather station at Kendall
(1929-76) recorded a high of 26.72 inches during 1945 and a low of 7.48 inches during 1974. The station at the Rock Springs airport (1932-81) recorded a high of 14.54 inches during 1965 and a low of 4.54 inches during 1974.

Streamflow in the area is correlated with precipitation. Most of the perennial streams originate in the mountains, which receive larger amounts of precipitation. Most of the runoff occurs during the spring and early summer as a result of snowmelt.

Normal air temperature is lowest during January and highest during July. Soil temperature at a depth of 6 feet varies much less than air temperature and lags behind the air temperature by about 1 month.

Evapotranspiration is greatest during July, but continues to be significant well into the fall because of the warm soil temperature. Clear, sunny skies are present about 65 percent of the available daylight hours on an annual basis, ranging from 50 to 55 percent of possible during winter to 75 to 80 percent during late summer.

The foregoing description of climate is based on a report prepared by J. D. Alyea (1980). Climatological data are published monthly by the National Oceanic and Atmospheric Administration, National Climatic Center, Asheville, North Carolina. 

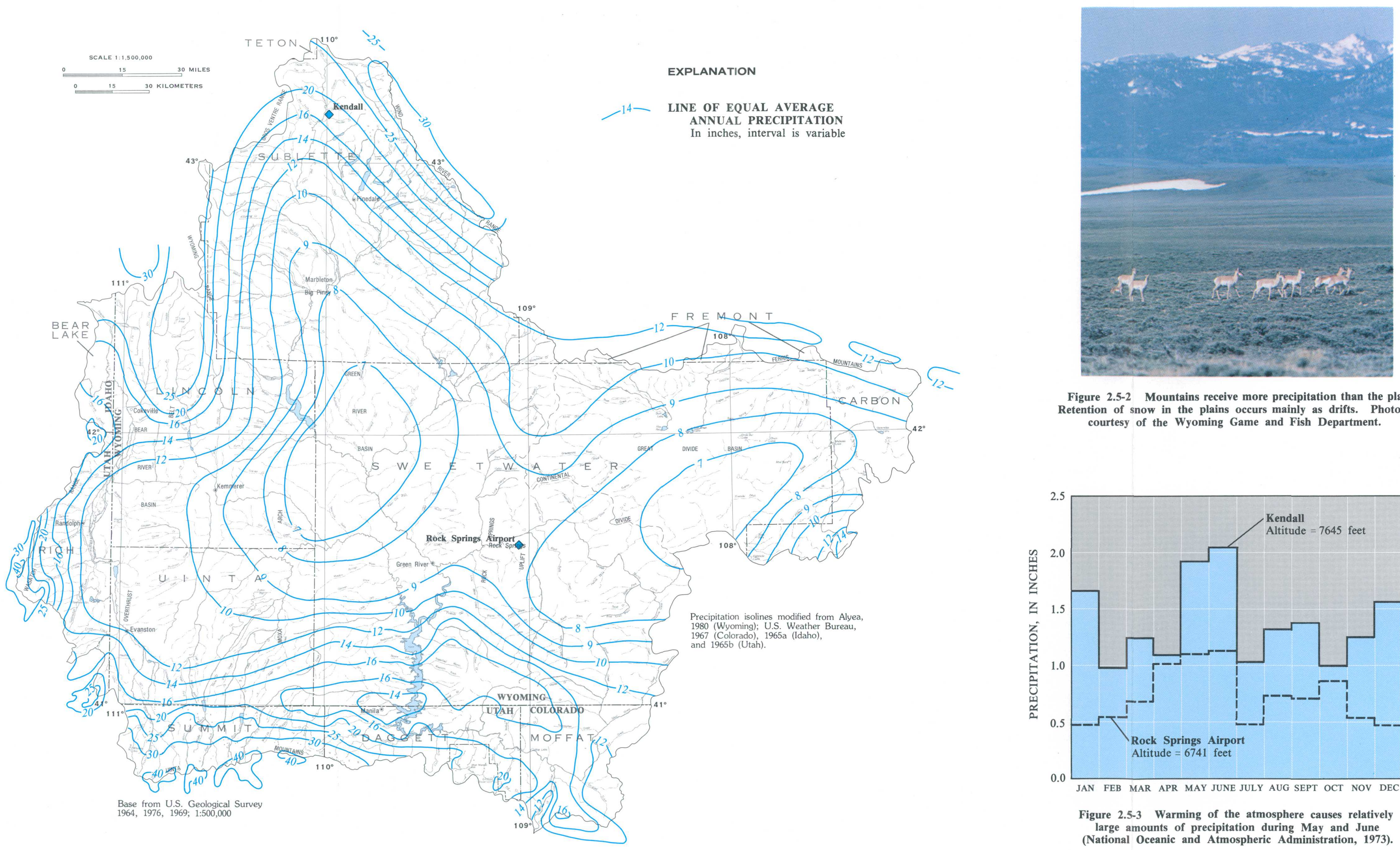

Figure 2.5-2 Mountains receive more precipitation than the plains. courtesy of the Wyoming Game and Fish Department.
.

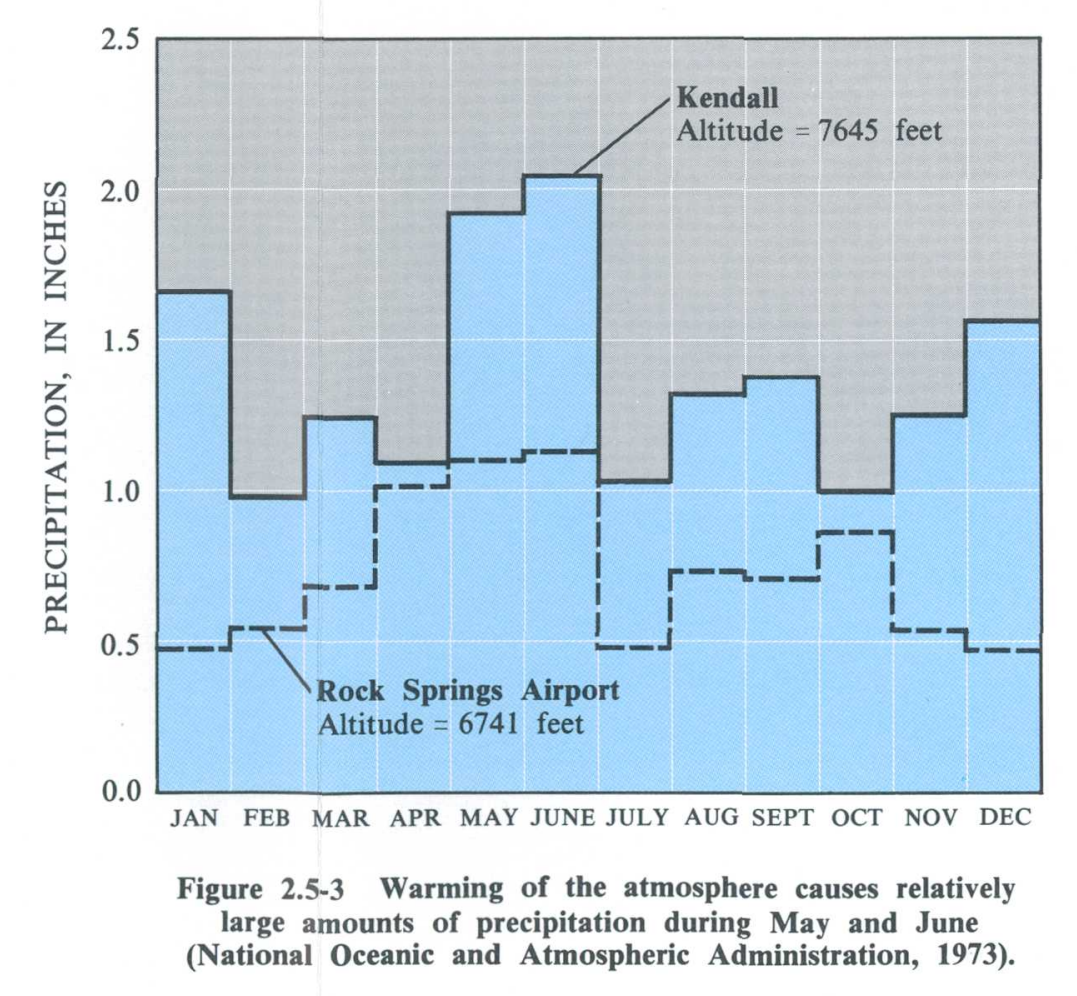




\title{
2.0 GENERAL FEATURES--Continued 2.6 Vegetation
}

\section{Sagebrush, Grasses, and Shrubs Predominate in Most of the Area}

\author{
The mountainous fringes of the area are covered by forests.
}

The predominance of sagebrush, grasses, and shrubs in Area 52 is evident in figure 2.6-1. Common plants in the plains of the area are big sagebrush, thickspike wheatgrass, Indian ricegrass, bluebunch wheatgrass, Sandberg bluegrass, and winterfat (Young and Singleton, 1977, p. 2). Trees generally are absent in the plains, except cottonwoods along some stream channels and juniper and pinyon on some breaks and hills.

The vegetation in the plains often appears to be sparse, and the rate of productivity is small (figs. 2.6-2 and 2.6-3). Growth generally is determined by the soils and climatic factors, such as the small amount of precipitation and the short growing season (Rathjen and others, 1977, p. 2). Native rangeland in this area provides less than 0.2 animal-unit month per acre on the average (Rathjen and others, 1977, p. 33). This converts to approximately 50 acres per year to support one cow and calf pair.
The small rate of productivity also hampers revegetation of reclaimed mined lands. Pre-mining and postmining vegetative productivity, density, and species composition may be used to evaluate the success of the revegetation efforts (Wyoming Department of Environmental Quality, $1978,1981 \mathrm{a}$, and 1981b). Successful revegetation is desirable for control of erosion, aesthetic value, and forage.

The mountainous fringes of the area support forests (fig. 2.6-4). Aspen and ponderosa pine are common in the forests of the foothills. The forests at higher altitudes are dominated by Englemann spruce, Douglas fir, lodgepole pine, and alpine fir. Alpine meadows and areas devoid of vegetation are found above timberline. The Wyoming part of the Green River drainage has approximately 1,200,000 acres of forest; 370,000 acres have been classified as commercial forest (Heckathorn and others, 1976, p. 4-11).

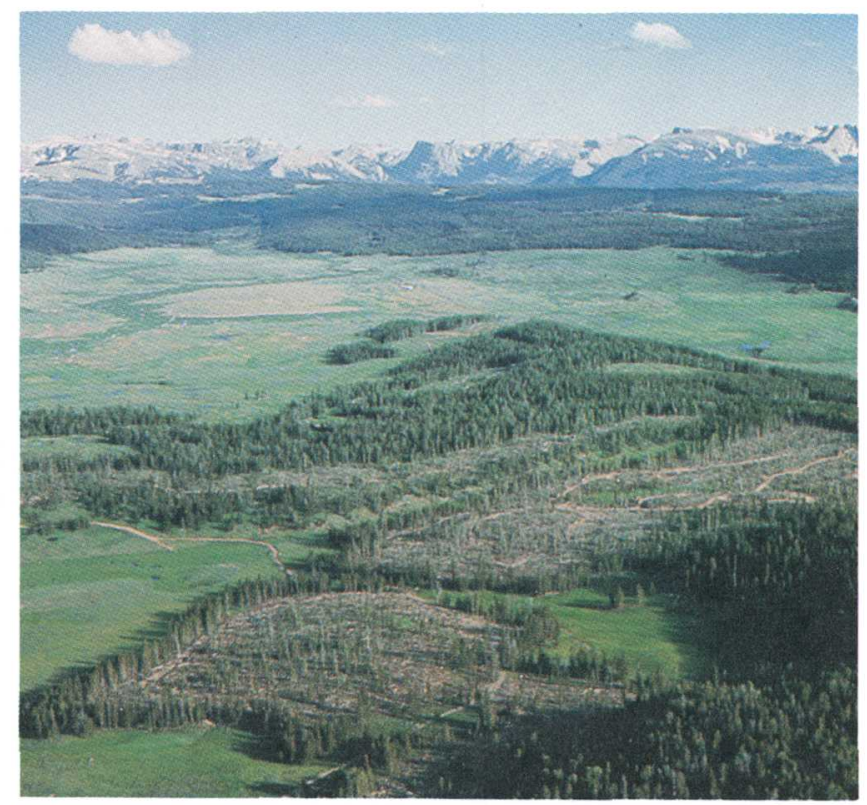

Figure 2.6-4 Sections of the mountain forest in the Wyoming Range (foreground) have been logged.

Photograph courtesy of the Wyoming Game and Fish Department. 

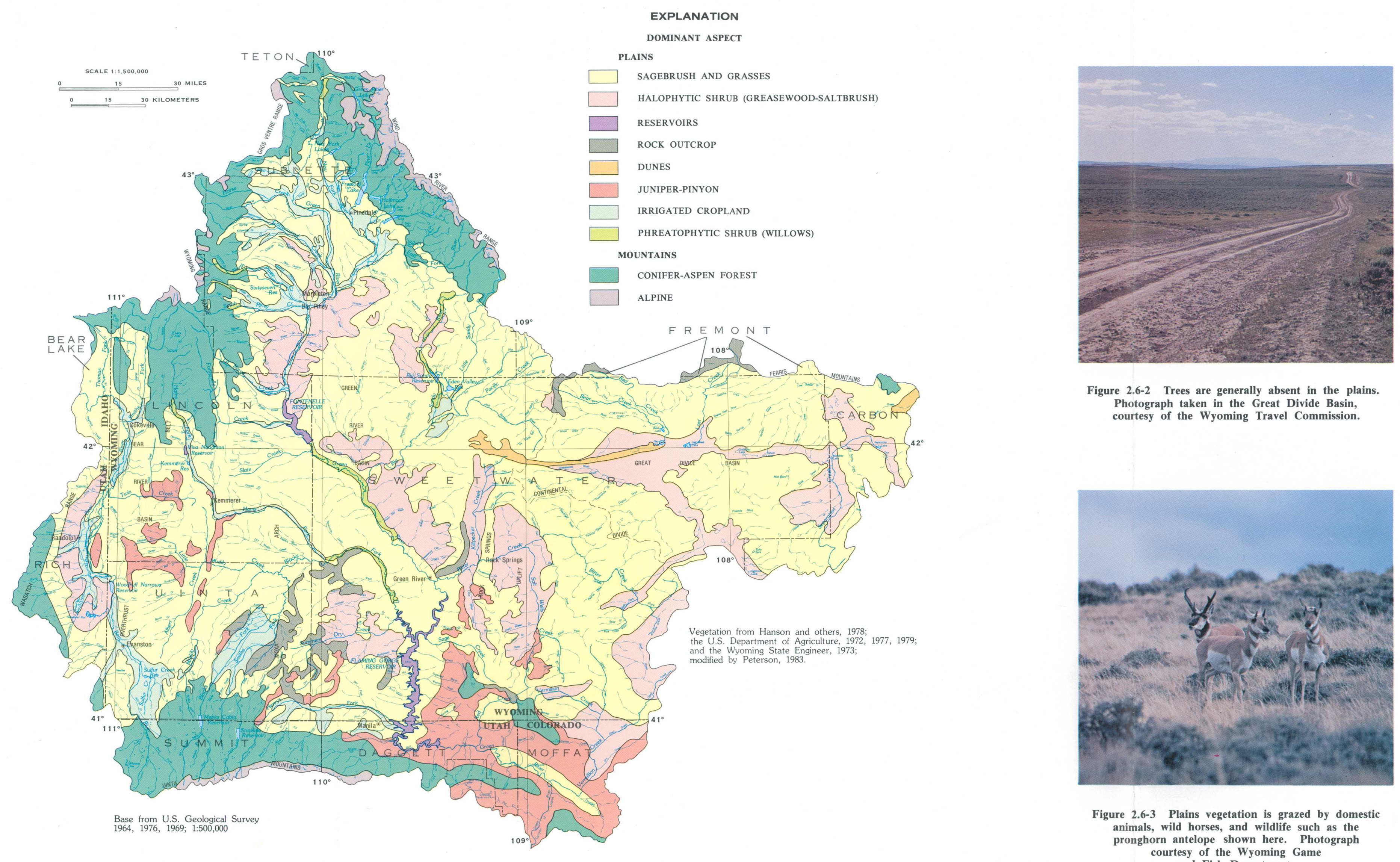

Figure 2.6-2 Trees are generally absent in the plains. Photograph taken in the Great Divide Basin,
courtesy of the Wyoming Travel Commission.

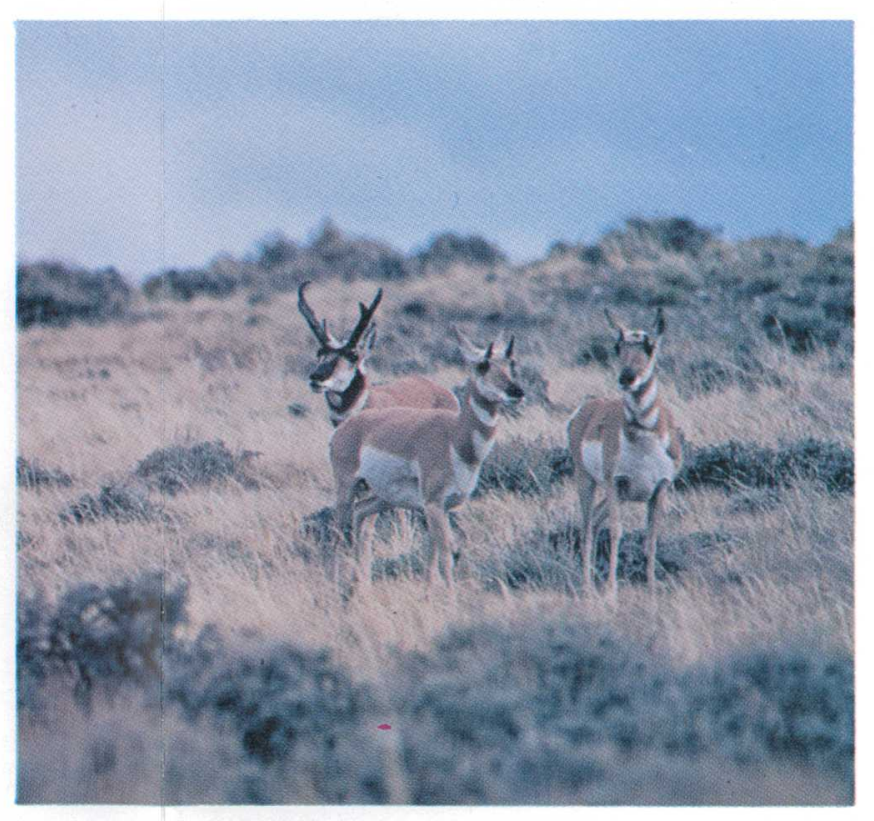

Figure 2.6-3 Plains vegetation is grazed by domestic animals, wild horses, and wildlife such as the
pronghorn antelope shown here. Photograph courtesy of the Wyoming Game
and Fish Department. 


\title{
3.0 RESOURCES AND ECONOMY

\author{
3.1 Land Use
}

\section{Livestock Grazing is the Most Common Land Use}

\author{
Active and abandoned coal mines occupy only a small fraction of the area; seven \\ surface mines are currently (1983) being operated, and two coal-fired \\ powerplants use coal mined from the area.
}

Grazing is the primary use of private land and public land leased from the Federal and State Governments. The ratio of cropland to rangeland is small, partly due to the need to irrigate crops. Nearly all of the cropland is used for hay and pasture production to help support livestock (Rathjen and others, 1977, p. 17). The ratio of rangeland to cropland in four counties of the area is shown in figure 3.1-1. The average size of the ranches in those four counties ranges from 1,185 acres in Lincoln County to 12,857 acres in Sweetwater County (Wyoming Department of Administration and Fiscal Control, 1981). The ranch sizes are a reflection of the sparse vegetation, since 50 or more acres of rangeland per year are necessary to support one cow and calf pair or five ewe and lamb pairs (fig. 3.1-2). Domestic and wild horses and wildlife also graze the rangeland. The total value of agricultural products (primarily livestock) sold in Lincoln, Sublette, Sweetwater, and Uinta Counties in 1978 exceeded $\$ 45$ million (Wyoming Department of Administration and Fiscal Control, 1981).

Active and abandoned coal mines occupy only a small fraction of the area. Seven surface mines are currently (1983) being operated, and two coalfired powerplants use coal mined from the area (fig. 3.1-1). Trona (sodium bicarbonate), which is used in the manufacture of glass, is mined from Area 52, as are many other minerals. Sawtimber, poles, posts, fuelwood, and Christmas trees are harvested from forests in the area; the value of these products harvested in 1970 exceeded $\$ 1$ million (Heckathorn and others, 1976, p. 18).

The amount of land used for urban areas and transportation is small because of the low population density of the area. Data from the Wyoming Department of Administration and Fiscal Control (1981) show that the total population of Lincoln, Uinta, Sublette, and Sweetwater Counties is approximately 70,000 people, and the largest city is Rock Springs, population 19,458 .

Increased mining of coal will cause changes in land uses, not only for the mines and coaltransportation facilities, but also related effects from the increased workforce, such as intensified use of recreational land. The most popular areas for backpacking, hiking, and many other forms of recreation are in the mountain ranges (fig. 3.1-3). Recreational opportunities also exist nearer to the potential mine sites, such as trout fishing on Flaming Gorge Reservoir. The waters of the Wyoming part of the Green River drainage provided more than 700,000 angler-days of use during 1979 (Phillips and others, 1981, p. 21). Antelope, deer, elk, and moose are plentiful in Area 52; and big game hunting is popular. Data from Tomlinsom (1981, p. 67-118) show that tourists and travelers spent a total of more than $\$ 40$ million during 1979 in Lincoln; Sublette, Sweetwater, and Uinta Counties. 


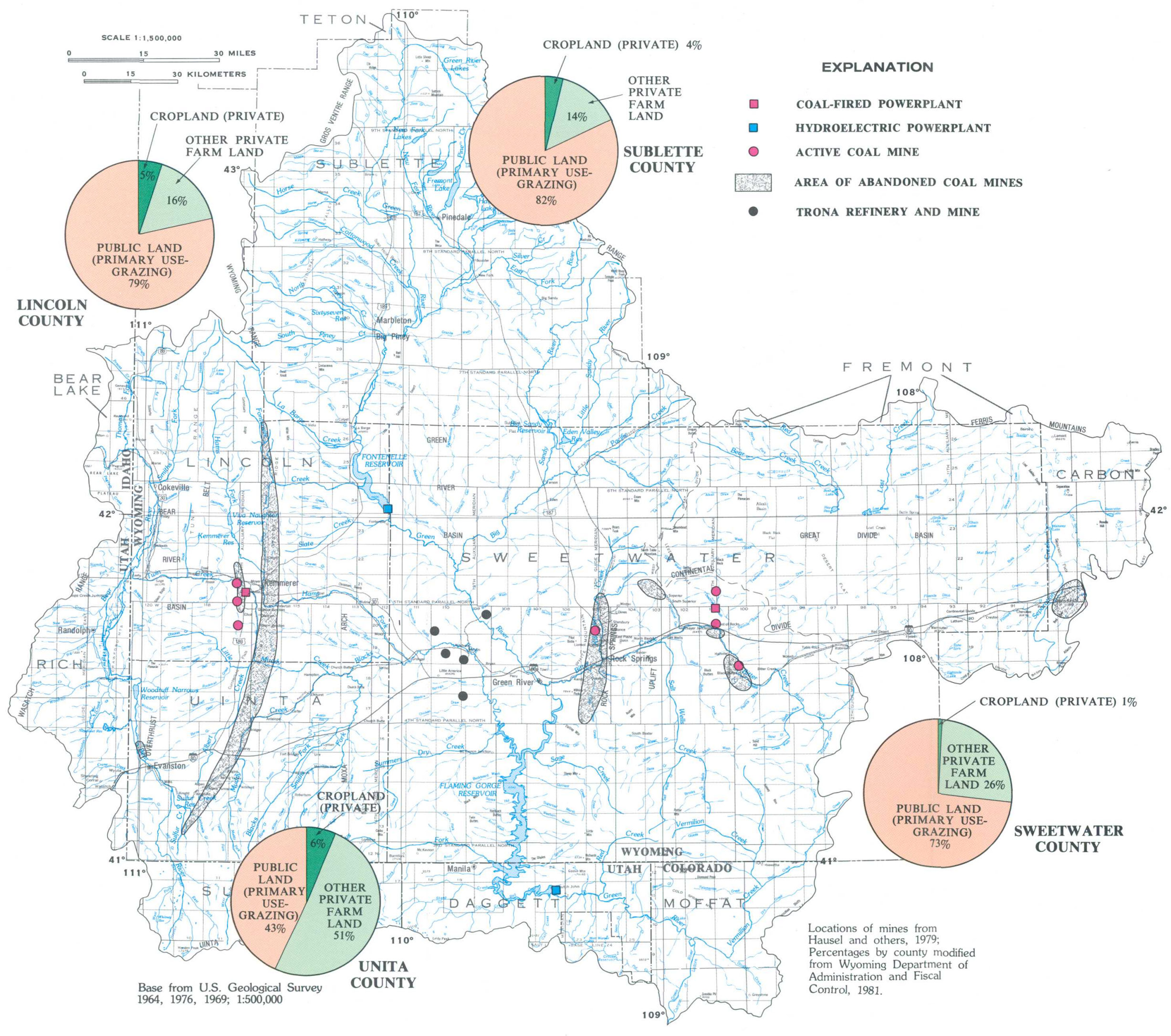

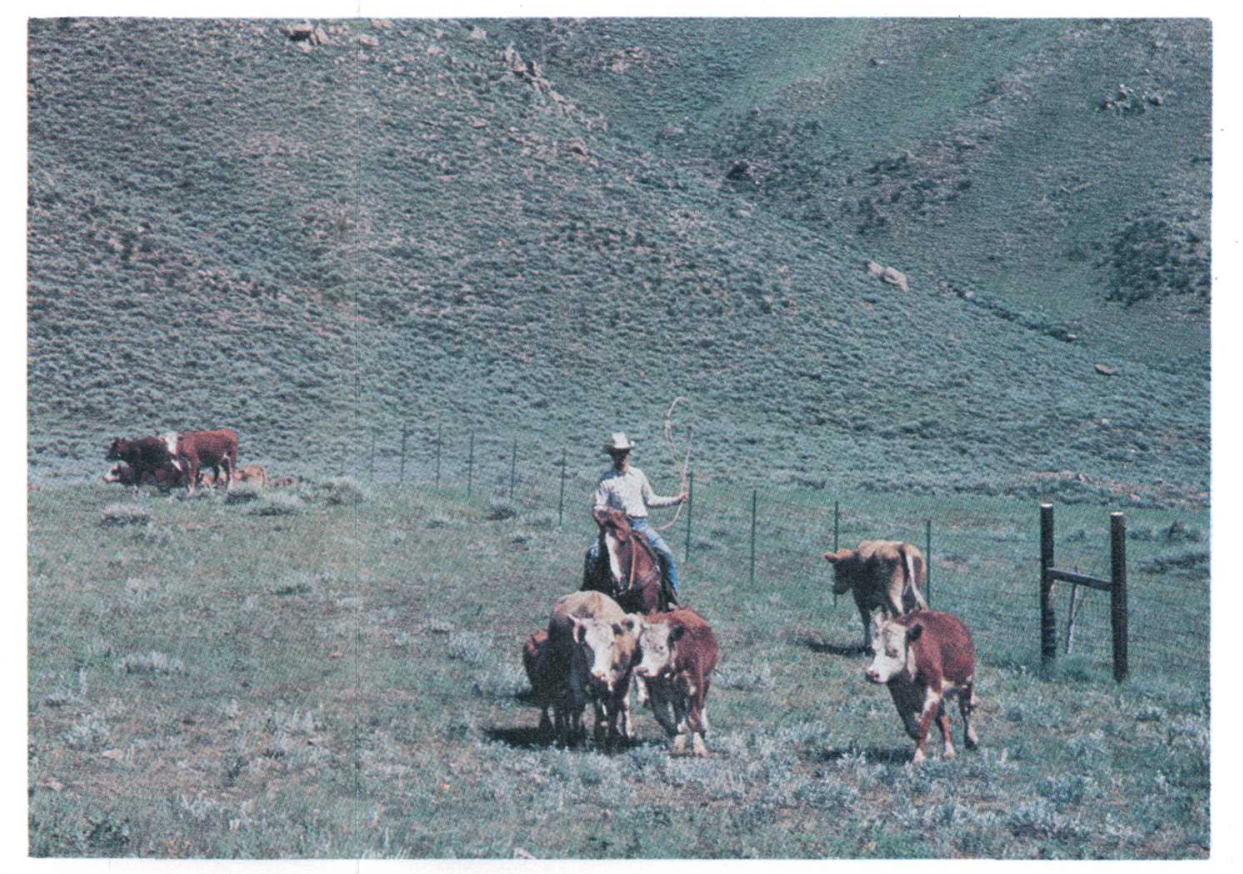

Figure 3.1-2 Cattle roundup and branding are still parts of ranching, which is a common land use throughout the area. Photograph courtesy of the

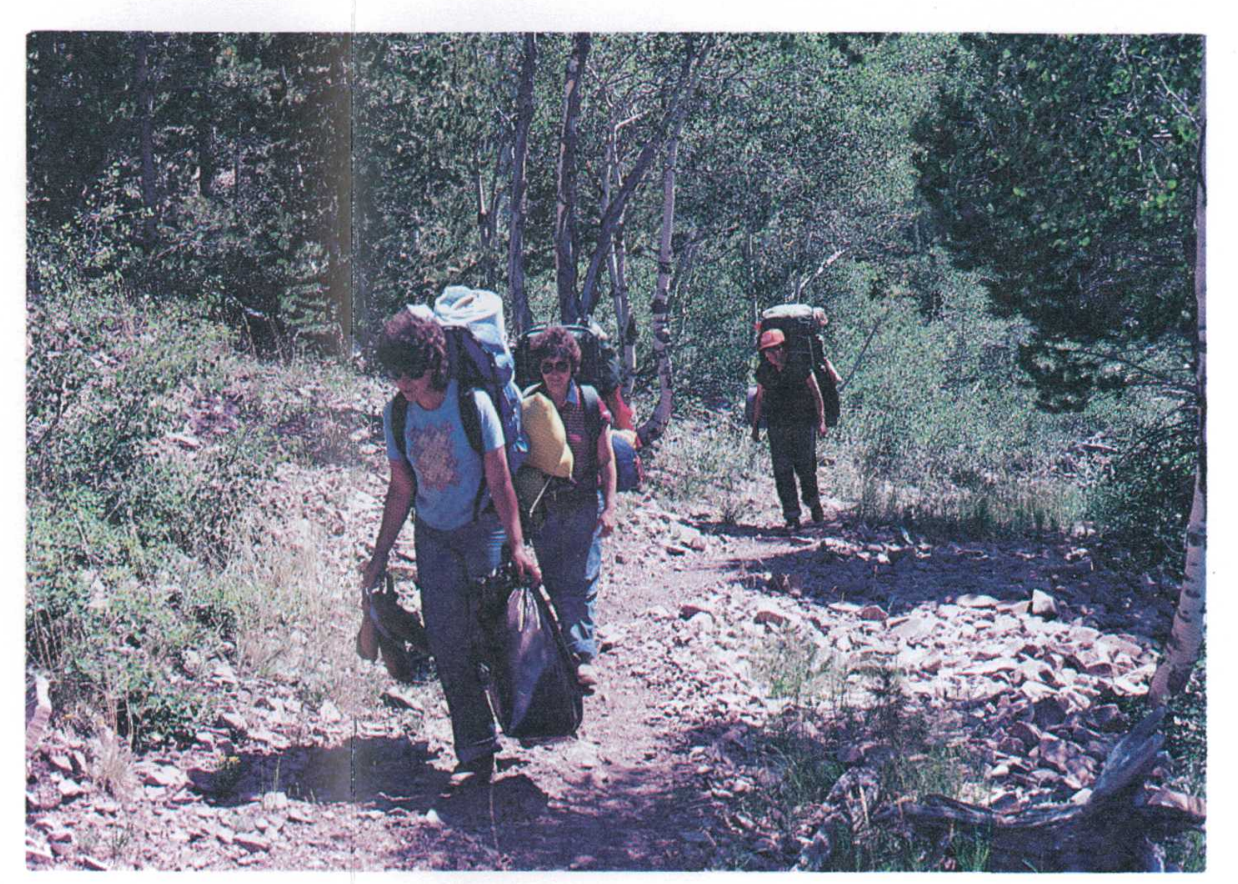

Figure 3.1-3 Backpacking. 


\title{
3.0 RESOURCES AND ECONOMY--Continued 3.2 Land Ownership
}

\section{Federal Government Owns Most of Land Surface}

\author{
The U.S. Bureau of Land Management and the U.S. Forest Service administer \\ nearly all the federally owned land.
}

The proportions of governmental and private landsurface ownership differ from county to county within Area 52, but the predominance of government surface ownership can be seen in figure 3.2-1. Only the principal ownership patterns are shown in figure 3.2-1; small inholdings, although they may be important cumulatively, are not shown. Specifically, each State owns sections 16 and 36 of every township (referred to as "school" sections), except where trades, purchases, or sales have been made (fig. 3.2-2).

The land-ownership pattern can be understood more clearly through the history of the area. The Federal Government retained ownership of all unclaimed lands, with the exception of the school sections, when Wyoming, Colorado, Idaho, and Utah were admitted to the Union. Sections 16 and 36 of every township were granted to the States upon admission to the Union. Revenues from these lands were to be used for education.

Jurisdiction of the federally owned land surface has been assigned largely through congressional legislation. Widespread overgrazing and misuse of Federal land in the western United States prompted passage of the Taylor Grazing Act of 1934 (fig. 3.2-3). The Act placed substantial areas of Federal land under the jurisdiction of an agency that is now the U.S. Bureau of Land Management in order to promote sound land-use practices. The U.S. Bureau of Reclamation later assumed jurisdiction from the U.S. Bureau of Land Management over lands near the Green and Big Sandy Rivers to facilitate irrigation projects. The Bridger, Wasatch, and Ashley National Forests were delineated and placed under U.S. Forest Service jurisdiction by Presidential proclamation. A part of the Bridger National Forest was given wilderness status by Congress in 1964. The Flaming Gorge National Recreation Area was partitioned from the Ashley National Forest in 1970.

The pattern of private land ownership shown in figure 3.2-1 developed in two ways. Lands along river valleys were homesteaded or bought during settlement of the area because of the availability of water for irrigation. The checkerboard pattern of private ownership transecting the area resulted from the Federal grant to the Union Pacific Railroad of the odd-numbered sections of land in a band 20 miles wide along each side of the railroad right-of-way. The grant was an incentive to build a transcontinental railway to benefit the settlement of the West. Some of the land was sold by the railroad for revenue. More detailed descriptions of land-ownership patterns are available for Wyoming (Calef, 1960) and for the Rocky Mountain region (Foss, 1960). 

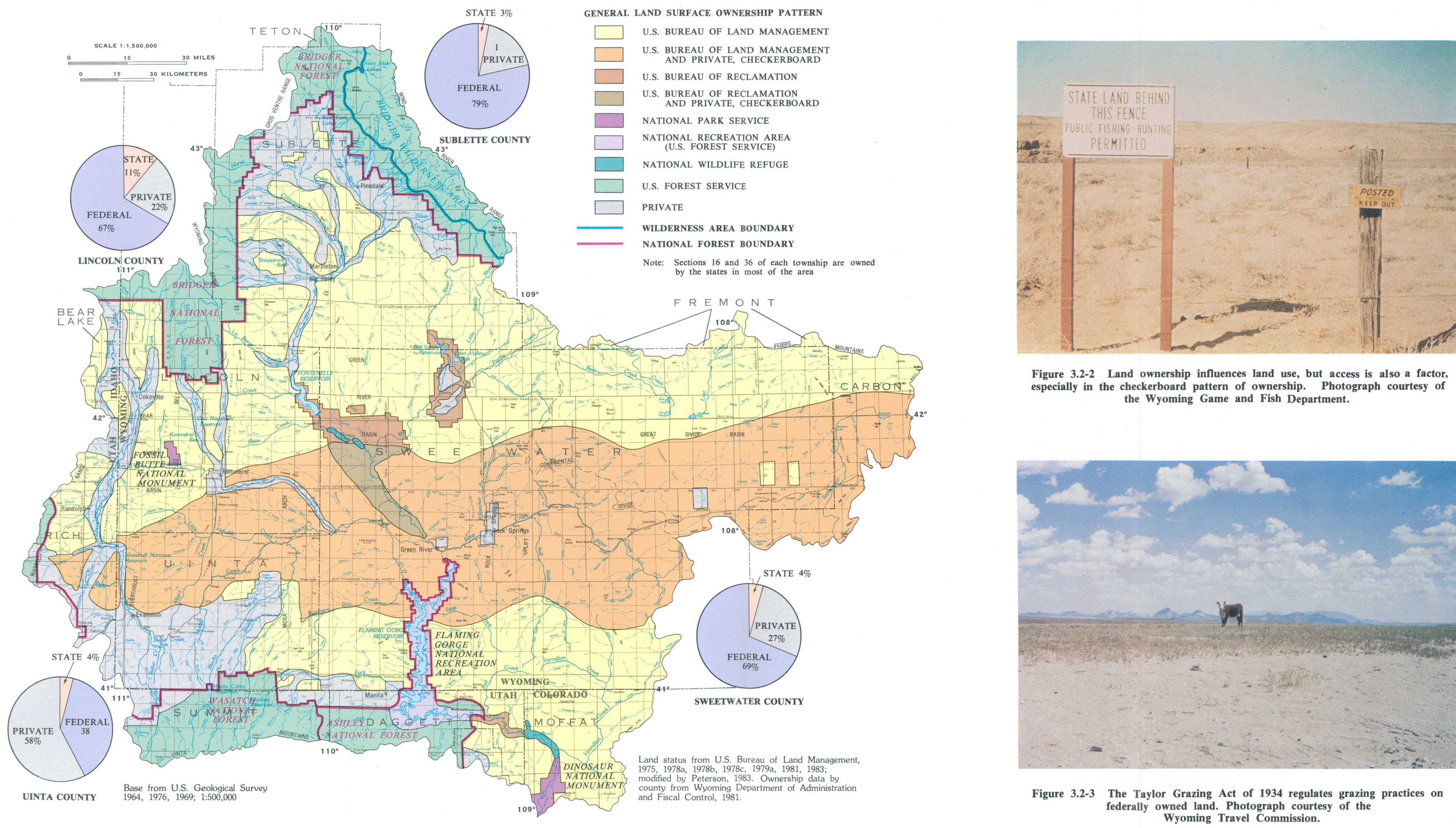
Figure 3.2-2 Land ownership influences land use, but access is also a factor,
especially in the checkerboard pattern of ownership. Photograph courtesy of We Wyoming Game and Fish Department.

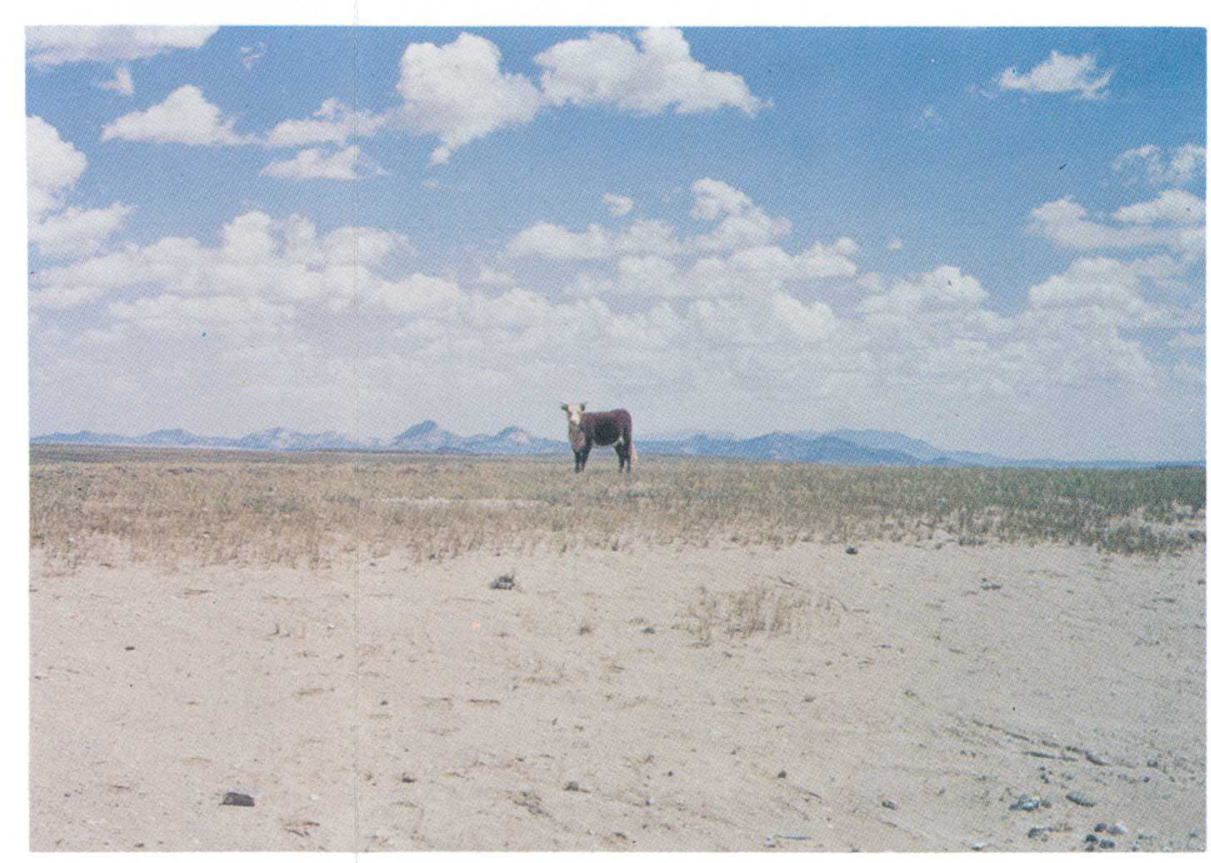

Figure 3.2-3 The Taylor Grazing Act of 1934 regulates grazing practices on federally owned land. Photograph courtesy of the
Wyoming Travel Commission. 


\subsection{RESOURCES AND ECONOMY--Continued 3.3 Coal}

\section{Billions of Tons of Low-Sulfur Coal Available}

\section{Two major coal regions contain more than 3 billion tons of strippable coal, mainly subbituminous with moderate heat value and low sulfur.}

The Green River and Hams Fork coal regions are partly in Area 52. The Green River coal region, which covers about 15,400 square miles in the Green River and Great Divide Basins, is Wyoming's largest coal-bearing area. Most of the strippable reserve base in these two coal regions is subbituminous although some strippable bituminous coal is found in Cretaceous rocks around the Rock Springs uplift (Glass, 1982, p. 672).

Because younger rocks conceal most of the coal bearing rocks in the Green River region, very little is known about the total coal reserves. The areal distribution of coal in Area 52 and areas of thick or abundant coal are shown on the map in figure 3.3-1. Estimated strippable coal reserves in the Green River coal region are 1,923,300,000 tons (Glass, 1982, p. 684).

Coal beds in the Green River coal region are in the Mesaverde Group and Lance Formation of Late Cretaceous Age, the Fort Union Formation of Paleocene age, and the Wasatch Formation of Eocene age. Beds in the Mesaverde Group are as much as 14 feet thick; those in the Lance generally are 5 to 10 feet thick. Fort Union coal beds are as much as 30 feet thick. Lenticular coal beds in the Wasatch Formation in the Great Divide Basin are as much as $\mathbf{4 0}$ feet thick.

The Hams Fork coal region is within the Overthrust belt. Glass (1982, table 9) estimated the original reserves of strippable coal of the Hams Fork coal region to be $1,064,800,000$ tons. The coal is in the Cretaceous Bear River, Frontier, and Adaville Formations, and the Cretaceous and Tertiary Evanston Formation. The Adaville is partly equivalent to the Mesaverde Group in the Green River region, and the Evanston is partly equivalent to the Cretaceous Lance and Tertiary Fort Union Formations. The Bear River and Evanston coal beds were formerly mined by underground methods, but little is known of the potential reserves or bed thicknesses. The structure in the Overthrust belt is very complex, so the continuity of beds is problematic. The Adaville is the principal coal-bearing formation in the Hams Fork coal region. The lower 1,200 feet of the formation contains as many as 32 coal beds, the thickest of which is 118 feet thick (Fagnant, 1962, as cited in Glass, 1982, p. 679). (See figure 3.3-2.)

The Frontier Formation contains as many as 10 minable beds. The thickest of these is as much as 20 feet thick, but most are less than 6 feet thick.

The economic value of coal deposits depends on quality considerations as well as thickness and availability. The most important quality considerations include the following:
Heat value--Important as an indicator of the potential energy available from burning of the coal. It generally is reported in Btu's (British thermal units) on an as-received basis. The larger the value the greater the heat output. Coal from Area 52 is somewhat lower in heat value than eastern coal.

Ash--An undesirable residue; generally is reported as a percentage by weight. It is about the same in coal from Area 52 as in that from other regions.

Sulfur--Produces an acid-forming gas, sulfur dioxide, when burned. It is reported as a percentage by weight. Coal from Area 52 is low in sulfur compared to most of that from other regions.

Moisture--Can cause slaking (disintegration) and spontaneous combustion in stored coal. It is reported as a percentage by weight. Area 52 coal is comparatively wet, requiring special care in storing and shipping.

These quality factors for coal from the Green River coal region, the Hams Fork coal region, the Appalachian region, the Northern Great Plains, and the Interior (provinces) are compared in table 3.3-1 (Glass, 1982, and Swanson and others, 1976).

Coal presently mined from Area 52 is lower in heat value than that from Appalachian and Interior coal fields, but is substantially lower in sulfur content, as illustrated in table 3.3-1. This comparatively low sulfur content is advantageous from the standpoint of pollution control; sulfur dioxide from burning coal is considered a noxious air pollutant. The coal's relatively low heat values also are offset by the relatively thick beds and the large reserves.

Most of the mined coal is used by coal-fired powerplants; other major uses are the trona, phosphate, and cement industries. Formerly, such towns as Rock Springs, Rawlins, Kemmerer, and Evanston were developed around underground mines supplying coal for railroad locomotives; most mining presently (1983) is done in large open-pit mines.

Coal production has greatly increased since 1970 , as shown on the graph in figure 3.3-3. Seven open-pit mines are active (fig. 3.3-1); the last of many underground mines closed in 1982. Mining began when the railroad was built in the 1860's but languished when diesel locomotives supplanted coal-fired steam locomotives in the 1950's. Cumulative production exceeds 360 million tons. Several new mines have been proposed in anticipation of future demand. 
Table 3.3-1 Characteristics of coal from Area 52

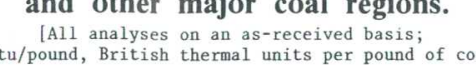

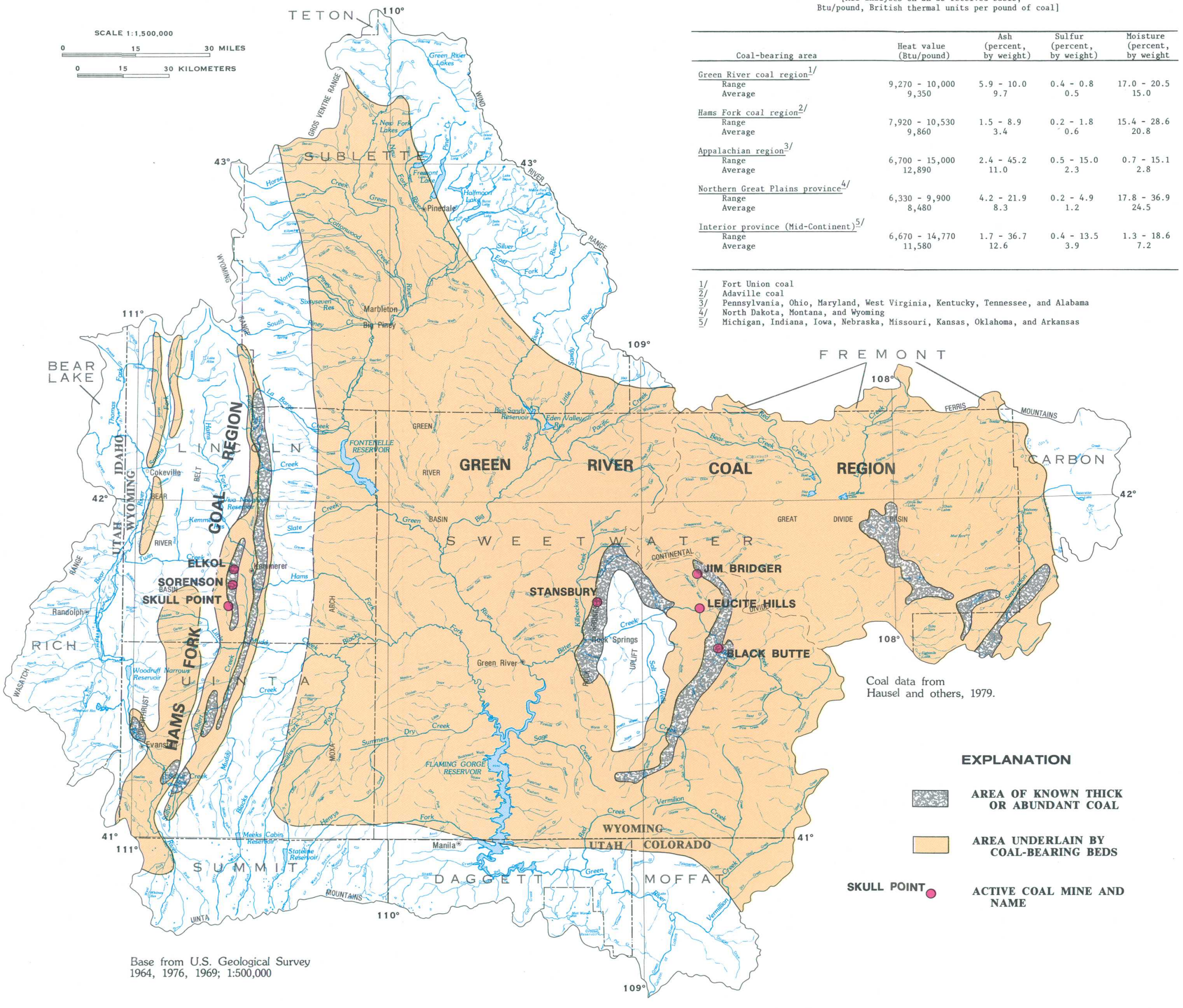

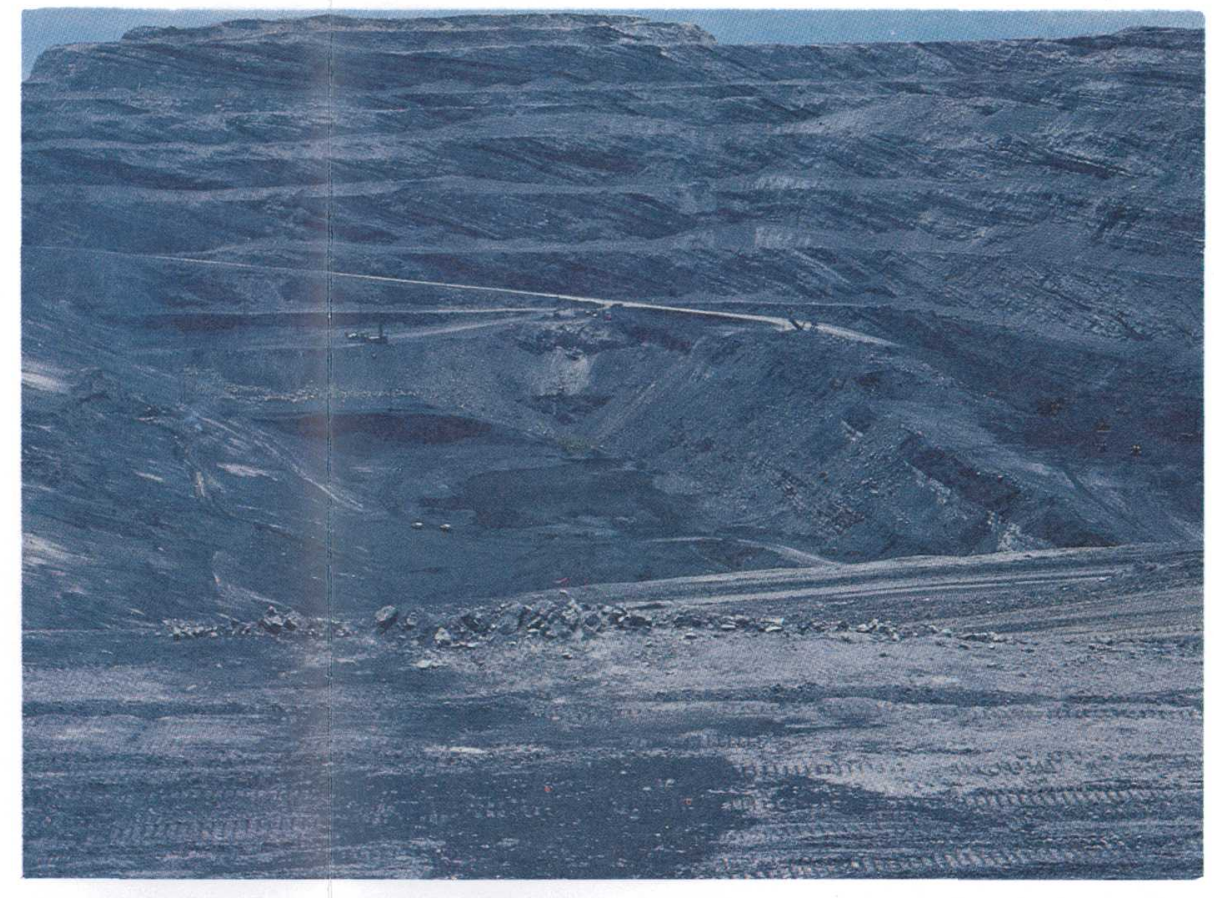

Figure 3.3-2 Open-pit coal mining at Elkol mine. Scale is shown by the vehicles in the mine bottom.

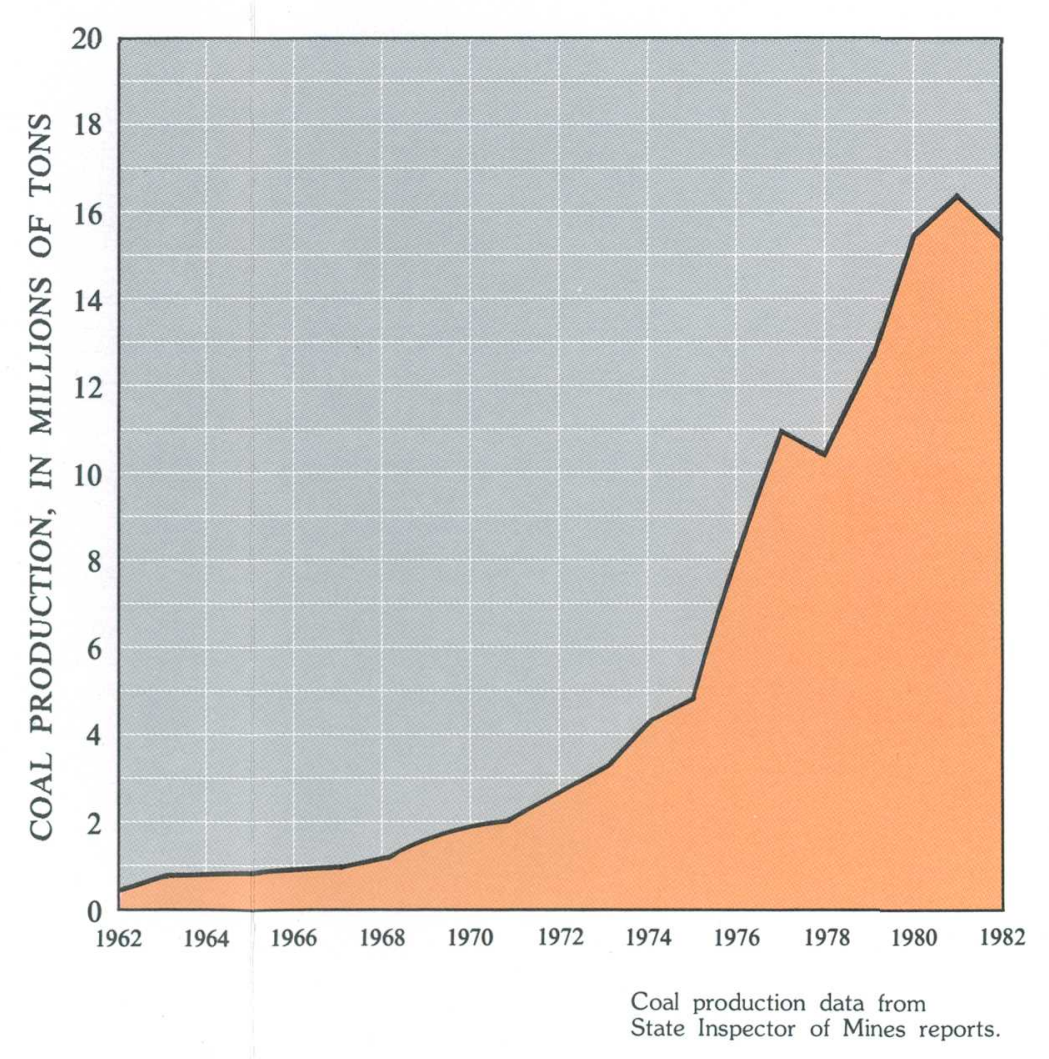

Figure 3.3-3 Coal production in Area 52 from 1962 through 1982 . 


\title{
3.0 RESOURCES AND ECONOMY--Continued 3.4 Other Minerals
}

\section{A Diversity of Minerals Produced in the Area}

\author{
Oil and natural gas, oil shale, trona, phosphate, and uranium are presently or \\ potentially important in the area; sodium sulfate, gravel, sand, pumice, scoria, \\ fossil fish, and limestone also are present.
}

\begin{abstract}
A wide variety of mineral resources other than coal are present in Area 52. Some are now developed; others await changed economic conditions to justify development. Distribution of these minerals is shown in figure 3.4-1.
\end{abstract}

More than 100 oilfields or gasfields have been discovered within the area. Many of these are marginal producers or have been abandoned, but some are giant fields. Most of the older fields are along the trend of the Rock Springs uplift or the Moxa arch, a north-trending anticline near the west edge of the Green River Basin. Improved exploration techniques employed in the mid-1970's led to major discoveries in the Overthrust belt (fig. 3.4-2). These discoveries combined with relatively high prices led to intense exploration, which was curtailed somewhat when prices fell in 1982.

Some of the large gasfields in the Overthrust belt produce impure gas that requires extensive treatment to make it suitable for pipeline sale. Much of the gas is "sour," that is, it contains poisonous hydrogen-sulfide gas that must be removed. The treatment to remove this noxious gas yields elemental sulfur in commercial quantities. Nitrogen, carbon dioxide, and helium also are recoverable in substantial amounts.

The extensive sediments laid down in ancient Lake Gosiute include substantial thicknesses of oil shale. The total shale-oil resource is estimated to be about 244 billion barrels (Culbertson and others, 1980, p. 1). No commercial development has yet (1983) taken place; the U.S. Department of Energy conducted extensive experiments in the 1960's and 1970's on various techniques to retort (distill) the oil shale in place underground. Although the resource is abundant, favorable economic conditions and improved technology may be needed to promote commercial development.

During the cycles of expansion and contraction of Lake Gosiute, the lake was, at times, nearly dried up. This drying concentrated the salts in the water until they precipitated as bedded deposits. A remarkable suite of saline minerals was laid down in as many as 42 beds, some more than $\mathbf{1 0}$ feet thick. Of these saline minerals, trona, a hydrous carbonate of sodium, is the most abundant and commercially important. It is mined at several places and refined into soda ash, an industrial chemical used in the manufacture of glass (fig. 3.4-3). Reserves as great as 100 billion tons have been estimated (Hausel and others, 1979). Area 52 contains the largest deposits of trona in the world.

Phosphate rock is abundant in the Phosphoria Formation that crops out in strips in the Overthrust belt. One mine operates near the Wyoming-Utah State line, and several others were formerly operated. Low-grade uraniferous phosphate also abounds in the sediments of ancient Lake Gosiute.

Numerous discoveries of uranium have been made in the eastern part of Area 52. Development is very sensitive to economic conditions; it was rapid in the 1970's when prices were high but was sharply curtailed in the early 1980's when prices fell. Although many mines were under development in the late 1970's and underground leaching experiments were begun, only one mine was operated in 1982 (Wyoming State Inspector of Mines, 1982).

In addition to these major mineral resources, minor occurrences of several mineral or rock resources are found in Area 52. Sodium sulfate and carbonate beds underlie several ephemeral lakes in the Great Divide Basin and have been mined at one site. Gravel and sand generally are abundant throughout the area. Pumice and scoria from small volcanic deposits are under development. The abundant fish fossils in Lake Gosiute sediments (Green River Formation) are part of the basis for establishment of Fossil Butte National Monument near Kemmerer, Wyo. Fossils also are the stock in trade of several entrepreneurs who mine, process, and sell them as tourist attractions, jewelry, collector's items, and museum specimens. Jade is found in parts of the Great Divide Basin. Limestone can be obtained in large quantities from beds in most of the mountainous parts of the area; impure limestone is abundant almost anywhere. 

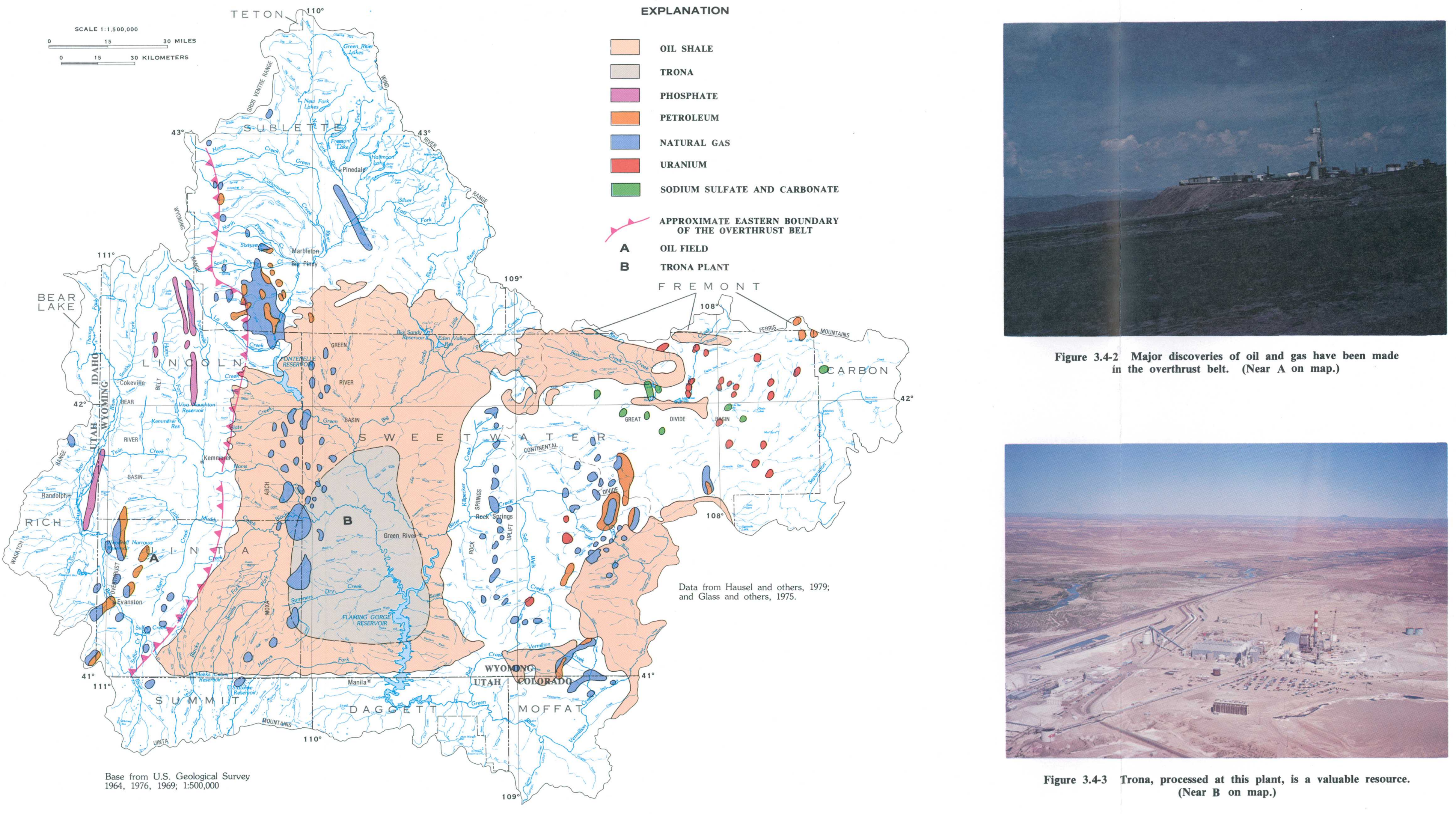

Figure 3.4-2 Major discoveries of oil and gas have been made
in the overthrust belt. (Near A on map.)

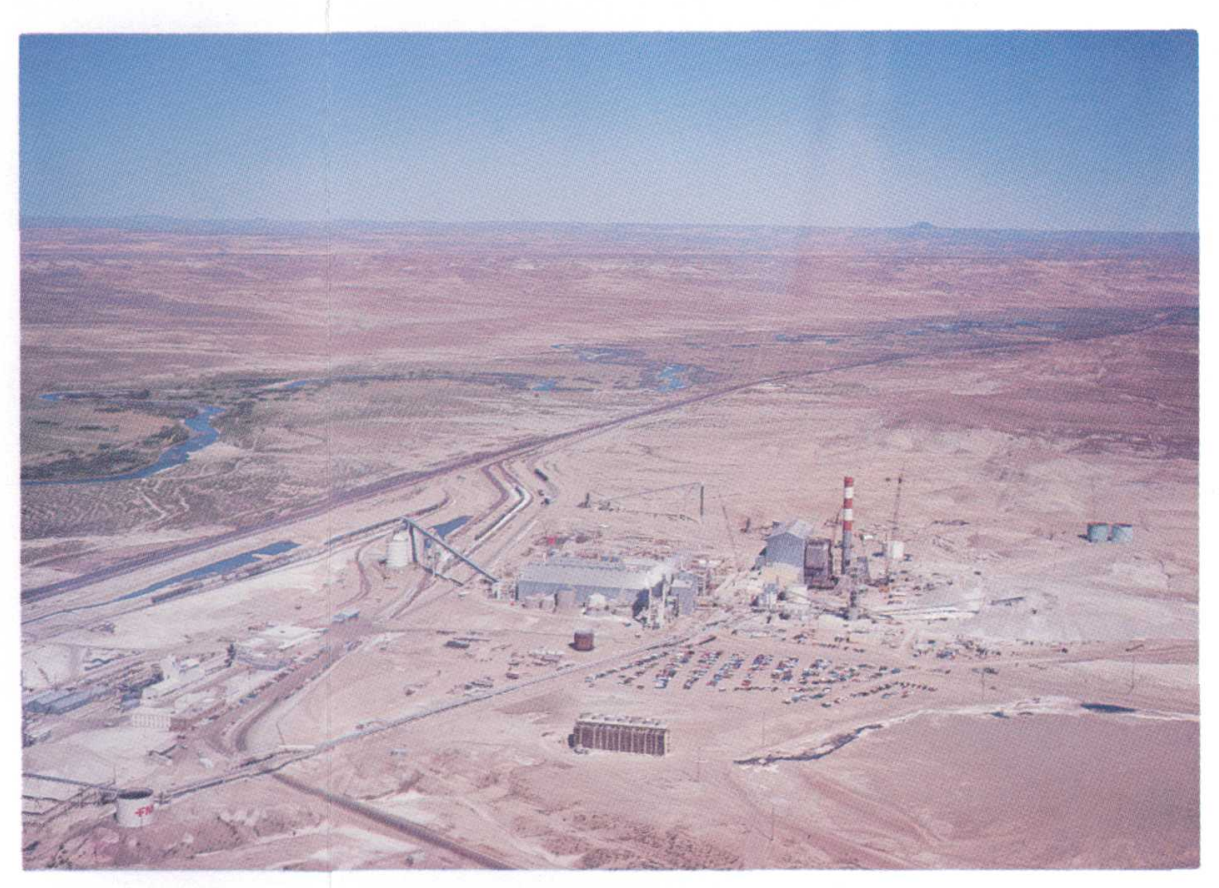

Figure 3.4-3 Trona, processed at this plant, is a valuable resource. 


\subsection{RESOURCES AND ECONOMY--Continued 3.5 Mineral Ownership}

\section{Federal Government Owns Most Mineral Rights}

The Federal mineral rights are managed by the U.S. Bureau of Land Management.

The proportion of mineral rights owned by the Federal Government is large compared to the proportion of privately owned mineral rights (fig. 3.5-1). The U.S. Bureau of Land Management evaluates tracts and conducts leasing programs to make the coal, oil, gas, and other minerals available to the public. Mineral companies often utilize a combination of mineral-right leases from the Federal and State Governments and privately owned mineral rights (fig. 3.5-2). A combination of mineral rights may enable a company to extend its mining operation or to mine an area where one owner's share of the mineral rights does not contain sufficient reserves to be economically mineable.

The mineral ownership pattern in the area often is identical to the land surface ownership pattern. The Federal Government retained ownership of the mineral rights and the land surface in most of the area when Wyoming, Colorado, Idaho, and Utah were admitted to the Union.
Ownership of the mineral rights and land surface of Sections 16 and 36 of each township was granted to those States by the Federal Government, upon admission to the Union. State ownership of the mineral rights and land surface to these sections still prevails in most of the area, except where trades, purchases, or sales have been made.

The early homesteaders were granted the mineral rights to their land, but the Federal Government retained the mineral rights to private lands claimed after the Homestead Act of 1916. The checkerboard pattern of private and Federal mineral ownership that transects Area 52 resulted from the Federal grant to the Union Pacific Railroad of the odd-numbered sections in a band 20 miles wide along each side of the railroad right-of-way (fig. 3.5-3). The grant was an incentive to build a transcontinental railway. 

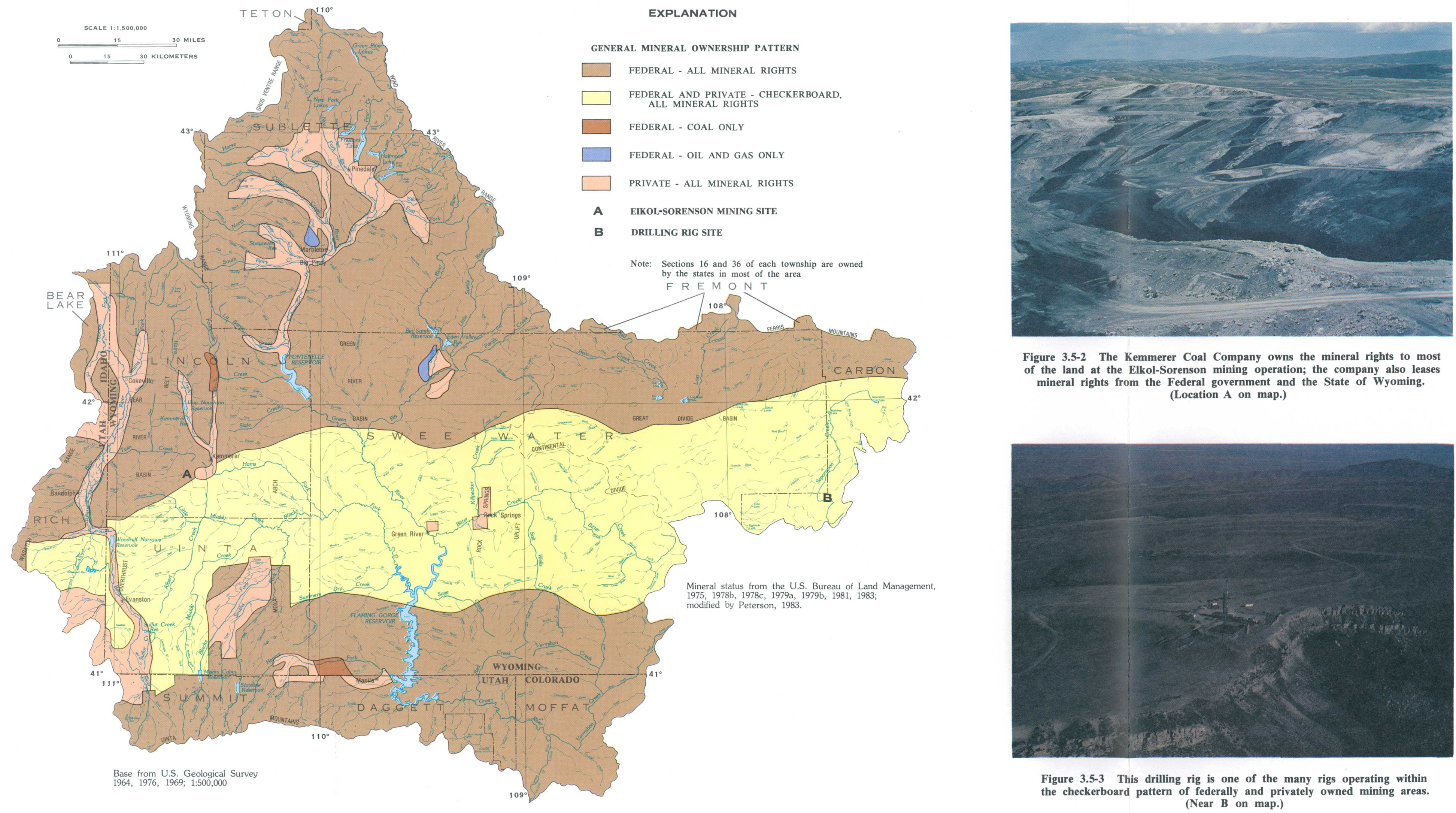
Figure 3.5-2 The Kemmerer Coal Company owns the mineral rights to most
of the land at the Elkol-Sorenson mining operation; the company also leases mineral rights from the Federal government and the State of Wyoming. (Location A on map.)

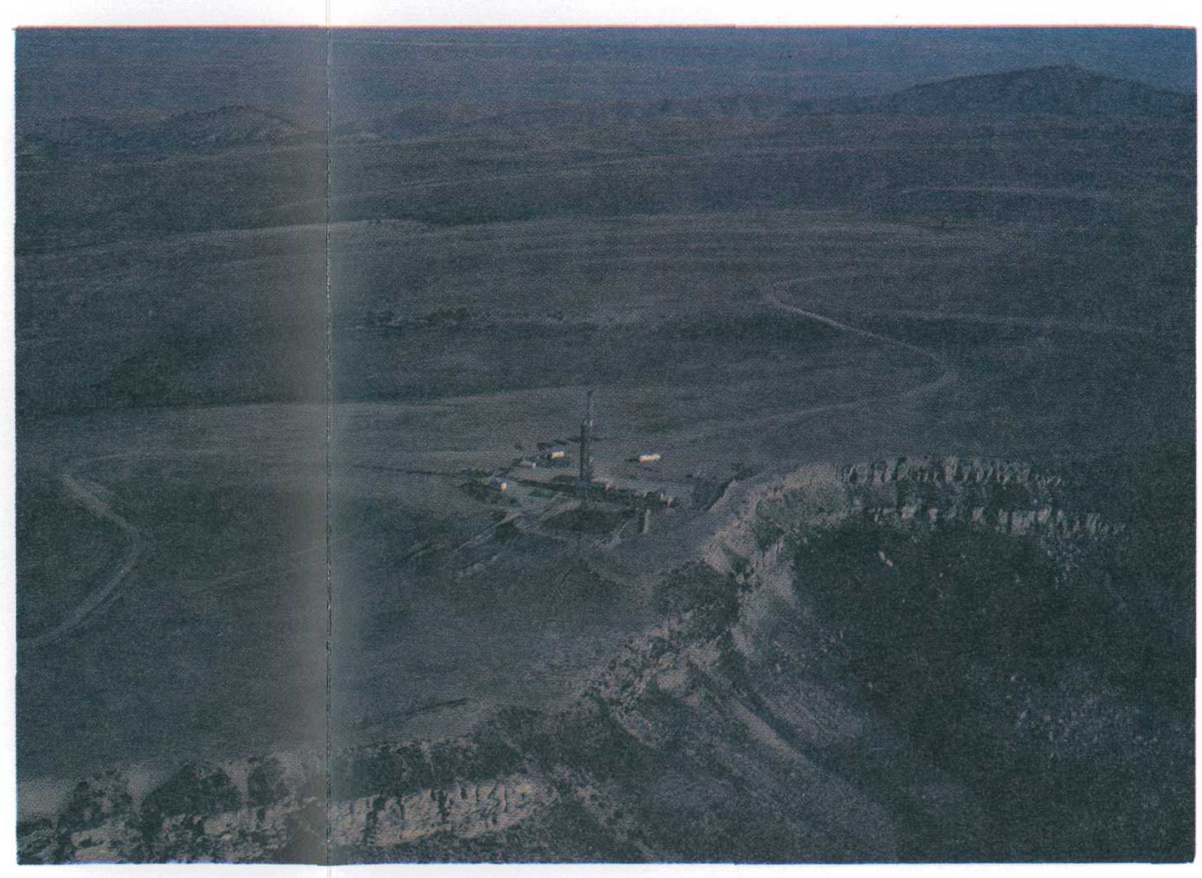

Figure 3.5-3 This drilling rig is one of the many rigs operating within
the checkerboard pattern of federally and privately owned mining areas. (Near B on map.) 


\title{
3.0 RESOURCES AND ECONOMY--Continued 3.6 Water Use
}

\section{Irrigation Consumes the Largest Amount of Water}

\author{
Recreation, fish and wildlife habitat, and hydroelectric production are \\ important uses that are largely nonconsumptive.
}

Total water consumption in the area averages about 513,000 acre-feet annually. (One acre-foot is the volume that would cover 1 acre to a depth of 1 foot.) Irrigation is the largest consumptive use, consuming an average of 421,000 acre-feet annually. A mosaic of infrared imagery taken from a Landsat satellite is shown in figure 3.6-1. The imagery uses false colors that highlight certain features such as vegetation and soils. The forested mountain areas are dark red. Irrigated areas are bright red or pink. Rocky, unforested mountainous areas and sand dunes are light grey.

Most of the irrigated lands are located near the larger perennial streams (fig. 3.6-2). Nearly all of the water used for irrigation is diverted from streams. Industries that use significant amounts of water, such as the two coal-fired powerplants and the trona-mining operations, also use surface water. Hydroelectric power generation is an important use of water in the area (fig. 3.6-3). Two dams, Flaming Gorge and Fontenelle, have generating plants.

Ground water is widely used for livestock watering and for rural domestic supplies; however, the amount of ground water consumed is small in comparison to surfacewater consumption. Industrial uses of ground water include oil-well drilling, secondary recovery of oil, and highway construction.

Water-based recreation is largely a nonconsumptive use. Boating, fishing, hiking, camping, and hunting are popular activities in the Green and Bear River Basins.

The Green and Bear Rivers are interstate streams, and their waters are apportioned among the states involved by interstate compact agreements (Rechard and Ragsdale, 1971 , p. 12-26, 37-44). The Green River is part of the Colorado River Basin, and its water is apportioned among seven states by the Colorado River Compact of 1922 and the Upper Colorado River Basin Compact of 1948. The Bear River Compact of 1955 provides for administration of water in the Bear River among the States of Idaho, Utah, and Wyoming. The compact agreements specify the amounts of water that may be used in each State; they are therefore important to the development and use of water.

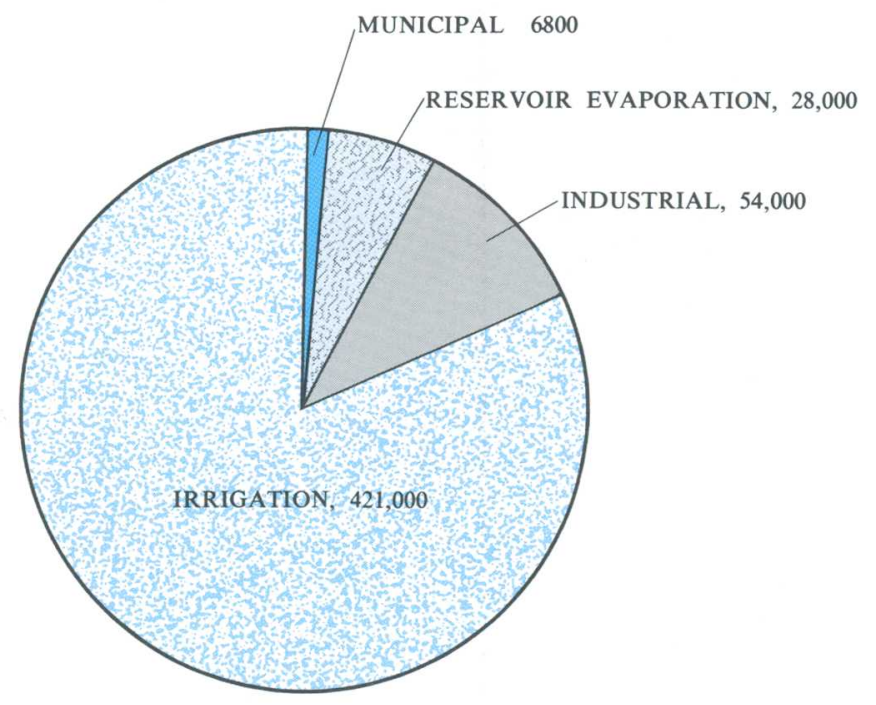

WATER CONSUMPTION, IN ACRE-FEET 

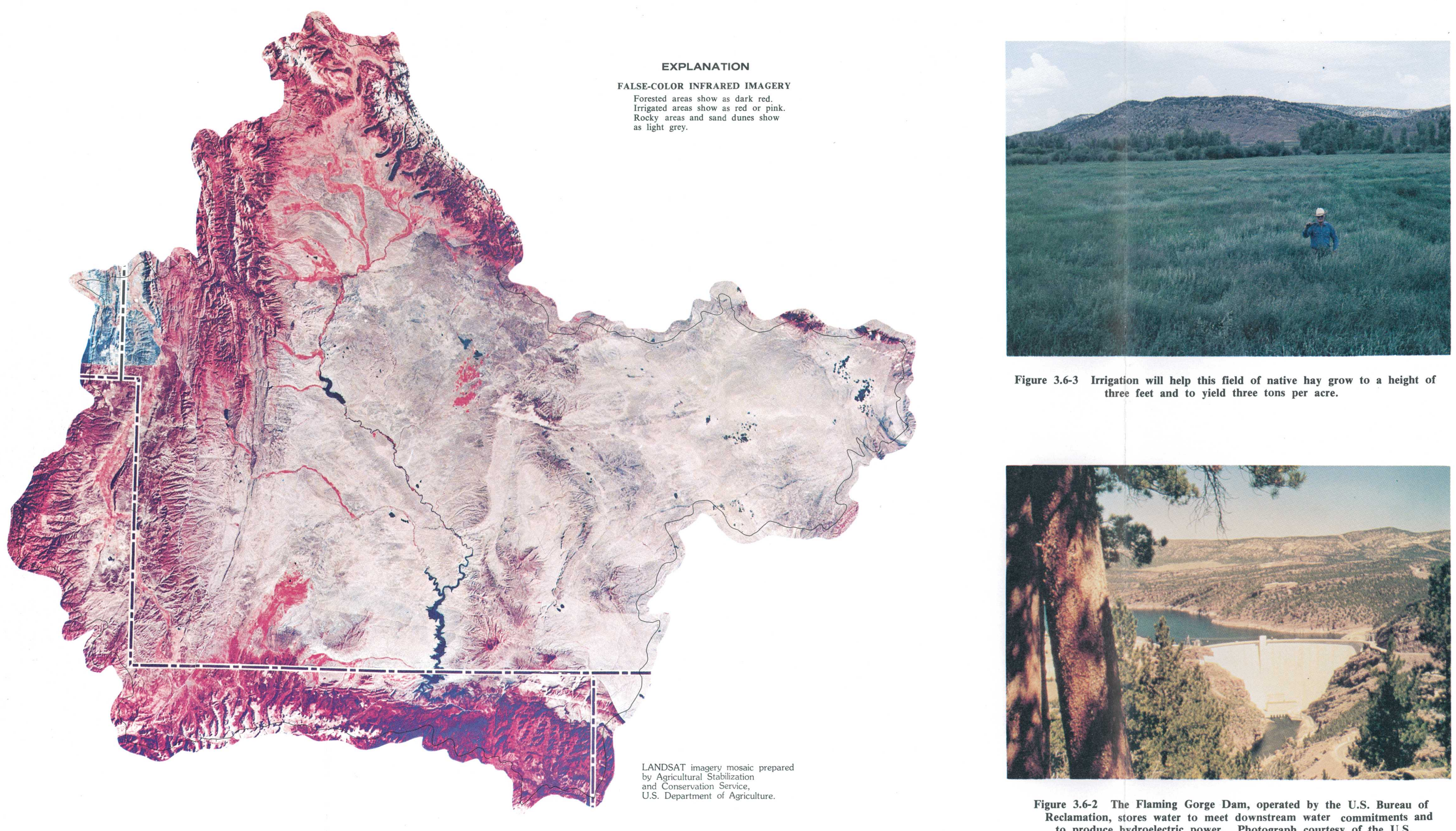
Figure 3.6-3 Irrigation will help this field of native hay grow to a height of
three feet and to yield three tons per acre.

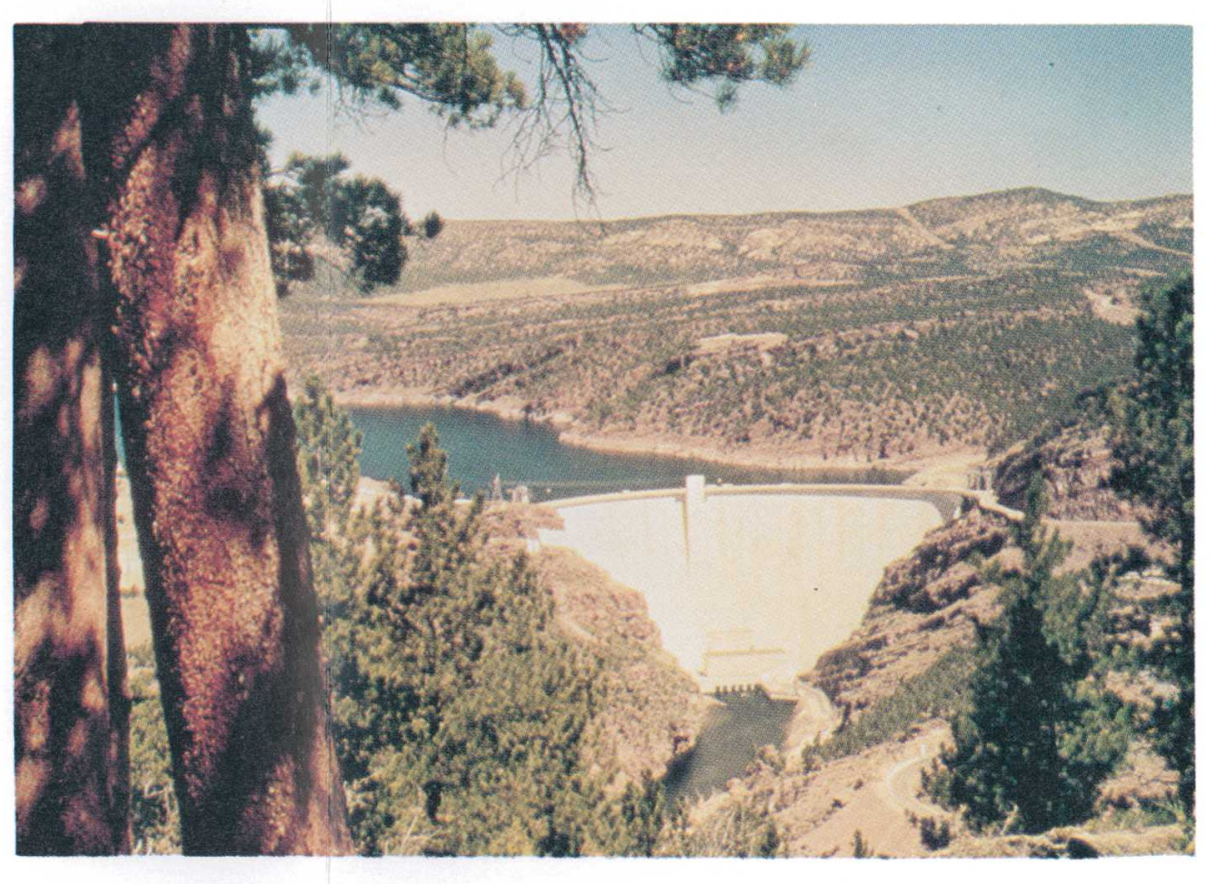

Figure 3.6-2 The Flaming Gorge Dam, operated by the U.S. Bureau of to produce hydroelectric power. Photograph courtesy of the U.S.
Bureau of Reclamation. 


\title{
4.0 SURFACE-WATER NETWORK \\ 4.1 Surface-Water Stations
}

\section{Surface-Water Data are Collected on a Systematic Basis at Gaging and Sampling Stations}

\author{
Streamflow-gaging and sampling stations are operated for a variety of purposes, \\ but the main use of data in the past has been for planning and management of \\ irrigation supplies.
}

Surface-water data have been collected on a systematic basis at gaging and sampling stations (fig. 4.1-1). At these locations, equipment has been installed and data have been collected continuously or at given intervals for a year or more. Each of these sites is considered to be a surface-water station. Specific information about the stations is given in Section 11.1 of this report. Site numbers, ranging from 1 to 220 , are used in this report to identify each station.

Continuous-record stations (fig. 4.1-2), which have a gage installation and water-level recorder, yield a comprehensive record of streamflow or reservoir contents. Stations of this type have been operated at 154 sites in the area. Most of these stations have been installed and operated for the planning and management of irrigation supplies.

For some purposes, such as for the design of bridges and culverts, only information about peak flows is necessary. A protected staff gage is installed at these locations, and it records the maximum stages of floods (fig. 4.1-3). The peak discharge is determined for each maximum recorded stage. These sites are often referred to as crest-stage stations. The amount of equipment and work needed for crest-stage stations are much less than that needed for continuous-record stations; hence, they are less expensive to operate. Peak-flow (or crest-stage) stations have been operated at 35 sites in the area.

Water samples have been collected at many of the stations in the area. Chemical-quality data are available for 115 sites, suspended-sediment data for 86 sites, and biological data for 55 sites.

The quality of water in streams changes with the seasons and the magnitude of the discharge. A single sample defines the kinds and concentrations of material in the water only at the time of sampling. Water samples are therefore generally collected monthly or daily to define water quality throughout the year.
Records of streamflow, reservoir contents, and water quality are published in annual reports of the U.S. Geological Survey. They also may be retrieved through computerized systems that are described in Section 10.0 of this report.

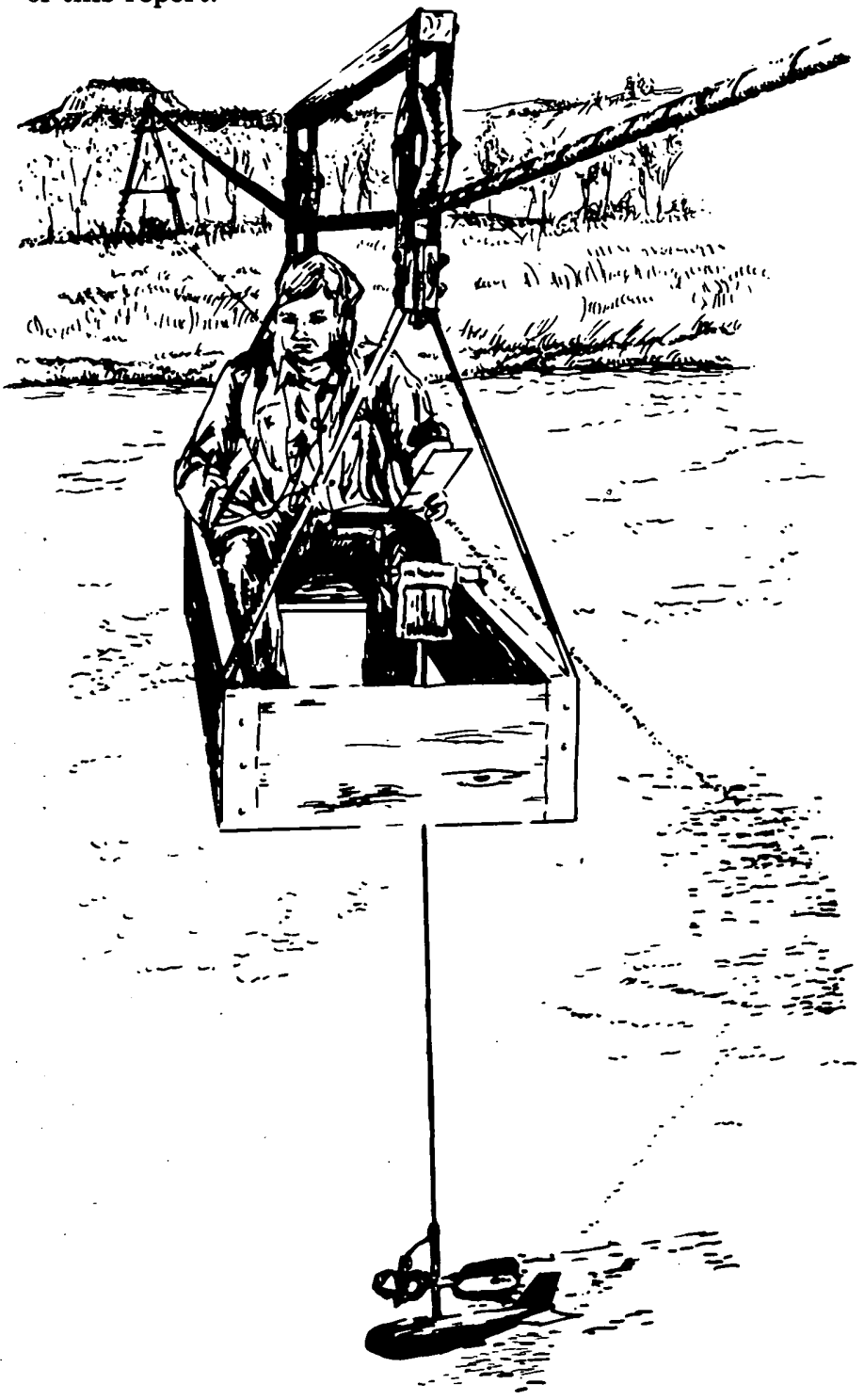




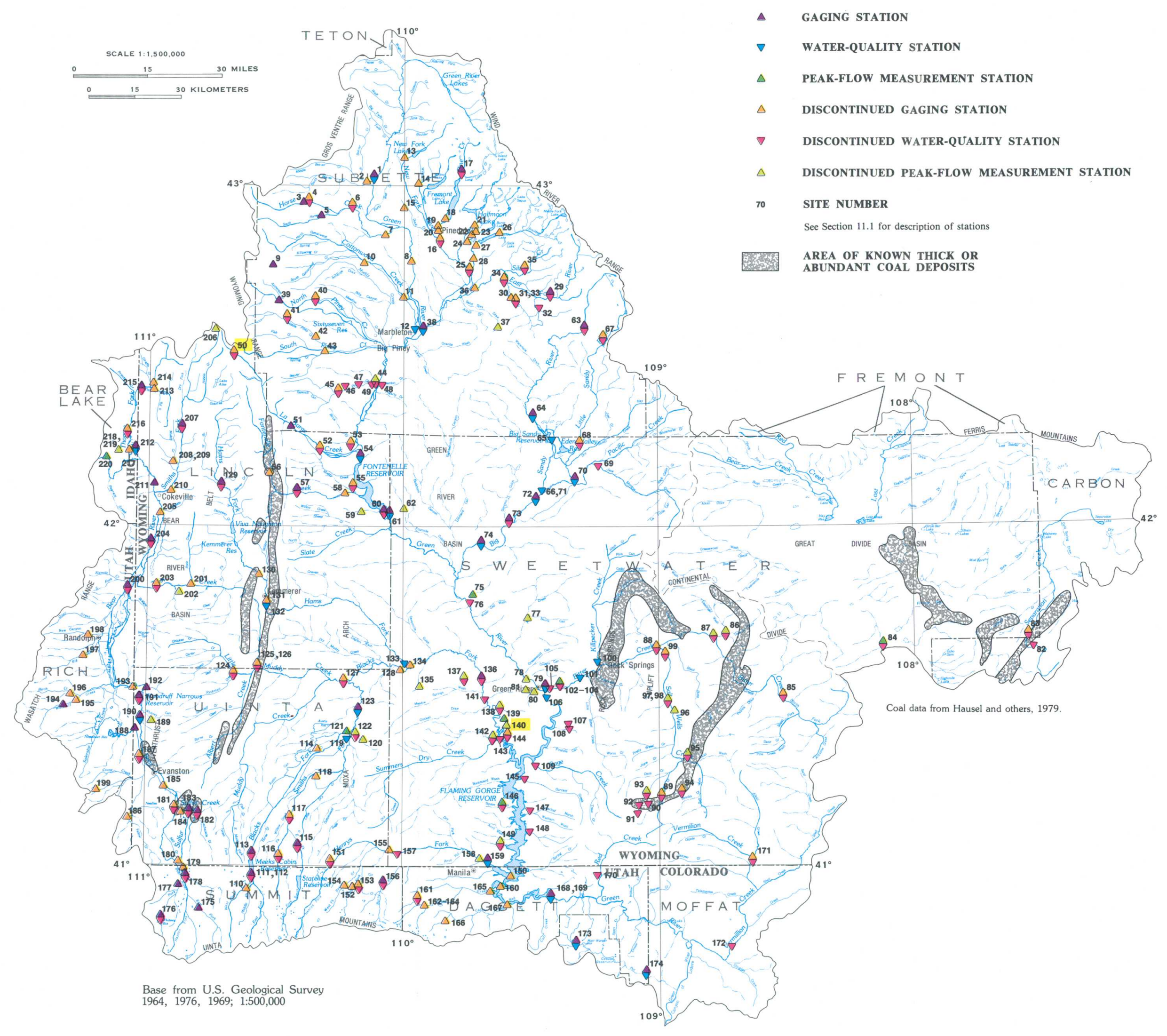

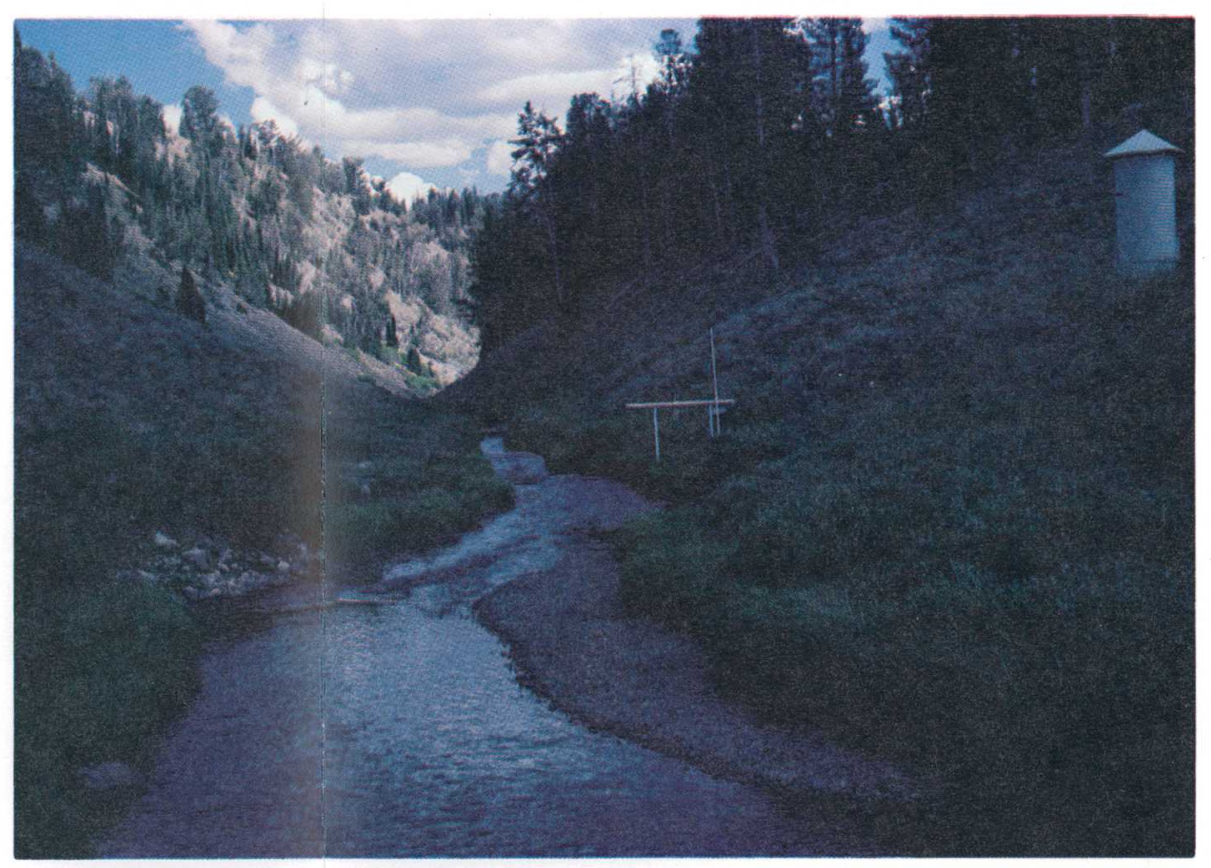

Figure 4.1-2 A continuous-record gage installation on La Barge Creek (site 50).

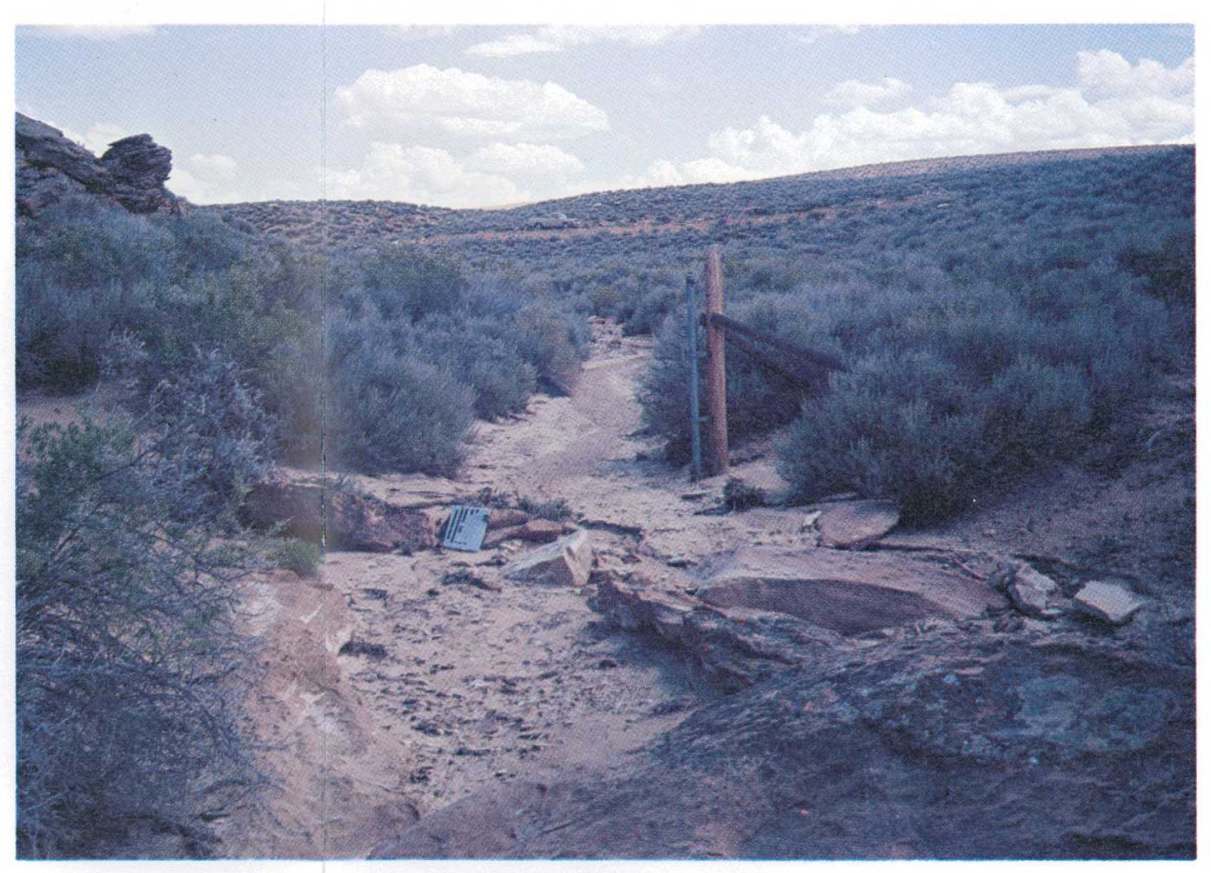

Figure 4.1-3 A peak-flow gage installation on Blacks Fork tributary No. 4 (site 140). 


\subsection{SURFACE-WATER NETWORK--Continued \\ 4.2 Miscellaneous Sites}

\section{Miscellaneous Measurements or Samples Required for Special Studies}

\section{Miscellaneous discharge measurements or water samples have been obtained at 268 sites on streams, lakes, and reservoirs in Area 52.}

Surface-water studies sometimes require information at locations where gaging or sampling stations are not operated. For example, to determine water loss or gain from seepage in a particular reach of stream may require measurements of discharge at several different locations along the reach. In a similar example, the water-quality assessment of a stream may require that samples of the flow be collected at several different locations as it moves downstream and receives inflows from tributaries. Locations where only one or a few measurements or samples are obtained are known as miscellaneous sites (fig. 4.2-1).

The miscellaneous sites used in this report have been assigned simplified site numbers ranging from 221 to 488 . Information about the sites is given in Section 11.2.

Many of the sites were established during 1976-78 as part of a comprehensive program to determine the waterquality characteristics of streams in the plains areas. Measurement and sampling were done during the spring months of snowmelt and rainfall runoff (fig. 4.2-2), and again during the fall months at sites where there was flow (fig. 4.2-3). The program was carried out by the U.S. Geological Survey with financial assistance from the U.S. Bureau of Land Management, which is in charge of administering a large amount of Federal land in the area.

Intensive hydrologic studies have been made by Lowham and others (1982) of Salt Wells Creek, and by Larson and Zimmerman (1981) of Separation Creek (fig. 4.3-1). These two streams mainly drain plains areas with potentially strippable coal deposits. The studies were made by the Survey in cooperation with the Bureau of Land Management as part of their Energy Mineral Rehabilitation Inventory and Analysis Program. Hydrologic processes unique to plains areas were identified by the studies; this knowledge can be applied as an aid to the planning of coal mining and reclamation throughout the plains of Area 52. 

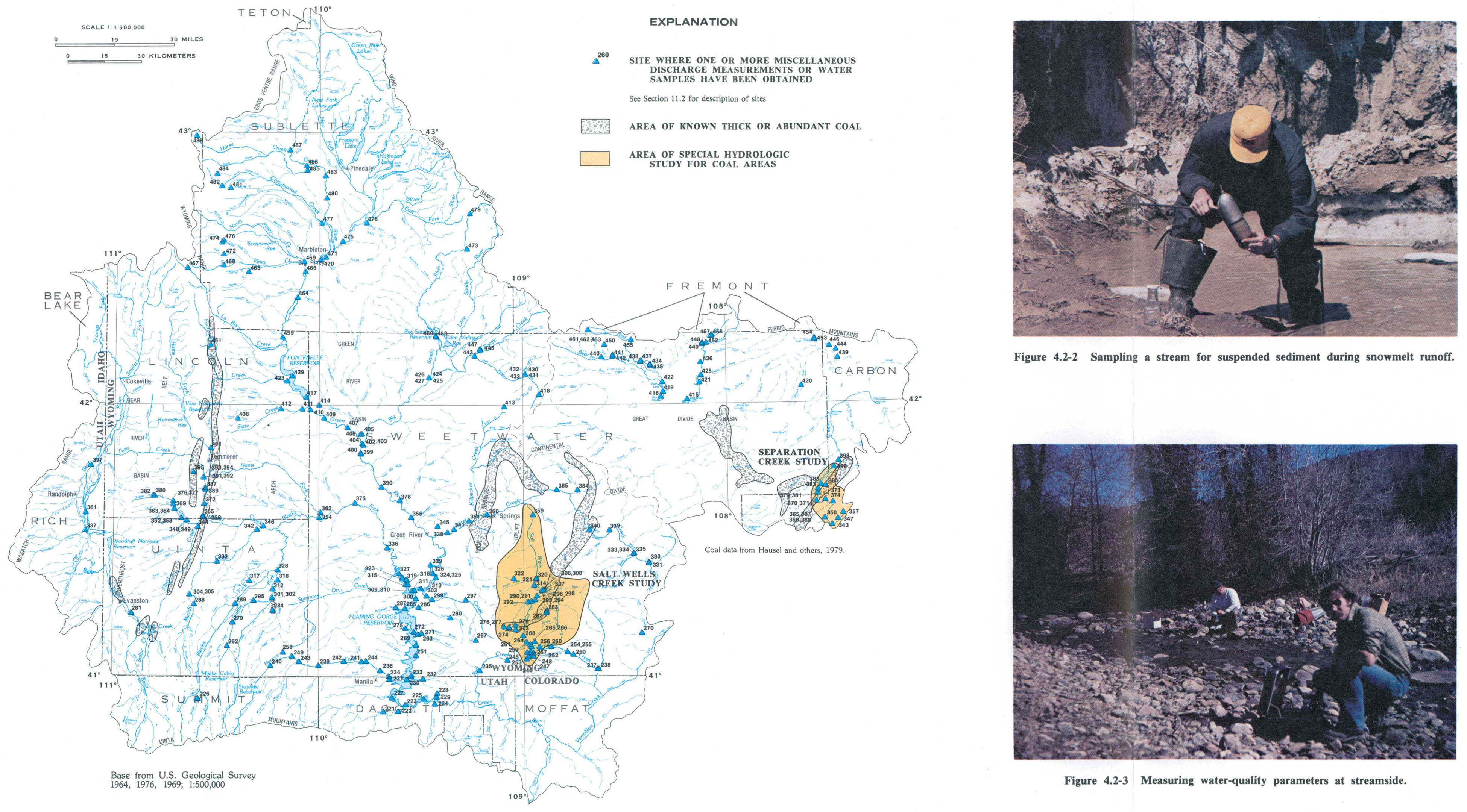

Figure 4.2-2 Sampling a stream for suspended sediment during snowmelt runoff 


\subsection{SURFACE-WATER QUANTITY 5.1 Cause and Occurrence}

\section{Snowmelt is the Source of Most Runoff}

\section{The major streams head in the mountainous areas where precipitation is greatest.}

A variety of stream types exist in the area due to differences in the climate and geology. Perennial streams, such as the Green River and its tributaries, originate in the mountainous areas where significant annual precipitation occurs and where geologic conditions induce ground-water discharge. Streams originating in the interior semiarid and arid plains areas generally are ephemeral, flowing mainly in direct response to rainstorms and snowmelt with little or no ground-water contribution.

The major part of annual runoff for streams draining mountainous areas occurs during spring and early summer as a result of snowmelt (fig. 5.1-1). Streamflow generally peaks during June, although this varies annually from site to site depending on local climatic conditions and on physical features of the individual basins. Late summer, fall, and winter flows are largely the result of ground-water inflows. Minimum streamflows occur during January through March. The total amount of runoff that occurs during any particular year is highly related to the amount of precipitation (fig. 5.1-2).

Intermittent and ephemeral streams that drain the plains areas flow only periodically and often have extended periods of no flow (fig. 5.1-3). These streams may receive some ground-water inflows in addition to direct surface runoff, however, the ground-water inflows are insufficient to sustain flow throughout the year. There are springs in some areas of the plains, and these springs commonly contribute small perennial inflows to streams. However, losses of water to evaporation, transpiration, seepage, and freezeup generally limit the extent of these flows only to short reaches downstream from the springs.

The classification of a stream as being perennial, intermittent, or ephemeral is somewhat arbitrary. It depends on which reach of the stream is being considered and the length of time the stream has been observed. The strict classification of a large plains stream is especially difficult, as such a stream may have perennial flows from springs in its headwater tributaries, yet downstream reaches may have flows only several times per year. Salt Wells Creek is such a stream. Several of its headwater tributaries have perennial flows, but these are lost within short distances due to seepage and evapotranspiration. Tributaries entering downstream reaches of the main channel are ephemeral. The downstream reach of the main channel has flow only several times per year. The major part of flow at the gaged site near the mouth occurs as a result of direct runoff from precipitation. However, runoff may continue for several days as a result of continued snowmelt or delayed inflows from upstream bank storage. The stream as a whole is, therefore, considered to be intermittent. 


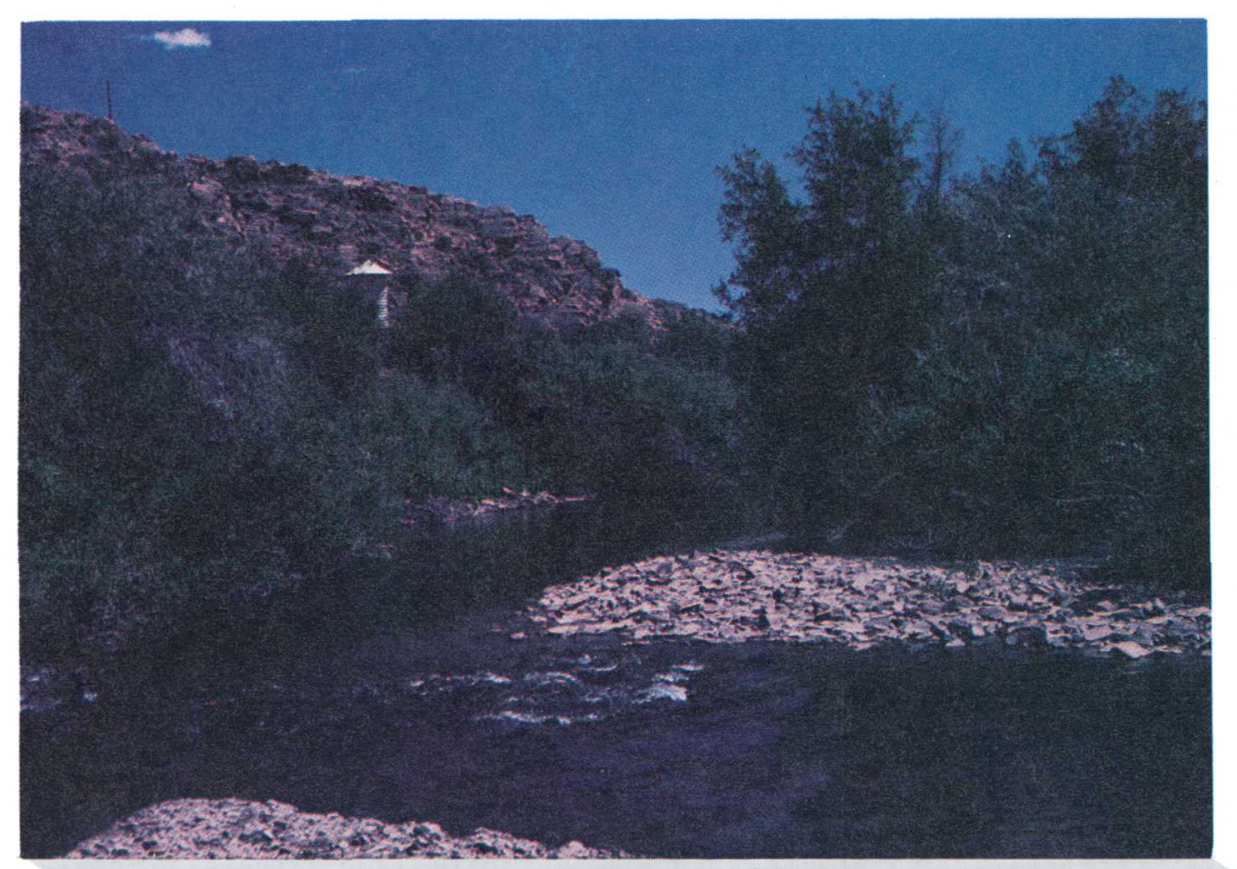

The drainage of Fontenelle Creek upstream from this reach at site 57 is at

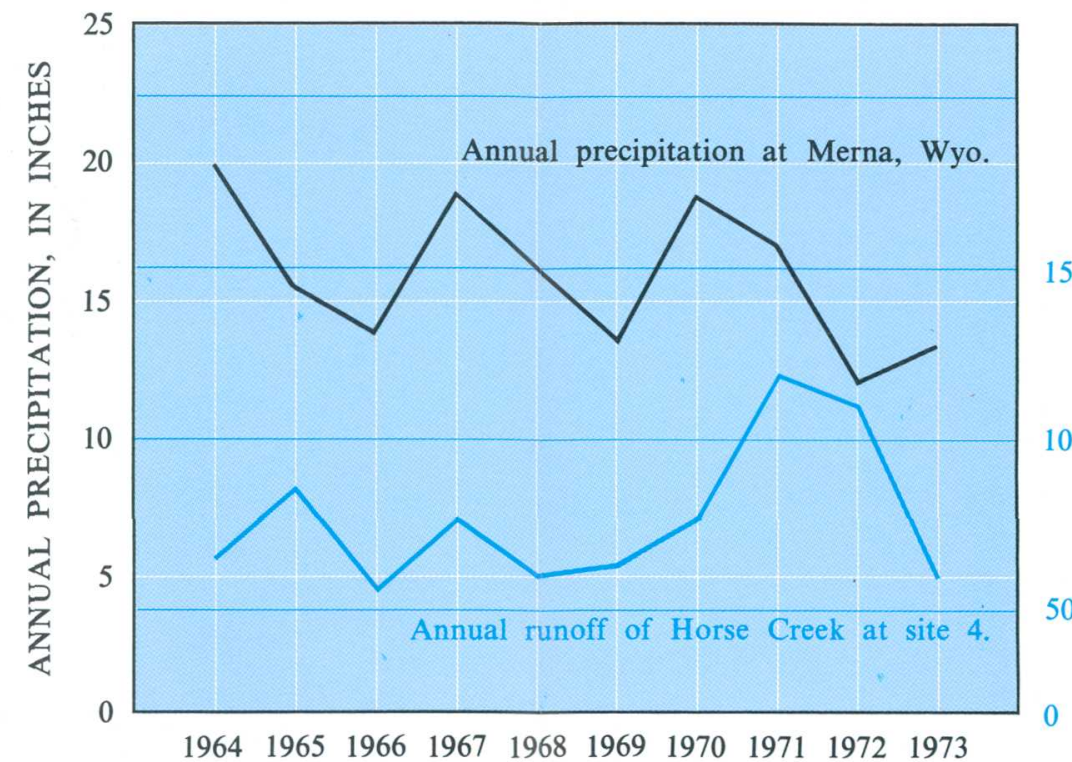

YEAR Figure 5.1-2 Runoff is dependent upon precipitation, although
there is often a lag due to the accumulation of snow during

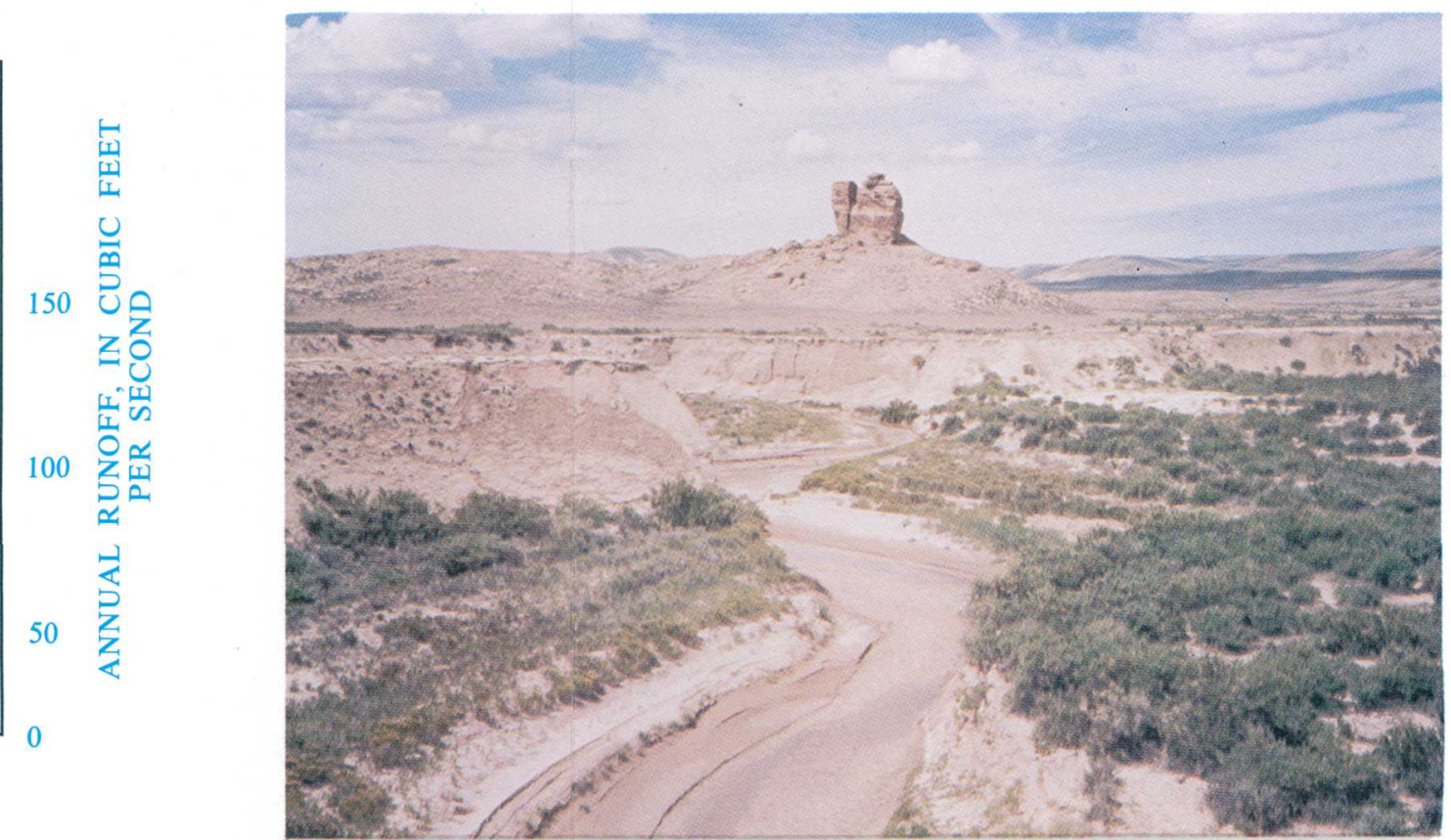

The interior plains receive from 7 to 10 inches precipitation per year; about half of this occurs as snow. Most of the streams originating
in the plains are ephemeral or intermittent.
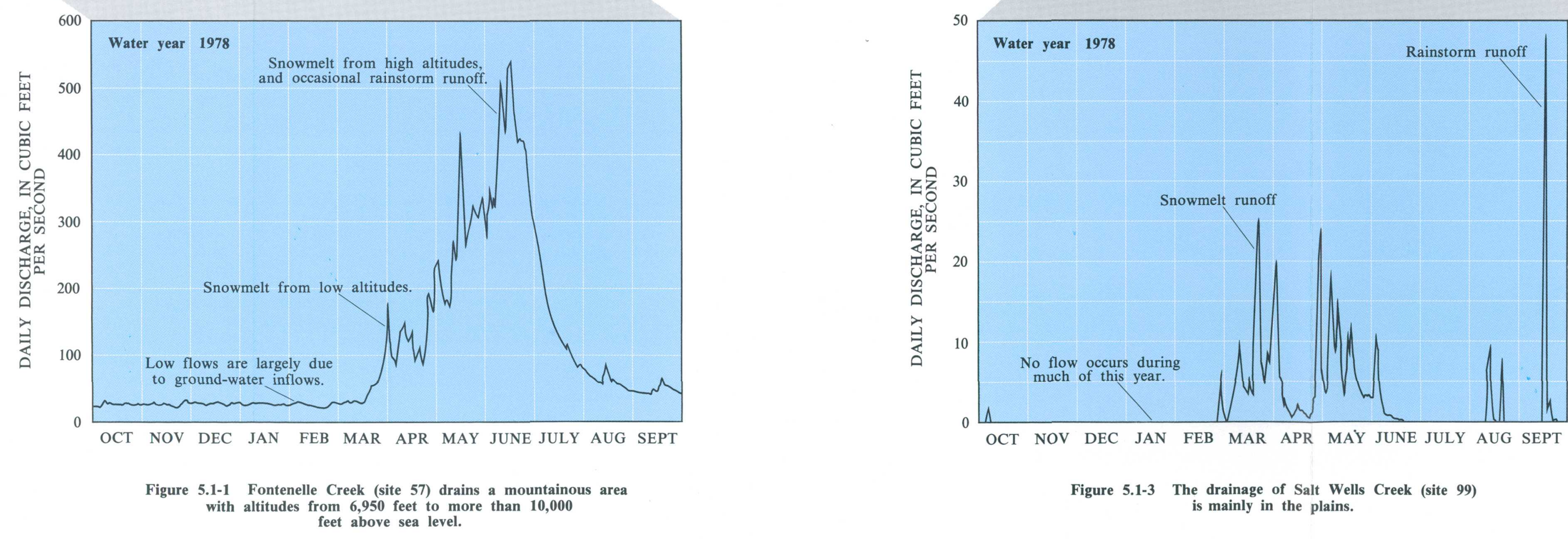

feet above sea level. 


\title{
5.0 SURFACE-WATER QUANTITY--Continued 5.2 Floodflows
}

\section{Large Floods May Result from a Combination of Deep Snowpack, Warm Air, and Rain}

\author{
Records of peak flows at gaging stations can be used to determine flood discharge. \\ When gaged data are not available, estimates are necessary.
}

Streams draining the mountainous areas generally have their largest flows during the months of May and June. The magnitude of the flow depends on the depth and water content of the snowpack that has accumulated during the preceding winter, the air temperature, and the occurrence of springtime rains. A normal warming trend in the spring causes a prolonged runoff with channels flowing near bankfull, but generally not overflowing. A warm spell, with the lowest temperatures at night above freezing, can cause over-bank flooding (fig. 5.2-1). Extremely large flows can result when there is a combination of deep snowpack, warm air, and rain.

Streams draining the plains may flood during years of exceptional snowpack; springtime rains and summertime thunderstorms also may cause floods. Large floods in the plains occur mostly during the months of May through September.

The design of bridges and culverts for road crossings, dams, diversions, and other structures on or near streams requires knowledge about the character of floods expected. If the stream has been gaged in the vicinity of the planned structure, the records of peak flows that have occurred can be used in a statistical analysis to determine the magnitude and frequency of floods. If gaging-station records are not available, then an estimate generally is made using one of several techniques that are available. For example, for design of diversions and culverts in mined areas, the Wyoming Department of Environmental Quality (1980b, p. 4) suggests use of one of the following methods: Craig and Rankl (1977), Lowham (1976), or the triangular hydrograph of the U.S. Soil Conservation Service (1972).
If the structure is temporary and will be used only for 3 years or less, the design is made on the basis of the flood that would be expected to occur once every 10 years, on the average. If the structure is to be used for 20 or more years, then a larger flood, one that would be expected to occur only once every 100 years, is used in the design. A 10-year flood is the discharge that has a 10-percent chance of being equalled or exceeded during any particular year; a 100-year flood has a 1 percent chance.

A description of a method for estimating the 100-year flood is shown in figures 5.2-2 to 5.2-4. The relations in the graphs were developed by relating floods at gaged sites to features of the respective drainage basins (Lowham, 1976). In the mountainous areas, the magnitude of the 100-year flood is dependent upon the size of the drainage area and the average basin altitude. In the plains, altitude is not a significant factor, and flood magnitude is related just to drainage area. The relations were originally developed just for Wyoming; however, data from nearby streams in adjacent states were used to extend the relations to those areas for the purpose of this report.

Areas along streams that may be subject to inundation during a flood of 100-year magnitude have been outlined on maps by the U.S. Geological Survey (fig. 5.2-5). These flood-prone area maps are available from Water Resources Division offices of the U.S. Geological Survey in Boise, Idaho, and Cheyenne, Wyo. The flood-prone area maps referred to here are not to be considered as the official delineation map for insurance purposes. Maps for that use are available from the Federal Insurance Administration located in Washington, D.C. 


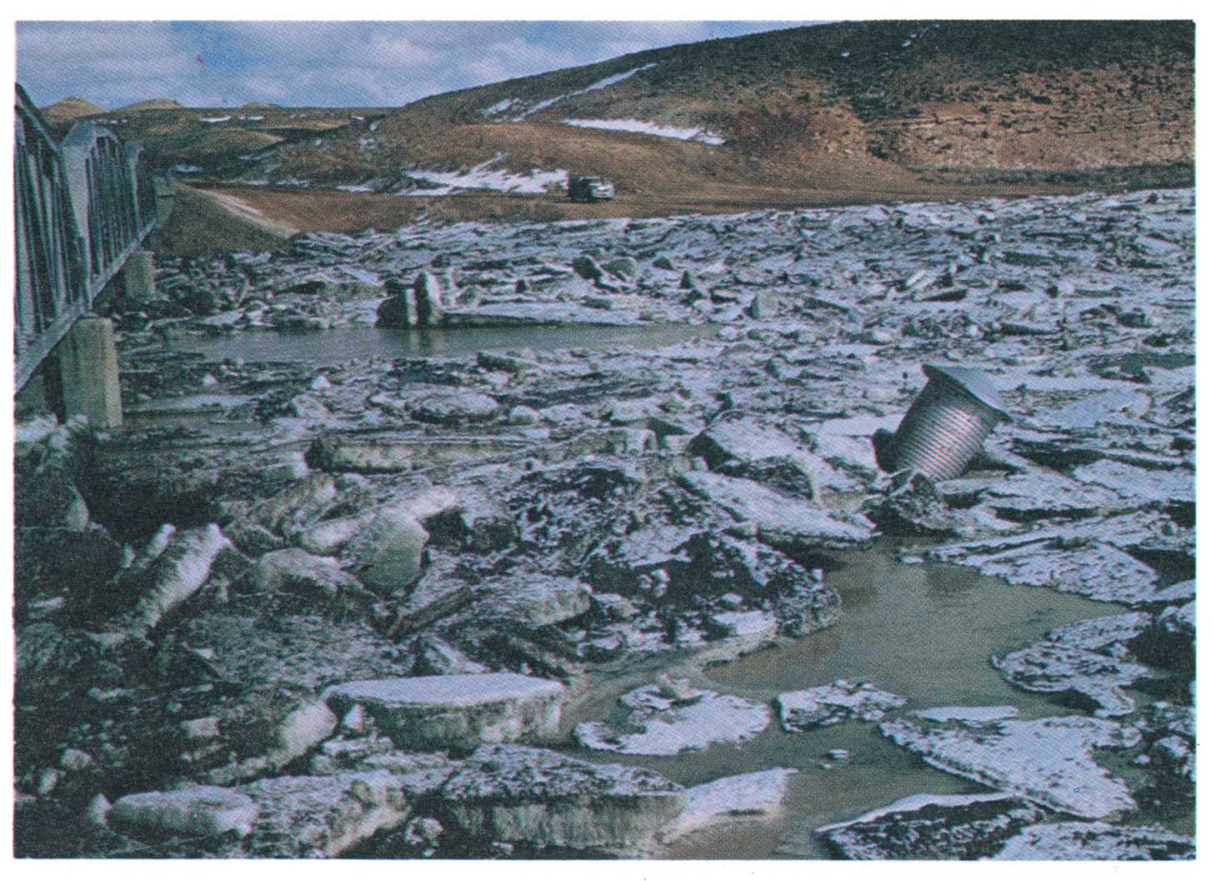

Figure 5.2-1 Floods can cause damage, as shown by this flood on
the Blacks Fork (site 144) during ice breakup of March 1962 .

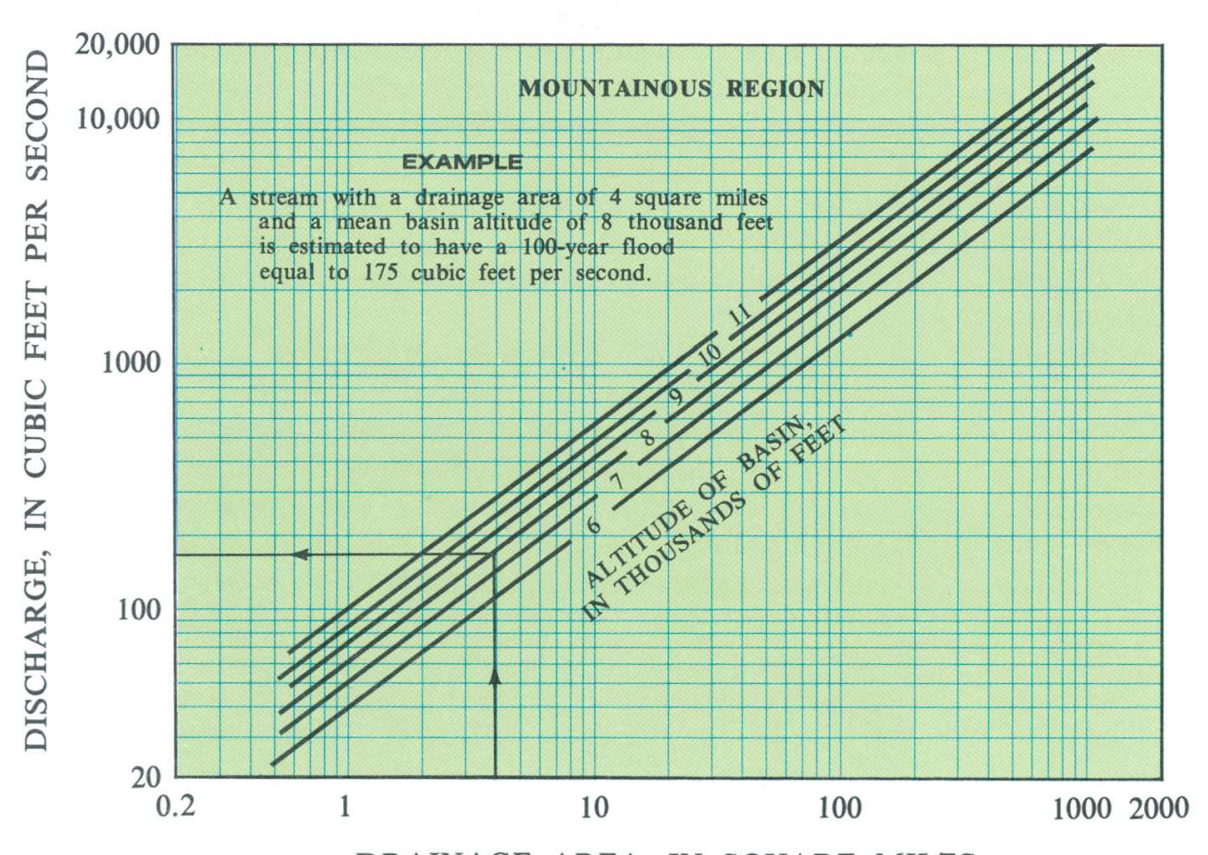

DRAINAGE AREA, IN SQUARE MULES

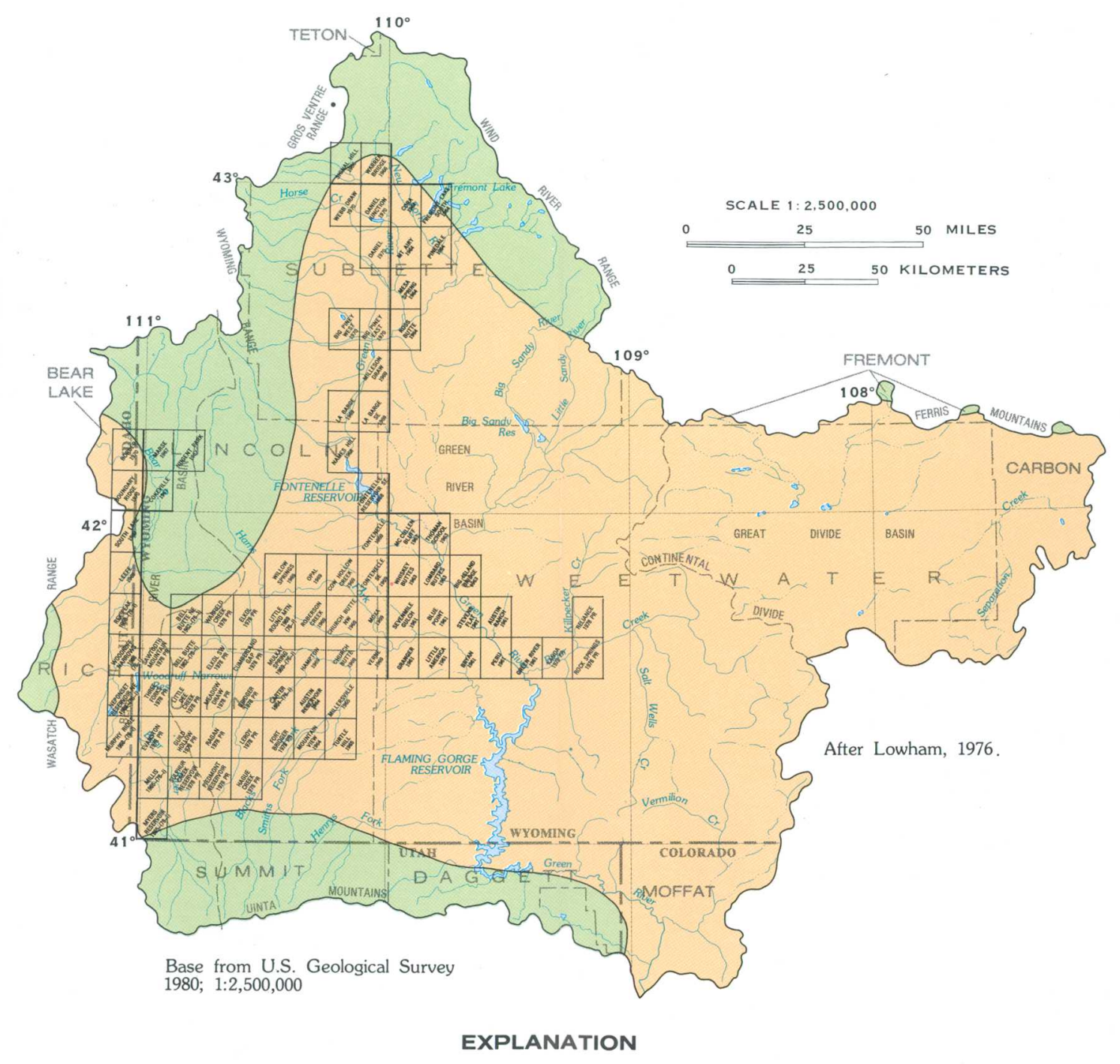

COLORED AREAS DESIGNATE GRAPH TO BE USED
TO ESTIMATE THE 100-YEAR FLOOD

$\square$ MOUNTAINOUS REgION

$\square$ PLAINS REGION

FLOOD-PRONE AREA MAP IS AVAILABLE FROM
THE U.S. GEOLOGICAL SURVEY

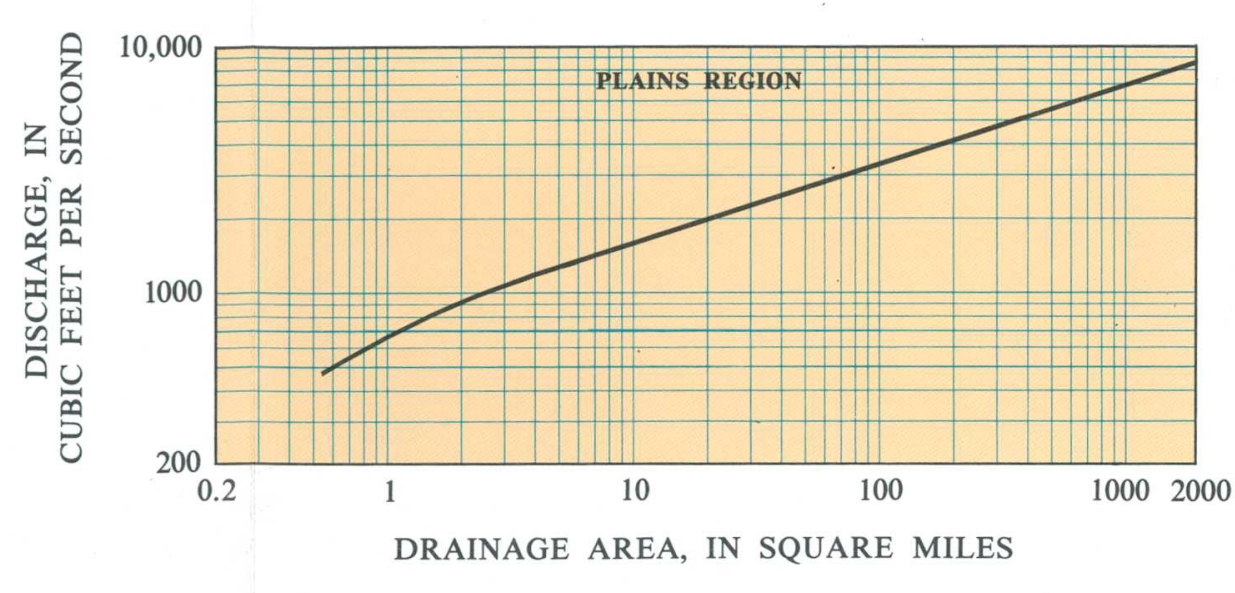

Figure 5.2-4 In the plains the 100-year flood can be estimated by
measuring the drainage area.

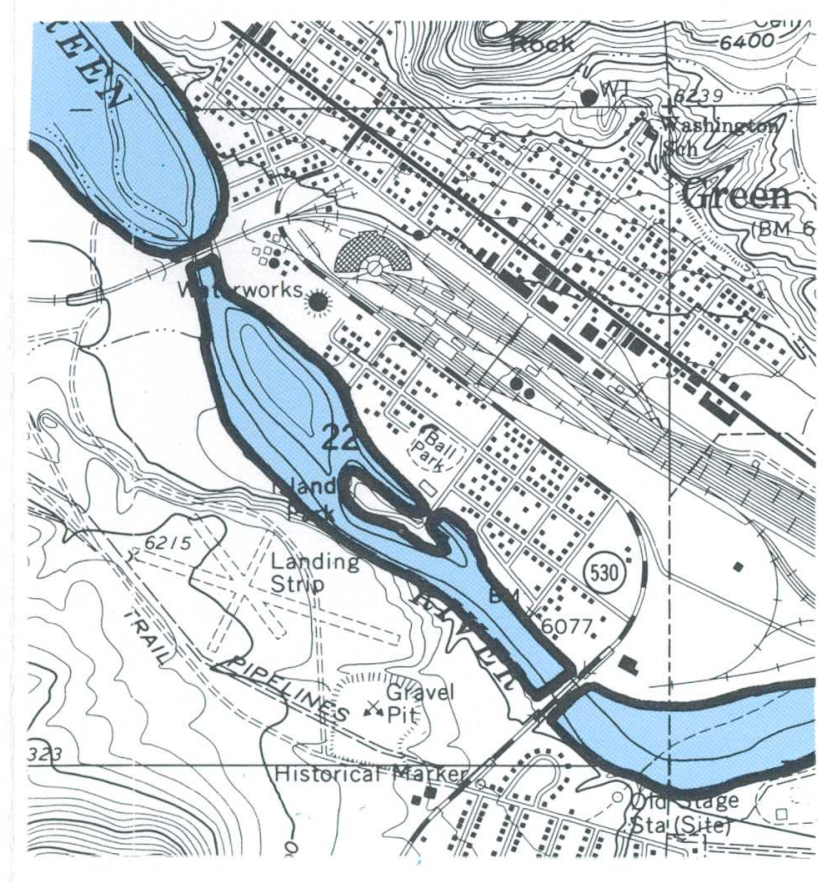

Figure 5.2-5 Flood-prone area maps are available for
many of the large streams. The blue area would be inundated by the 100 -year flood.
bould
Figure 5.2-2 In the mountainous areas, the 100-year flood can be estimated by measuring the drainage area and
the mean altitude of the basin.
Figure 5.2-3 Mountainous and plains areas, and status of flood-prone area maps. 


\title{
5.0 SURFACE-WATER QUANTITY--Continued 5.3 Average Runoff
}

\section{Runoff is Largely Dependent of Precipitation}

\author{
Major perennial streams of Area 52 originate in the mountainous areas where \\ substantial annual precipitation occurs and where ground-water discharge \\ contributes to streamflows.
}

The larger perennial streams, such as the Green River and its major tributaries, and the Bear River, originate in the mountainous areas where significant annual precipitation occurs and where geologic conditions induce ground-water inflows (figs. 5.3-1 and 5.3-2). Streams originating in the interior semiarid and arid plains areas generally are ephemeral or intermittent, and their yields are much less than those of streams draining mountainous areas. Although several of the major perennial streams flow across the plains of the area, the main source of their runoff is from the mountains. Approximate average annual runoff from the area is shown in figure 5.3-1.

The average annual runoff shown on the map is the average (or mean) value that will occur over a long period of time. The graph of annual runoff for Pacific Creek in figure 5.3-3 shows this concept.

Surface waters influenced much of the early development that occurred in the area. Fur trappers lived and worked along the mountain streams, and fur trading flourished and was responsible for much of the exploration of the area in the 1820's and 1830's. During 1840-90, many thousands of immigrants traveled across the area. Some settled on homesteads granted by the U.S. Government to encourage development of the West. During this period, many politicians and developers who lived in the East refused to realize that much of the Western land was arid and not suitable for homesteads. "Where the plow goes, the rain will follow," was a popular notion that was often stated to hopeful pioneers. Many persons actually believed that God or nature would provide rain to fields that were cultivated in arid western lands. Unfortunately, many settlers lost their life savings, and some their lives, before the notion was discarded.

The majority of the area has a runoff of less than 1 inch per year, as can be seen on the map in figure 5.3-1.
The small runoff yield occurs mainly because precipitation is low; much of the interior plains of the area receive less than 10 inches of precipitation in an average year. (See Section 2.5 for additional information on the climate.) Growing of cash or hay crops in the area of low precipitation generally is not possible or economically feasible without irrigation.

The mineable coal resources are located mainly in the arid and semiarid regions. This complicates the reclamation of mined areas, as vegetation is relatively difficult to re-establish to a degree that basin surfaces and channels are stable and resistant to erosion. The quantity of runoff that occurs in areas that are considered for mining is important to leasing and permitting decisions. For example, if a stream is considered to be perennial or intermittent, or if sufficient streamflow occurs during the growing season to support irrigation of alluvial valley floors, then special restrictions may apply to the mine plan (Wyoming Department of Environmental Quality, 1982; and the Surface Mining Control and Reclamation Act of 1977--Public Law 95-87).

The map in figure 5.3-1 showing runoff yield is very generalized, and was constructed to illustrate the relative quantities of runoff that occur in different parts of the area. More detailed and accurate information generally is needed for the analysis of a specific stream. If a gaging station has been operated on the stream, the records can provide useful information. (See Section 4.1 for information on the location of streamflow stations.) If gaging-stations records are not available, then estimating methods such as those presented by Lowham (1976) and Rantz and Eakin (1971, p. 37-61), interviewing long-time local residents, and establishment of precipitation and streamflow-gaging equipment can be used to determine water yield. 

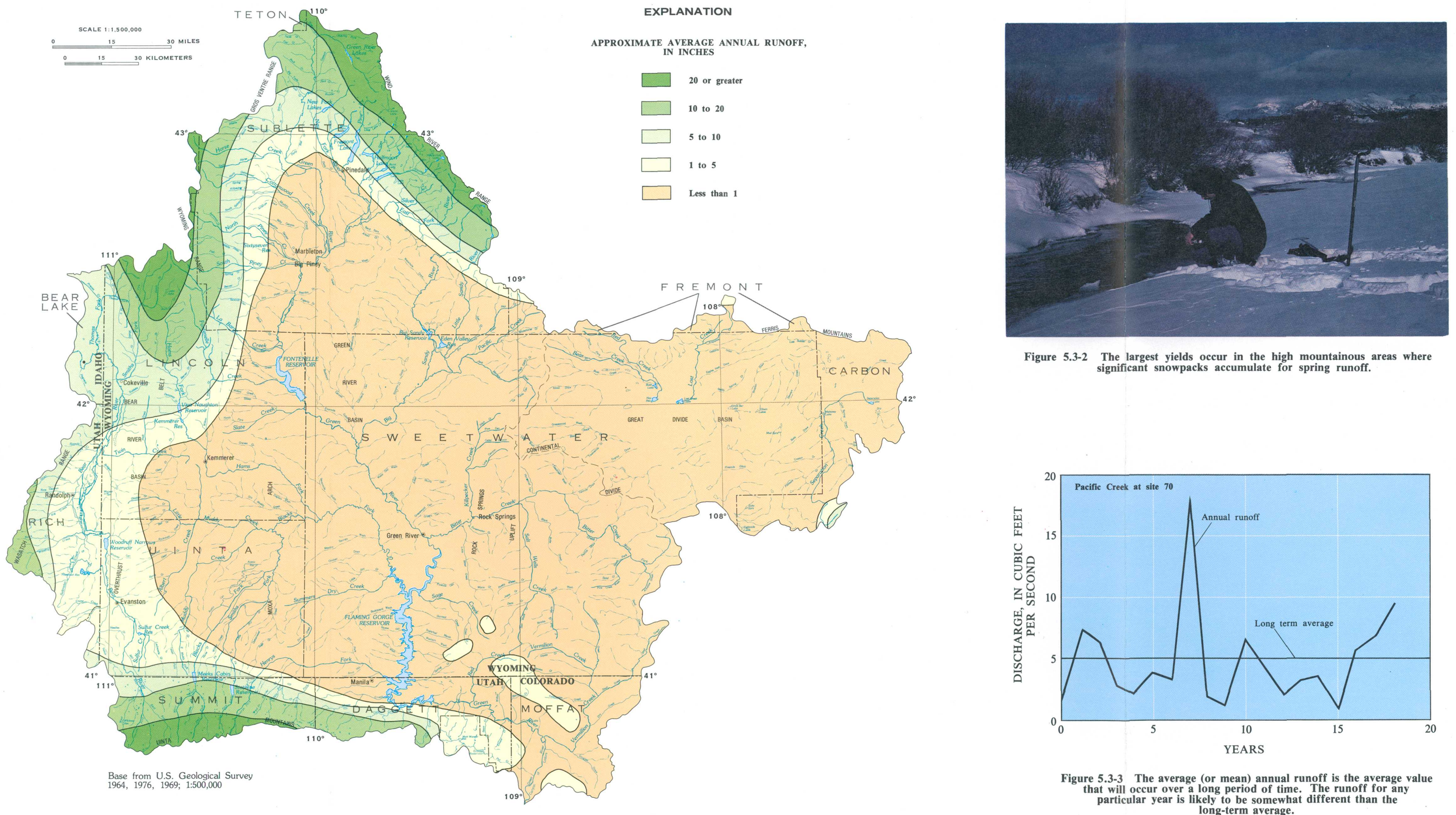

Figure 5.3-2 $\begin{aligned} & \text { The larpest yields occur in the high mountainous areas where } \\ & \text { significant snowpacks accumulate for spring runoff. }\end{aligned}$

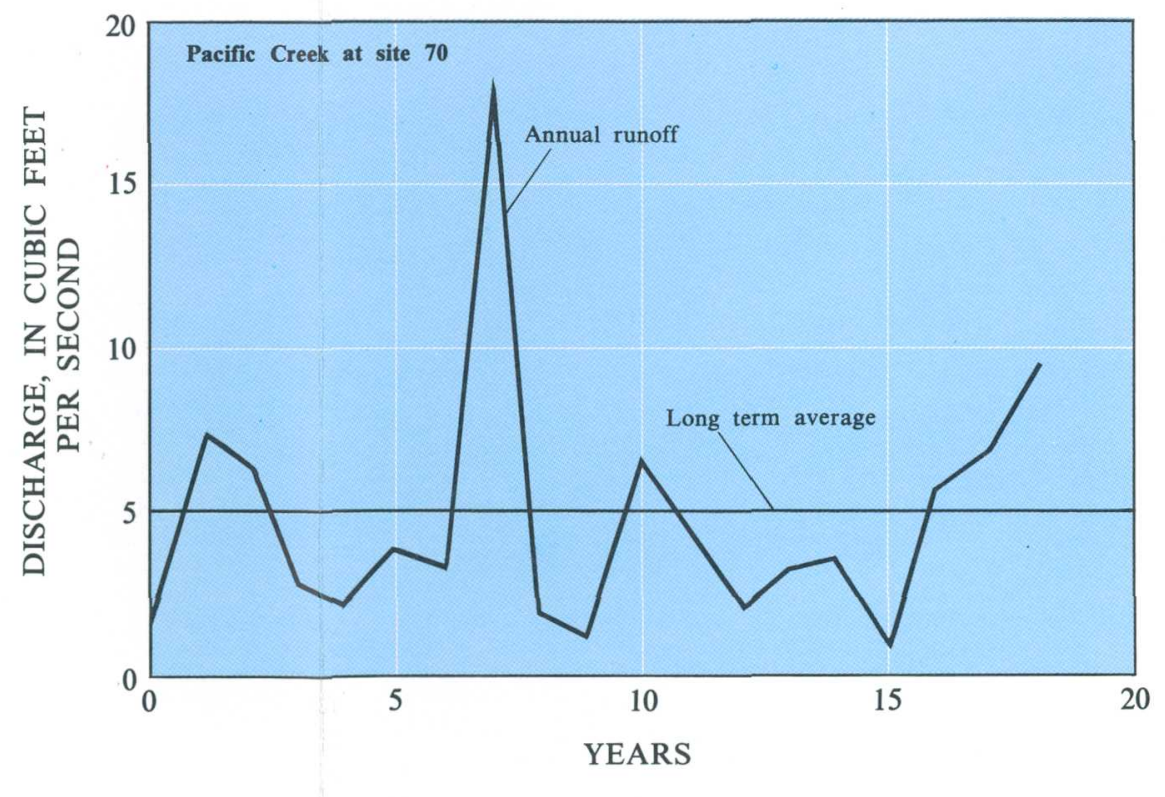

Figure 5.3.3. The average (or mean) annual runoff is the average value
that will occur over a long period of time. The runoff for any that will occur ouer 2 long period of time. The runoff for any
particular year is likely to be somewhat different than the likely to be somewhe.
long-term average. 


\title{
5.0 SURFACE-WATER QUANTITY--Continued \\ 5.4 Reservoirs and Lakes
}

\section{Reservoirs are Valuable Water Resources of the Area}

\author{
Reservoirs are used for irrigation storage, municipal and industrial supply, \\ power development, flood control, recreation, fish and wildlife habitat, \\ and storage to meet water compact demands of downstream users.
}

Many of the reservoirs in the area serve multiple uses (table 5.4-1). Water storage for irrigation is common because of the need for irrigation to grow crops. Industrial demand for water stored in reservoirs includes supply for two coal-fired powerplants in the area. Hydroelectric power is generated at two dams. All of the reservoirs are used incidentally, if not more often, for flood control, recreation, and fish and wildlife habitat. Reservoir storage helps meet allocations of water mandated by the Colorado River Compacts of 1922 and 1948, the Bear River Compact of 1955, and the Colorado, Tijuana and Rio Grande Treaty of 1944. These agreements are reprinted in Rechard and Ragsdale (1971).
Major reservoirs and lakes in the area are shown in figure 5.4-1. Many of the reservoirs in the mountainous fringes of the area such as Fremont Lake Reservoir and Boulder Lake Reservoir, are glacially formed lakes and storage was increased by construction of dams. Relatively few naturally formed lakes occur in the plains, compared to the mountains. The lakes shown by dashed lines on the map are playas, or ephemeral lakes. Small manmade reservoirs for stock watering are scattered throughout the plains.

Table 5.41. Use of reservoirs with design capacity greater than 10,000 acre-feet.

[Modified from the Wyoming State Engineer, 1970, p. 18-22]

\begin{tabular}{ll}
\hline Reservoir & Use \\
\hline Flaming Gorge & $\begin{array}{l}\text { Irrigation, hydroelectric power } \\
\text { Fontenelle }\end{array}$ \\
$\begin{array}{c}\text { Irrigation, hydroelectric power, domestic, } \\
\text { industrial }\end{array}$ \\
Woodruff Narrows & Irrigation, stock, domestic \\
Viva Naughton & Irrigation, domestic, industrial, municipal \\
Big Sandy & Irrigation \\
Meeks Cabin & Irrigation \\
Boulder Lake & Irrigation, domestic \\
New Fork Lake & Irrigation \\
Willow Lake & Irrigation, stock, domestic \\
Eden & Irrigation, domestic \\
Bush Creek & Irrigation, stock, domestic \\
Fremont Lake & Irrigation, stock, domestic \\
\end{tabular}




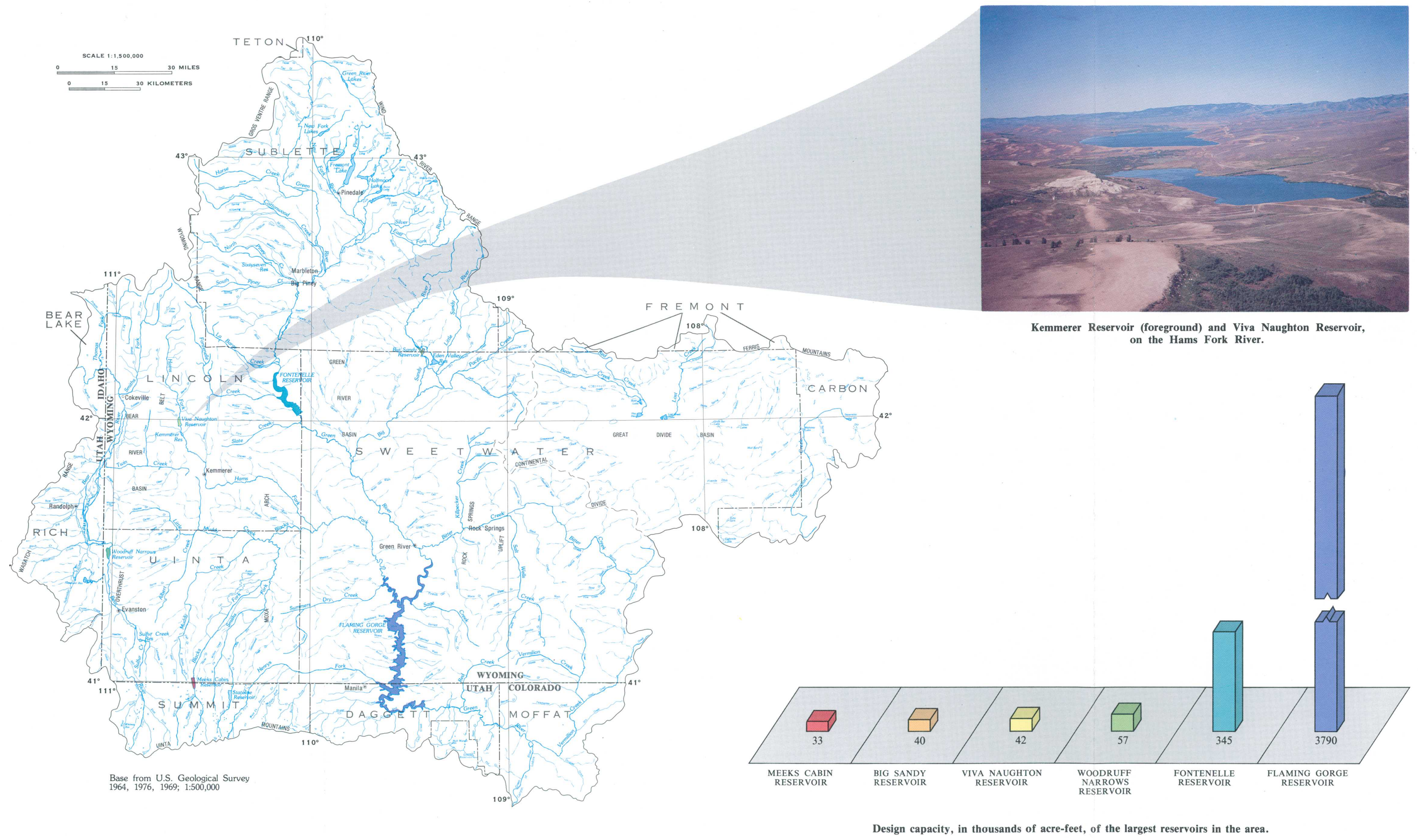




\title{
6.0 SURFACE-WATER QUALITY 6.1 Introduction
}

\section{Water Quality Good in Mountain Streams}

\author{
Chemical, sediment, and biological samples indicate good water quality in \\ mountain streams; the water quality is fair to poor in many of the plains streams.
}

The water quality of streams in or near the mountains is good for most uses (fig. 6.1-1). Concentrations of dissolved solids, phosphorus, suspended sediment, bacteria, and algae generally are small in streams originating in the mountains, compared to the concentrations found in streams originating in the plains. Types of invertebrates and fish found in the mountain streams are different from those in streams originating in the plains, partly as a result of the water-quality differences. The water quality of streams originating in the mountains generally deteriorates as they flow across the plains. The water-quality changes result from many natural and man-made causes. Natural causes include increased availability of fine materials for transport and dissolution, less shading of the water by riparian vegetation, and less runoff per unit area in the plains than in the mountains to dilute soil salts. Man-made causes include irrigation return flow, livestock grazing, municipal sewage effluent, and industrial practices.

Some of the water-quality problems, such as large concentrations of iron and manganese, caused by acid mine drainage and commonly associated with coal mining in the East are not problems in this area. Acid mine drainage is not a problem in the semiarid plains (where coal mining takes place in this area) because (1) there is little or no significant drainage from the coal mines and (2) the naturally high alkalinity of the area's soils, rocks, and waters has the ability to quickly neutralize any acid produced as a result of coal mining.

The importance of water-quality data to a determination of the probable hydrologic consequences of mining and reclamation operations is noted in Section 507(b)(11) of the Surface Mining Control and Reclamation Act. The Act also instructs the regulatory authority to assess the probable cumulative impacts of all anticipated mining in the area upon the hydrology of the area, particularly water availability. Other Federal regulations (Office of Surface Mining, 1979) set effluent limitations and specify, at the minimum, that the impact of the following be determined: dissolved solids, suspended solids, acidity, $\mathrm{pH}$, total and dissolved iron, and total manganese.

The water quality at a large number of sites has been defined by samples taken by the U.S. Geological Survey. Water-quality samples have been obtained on a systematic basis at many of the surface-water stations described in Sections 4.1 and 11.1. One or more sample results are available for the miscellaneous surface-water sites described in Sections 4.2 and 11.2. 


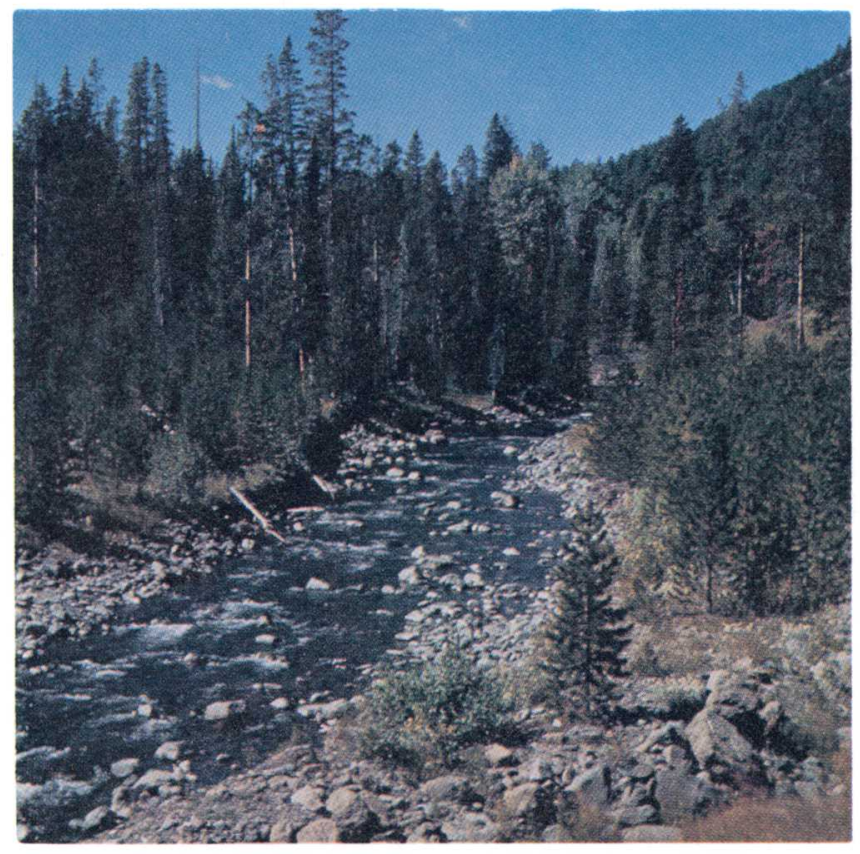

Mountain streams have "good" water quality for most uses. Photograph courtesy of the Wyoming Game and Fish Department.

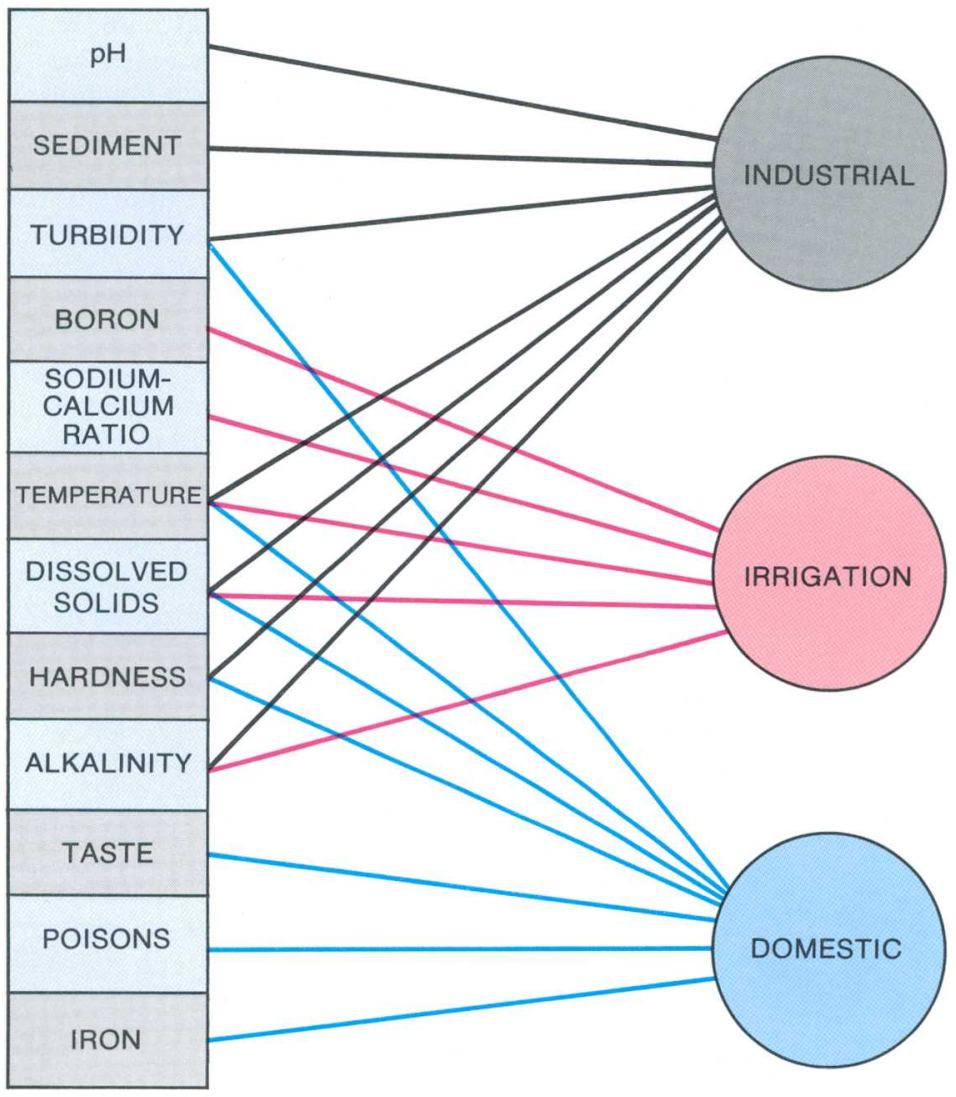

Figure 6.1-1 Water quality is judged according to its intended use. 


\title{
6.0 SURFACE-WATER QUALITY - Continued
}

\author{
6.2 Dissolved Solids
}

\section{Mountain Streams Source of Excellent Quality Water}

\author{
Snowmelt provides the Green and Bear Rivers and their mountain tributaries with a large \\ and relatively dependable supply of fresh water. However, natural processes and \\ the activities of man tend to increase the dissolved-solids concentration as \\ the water flows downstream. Streams draining the semiarid plains \\ have relatively high dissolved-solids concentrations.
}

\begin{abstract}
Dissolved-solids concentration is a measure of material dissolved in water. In much of this nation the dissolved-solids concentration of surface water is not a problem. The median dissolved-solids concentration of rivers representing 90 percent of the total national streamflow reported by the National Academy of Sciences and National Academy of Engineering (1973) is $169 \mathrm{mg} / \mathrm{L}$ (milligrams per liter). However, in the arid and semiarid West, dissolved-solids concentration is the major water-quality problem. The limited supply of fresh water (low dissolved-solids concentration) is in great demand by agriculture, municipalities, and industry.
\end{abstract}

The Green River is the major tributary of the Colorado River which supplies surface water to much of the arid Southwest. Although the salinity (dissolved-solids concentration) of the Green River is not a local problem, any practice that increases the dissolved-solids concentration or decreases the flow of the Green River tends to increase the salinity of the lower Colorado River where salinity is a water-quality problem of major economic importance.

The criteria for evaluating water quality in terms of dissolved-solids concentration are dependent upon the use of the water. A maximum concentration of $500 \mathrm{mg} / \mathrm{L}$ is recommended (U.S. Environmental Protection Agency, 1979 , p. 42198) for public water supplies. Irrigation water is classified (National Academy of Sciences and National Academy of Engineering, 1973, p. 335) as follows:

\section{Classification}

Dissolved-solids

concentration (in Water for which no detrimental are
usually noticed. milligrams per liter)

Water that can have detrimental Less than 500

effects on sensitive crops.

Water that can have adverse effects

$500-1,000$

on many crops; requires careful

management practices.

Water that can be used for tolerant

plants on permeable soils with

careful management practices.

Industrial requirements vary by industry but, in general, low dissolved-solids concentrations are desirable and in some cases mandatory.

Statistical summaries of dissolved-solids concentrations of streams in the area are graphically portrayed in figure 6.2-1. Median, maximum, minimum, and ranges in concentrations which include 50 percent and 90 percent of the samples are shown as labeled in the figure explanation. The period summarized is from October 1966 to present (1983). At least 20 samples at a station were required for the data to be included in the summary. If long-term, average streamflow is available, the average streamflow also is shown for the site.

The principal source of streamflow in the area is snowmelt from the deep mountain snowpack that accumulates during the fall, winter, and of less than 500 $\mathrm{mg} / \mathrm{L}$ are all mountain streams in the sense that their source of water is primarily from the mountains even though the site may not be located in the mountains. The upper drainages of the mountain streams have not been sampled frequently enough to be summarized in figure 6.2-1. However, the extremely low dissolved-solids concentrations of these upper drainages is indicated by the 11 samples collected at site 17 . The maximum dissolvedsolids concentration was $26 \mathrm{mg} / \mathrm{L}$, the median $13 \mathrm{mg} / \mathrm{L}$, and the minimum $8 \mathrm{mg} / \mathrm{L}$.

Dissolved-solids concentrations tend to increase as the water flows downstream out of the mountains and onto the semiarid plains. Activities of man, such as irrigation, storage, and waste disposal accelerate the natural downstream enrichment of dissolved solids in streams. The median dissolved-solids concentration of the Green River more than doubles between sites 54 and 169 . The large dissolved-solids loads contributed by the Big Sandy and the Blacks Fork Rivers are two of the principal causes for this increase.

Bitter Creek drainage is one of the few major drainages in the area lacking inflow from the mountains. The names of the streams in this drainage (Bitter Creek, Killpecker Creek, and Salt Wells Creek) are indicative of their water quality. Dissolved-solids concentrations of these streams are high except during infrequent periods of high streamflow (Lowham and others, 1982). The dissolved-solids concentration of samples from Killpecker Creek at site 100 ranges from $1,210 \mathrm{mg} / \mathrm{L}$ to $15,000 \mathrm{mg} / \mathrm{L}$. Although the dissolved-solids concentrations of Bitter Creek drainage generally are high, the salt load from this drainage into the Green River is not large because runoff of the stream generally is small. 

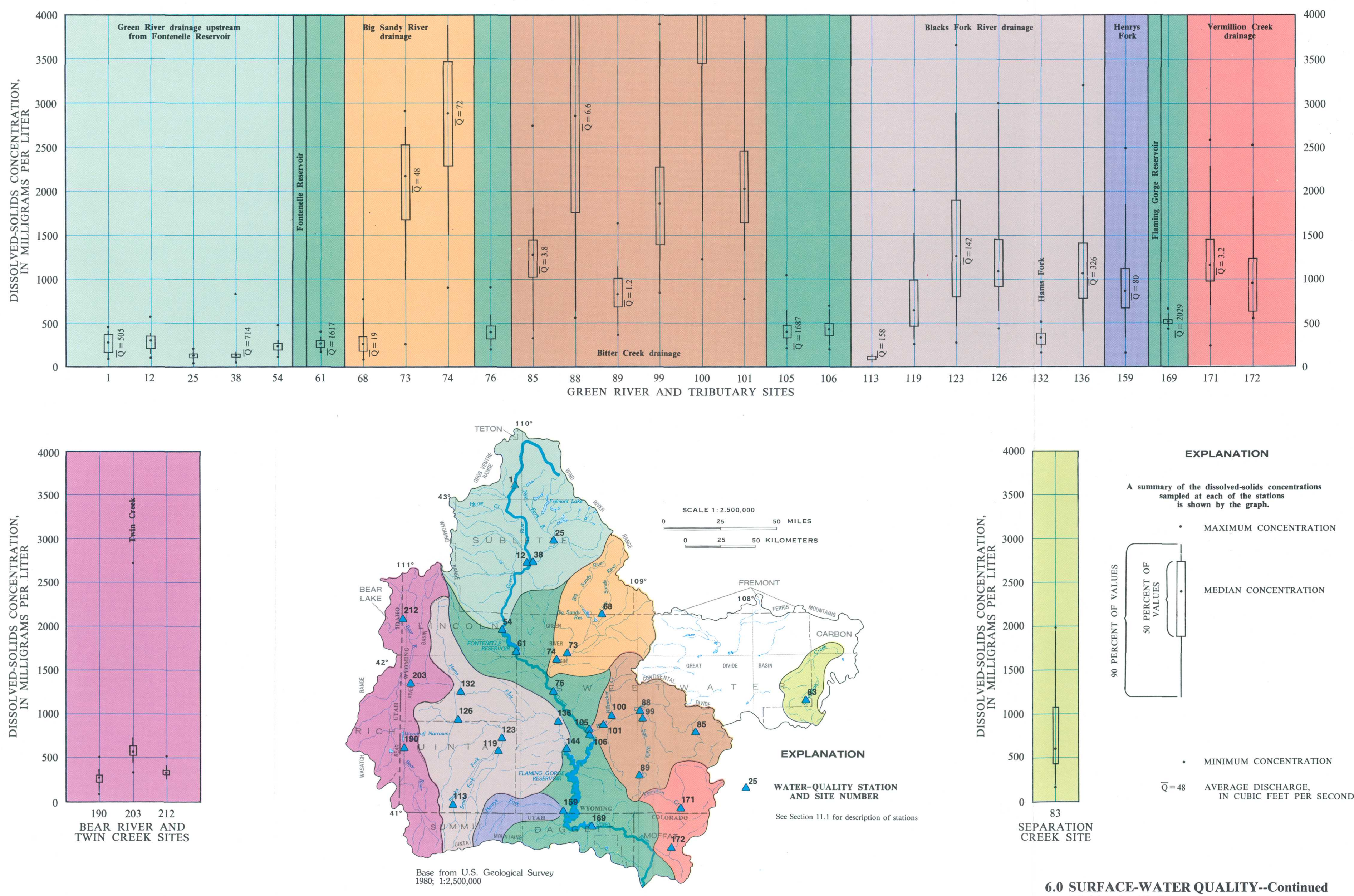

Figure 6.2-1 Dissolved-solids concentrations of streams. 


\subsection{SURFACE-WATER QUALITY--Continued $6.3 \mathrm{pH}$}

\section{Streams of the Area Slightly Alkaline}

\section{Nearly all stream $\mathrm{pH}$ measurements are above 7, and nearly all meet recommended criteria. Acid mine drainage is not a problem.}

\begin{abstract}
Measurements of $\mathrm{pH}$ are routinely made at surfacewater stations whenever water-quality samples are obtained. A frequency distribution of over $3,700 \mathrm{pH}$ measurements for streams of the area shows the water tends to be slightly alkaline (fig. 6.3-1). Nearly all the measurements are within the 6.5 to 9.0 range recommended by the U.S. Environmental Protection Agency (1977c, p. 178) to protect fish and other aquatic life. A less stringent criteria, $\mathrm{pH}$ within the range of 5.0 to 9.0 , is suggested for the raw water supplied to a watertreatment plant (National Academy of Sciences and National Academy of Engineering, 1973, p. 80).
\end{abstract}

A summary of $\mathrm{pH}$ values measured at water-quality stations in the area is shown in figure 6.3-2. Unlike some coal-mining areas of the East, acid mine drainage is not a problem because: (1) Little or no ground-water seepage flows out of existing or abandoned mines into streams, and (2) the soils, surface water, and ground water of the plains area where mining occurs have the ability to neutralize a considerable amount of acid. Consequently, low stream $\mathrm{pH}$ values with the attendant trace-metal problems typical of areas with acid mine drainage have not been a problem in the area.

The $\mathrm{pH}$ of water is of concern not only for the direct effect of $\mathrm{pH}$ on water quality, but also because the toxicity of some substances is dependent on $\mathrm{pH}$. For instance, hydrogen sulfide and hydrogen cyanide both become more toxic to fish with decreasing $\mathrm{pH}$. In contrast, ammonia is ten times more lethal to fish at $\mathrm{pH}$ 8.0 than at $\mathrm{pH} 7.0$.

It should be kept in mind that $\mathrm{pH}$ is a measurement of the hydrogen-ion concentration. Pure water and all water solutions dissociate to some extent, normally producing minute concentrations of hydrogen $\left(\mathrm{H}^{+}\right)$and hydroxyl $\left(\mathrm{OH}^{-}\right)$ions. If the concentration of hydrogen ions is equal to the concentration of hydroxyl ions, the water is neutral. If the hydrogen-ion concentration is greater than the hydroxyl-ion concentration, the water is acidic. Conversely, it is basic (alkaline) if the hydroxylion concentration is greater. In a neutral solution, at 25 degrees Celsius, the concentrations of both the hydrogen and hydroxyl ions are 0.0000001 moles per liter. (A mole is the molecular weight expressed in grams.) Because the hydrogen-ion and hydroxyl-ion concentrations normally are so low, their concentrations are more conveniently expressed as $\mathrm{pH}$ and $\mathrm{pOH}$, respectively:

$\mathrm{pH}=-\log _{10}\left[\mathrm{H}^{+}\right]$; where $\left[\mathrm{H}^{+}\right]=$the hydrogen-ion concentration in moles per liter.

$\mathrm{pOH}=-\log _{10}\left[\mathrm{OH}^{-}\right]$; where $\left[\mathrm{OH}^{-}\right]=$the hydroxylion concentration in moles per liter.

Because $\mathrm{pH}$ is the negative logarithm of the hydrogen-ion activity, an increase of $1 \mathrm{pH}$ unit represents a tenfold decrease in the hydrogen-ion concentration; an increase of $2 \mathrm{pH}$ units, a hundredfold decrease; and an increase of $3 \mathrm{pH}$ units, a thousandfold decrease. Thus the permissible $\mathrm{pH}$ range of 5 to 9 (for raw water for public supplies) allows a ten-thousandfold variation in the hydrogen-ion concentration. The $\mathrm{pH}$ scale ranges from 0 to 14, with a $\mathrm{pH}$ of 7 being neutral.

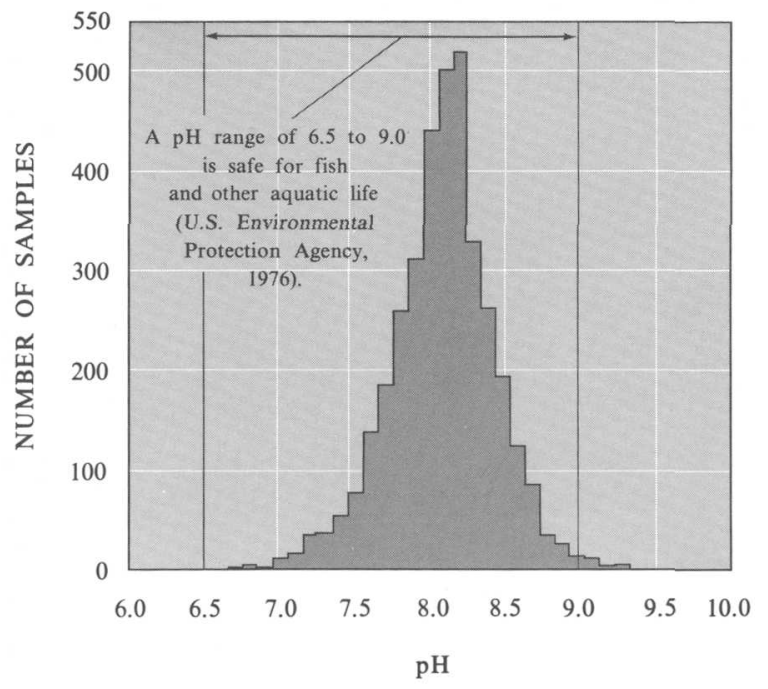

Figure 6.3-1 Histogram of $\mathrm{pH}$ values for surface-water samples. 

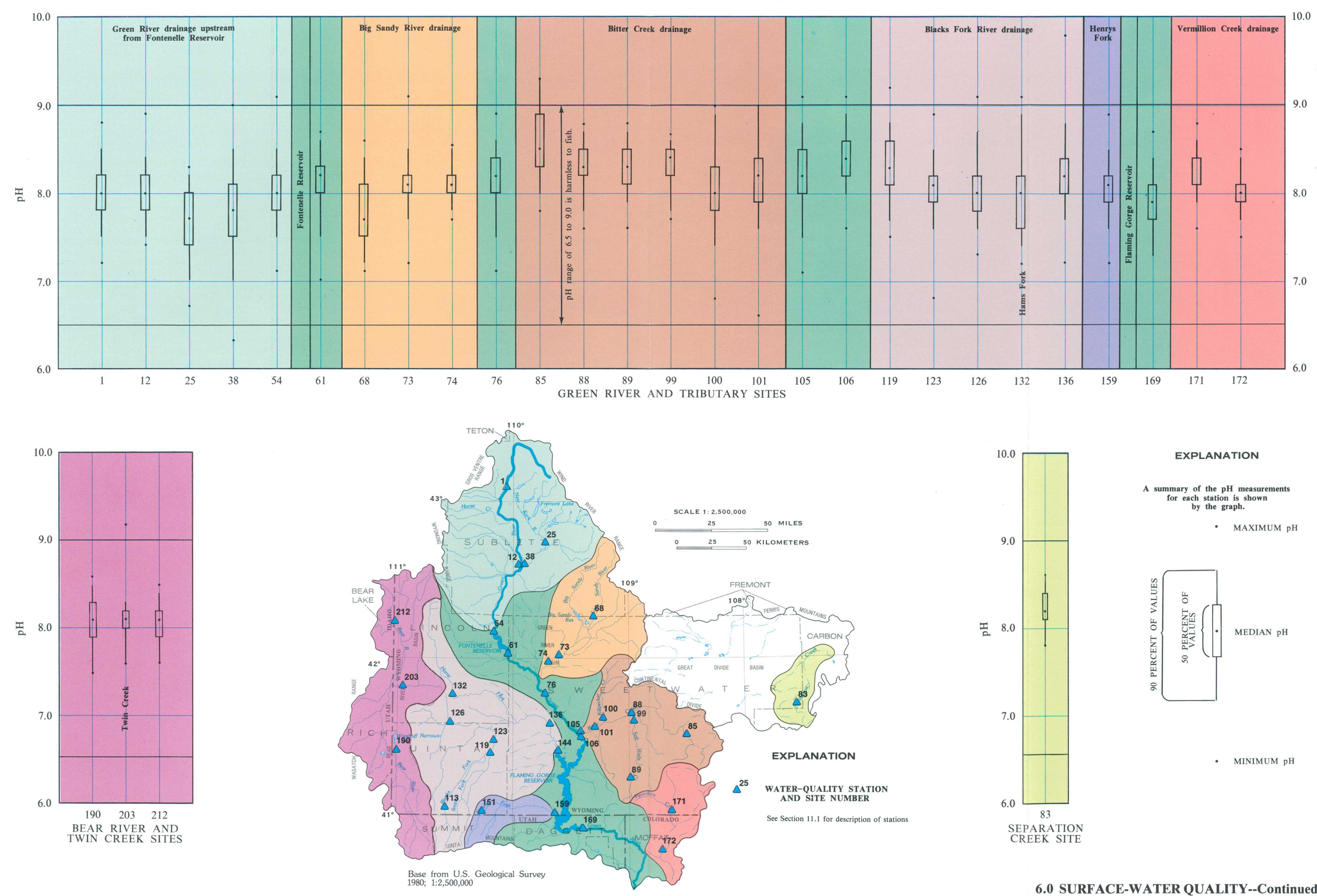

EXPLANATION

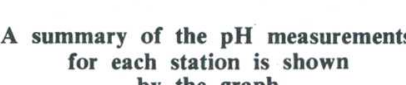

- maximum ph

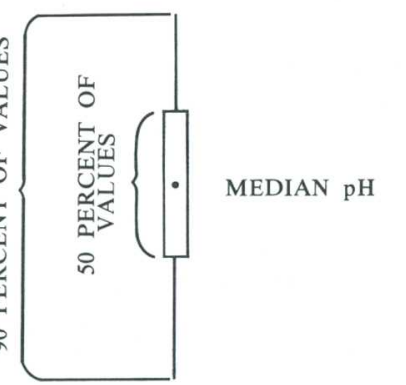

Figure 6.3-2 $\mathrm{pH}$ values of streams. 


\title{
6.0 SURFACE-WATER QUALITY--Continued \\ 6.4 Total-Phosphorus
}

\section{Total-Phosphorus Concentrations May Threaten Reservoirs}

\author{
Total-phosphorus concentrations in streams of the area frequently exceed the \\ limits recommended to protect reservoirs and streams from nuisance growth of \\ algae and other aquatic plants.
}

Phosphorus is a potential problem because of eutrophication. Eutrophication is the process which ages lakes and reservoirs. It is a natural process, normally slow, but unfortunately is often accelerated by the activities of man. One aspect of eutrophication is nutrient (primarily nitrogen and phosphorus) enrichment. Excessive nutrient concentrations stimulate nuisance growths of algae, slime organisms, and water weeds, which cause periodic oxygen depletions. Desirable fish species such as trout may be eliminated as eutrophication progresses, although some nutrient enrichment initially may be favorable for high trout productivity. Flaming Gorge Dam, used to create the major reservoir of the area, began storing water in 1962. Since then Flaming Gorge Reservoir has become a trout fishery of national repute. However, the two upper arms are eutrophic and have an inhospitable environment for trout during the summer and early fall because of low dissolved-oxygen concentrations, warm temperatures, and algal blooms. Should the eutrophic zone of the reservoir increase in size, more trout habitat within the reservoir will be eliminated.

Nutrients are essential for the growth and reproduction of aquatic life. Essential macronutrients are calcium, magnesium, sodium, potassium, sulfur, carbon, nitrogen, and phosphorus. Known essential micronutrients are silica, manganese, iron, zinc, copper, molybdenum, boron, titanium, chromium, cobalt, selenium, and perhaps vanadium. These elements are normally present (to a varying degree) in natural waters. Unless cold water temperature or the lack of sunlight restrict growth, uptake of nutrients eventually leads to the depletion of one of these essential nutrients, restricting further growth of aquatic life forms. The nutrient most frequently limiting the growth of aquatic plants is phosphorus.

To protect reservoirs from accelerated eutrophication the total-phosphorus concentrations of streams entering the reservoirs should not exceed $0.05 \mathrm{mg} / \mathrm{L}$ (milligrams per liter) and to protect the streams themselves from algal problems the total-phosphorus concentrations should not exceed $0.10 \mathrm{mg} / \mathrm{L}$ (U.S. Environmental Protection Agency, 1977c, p. 186). These criteria are both frequently exceeded by streams of the area (fig. 6.4-1), although many sites, especially those in the upper Green River Basin, have median concentrations at or below the $.01-\mathrm{mg} / \mathrm{L}$ detection limit. However, median concentrations of all streams in Bitter Creek drainage are greater than the $0.05-\mathrm{mg} / \mathrm{L}$ standard and most of the Bitter Creek sites have median total-phosphorus concentrations which exceed the $0.10 \mathrm{mg} / \mathrm{L}$ standard.

Sewage effluents are rich in phosphorus; human body wastes produce about 1 pound of phosphorus per year. An additional $3 \frac{1}{2}$ pounds per year per capita are added to sewage systems through the use of phosphate detergents and other domestic phosphates (U.S. Environmental Protection Agency, 1977c, p. 353). Any practice that increases the stream transport of sediments also increases the total-phosphorus concentration because much of the phosphorus that is transported is sorbed onto sediment particles. (Phosphorus also is naturally present in some of the parent rocks of the area.)

The effect on the Green River of sewage effluent from the cities of Rock Springs and Green River and the natural total-phosphorus load of Bitter Creek is shown by the difference between site 105 and 106 (fig. 6.4-1). The median concentration on the Green River is more than doubled, changing from $0.03 \mathrm{mg} / \mathrm{L}$ at site 105 to $0.07 \mathrm{mg} / \mathrm{L}$ at site 106 .

The two sites on the Green River which are below reservoirs (site 58 below Fontenelle and site 169 below Flaming Gorge Reservoir) show the trapping effect of the reservoirs on the incoming total-phosphorus load. Because much of the total-phosphorus is transported by stream sediment, it is trapped along with the sediment which drops out on entering the reservoir. The bottom sediments on the shallow end of a reservoir are therefore a source of phosphorus when stirred by wave action or during spring and fall turnover.

Data for the total-phosphorus concentration entering the Blacks Fork arm of Flaming Gorge Reservoir are too limited to summarize except for some upstream sites. However, the few values from the site nearest to the reservoir that are available do indicate a sizeable totalphosphorus load entering Flaming Gorge Reservoir from the Blacks Fork drainage.

Henrys Fork (average streamflow, 80 cubic feet per second) enters Flaming Gorge Reservoir near the dam. The total-phosphorus concentration of Henrys Fork frequently exceeds the recommended criterion and may pose more of a hazard to the lower reservoir than the phosphorus entering from the Green and Blacks Fork Rivers. The phosphorus from these two sources tends to be trapped in the two upper arms of the reservoir.

It is likely that a large portion of the total-phosphorus load entering Flaming Gorge and other reservoirs in the area is natural. It also is likely that activities of man such as sewage disposal, road and building construction, livestock production, off-road vehicle use, and tilling of soil have increased the total-phosphorus load transported by streams of the area. However, the significance of this increase compared to the natural total-phosphorus load is not known. 

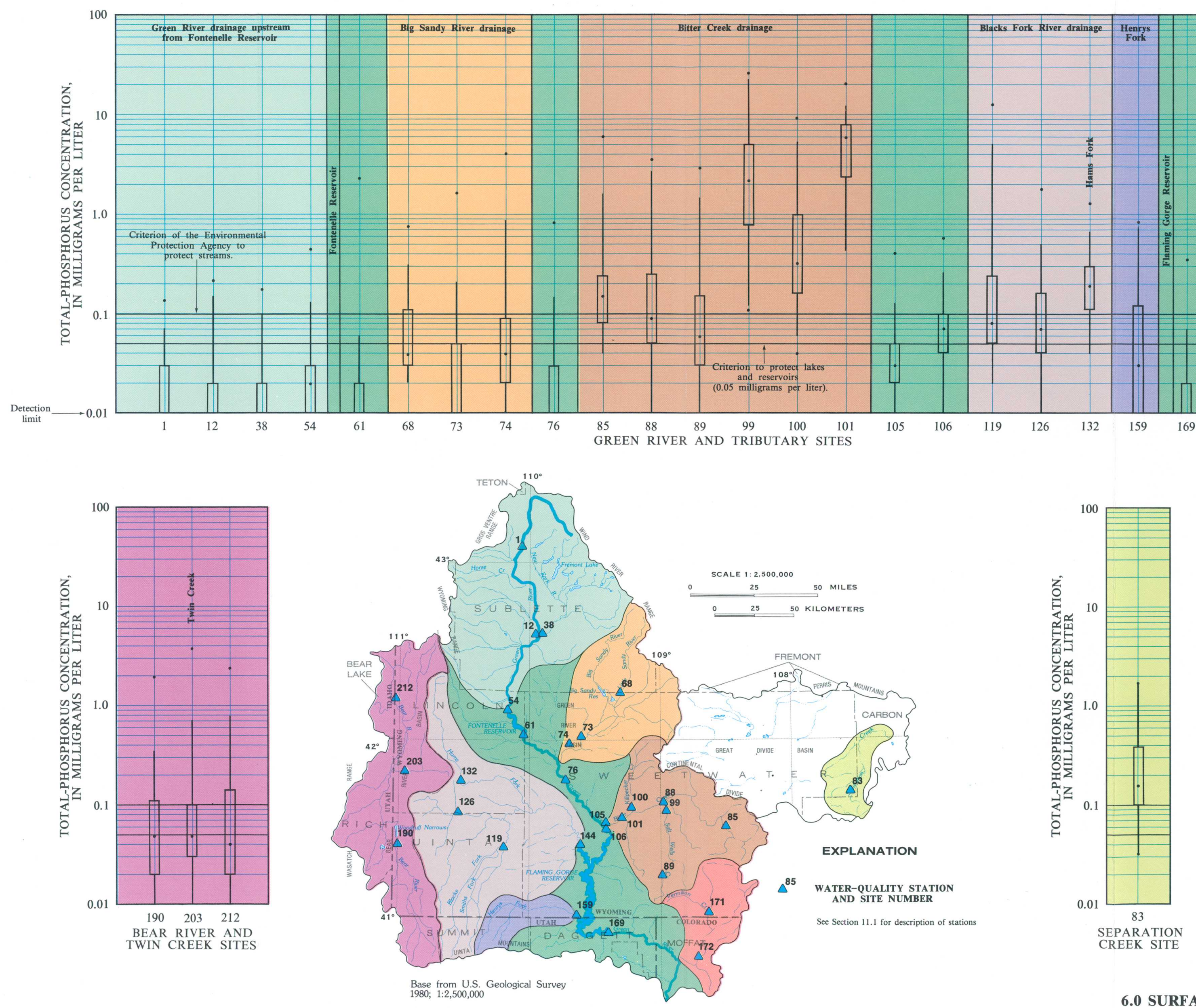

EXPLANATION
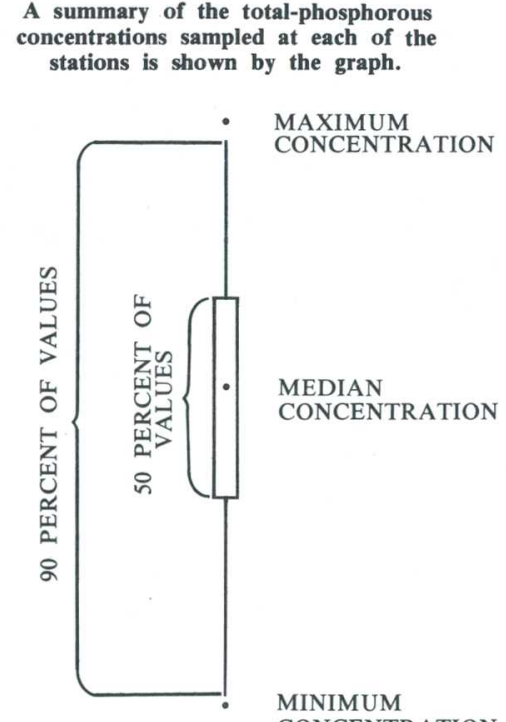

Figure 6.4-1 Total-phosphorus concentrations of streams. 


\title{
6.0 SURFACE-WATER QUALITY--Continued 6.5 Suspended Sediment
}

\section{Quantity of Fluvial Sediment Transported in Most of Area is Small}

\author{
Reservoirs are the primary reason why relatively large quantities of suspended \\ sediment are not transported out of most of the area.
}

Records collected at sites $1,38,50,54,57,61,74,105$, $136,159,169,170$, and 172 in the Green River Basin (figs. 6.5-1 through 6.5-5) show that the quantity of suspended sediment which is yielded from the drainage of the Green River above Flaming Gorge Reservoir is small and most of it is trapped in Fontenelle and Flaming Gorge Reservoirs. For example, 183,800 tons of suspended sediment were delivered by the Green River (site 54) to Fontenelle Reservoir during the 1978 water year and only 10,800 tons passed through the reservoir (site 61). (Data for all stations were available for the 1978 water year. Streamflows during the 1978 water year were 120 percent of the 32-year average.) Similar, but more pronounced effects, may be seen in Flaming Gorge Reservoir where a combined total of 549,000 tons was brought to the reservoir by the Green River, (site 105), Blacks Fork (site 136), and Henry's Fork (site 154) but only 400 tons were measured below the dam outlet (site 169). In contrast, more than 470,000 tons of suspended sediment were delivered to the short reach of the Green River between Flaming Gorge Dam and the mouth of the Yampa River by Red Creek (site 170) and Vermillion Creek (site 172). A schematic representation of this effect is shown in figure 6.5-5.

Records show that 64,600 tons of suspended sediment passed down the Bear River at site 213 during the 1978 water year, 13,500 of which came from Twin Creek, site 203. This suspended sediment eventually is deposited in Dingle Swamp at the north end of Bear Lake in Utah. During the 1978 water year, 437 tons of suspended sediment were measured in Separation Creek (site 83) in the Great Divide Basin. This stream is typical of those in that basin as it is ephemeral and sediment carried by it is brought to the center of the basin and deposited on a lakebed.

The records also show that the suspended sediment in transport in both the Green River and Bear River Basins is, on the average, composed of 54 percent clay (particles with diameters smaller than 0.004 millimeters), 35 percent silt (particles with diameters between 0.004 and 0.062 millimeters) and 11 percent sand (particles with diameters larger than 0.062 millimeters). The suspended sediment in transport in the Great Divide Basin is, on the average, composed of 68 percent clay, 32 percent silt, and no sand. The pie diagrams in figure 6.5-3 give a basin-to-basin comparison of this size distribution.

Streams transport sediment as a natural-occurring process. Any substantial and persistent change in the quantity of sediment being transported has the potential for affecting the environment. Some examples of these effects include: (1) Suspended sediment is the major cause of turbidity that blocks sunlight to aquatic lifeforms and also reduces the aesthetic quality of the water (Brown and Ritter, 1971, p. 60-61); (2) the deposition of fine sediments in voids between sand and gravel particles ruins an area as a habitat for invertebrates and fish eggs (James and Evison, 1979, ch. 2, p. 7); (3) chemicals sorb to the surface provided by sediment particles and form chemically enriched sinks where that sediment is deposited (Hem, 1970, p. 36-37); and (4) the potential for erosion by the flowing water is increased or decreased as the quantity of suspended sediment carried by that water is decreased or increased (Colby, 1963, p. 8).

Many variables affect the sediment system and no simple method exists for accurately describing concentrations, loads, or particle-size distribution of the suspended sediment produced and transported out of an area as large as, and having the diverse physiographic and hydrologic conditions of Area 52. In lieu of a comprehensive description, the sediment characteristics instead may be described as at-a-site and then compared site-to-site as is done by the curve on the graph in figure 6.5-2. These curves illustrate the following: (1) As water discharge increases, concentration also increases, (Colby, $1956, p .10-13),(2)$ the inflow characteristics of suspended sediment to both Fontenelle and Flaming Gorge Reservoirs are similar as is outflow although the outflow is considerably less than inflow; and (3) the concentration at site $\mathbf{1 7 2}$ is much higher at low flows and increases at a much faster rate with discharge than at the other stations.

Land-use activities such as logging, road construction, and surface mining have the potential to drastically increase sediment loading of streams while reservoir storage will decrease it. In surface mining, large areas of loose material and unvegetated land surface are susceptible to erosion. The eroded material has the potential to wash into streams; however, during mining and until reclamation is satisfactorily accomplished, the regulatory agencies generally require sediment control structures such as sediment ponds (Wyoming Department of Environmental Quality, 1982, p. 69). Studies which identify the antecedent conditions, measure the effectiveness of on-site controls, and evaluate the mitigating measures to determine if follow-up changes are needed are a necessary part of any land-use plan. 


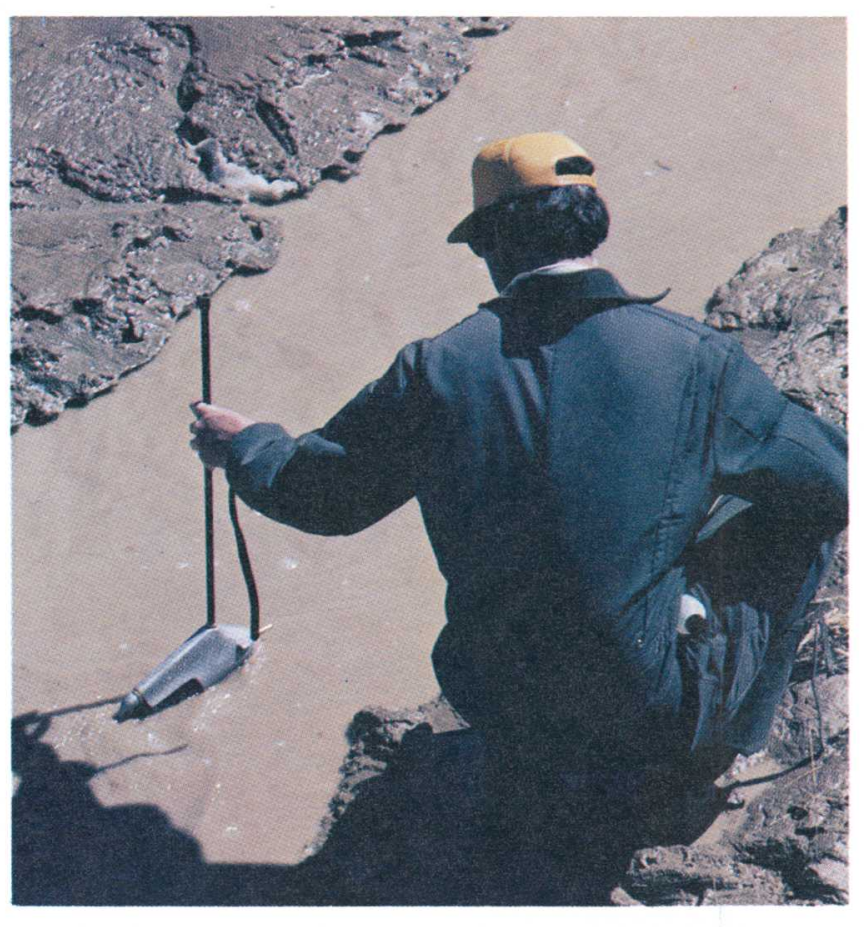

Figure 6.5-1 Collecting a sample for
suspended sediment analysis.

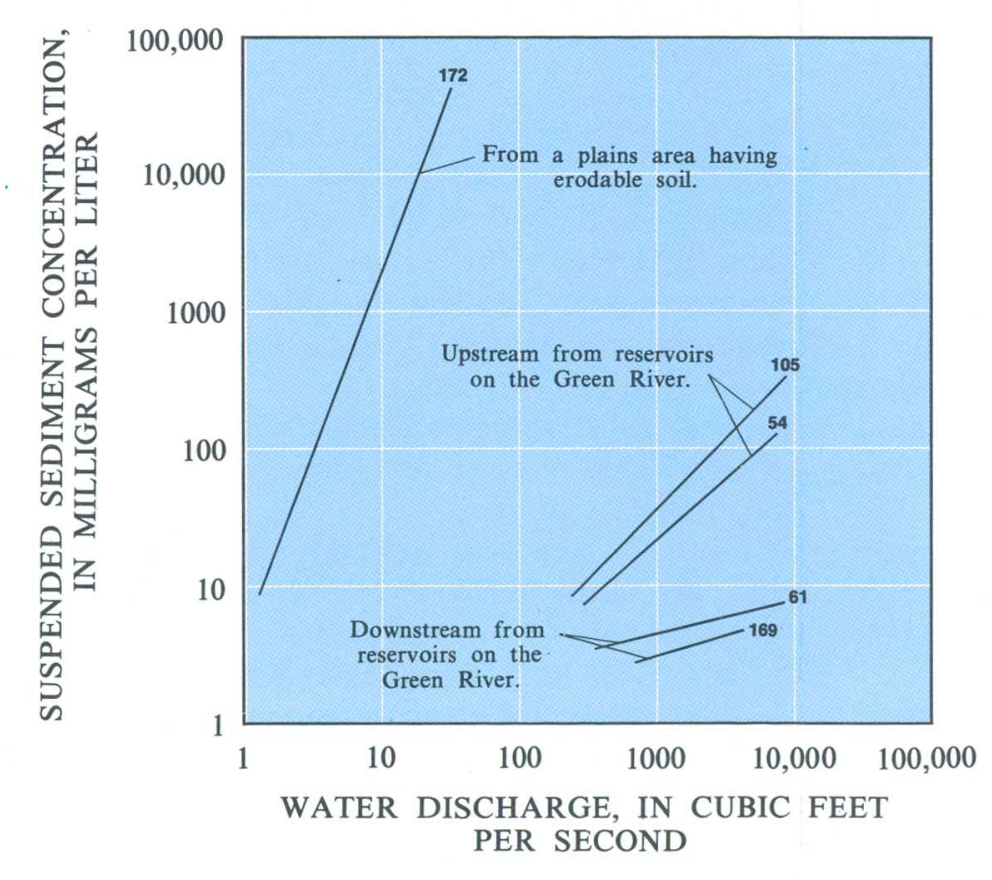

Figure 6.5-2 Suspended-sediment concentration usually increases as quantity
of streamflow increases.

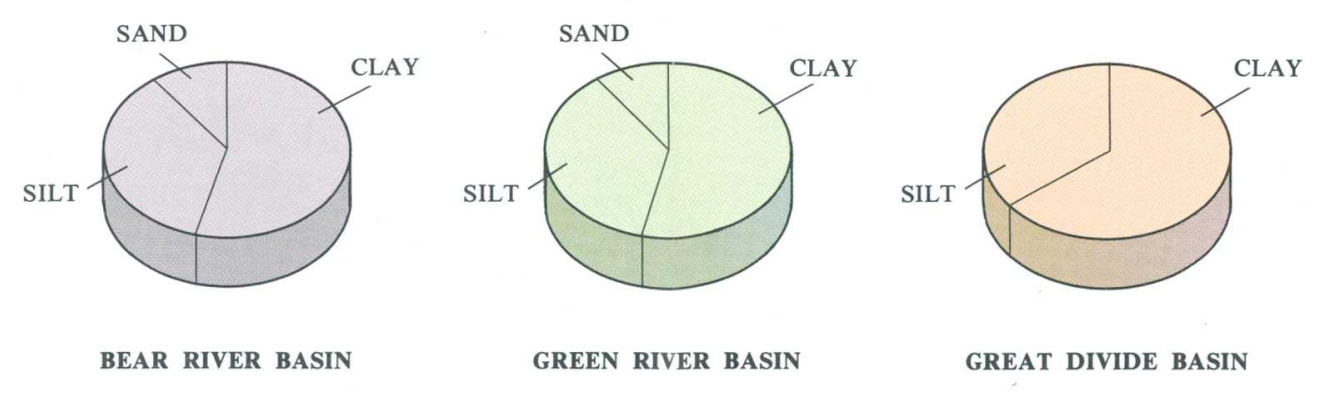

Figure 6.5-3 Average composition of suspended sediment.

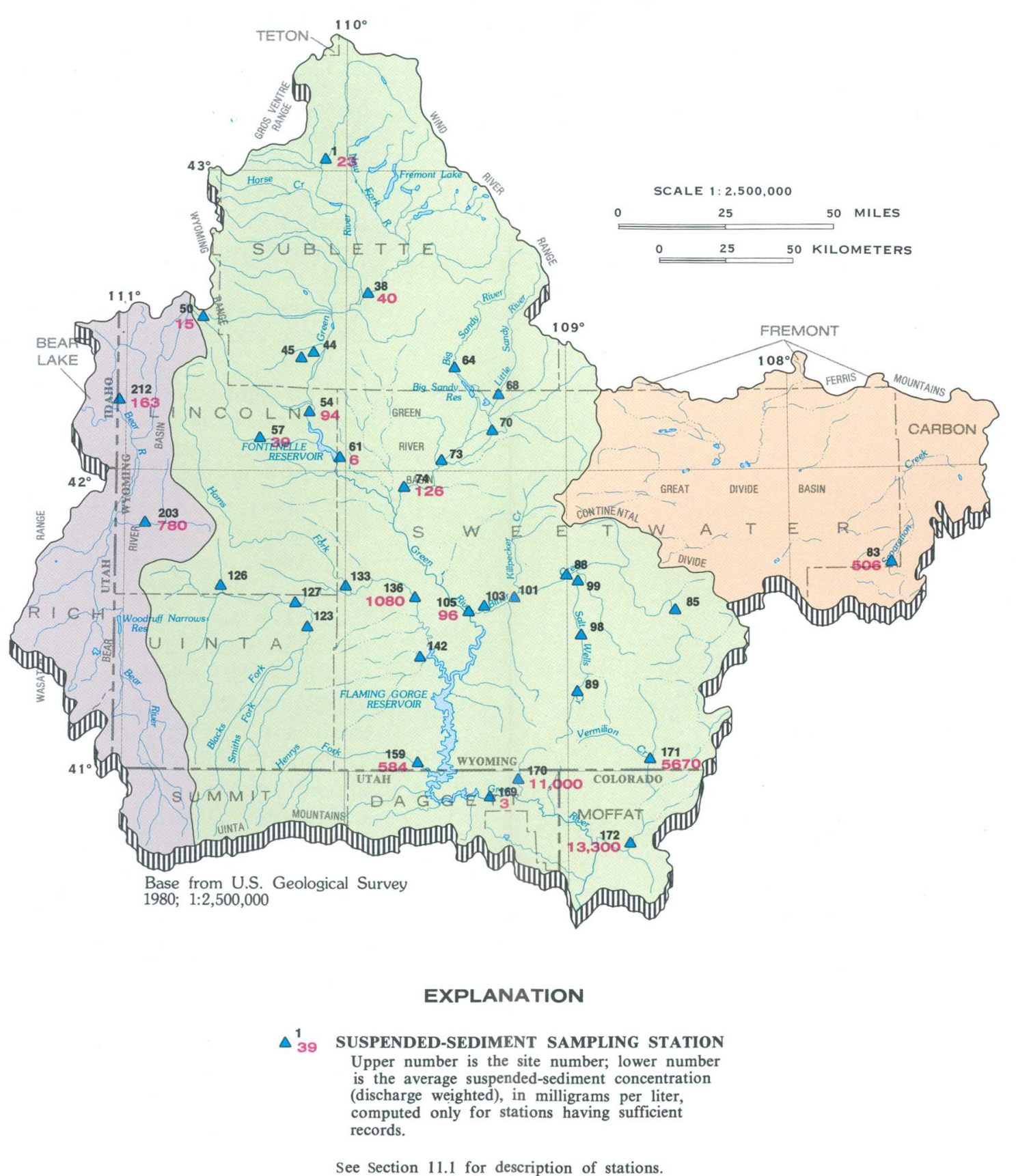

Figure 6.5-4 Sampling and analysis of suspended sediment in streamflows.

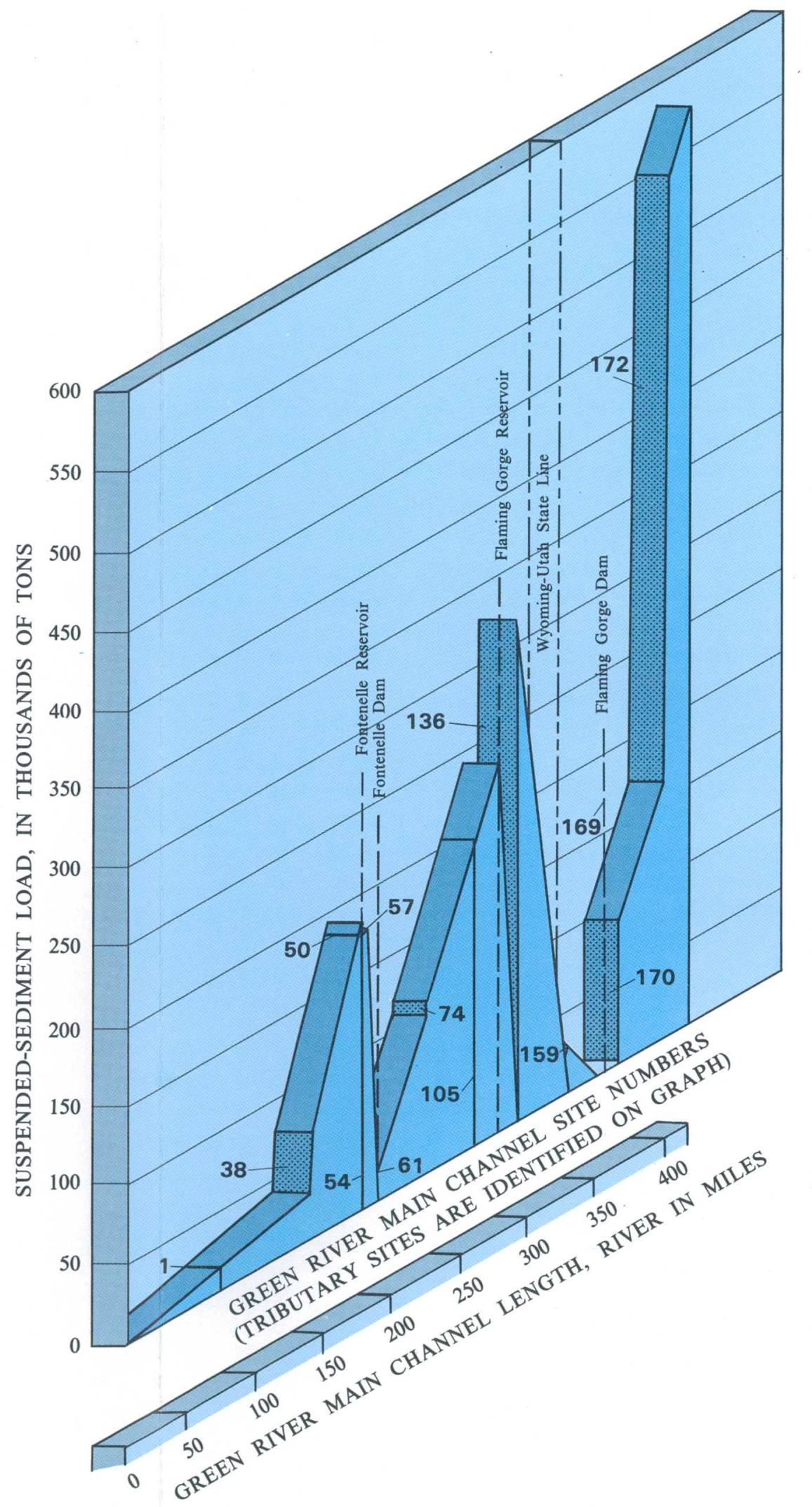

Figure 6.5-5 Suspended-sediment loads of the Green Riverwater year 1978

6.0 SURFACE-WATER QUALITY--Continued 6.5 Suspended Sediment 


\title{
6.0 SURFACE-WATER QUALITY--Continued 6.6 Bacteria
}

\section{Bacteria Concentrations are Small in Most Streams}

\author{
Small concentrations of fecal coliform bacteria indicate little pollution from \\ warm-blooded animals.
}

The two primary sources of fecal coliform bacteria in streams of the area are fecal waste from livestock and wildlife, and human waste from sewage plants or individual septic systems. Because there are relatively few people and livestock in the area, fecal pollution contributed to streams by humans and animals is small. The probable sources of fecal bacteria in most streams are fecal wastes of livestook and wildlife that graze in the area and drink from streams.

The logarithmic mean fecal coliform bacteria concentration is less than 200 colonies per 100 milliliters of water at 12 of the 16 stations that were sampled (fig. 6.6-1). The logarithmic mean, also known as the geometric mean, is the antilogarithm of the mean of the logarithms. The logarithmic mean is a better measure of the "middle" value of bacteria data, than is the arithmetic mean. The fecal coliform bacteria level should not exceed a logarithmic mean of 200 colonies per 100 milliliters in bathing waters (swimming, water skiing, etc.), based on not less than five samples in 30 days (U.S. Environmental Protection Agency, 1976, p. 79). The coliform bacteria level should not exceed an arithmetic mean of one per 100 milliliters in drinking water (U.S. Environmental Protection Agency, 1975, p. 59571). Drinking-water supplies from surface water often are chlorinated to meet the standard.

The largest logarithmic mean fecal coliform bacteria concentration was 365,000 colonies per
100 milliliters, in Bitter Creek at site 101. The large bacteria concentration in Bitter Creek is due to municipal sewage effluent. The logarithmic mean concentration in the Green River was 89 colonies per 100 milliliters at site 105 , above the mouth of Bitter Creek, compared to 517 colonies per 100 milliliters at site 106 , below the mouth of Bitter Creek.

Fecal coliform bacteria originate in the gastrointestinal tract of warm-blooded animals, and are not adapted to aquatic environments. Their presence does not constitute a health hazard; they are sampled as indicators of the possible presence of pathogens, or disease-causing organisms. The half-life (length of time during which one-half of the remaining bacteria are destroyed) of fecal coliform bacteria outside the gastrointestinal tract is from one to three days (Mallard, 1981, p. E29-E32). The distance of the sample bacteria from their source is dependent on the time of travel of the water in the stream.

Bacteria concentrations in the streams of the area will be affected to a greater degree by the population increase associated with increased mining of coal and other energy minerals than by the mining itself. Because of the scarcity of water in the area, sewage effluent is in demand by ranchers for irrigation; sewage effluent has also been suggested as a transport medium for a coalslurry pipeline. 


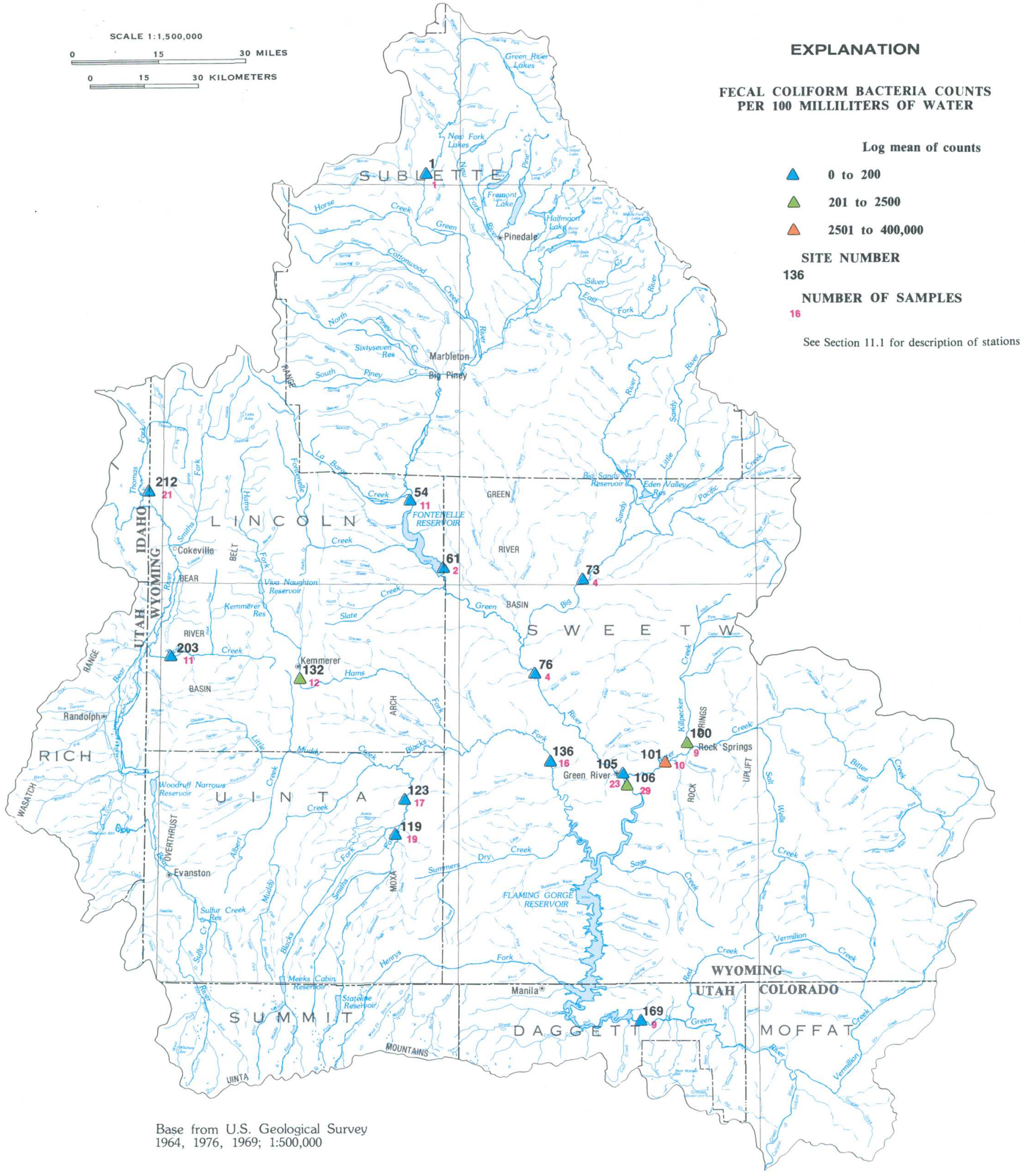

Figure 6.6-1 Samples of fecal coliform bacteria were collected at 16 stations, including several stations on the Green River. 


\title{
6.0 SURFACE-WATER QUALITY--Continued 6.7 Algae
}

\section{Phytoplankton Blooms in Plains Reservoirs and Lakes}

\author{
Many of the reservoirs and lakes in the plains are eutrophic, or nutrient rich, \\ and experience phytoplankton blooms during late summer and early fall.
}

During phytoplankton blooms, the water of many plains reservoirs and lakes turns to a pea-soup green color and has a foul odor. The occurrence of massive blue-green algae blooms in the Green River and Blacks Fork arms of Flaming Gorge Reservoir has been described by Bolke (1979), Wegner (1982), and others (see figure 6.7-1 for location). Eutrophic conditions and an abundance of blue-green algae, compared to other types of algae, were noted by the U.S. Environmental Protection Agency's National Eutrophication Survey Team in the upper portion of Flaming Gorge Reservoir (1977a), Viva Naughton Reservoir (1977e), Soda Lake (1977d), and others. The nutrient levels in the water, particularly phosphorus and nitrogen, are key factors controlling phytoplankton growth. DeLong (1983) noted that Flaming Gorge and Fontenelle Reservoirs act as traps of phosphorus in the Green River as the water passes through the reservoirs.

Blue-green algae blooms impart an objectionable taste and odor to the water and can make a drinking-water supply unpotable. When the blooms die, the dissolved oxygen in the water is depleted by the decaying cells, which can create a stress and possibly a lethal effect on fish. Some blue-green algae produce toxins during blooms; cattle deaths can result from ingesting these toxins while drinking.

Reservoirs and lakes in the mountains generally do not experience blue-green algae blooms, due largely to their low-nutrient levels. One of the reasons that a person can see to great depths in mountain lakes is because of the small numbers of phytoplankton in the water. The Environmental Protection Agency (1977b) classified Fremont Lake, a mountain lake, as oligotrophic or nutrient poor.
Samples of phytoplankton and periphyton (algae attached to the substrate) were collected from streams in the area during energy mineral-related studies by the U.S. Geological Survey (fig. 6.7-1). The largest phytoplankton concentrations in streams of the area were found in plains streams; concentrations usually were small in mountain streams. High levels of turbidity or turbulence interfere with phytoplankton growth in many of the streams. For comparative purposes, phytoplankton concentrations may easily exceed 100,000 cells per milliliter during blooms.

Phytoplankton and periphyton samples are useful as water-quality indicators in a specific stream or lake and to provide a baseline for monitoring changes (for example, see Wyoming Department of Environmental Quality, 1980, p. 9). A diverse community of diatoms generally is associated with clean waters; whereas, green and blue-green algae and euglenoids are better adapted to less pristine waters. The phytoplankton and periphyton samples from the streams of the area were often dominated by diatoms, in terms of number of cells, and the number of genera per sample. An example of this dominance is shown in figure 6.7-2. Relatively few genera of green or blue-green algae were collected in most of the samples from the area, but the green or blue-green algae sometimes dominated the cell counts. Euglenoids were uncommon, with one exception. Euglenoids dominated the cell counts of samples from Bitter Creek at site 101 because of sewage effluent.

At small or moderate concentrations algae are beneficial because algae are at the base of the aquatic food chain. Through photosynthesis, algae are the primary producers; they serve as food for animals, such as insects in streams or zooplankton in lakes, which in turn feed larger animals. Algae also make up a portion of the diet of many fish. 

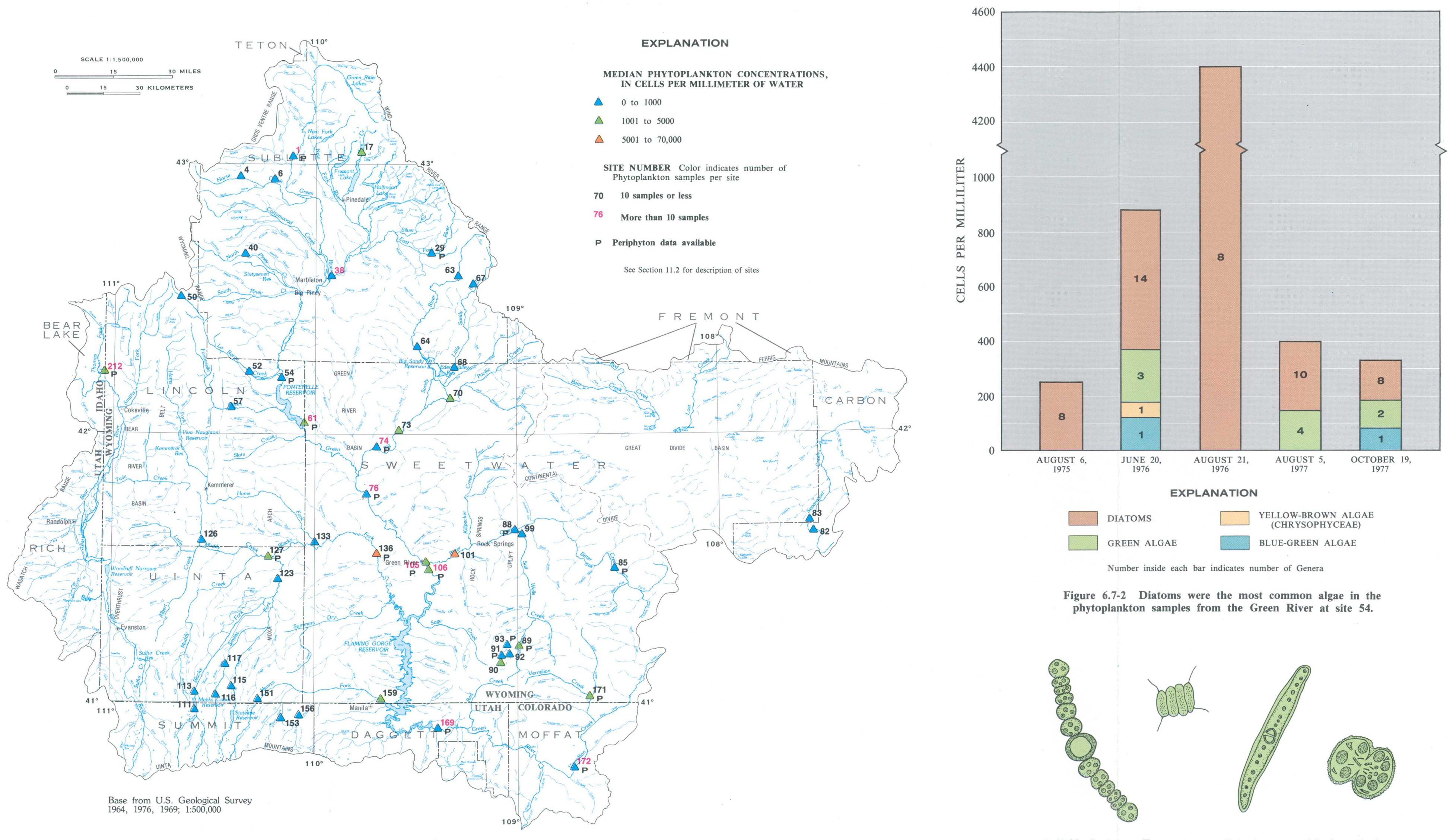

Figure 6.7-2 Diatoms were the most common algae in the
phytoplankton samples from the Green River at site 54 .
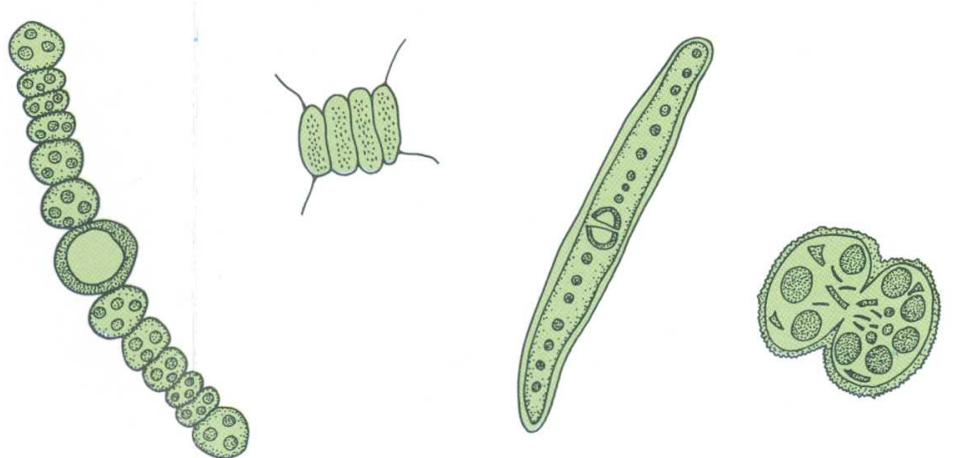

Figure 6.7-1 The largest median phytoplankton concentrations are in plains streams.

Individual algae cells are too small to be seen with the naked eye, but large concentrations of cells can make 


\subsection{SURFACE-WATER QUALITY--Continued 6.8 Invertebrates}

\section{Invertebrate Communities Indicate Good Water Quality}

\section{A variety of invertebrates adapted to clean waters were found in most streams.}

A variety of invertebrates (animals without backbones) are found in most streams of the area. Insects such as stonefly, mayfly, and dragonfly nymphs, caddisfly and midge larvae, and beetles dominate the samples. Snails, fingernail clams, mites, and worms are found in some of the samples. Large diversity, measured by an arithmetic index, and the types of invertebrates found, indicate good water quality in most of the streams that were sampled. Invertebrates are useful as water-quality indicators because they are relatively immobile and therefore reflect past water-quality conditions, whereas a water-chemistry sample or physical measurement may not be representative of past conditions.

The invertebrates were sampled in many of the plains and mountain streams in the area (fig. 6.8-1). The samples were collected from the benthos, or bottom, of riffles in each stream. Differences between taxa (taxonomic classifications) of invertebrates found in plains and mountain streams generally were due to differences in the natural environmental conditions. The water quality generally is not as good in plains streams as in mountain streams, and the invertebrate taxa reflect this. Plains streams typically have larger concentrations of dissolved solids and turbidity, higher water temperatures, and less stable substrates than mountain streams.
Examples of the different proportions of invertebrate taxa in plains and mountains streams are shown in figure 6.8-2. Generally, stonefly nymphs were common in mountain streams, but were uncommon in plains streams. Some caddisfly and mayfly taxa found in mountain streams were not found in plains streams, and vice versa. Midge larvae and beetles made up larger proportions of the invertebrate numbers in plains streams than in mountain streams. These differences are attributable to the natural environmental conditions. Bitter Creek was an exception, at site 101, several miles below a sewage outfall. The samples from this site contained relatively few invertebrates, some of which probably entered from tributaries.

Invertebrates in streams often receive attention because of their value as fish food. A principle of fly fishing is to imitate aquatic insects, especially. during the feeding frenzy induced in fish by a large hatch of mayflies or stoneflies. Caddisfly larvae, such as the one shown in figure 6.8-3 and midge larvae are also common in fish diets. Qualitative samples of the invertebrates were collected in several tributaries to the Green River by Remmick (1981). Samples of the invertebrates and zooplankton were collected during a survey of lakes in the Bridger Wilderness Area by Hudelson and others (1980). 

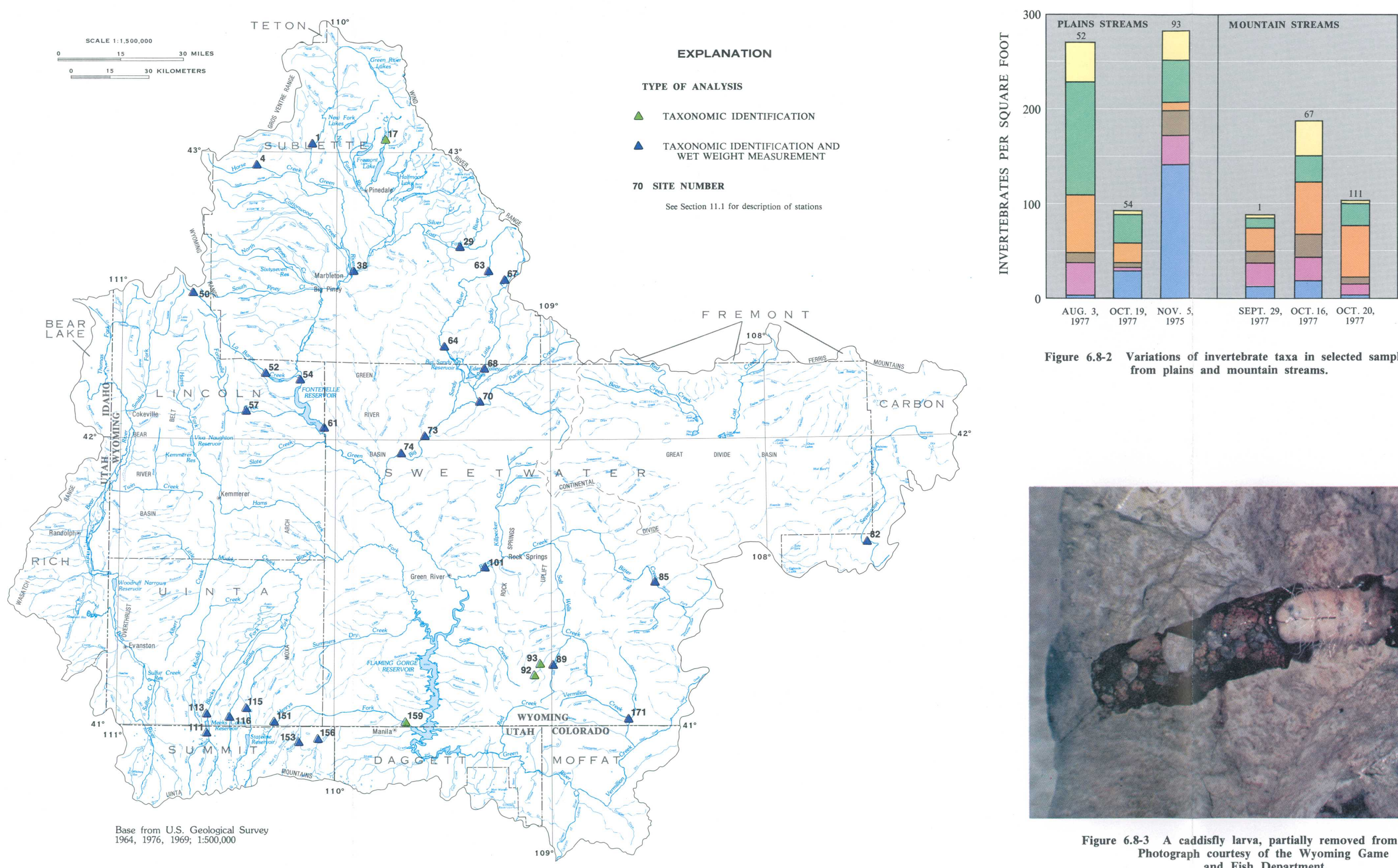

EXPLANATION

$\square$ COLEOPTERA

$\square$ DIPTERA

EPHEMEROPTERA

PLECOPTERA

$\square$ TRICHOPTERA

$\square$ OTHER

11 SITE NUMBER Figure 6.8-2 Variations of invertebrate taxa in selected samples

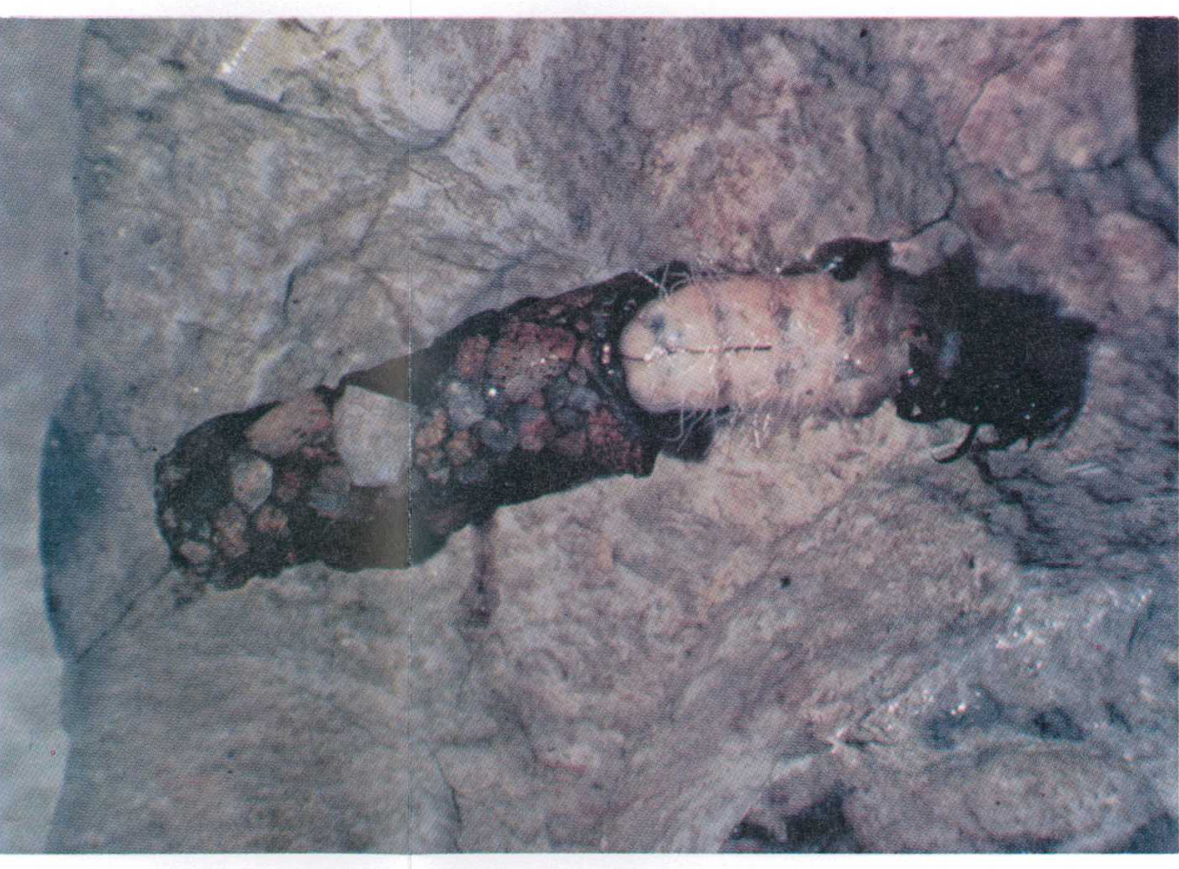

Figure 6.8-3 A caddisfly larva, partially removed from its case. Photograph courtesy of the Wyoming Game
and Fish Department. 


\title{
6.0 SURFACE-WATER QUALITY--Continued 6.9 Fish
}

\section{Green River is a Blue-Ribbon Trout Stream}

\author{
The Green River and many other rivers, lakes and reservoirs in the \\ area support trout.
}

Fishing is popular in Area 52 because of the abundance of fish and the variety of species. Cutthroat, rainbow, brown, lake, and golden trout, as well as grayling are some of the most popular cold-water game fish found in the area. More than 700,000 days were spent fishing in waters of the Wyoming portion of the Green River drainage basin in 1979 (Phillips and others, 1981, p. 21). Approximately one-half of the 700,000 days were spent on streams and rivers and one-half on standing waters.

The Green River is perhaps the most widely acclaimed trout stream in the area, and has the best rating as a fishery resource, based on the stream-classification. system shown in figure 6.9-1. The classification system was designed by the U.S. Fish and Wildlife Service in cooperation with the game and fish departments of Wyoming, Colorado, Idaho, and Utah (U.S. Fish and Wildlife Service, 1978a, 1978b, $1978 \mathrm{c}, 1979)$. The system includes the following criteria to evaluate permanent streams, their tributaries, and certain intermittent streams as fishery resources: (1) The presence of endangered or threatened species as designated by the States or Federal Government, (2) species of high interest to the State (fig. 6.9-2), and (3) habitat restoration or mitigation potential. The upper portions of the Green River, the Hams Fork and Fontenelle Creek have been inventoried by the National Park Service (1982) for possible designation as National Wild and Scenic Rivers.
Warm-water game fish are not abundant in the area. Attempts are being made to establish warm-water game fish, such as smallmouth bass and channel catfish in Flaming Gorge Reservoir, which also supports several species of trout (fig. 6.9-3). Kokanee, or landlocked salmon, also were stocked in Flaming Gorge Reservoir and have become popular with the anglers.

Game fish are absent from many streams of the plains, due to high water temperatures, poor water quality, or lack of perennial flow. Less sensitive fish, such as chubs, Bonneville redside shiners, speckled dace, fathead minnows, and suckers are found in some plains streams of the area (Baxter and Simon, 1970). Non-game fish, such as Utah chubs, interfere with the game fishery in Flaming Gorge Reservoir and other waters. The Kendall Dace, a federally listed endangered species, is found only in the Kendall Warm Springs in Sublette County.

Studies of fisheries in streams of the area include: several western tributaries to the Green River by Remick (1981), the Big Sandy River by Miller (1977), and the Bear River drainage by Miller (1977). The fisheries of lakes in the Wind River Range were surveyed by Hudelson and others (1980). 

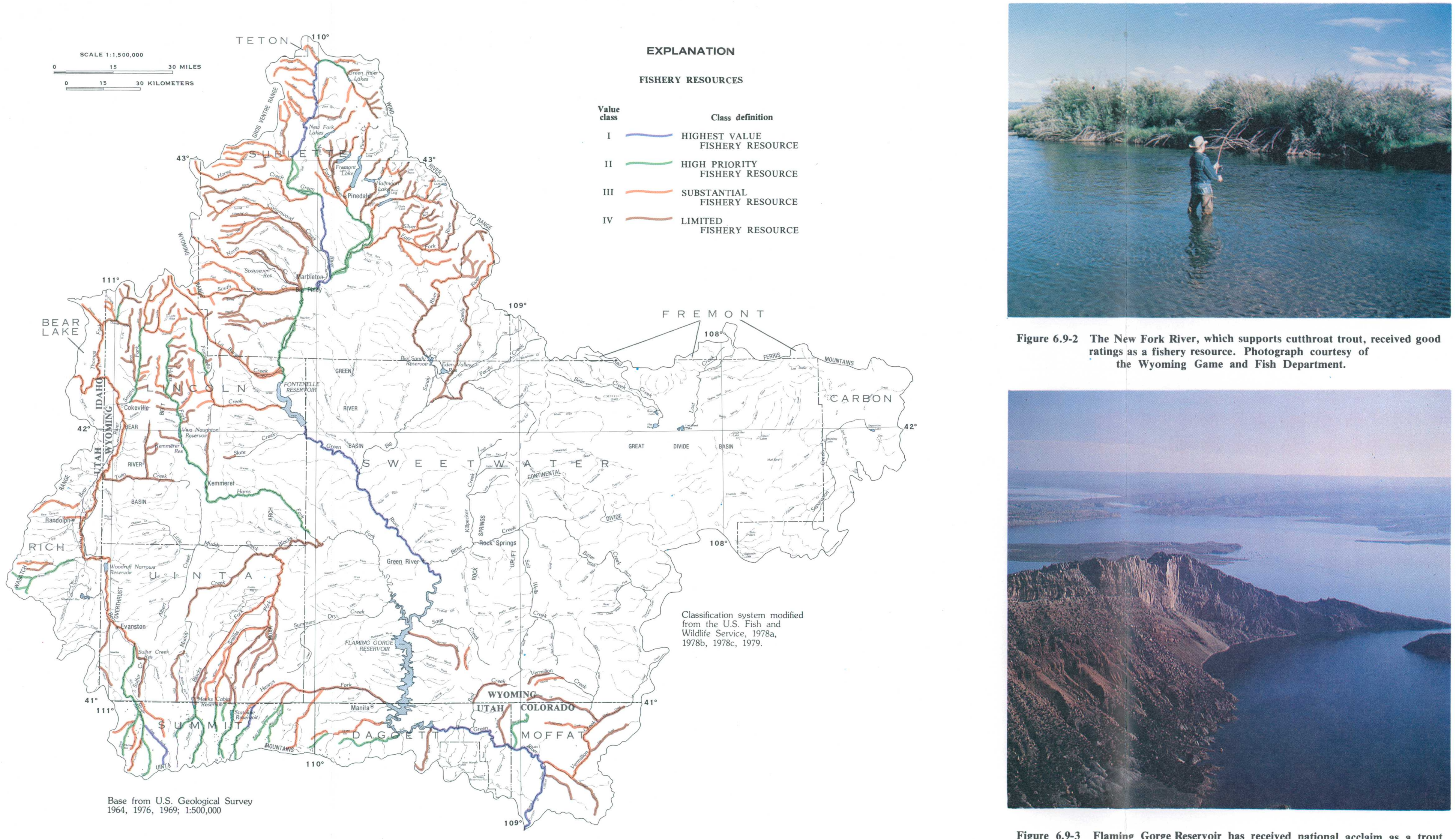

Figure 6.9-2 The New Fork River, which supports cutthroat trout, received good

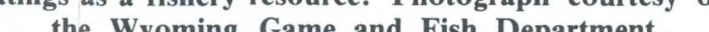

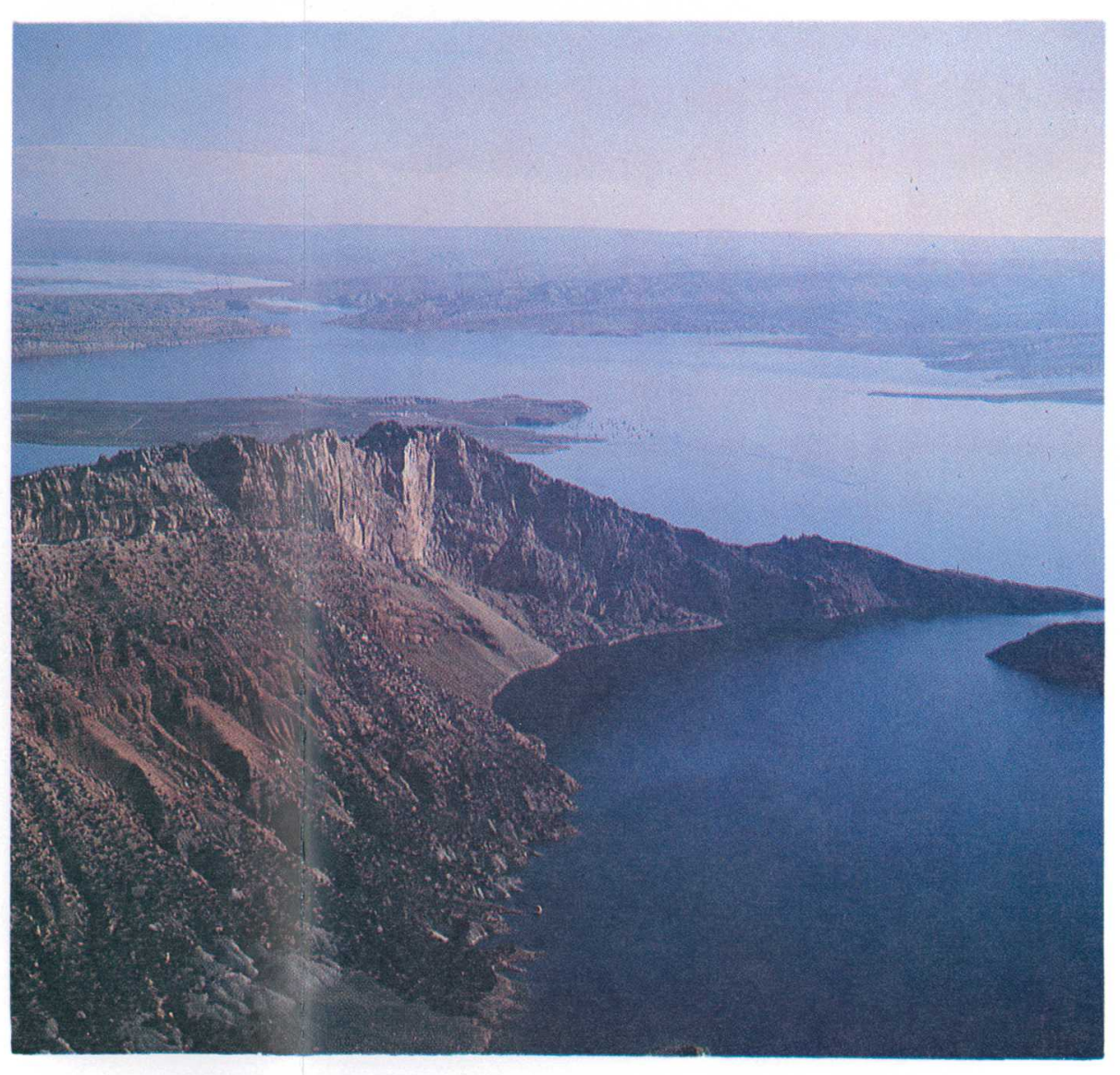

Figure 6.9-3 Flaming Gorge Reservoir has received national acclaim as a trout
fishery. Photograph courtesy of the Wyoming Game and Fish Department. 


\title{
6.0 SURFACE-WATER QUALITY--Continued \\ 6.10 Temperature
}

\section{Water Temperature is Important to Many Users}

\author{
Temperature data are available for nearly all of the surface-water stations and \\ miscellaneous sites. In Area 52 stream temperatures range from 0 degrees Celsius \\ in winter to greater than 25 degrees Celsius in summer.
}

Temperature is an important factor of water quality. It determines the physical form of water and also affects most physical processes and chemical reactions that take place in water. For example, as water temperature increases, dissolved oxygen decreases because of: (1) The decreased saturation capacity of the water, and (2) the increased oxygen consumption of aquatic life. In contrast, the solubility of various substances in water increases with temperature. Because of its effect on water quality, stream temperature affects water use and aquatic life.

Water temperature is important to many water users. It is important to the sportsman, as it is a vital factor affecting fish life. It is important to agricultural users, as temperature of irrigation water can affect crop production. Industrial water users commonly use water for cooling purposes, and need to consider stream temperature in plant design and operation.

Stream temperature is significantly affected by the surrounding climatic and physical conditions. Climatic factors that affect water temperature include solar radiation, wind, air temperature, and vapor pressure. Important physical factors include shading, ground-water inflows, aspect of the stream, and stream width, depth, and velocity. Waste discharges and reservoirs also may have significant effects on the temperature of water in streams.

Observations of water temperature are made at surface-water stations whenever discharge measurements are made (fig. 6.10-1). These measurements are made monthly, and a summary of the data has been compiled by Lowham and others (1975). Periodic observations of water temperature made at a streamflow station on the Green River (site 105) are shown in figure 6.10-2. Water temperature is also measured whenever water-quality samples are obtained, and automatic monitors sometimes are installed that measure temperature continuously. Daily mean temperatures recorded by an automatic monitor at a waterquality station on Separation Creek (site 83) are shown in figure 6.10-3. Some temperature data are available for nearly all of the regular surface-water stations and miscellaneous sites operated by the U.S. Geological Survey (See Section 11.0 for complete listing of these sites). Sites where sufficient temperature observations are available to define average seasonal variations are shown on the map in figure $6.10-1$.

Stream temperatures in Area 52 may vary annually from 0 degrees Celsius during winter periods to greater than 25 degrees Celsius in late summer. Seasonal streamtemperature patterns exhibit a cyclical pattern through the year, as shown in figures $6.10-2$ and $6.10-3$. This cyclical pattern can be mathematically described with a curve known as a harmonic function. Such curves were fitted by Lowham (1978) to temperature observations made at 43 long-term stations. Terms of the function were then related to regional characteristics such as site elevation so that stream temperature can be estimated at unmeasured sites. As an example, the estimating method was used to construct a curve representing mean daily temperatures to be expected at site 83 (fig. 6.10-3). This curve compares quite closely with the actual temperatures recorded at the station during the 1976 water year. Additional information for use of the estimating method is available in the report by Lowham.

In addition to seasonal fluctuations, temperatures also may vary within each day. Variation is greatest during late summer and least during winter. The temperature during a day may vary as much as 20 degrees Celsius in small plains streams, but generally varies less than 5 degrees Celsius in large perennial streams. 

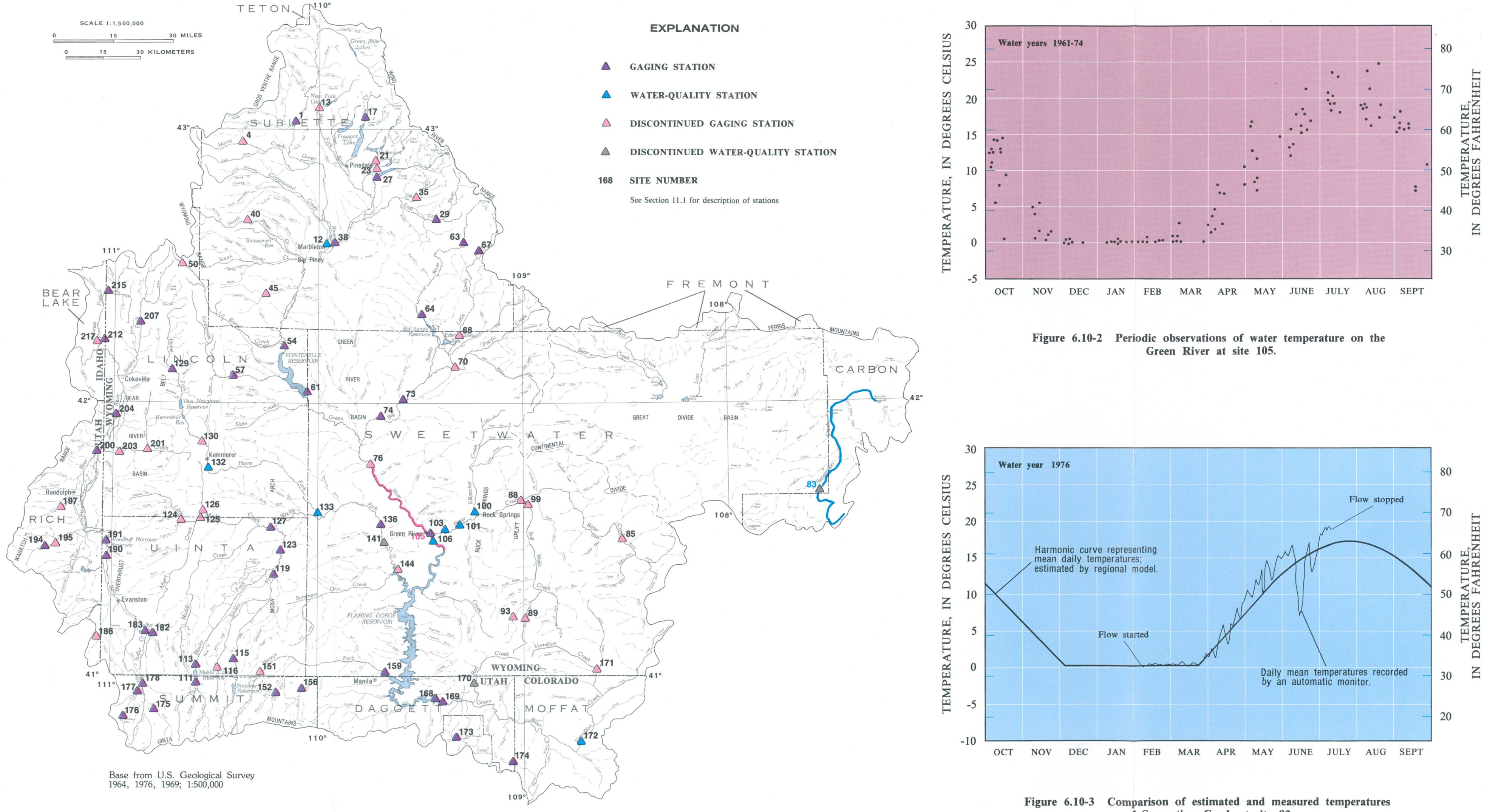

Figure 6.10-2 Periodic observations of water temperature on the River at site 105

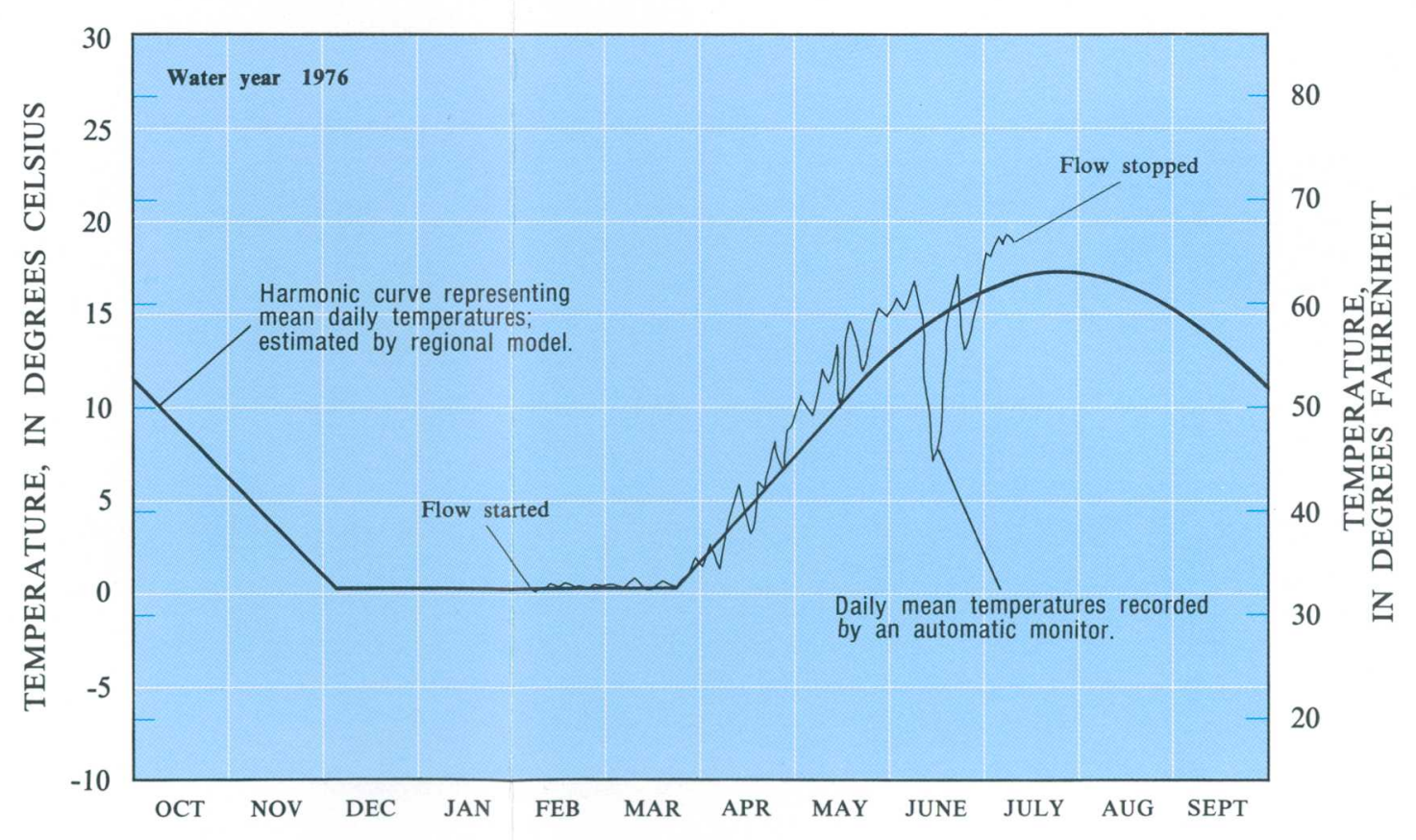

Figure 6.10-3 Comparison of estimated and measured temperatures of Separation Creek at site 83 . 


\title{
7.0 GROUND-WATER DATA AVAILABLE
}

\author{
Data on Almost 1,800 Sites Available
}

\author{
U.S. Geological Survey files contain data on more than 1,500 wells, almost 260 \\ springs, and water levels in over 200 observation wells in Area 52. \\ Reconnaissance studies are available for most of the area.
}

The computer files of the U.S. Geological Survey GWSI (Ground-Water Site Inventory) files contain records of almost 1,800 ground-water sites in Area 52. These sites include more than 1,500 wells, almost 260 springs, and one tunnel (a well drilled into an abandoned coal-mine tunnel). The distribution of the sites is shown on figure 7.0-1. The files include repeated water-level measurements on more than 200 observation wells. Data from continuous water-level recorders on three wells are in the daily-values file.

Some of the observation wells are or have been part of the statewide observation-well networks. Measurements have been suspended on most of them; about 25 wells remain. Some have been used for restricted projects and measurements were droppped when the projects ended. For instance more than 50 shallow observation wells were installed by the Geological Survey for a study of the effect of irrigation on ground water along the East Fork of the Green River (O'Connell, 1969). Water levels were measured for two years. The U.S. Bureau of Reclamation installed more than 100 observation wells near the Eden-Farson irrigation project to study ground-water flow and discharge to the Big Sandy River-a contributor of salinity to the Colorado River. These wells have been measured by Bureau of Reclamation personnel since the well installation beginning in 1976 .

Additional data are available from several state agencies for ground-water sites not yet added to the Geological Survey files. The Wyoming State Engineer and his counterparts in Idaho and Utah, maintain files of ground-water sites for which water rights have been granted. The Wyoming Department of Environmental Quality receives and files reports of water levels measured by mines and other industrial plants in compliance with monitoring requirements.

Sites shown on the map (fig. 7.0-1) generally are densely concentrated where rural population is concentrated. Sites are too close together in many places to identify each site on the map. The principal concentrations are on the Lyman-Mountain View irrigation project, the Eden-Farson irrigation project, and the mountain front near Pinedale, Wyo. Many suburban wells are near Rock Springs, Wyo. Many sites also are concentrated along major stream valleys and highways.
Several areal ground-water reconnaissance studies have been conducted on parts of Area 52. Berry (1960) wrote Water Supply Paper 1458 about the geology and ground-water resources of the Rawlins area. Robinove and Berry (1963) wrote about ground water in the Bear River Valley. Robinove and Cummings (1963) described the ground water and geology of the Lyman-Mountain View area of Uinta County. Hydrologic Investigations Atlases were prepared by Welder and McGreevy (1966) for the Great Divide and Washakie Basins, by Welder (1968) for the Green River Basin, and by Lines and Glass (1975) for the thrust belt of western Wyoming. Studies now in preparation (1983) include a study of the hydrology of an experimental underground oil-shale retort near Rock Springs and a regional aquifer system analysis (commonly called a RASA) of the upper Colorado River Basin (including the Green River and Great Divide Basins). The published reports are for sale by the U.S. Geological Survey. Further information on current studies is available from the U.S. Geological Survey in Cheyenne, Wyo.

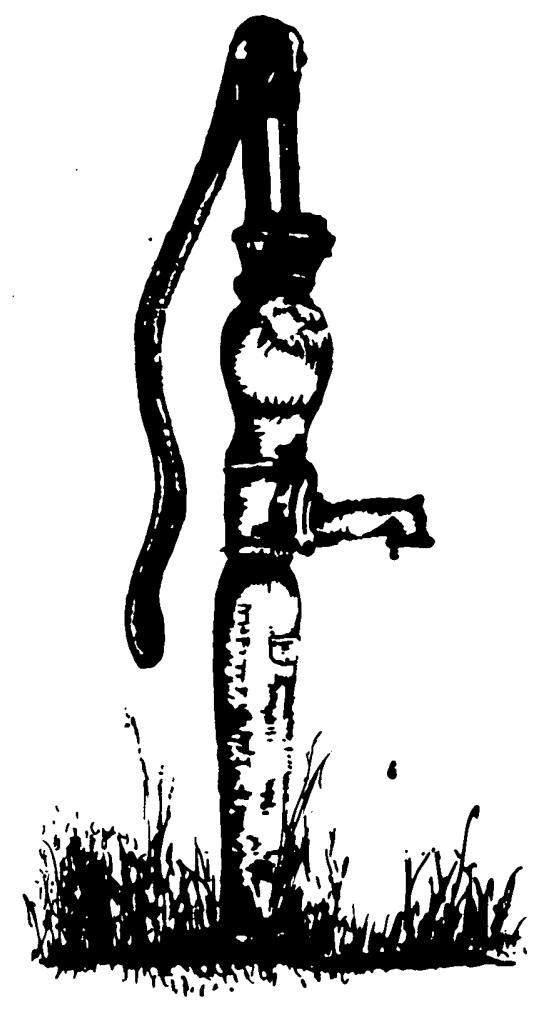



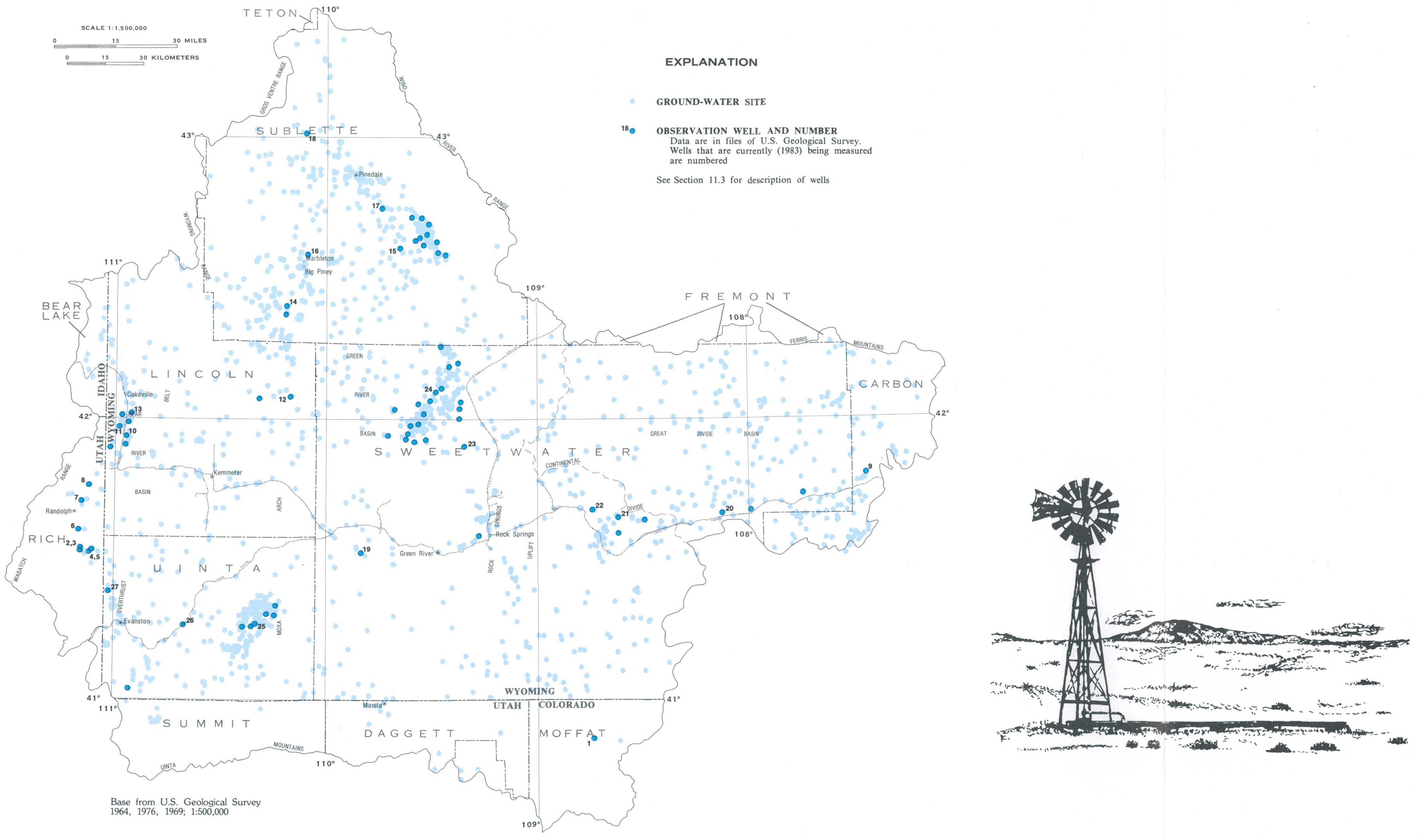


\title{
8.0 GROUND-WATER QUANTITY \\ 8.1 Movement
}

\section{Wasatch Rocks Form the Most Extensive and Therefore Important Water-Bearing Formation in the Area}

\author{
Ground water flows through the rock as impelled by gravity from recharge \\ areas to discharge areas. Perennial streams in Area 52 receive their \\ low flows from ground-water discharge.
}

Ground water moves through the rocks under both confined and unconfined conditions in Area 52. Recharge flows from places where water from precipitation or applied irrigation water enters the ground to places where it is discharged, typically streams, springs, wells, or evaporation sites. The direction of movement can be inferred from water-table or potentiometric-surface maps such as that in figure 8.1-1. Water flow is perpendicular to the contours. This map is of the potentiometric surface of Wasatch rocks that form the most extensive and therefore important water- bearing formation in Area 52. The inferred flow generally is from recharge areas along the mountains to discharge to the Green River and its tributaries or to lakes in the Great Divide Basin where the water evaporates.

Ground water typically flows very slowly through the rocks because its flow is impeded by the rock material. It flows through small openings between grains, cracks, and solution cavities. The rate at which it flows is governed by the abundance, degree of interconnection, and size of these openings (which determine permeability), by the cross-sectional area through which it flows, and by the gradient (altitude or head difference).

Where the rock contains large openings, such as caves in limestone, water can move rapidly as it does at the spring shown in the photograph, but in more typical circumstances it moves slowly through the pores in sandstone. The volume of water flowing through even small pores in a thick, broad section of rock may be very great, however.

Discharge of ground water to streams is an important factor in determining if the stream is perennial. Most of the high flows in streams are from the melting of snow or ice or from rainstorms, but in Area 52, periods of weeks or months may pass when snow or ice does not melt (because of cold weather) and no rain falls. If the stream continues to flow through these periods it almost certainly is sustained by ground water.

Iorns and others $(1965$, p. 259$)$ estimated the percentage of ground-water contribution to streams in the Green River drainage basin part of the upper Colorado River Basin on the basis of flow-duration curve characteristics (Iorns and others, 1965, p. 48). Their estimates for 12 sites appear on figure 8.1-1. Streams flowing through valleys of thick and extensive alluvium generally receive most of their flow from ground water. Streams flowing through narrow bedrock canyons receive the least flow from ground water. Large bedrock springs can alter this general relationship, however.
Thick and extensive alluvium along streams is wellsituated to receive recharge from the streams during high water and floods or from irrigation by surface water applied to fields on the alluvium. The recharged water may flow slowly through the ground back to the stream from which it came. The slow return of this water may sustain the flow of the stream at a relatively high level well into dry periods.

Upland terrace deposits also are recharged by irrigation water near Farson and Lyman, Wyo. Some of the water in the terrace deposits returns to the stream via springs in draws or drainage ditches, but some recharges the underlying bedrock. In some of the draws, discharge is less than the rate of evaporation and is represented by crusts of various salts locally called "alkali".-the residue of the evaporated water. Of the water that recharges bedrock under the irrigated terraces, some flows through the rock to seeps and springs that discharge to the streams. As it flows through the rock it may dissolve minerals in the rock and carry them into the stream. This process is thought by some to cause the substantial increase in the dissolved-solids concentration of water in the Big Sandy River downstream from the irrigated land near Farson, Wyo. (U.S. Department of Agriculture, 1980, p. S-1).

Preliminary investigation indicates that, in the Bear River Valley, the alluvium is recharged by flow from small tributaries debouching from narrow canyons onto the valley floor. Much of the flow of these tributaries is lost to alluvial fans at the canyon mouths. From the fans, the water flows into the river alluvium and is discharged into the river or by phreatophytes (plants with a deep root system capable of reaching ground water) (Glover, oral commun., 1983).

Ground-water flow systems near streams or in irrigation projects are too local to be shown on maps of the scale of figure 8.1-1. The general flow pattern of unconfined water in connection with a stream is shown in figure 8.1-2; that of confined water in bedrock aquifers is shown in figure 8.1-3. Confined water, also called artesian, is ground water in a water-bearing bed overlain and underlain by relatively impermeable beds preventing vertical flow. The water will rise above the top of the water- bearing bed in a tightly cased well. Unconfined, or water-table ground water is in contact with the atmosphere, and the water level in a well is the same as that in the formation. 

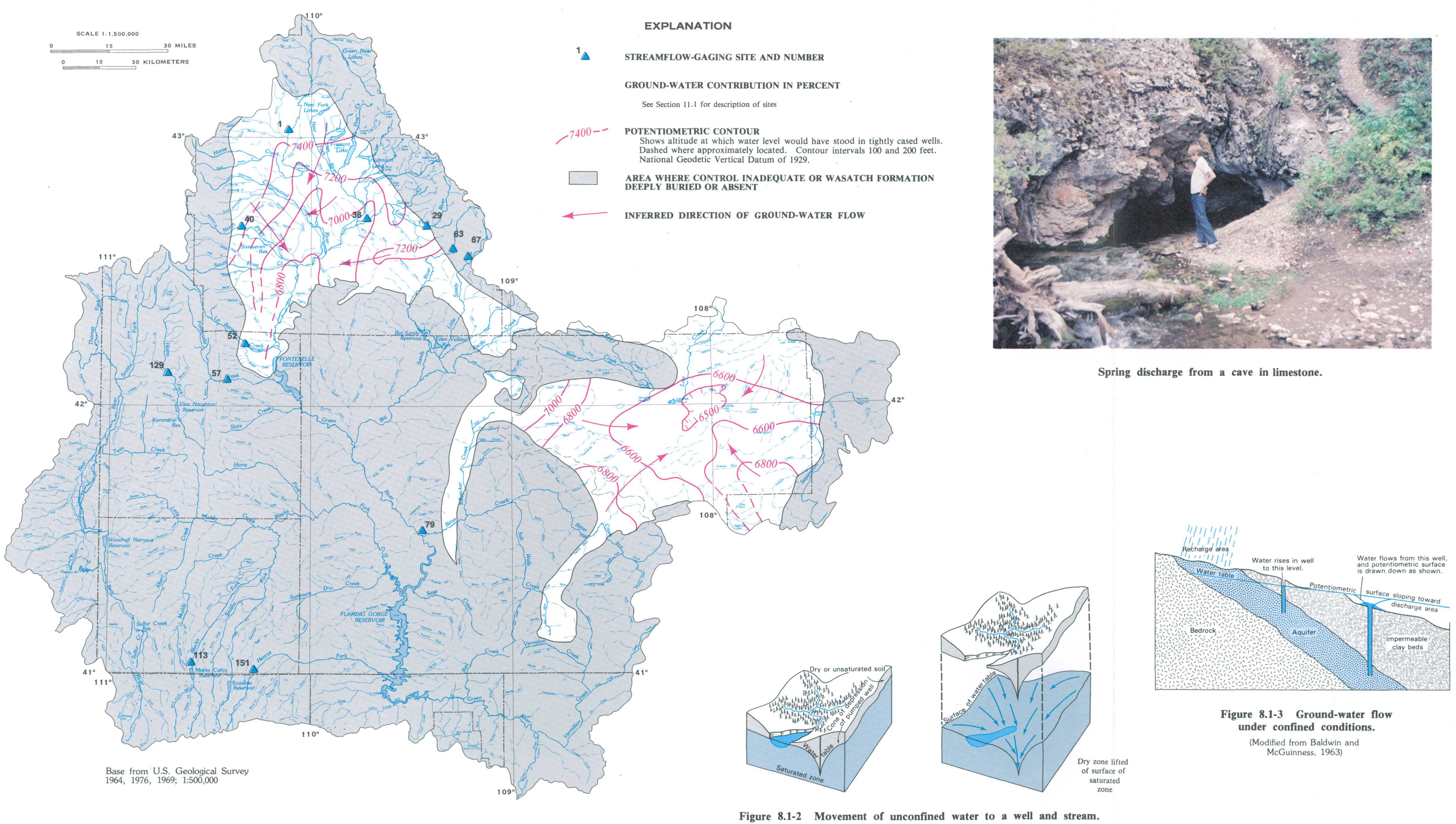

Figure 8.1-1 Potentiometric surface of the Wasatch Formation

Figure 8.1-2 Movement of unconfined water to a well and stream.

and correlative Battle Spring Formation. 


\title{
8.0 GROUND-WATER QUANTITY--Continued \\ 8.2 Aquifer Potential
}

\section{Yields of More than 5,000 Gallons per Minute Recorded}

\author{
Some wells and springs in Area 52 yield more than 5,000 gallons per minute, but \\ most yield about 20 gallons per minute. Most wells tap sandstone aquifers at \\ depths less than 500 feet.
}

Ground water is present below a certain depth almost anywhere, but it is readily obtainable in useable quantities only wherè saturated rocks are porous and permeable enough to store and transmit the water at adequate rates. These characteristics of porosity and permeability are properties of the rocks and therefore of the formations into which the rocks are grouped.

Ground-water sites in Area 52 obtain water from at least 21 different types of rocks, but sandstone, sand and gravel, sand, gravel, shaley sandstone, and shale are the principal source rocks in about 90 percent of the sites. Table 8.2-1 lists yields recorded for each of these source rocks in Area 52 for both pumped wells and flowing wells or springs where applicable. Limestone is the source rock for very few sites, but the largest yield from any site in Area 52 is over $5,000 \mathrm{gal} / \mathrm{min}$ (gallons per minute) from a spring issuing from a cave in limestone.

Limestone can be dissolved, thus forming caves. Water moves readily through the caves, but the caves are sparsely distributed. The major limestone beds are at great depths in most of the area so few wells penetrate them.

The Tertiary Wasatch Formation, which is the principal aquifer in the area, yields water mainly from sandstone. Pumped discharge from the formation ranges from 0.5 to $688 \mathrm{gal} / \mathrm{min}$ with a median discharge of $22.2 \mathrm{gal} / \mathrm{min}$. Flowing wells yield from 0.2 to $550 \mathrm{gal} / \mathrm{min}$ with a median flow of $15 \mathrm{gal} / \mathrm{min}$.

Wells in the most recently deposited rocks in the area, alluvium, terrace deposits, dune sand, and glacial drift have a maximum yield of $1,350 \mathrm{gal} / \mathrm{min}$, a mininum of 2 $\mathrm{gal} / \mathrm{min}$, and a median of $25 \mathrm{gal} / \mathrm{min}$. Yields from alluvium are especially high in the Bear River Valley where recurrent faulting has dropped the valley in relation to surrounding uplands and permitted accumulation of several hundred feet of sediment. Wells producing hundreds of gallons of water per minute are used for sprinkler irrigation such as that shown in figure 8.2-1.

Other important water-bearing formations in Area 52 include the following:
1. The Mesaverde Group with pumped wells yielding up to $250 \mathrm{gal} / \mathrm{min}$ with a median of 11 and flowing wells yielding up to $500 \mathrm{gal} / \mathrm{min}$ with a median of $7 \mathrm{gal} / \mathrm{min}$.

2. The Fort Union Formation with pumped wells yielding up to $300 \mathrm{gal} / \mathrm{min}$ with a median yield of 16.5 $\mathrm{gal} / \mathrm{min}$.

3. The Green River Formation with flowing wells yielding up to $900 \mathrm{gal} / \mathrm{min}$ with a median flow of 10 $\mathrm{gal} / \mathrm{min}$.

4. The Bridger Formation with pumped wells yielding up to $50 \mathrm{gal} / \mathrm{min}$ with a median yield of $5.5 \mathrm{gal} / \mathrm{min}$.

The yields cited are largely those reported by drillers or owners. Most of the wells were installed to provide water for livestock or domestic use. Because these uses do not demand a great deal of water, the wells may not have been pumped as hard as they could have been. The reported yield may have been the capacity of the pump--not the well. Higher yields may be obtainable. The yields are those in the GWSI (Ground Water Site Inventory) computer data files. For many sites the producing formation is entered but not the rock type. This leads to some inconsistencies in that some formations that are predominantly of one rock type may have yields entered that are outside the extremes for the rock type in table 8.2-1.

The unusually large yields from shale and from shaley sandstone (ordinarily rock types with small yields) may stem, in places, from drillers finding water in sandstone above a shale bed. The apparent yield would reach a maximum when the shale is first penetrated and create the impression that the water came from the shale. Some shale beds also contain considerable silica making the shale brittle and subject to fracturing: The fractures may readily transmit water to wells.

The depth to which wells are drilled for ordinary uses rarely exceeds 500 feet, but to obtain flowing water, deeper wells may be drilled. Few exceed 2,000 feet in depth; most that do are converted from oil-test holes. 
Table 8.2-1 Yields of wells in common source rocks, in gallons per minute.

\begin{tabular}{|c|c|c|c|c|}
\hline Source rock & $\begin{array}{l}\text { Number } \\
\text { of sites }\end{array}$ & $\underset{\text { yield }}{\text { Minimum }}$ & $\begin{array}{c}\text { Maximum } \\
\text { yield }\end{array}$ & $\begin{array}{c}\text { Median } \\
\text { yield }\end{array}$ \\
\hline \multicolumn{5}{|l|}{ Sandstone } \\
\hline Pumped & 277 & 0.4 & 688 & 25 \\
\hline Flowing & 60 & .2 & 2,700 & 20 \\
\hline \multicolumn{5}{|c|}{ Sandstone and gravel } \\
\hline Pumped & 12 & 2 & 1,000 & 22.5 \\
\hline \multicolumn{5}{|l|}{ Sand } \\
\hline Pumped & 30 & 1 & 302 & 25 \\
\hline \multicolumn{5}{|l|}{ Gravel } \\
\hline Pumped & 6 & 4.5 & 60 & 20 \\
\hline \multicolumn{5}{|c|}{ Shaley sandstone } \\
\hline Pumped & 21 & .5 & 152 & 25 \\
\hline Flowing & 5 & 15 & 500 & 17.5 \\
\hline \multicolumn{5}{|l|}{ Shale } \\
\hline Pumped & 28 & 1.5 & 81 & 15 \\
\hline
\end{tabular}

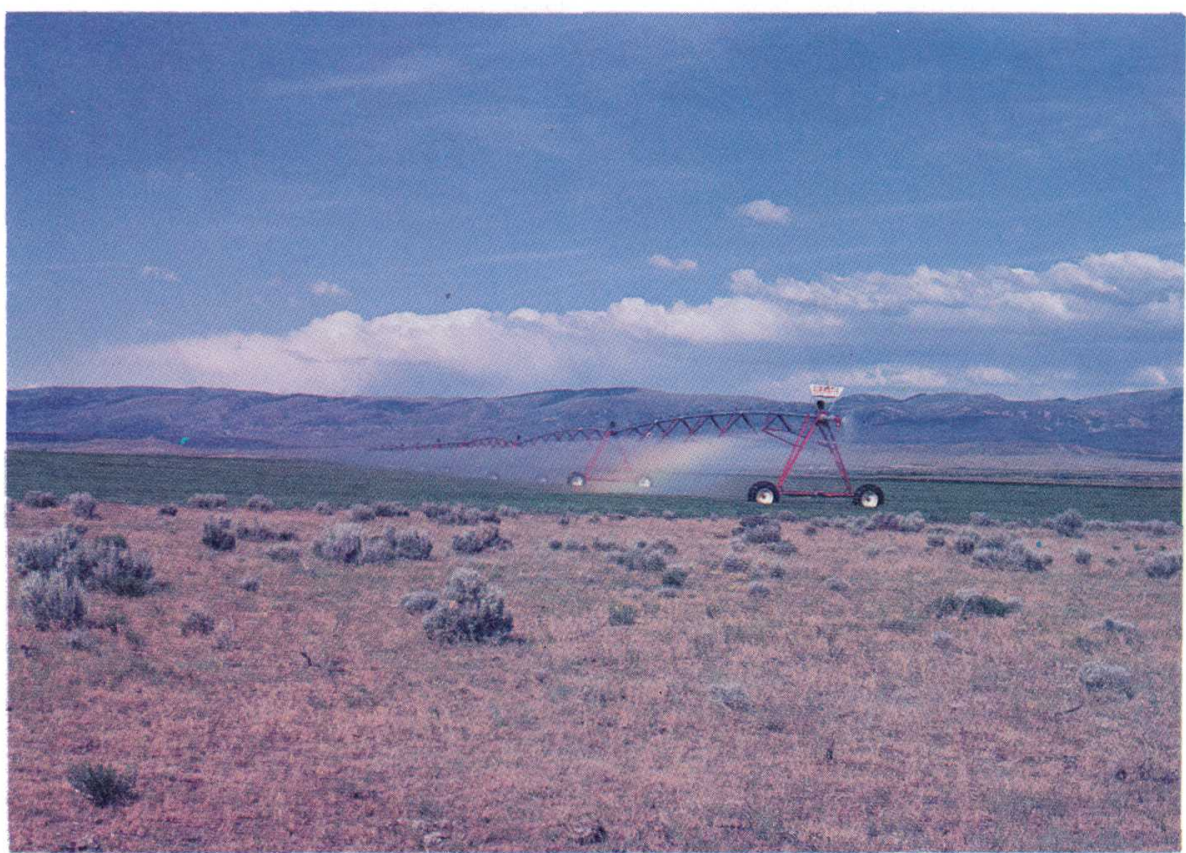

Figure 8.2-1 Sprinkler irrigation using water from alluvium in the Bear River Valley. 


\title{
9.0 GROUND-WATER QUALITY \\ 9.1 Dissolved Solids
}

\section{Ground Water of Good Quality Not Available Everywhere in Area}

\author{
Generally wells which yield water having low dissolved-solids concentrations \\ are in or near the mountainous recharge areas. Only 40 percent of the wells \\ and springs in the area have dissolved-solids concentrations that meet the \\ National drinking-water standard, although most are satisfactory for livestock.
}

\begin{abstract}
Although many wells and springs yield water (fig. 9.1-1) with dissolved-solids concentrations less than 500 $\mathrm{mg} / \mathrm{L}$ (milligrams per liter), Most ground-water samples with low dissolved-solids concentrations were collected from wells or springs in or near the mountains. As a general rule, shallow wells near the recharge areas are lower in dissolved-solids concentrations than wells remote from the recharge area. This reflects the fact that the rain, snowmelt, or stream water recharging an aquifer in the mountains is low in dissolved-solids concentrations but becomes enriched in dissolved solids as it moves down gradient toward the center of the basin. However, local recharge-discharge systems likely predominate for shallow aquifers. The 521 ground-water samples summarized in figure 9.1-2 were collected from 67 different geologic units. The largest number of samples (101) were collected from the Wasatch Formation. The dissolved-solids concentrations from this formation ranged from $149 \mathrm{mg} / \mathrm{L}$ to $9,710 \mathrm{mg} / \mathrm{L}$. The average concentration was $1,030 \mathrm{mg} / \mathrm{L}$.
\end{abstract}

The histogram for dissolved-solids concentrations sampled from wells and springs in the area (fig. 9.1-2) shows that only 40 percent of the ground-water samples had dissolved-solids within the $500 \mathrm{mg} / \mathrm{L}$ maximum concentration recommended by the National Secondary Drinking Water Regulation (U.S. Environmental Pro- tection Agency, 1979, p. 42198). However, the secondary regulations are not mandatory and the $500 \mathrm{mg} / \mathrm{L} \max -$ imum recommended often is exceeded in the arid West because water that meets this criterion often is unavailable. High dissolved-solids concentrations in domestic supplies may cause poor taste, problems due to hardness, laxative effect, high sodium concentrations, corrosion and scaling.

Watering of livestock is a common use of ground water in the area, and most of the wells, from which samples were collected, are for livestock use (fig. 9.1-3). The dissolved-solids criterion is much less stringent for this use than for a domestic supply. Water with dissolvedsolids concentrations of less than $5,000 \mathrm{mg} / \mathrm{L}$ generally is suitable for livestock. Ninty-two percent of the samples are within this range. Table 9.1-1 comments on the suitability of water for livestock and poultry for various ranges of dissolved-solids concentrations.

Ground water is used for irrigation in the Bear River Valley where well yields are high and the dissolvedsolids concentrations are low. Salinity classification of water for irrigation in an arid or semiarid area is shown in table 9.1-2. 
EXPLANATION

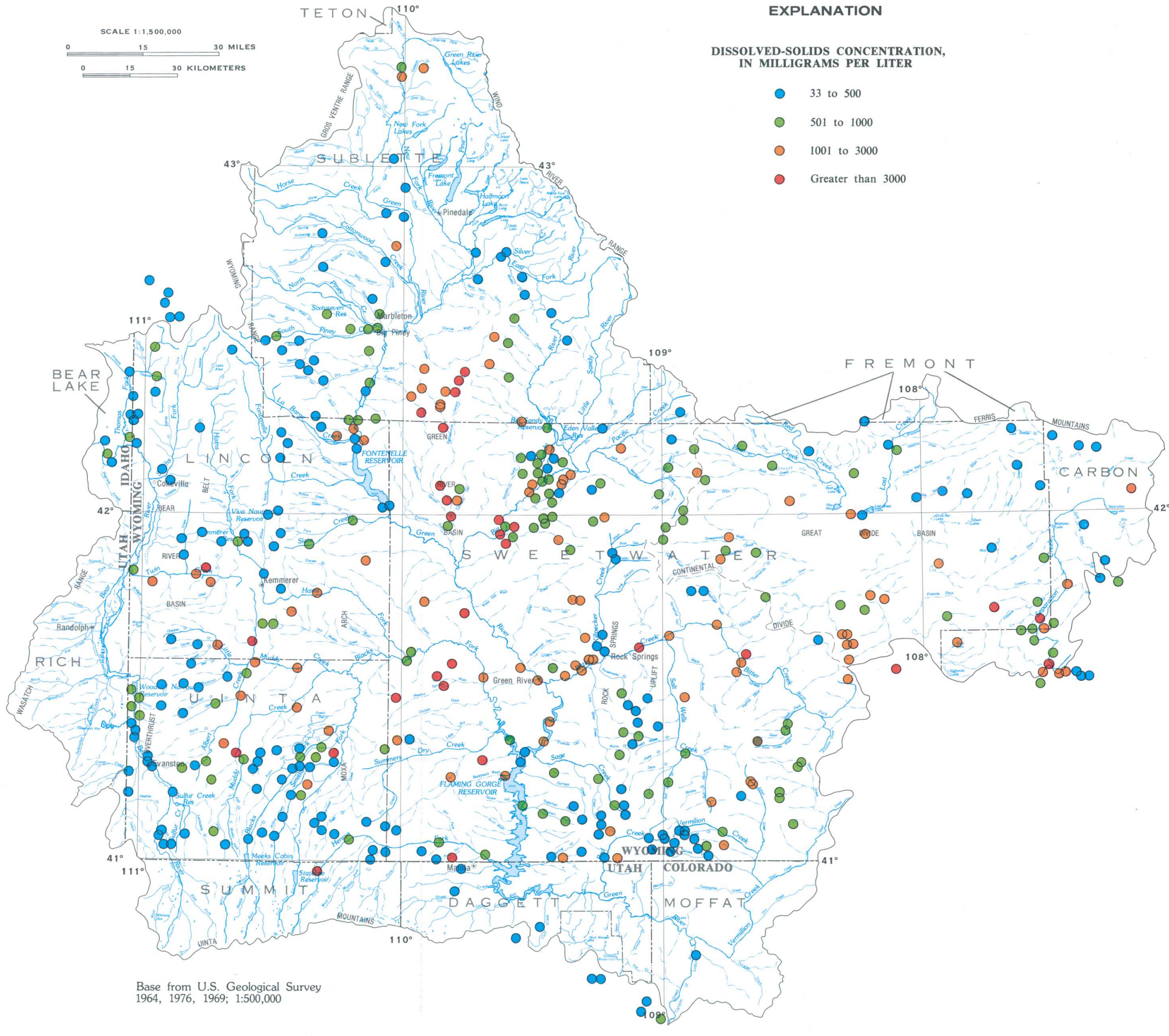

Figure 9.1-1 Dissolved-solids concentrations of water from wells and spring.

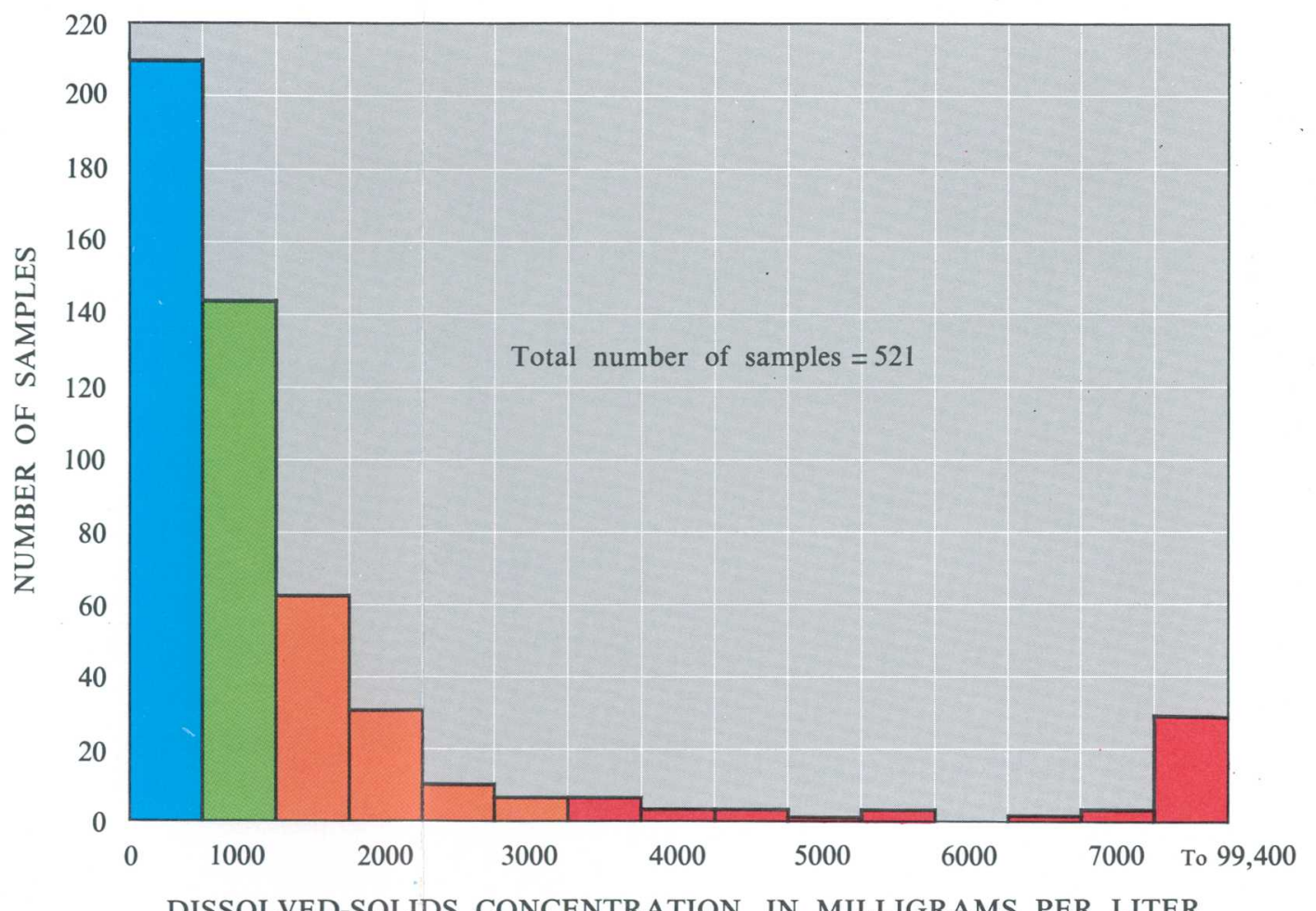

DISSOLVED-SOLIDS CONCENTRATION, IN MILLIGRAMS PER LITER

Figure 9.1-2 Histogram of dissolved-solids concentrations of water sampled from wells and springs.

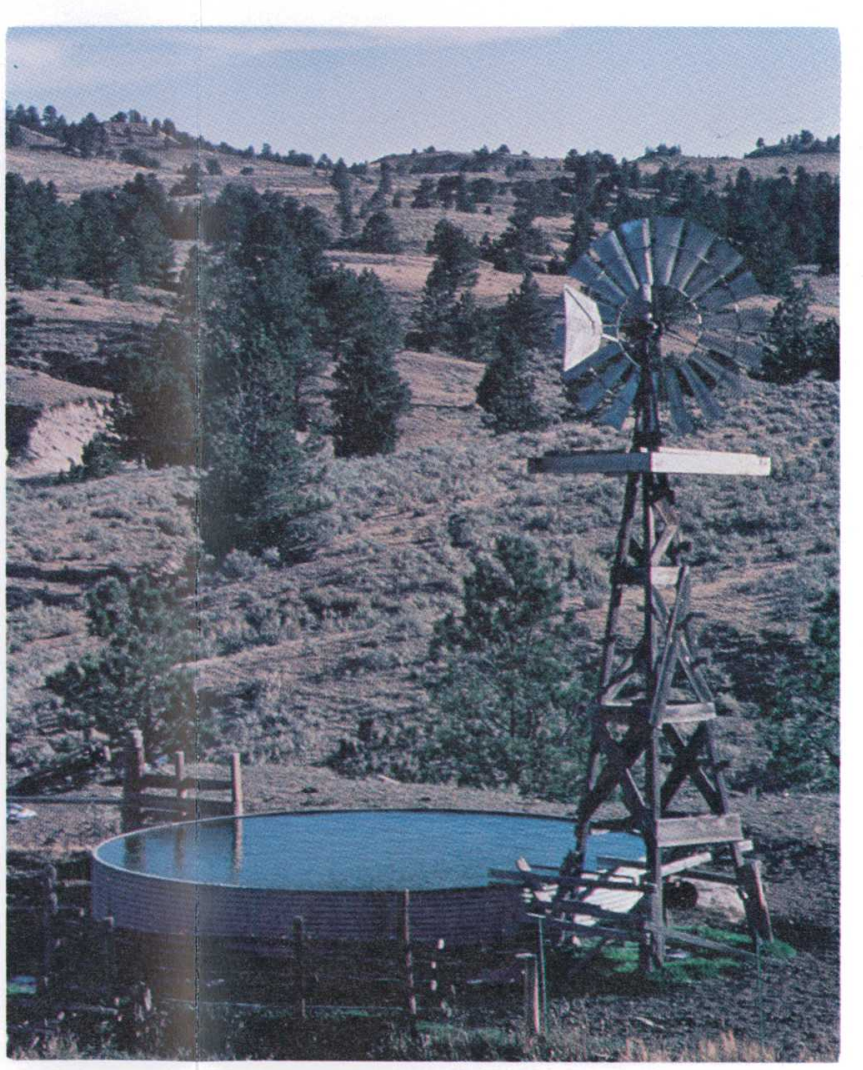

Figure 9.1-3 Wells and springs are an important source
of water to livestock and wildlife. Photograph courtesy to livestock and wildlife. Photograph
of the Wyoming Travel Commission. 


\title{
9.0 GROUND-WATER QUALITY--Continued 9.2 Iron and Manganese
}

\section{Iron and Manganese are Minor Problems}

\author{
About 13 percent of ground-water samples analyzed for iron and about 16 percent \\ of ground-water samples analyzed for manganese exceeded the National Secondary \\ Drinking-Water Standards.
}

The concentrations of dissolved iron and manganese in water samples collected from wells and springs in the area are summarized by figures $9.2-1$ and $9.2-2$. The National Secondary Drinking Water Regulations recommend a maximum iron concentration of $300 \mu \mathrm{g} / \mathrm{L}$ (micrograms per liter) and a maximum manganese concentration of $50 \mu \mathrm{g} / \mathrm{L}$ (U.S. Environmental Protection Agency, 1979, p. 42,198). About 13 percent of the iron and 16 percent of the manganese samples exceeded the standards. For domestic use, iron and manganese in concentrations above the drinking-water standards are objectionable because they impart an undesirable taste to water and cause staining of laundry and plumbing fixtures.

Under reducing conditions, iron and manganese are relatively soluble as ferrous and manganous ions. When wells yielding water with high concentrations of iron and manganese are used for domestic supplies, the soluble ferrous and manganous ions are oxidized upon exposure to the atmosphere to insoluble ferric and manganic oxides, discoloring plumbing fixtures and laundry.

The ability to taste iron in water varies widely among individuals. The National Academy of Sciences and National Academy of Engineering, (1973, p. 69) reported that 5 percent of a test panel could taste iron at a concentration of $40 \mu \mathrm{g} / \mathrm{L}$, and 20 percent at a concentration of $300 \mu \mathrm{g} / \mathrm{L}$. However, surprisingly, 5 percent of the panel were unable to detect the iron at a concentration of $256,000 \mu \mathrm{g} / \mathrm{L}$ !
Iron and manganese are not considered as problems in water used for livestock, and therefore the National Academy of Sciences and National Academy of Engineering (1973) did not feel it necessary to recommend upper limits. Both elements are recognized as essential trace elements even though both are toxic at high levels when administered as salts in feed.

Soluble iron in irrigation water is not likely to be toxic to plants. However, soluble iron salts may lower the soil $\mathrm{pH}$ and may cause the fixation of phosphorus and molybdenum. For these two reasons, the National Academy of Sciences and National Academy of Engineering (1973, p. 343 ) recommends a maximum iron concentration of 20,000 $\mu \mathrm{g} / \mathrm{L}$ over a 20 -year period for use on alkaline or neutral soils. Such high levels of dissolved iron are not common in this area.

Manganese in acid soils is toxic to a variety of crops. However, soils of the area are neutral to alkaline. For such soils the National Academy of Sciences and National Academy of Engineering (1973, p. 344) recommends a maximum manganese concentrations in irrigation water of $10,000 \mu \mathrm{g} / \mathrm{L}$ for up to 20 -year period. Higher concentrations can be used with alkaline soil and crops with high manganese tolerance levels. Manganese in irrigation water is not a documented problem in this area. 


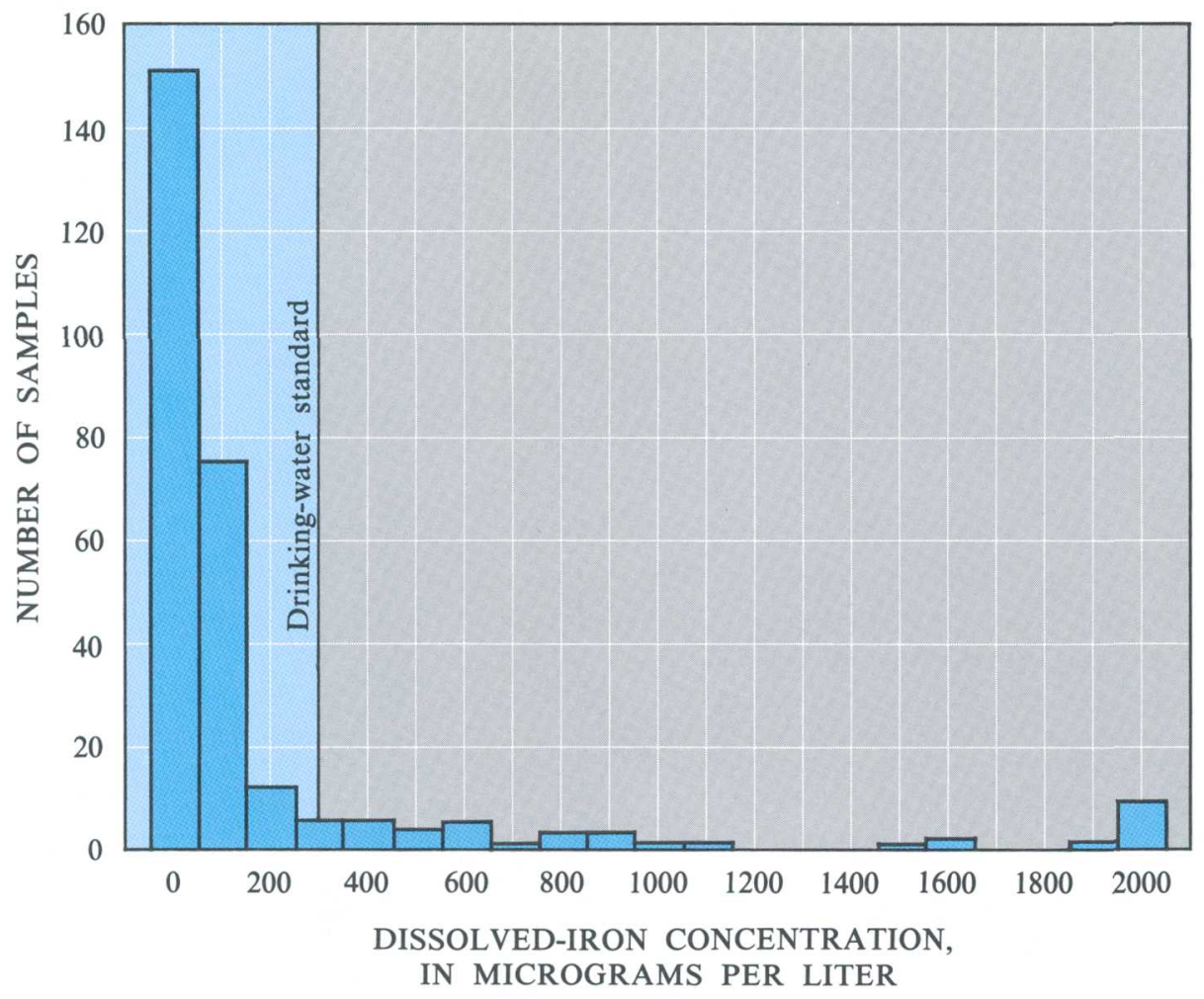

Figure 9.2-1 Iron concentrations of ground-water samples.

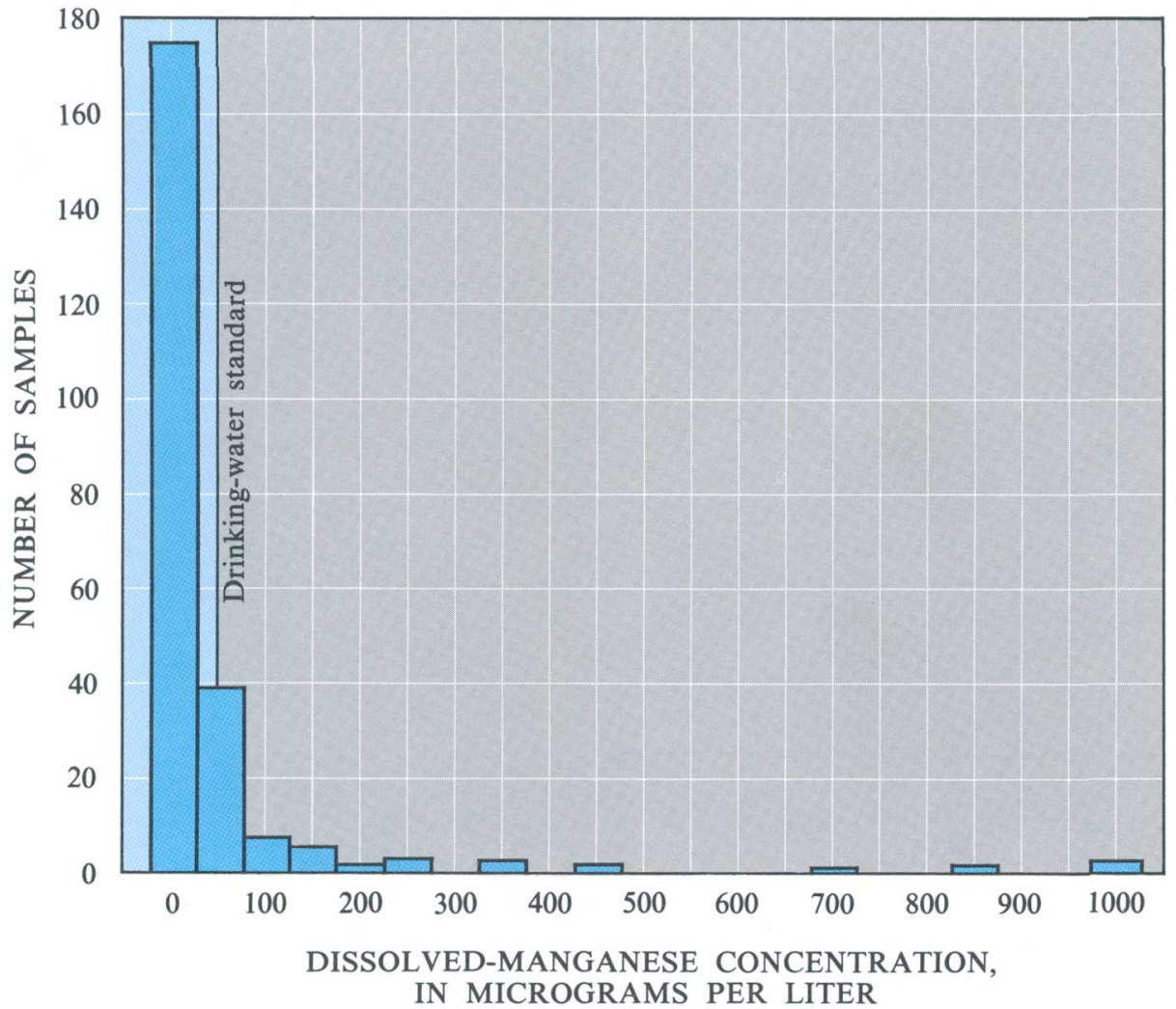

Figure 9.2-2 Manganese concentrations of ground-water samples. 


\title{
9.0 GROUND-WATER QUALITY--Continued \\ 9.3 Fluoride and Nitrate
}

\section{Fluoride and Nitrate Are Occasional Ground-Water Quality Problems}

\author{
About 19 percent of the ground-water samples analyzed for fluoride and 1 percent \\ analyzed for nitrate exceeded the National drinking-water standards.
}

Fluoride in concentrations below the drinking-water standard is desirable in drinking water because it tends to prevent cavities in the teeth of children. However, excessive fluoride mottles teeth. The drinking-water standard for fluoride is based on the annual average of the maximum daily air temperature. In a warm area it is assumed that people will drink more water, therefore the maximum recommended fluoride concentration is less than the concentrations recommended for a colder area. Assuming an annual average maximum daily air temperature of about 56 degrees Fahrenheit, the National Intermim Primary Drinking Water Regulations (U.S. Environmental Protection Agency, 1975, p. 59570) recommended a maximum fluoride concentration of 2.2 $\mathrm{mg} / \mathrm{L}$ (milligrams per liter). About 19 percent of the ground-water samples collected in the area exceeded this concentration as shown by the histogram in figure 9.3-1.

For the watering of livestock the National Academy of Sciences and National Academy of Engineering (1973, p. 312) recommends a maximum fluoride concentration of $2.0 \mathrm{mg} / \mathrm{L}$. However, the same authority acknowledges recent reports which state that fluoride concentrations well in excess of $2.0 \mathrm{mg} / \mathrm{L}$ caused no animal health problems. They also state that even though $2 \mathrm{mg} / \mathrm{L}$ may cause tooth mottling, a several-fold increase would be required to cause other injurious effects.

The National Interim Primary Drinking Water Regulations (U.S. Environmental Protection Agency, 1975 , p. 59570) list a maximum permissible nitrate, concentration of $10 \mathrm{mg} / \mathrm{L}$ expressed as nitrogen. (Expressed as nitrate, the maximum permissible concentration is $45 \mathrm{mg} / \mathrm{L}$.) Although only 1 percent (figure 9.3-2) of the nitrate analyses exceeded the standard, these occurrences are of concern if the water is used for domestic supply. Fatal poisoning of infants is possible if they ingest water with nitrate (as nitrogen) concentrations in excess of the $10-\mathrm{mg} / \mathrm{L}$ standard. Boiling the water does not alleviate the nitrate problem but rather makes it worse by concentrating the nitrate. Nitrate essentially is harmless unless converted to nitrite. Unfortunately, the stomachs of young infants (less than 3 months old) often have the conditions necessary to bacterially convert nitrate to nitrite. Nitrite absorbed into the bloodstream combines with hemoglobin which is then no longer able to transport oxygen. This condition, methemogobinemia, if severe enough, is fatal.

High nitrate concentrations are frequently found in shallow wells which have been contaminated from drainage from barnyard, feedlot, or septic-tank drainage. Nitrate fertilization for agriculture and lawns may also buildup nitrate concentrations of ground water. Another possible source of nitrates in ground water is residue from blasting if ammonium nitrate is used.

All classes of livestock that have been studied can tolerate up to $300 \mathrm{mg} / \mathrm{L}$ nitrate as nitrogen. To provide a margin of safety, however, the National Academy of Sciences and National Academy of Engineering recommend $(1973$, p. 315$)$ a maximum concentration of 100 $\mathrm{mg} / \mathrm{L}$ of nitrate plus nitrite nitrogen 


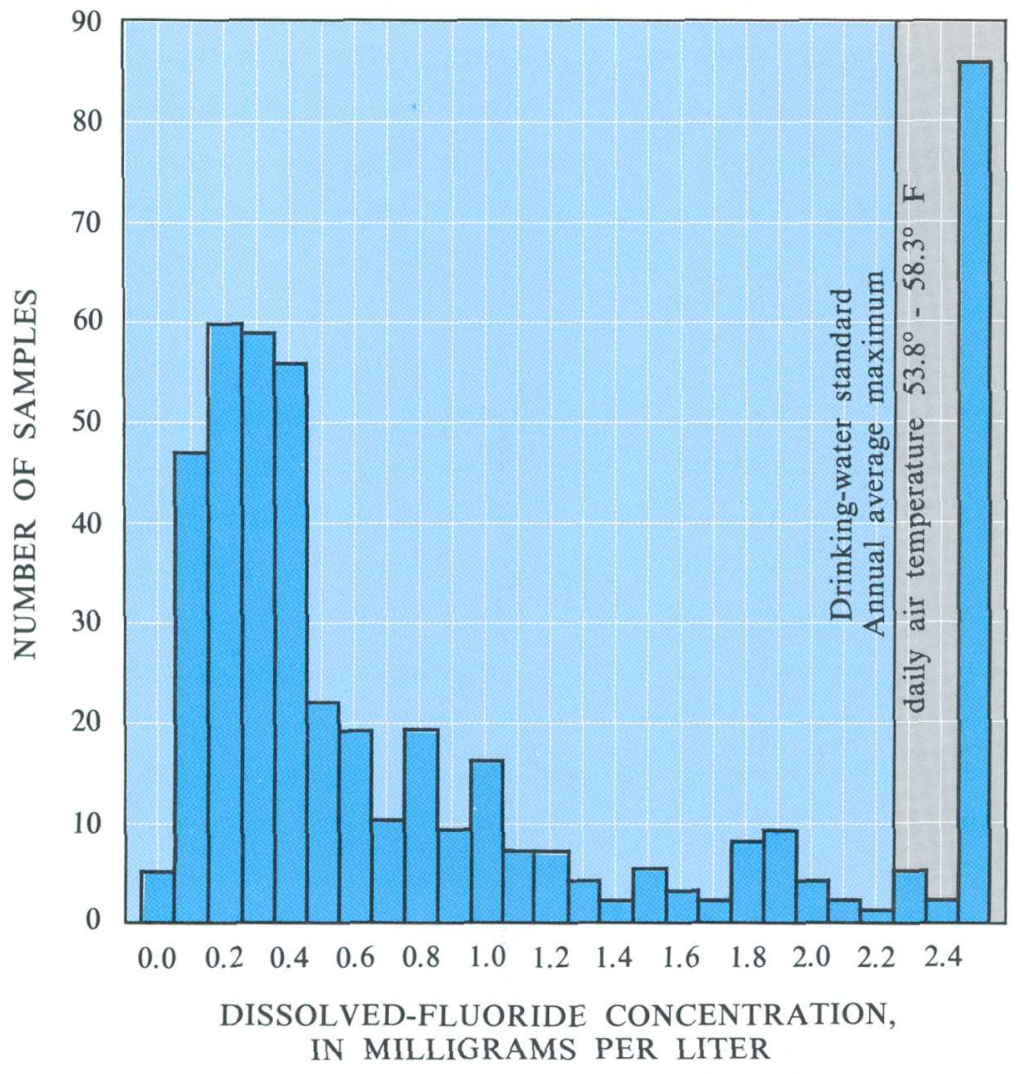

Figure 9.3-1 Fluoride concentrations of ground-water samples.

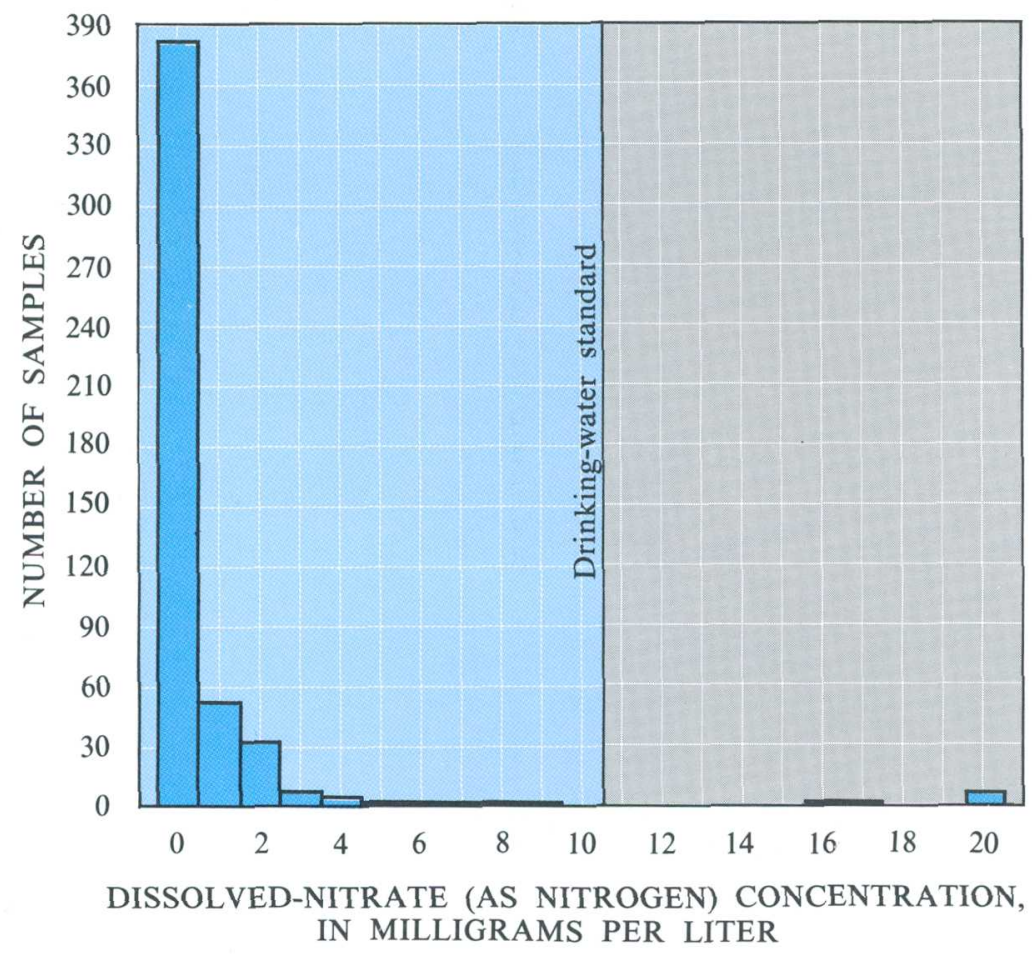

Figure 9.3-2 Nitrate concentrations of ground-water samples. 



\section{National Water-Resource Data and Information are Available from Four Sources at the Federal Level}

\section{Water data are collected in coal areas by a large number of organizations in response to a wide variety of missions and needs.}

Three activities within the U.S. Geological Survey help identify and improve access to the vast amount of existing water data.

(1) The National Water Data Exchange (NAWDEX) indexes the water data available from over 400 organizations and serves as a central focal point to help those in need of water data to determine what information already is available.

(2) The National Water Data Storage and Retrieval System (WATSTORE) serves as the central repository of water data collected by the U.S. Geological Survey and contains large volumes of data on the quantity and quality of both surface and ground waters.
(3) The Office of Water Data Coordination (OWDC) coordinates Federal water-data acquisition activities and maintains a "Catalog of Information on Water Data." To assist in identifying available water-data activities in coal provinces of the United States, special indexes to the catalog are being printed and made available to the public.

The U.S. Environmental Protection Agency operates a Water Quality Control Information System which includes a data base called STORET. This data base is used for the STORage and RETrieval of data relating to the quality of water in waterways within and contiguous to the United States.

More detailed explanations of these four activities are given in Sections 10.2, 10.3, 10.4, and 10.5. 


\title{
10.0 WATER-DATA SOURCES--Continued 10.2 National Water-Data Exchange (NAWDEX)
}

\section{NAWDEX Simplifies Access to Water Data}

\author{
The National Water-Data Exchange (NAWDEX) is a nationwide program managed by the \\ U.S. Geological Survey to assist users of water data or water-related data in \\ identifying, locating, and acquiring needed data.
}

NAWDEX is a national confederation of waterorientated organizations working together to make their data more readily accessible and to facilitate a more efficient exchange of water data.

Services are available through a Program Office located at the U.S. Geological Survey's National Center in Reston, Virginia, and a nationwide network of Assistance Centers located in $\mathbf{4 5}$ states and Puerto Rico, which provide local and convenient access to NAWDEX facilities (see fig. 10.2-1). A directory is available on request that provides names of organizations and persons to contact, addresses, telephone numbers, and office hours for each of these locations [Directory of Assistance Centers of the National Water-Data Exchange (NAWDEX), U.S. Geological Survey Open-File Report 79-423 (revised)].

NAWDEX can assist any organization or individual in identifying and locating needed water data and referring the requestor to the organization that retains the data required. To accomplish this service, NAWDEX maintains a computerized Master Water-Data Index (fig. 10.2-2), which identifies sites for which water data are available, the type of data available for each site, and the organization retaining the data. A Water-Data Sources Directory (fig. 10.2-3) also is maintained that identifies organizations that are sources of water data and the locations within these organizations from which data may be obtained. In addition NAWDEX has direct access to some large water-data bases of its members and has reciprocal agreements for the exchange of services with others.

Charges for NAWDEX services are assessed at the option of the organization providing the requested data or data service. Search assistance services are provided free by NAWDEX to the greatest extent possible. Charges are assessed, however, for those requests requiring computer cost, extensive personnel time, duplicating services, or other costs encountered by NAWDEX in the course of providing services. In all cases, charges assessed by NAWDEX Assistance Centers will not exceed the direct costs incurred in responding to the data request. Estimates of cost are provided by NAWDEX upon request and in all cases where costs are anticipated to be substantial.
For additional information concerning the NAWDEX program or its services contact:

\author{
Program Office \\ National Water Data Exchange \\ (NAWDEX) \\ 421 National Center \\ 12201 Sunrise Valley Drive \\ Reston, VA 22092 \\ Telephone: (703) 860-6031 \\ FTS 928-6031 \\ Hours: 7:45-4:15 EST \\ District Chief \\ U.S. Geological Survey, WRD \\ 2120 Capitol Ave., Room 4006 \\ P.O. Box 1125 \\ Cheyenne, WY 82003 \\ Telephone: (307) 772-2153 \\ FTS 328-2153 \\ District Chief \\ U.S. Geological Survey, WRD \\ Mail Stop 415, Box 25046 \\ Bldg. 53,Denver Federal Center \\ Lakewood, CO 80225 \\ Telephone: (303) 236-5092 \\ FTS 776-5092 \\ District Chief \\ U.S. Geological Survey, WRD \\ 230 Collins Road \\ Boise, ID 83702 \\ Telephone: (208) 334-1750 \\ FTS 554-1750 \\ District Chief \\ U.S. Geological Survey, WRD \\ Room 1016, Administration Building \\ 1745 West 1700 South \\ Salt Lake City, UT 84104 \\ Telephone: (801) 524-5663 \\ FTS 588-5663
}




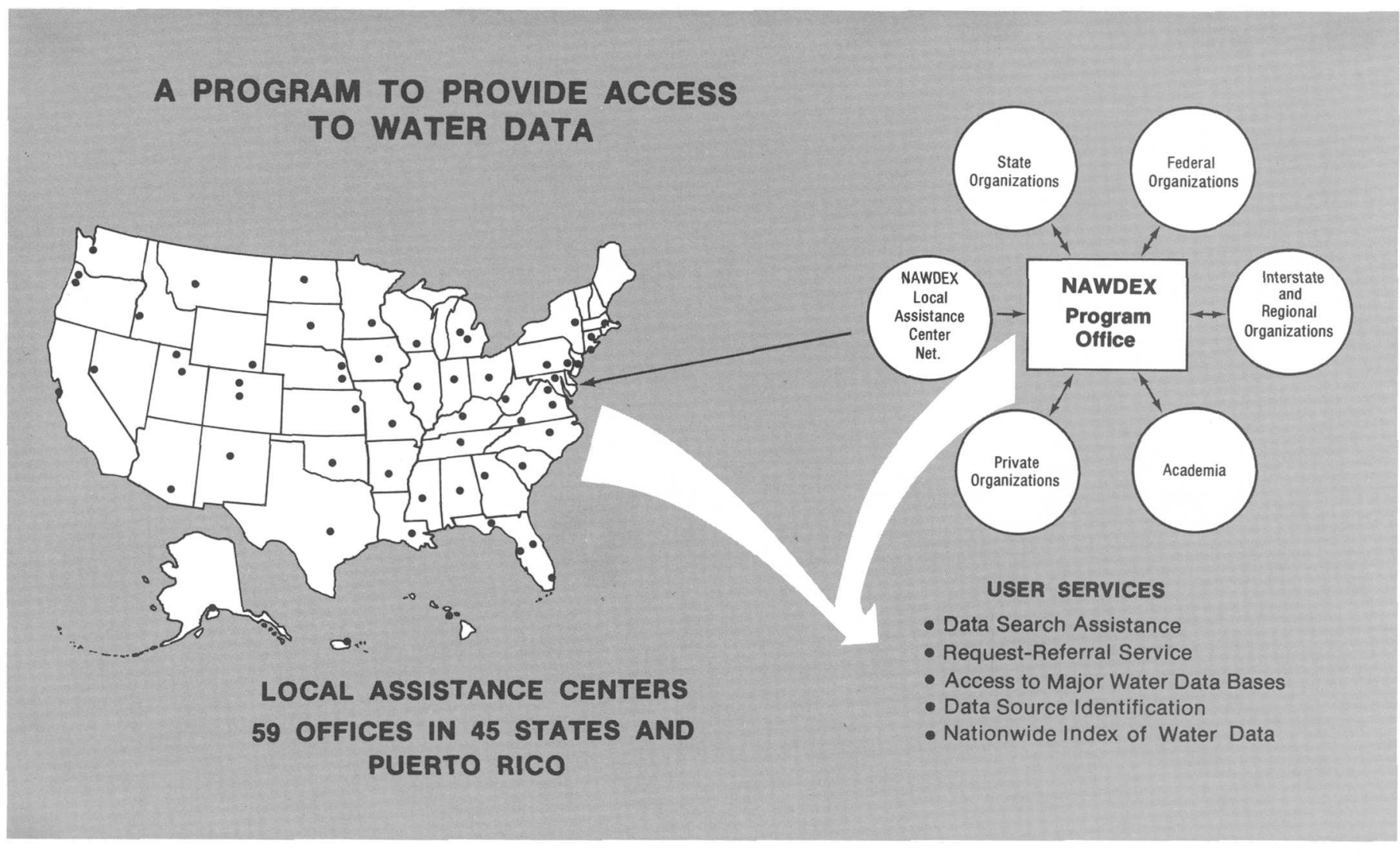

Figure 10.2-1 Access to water data.

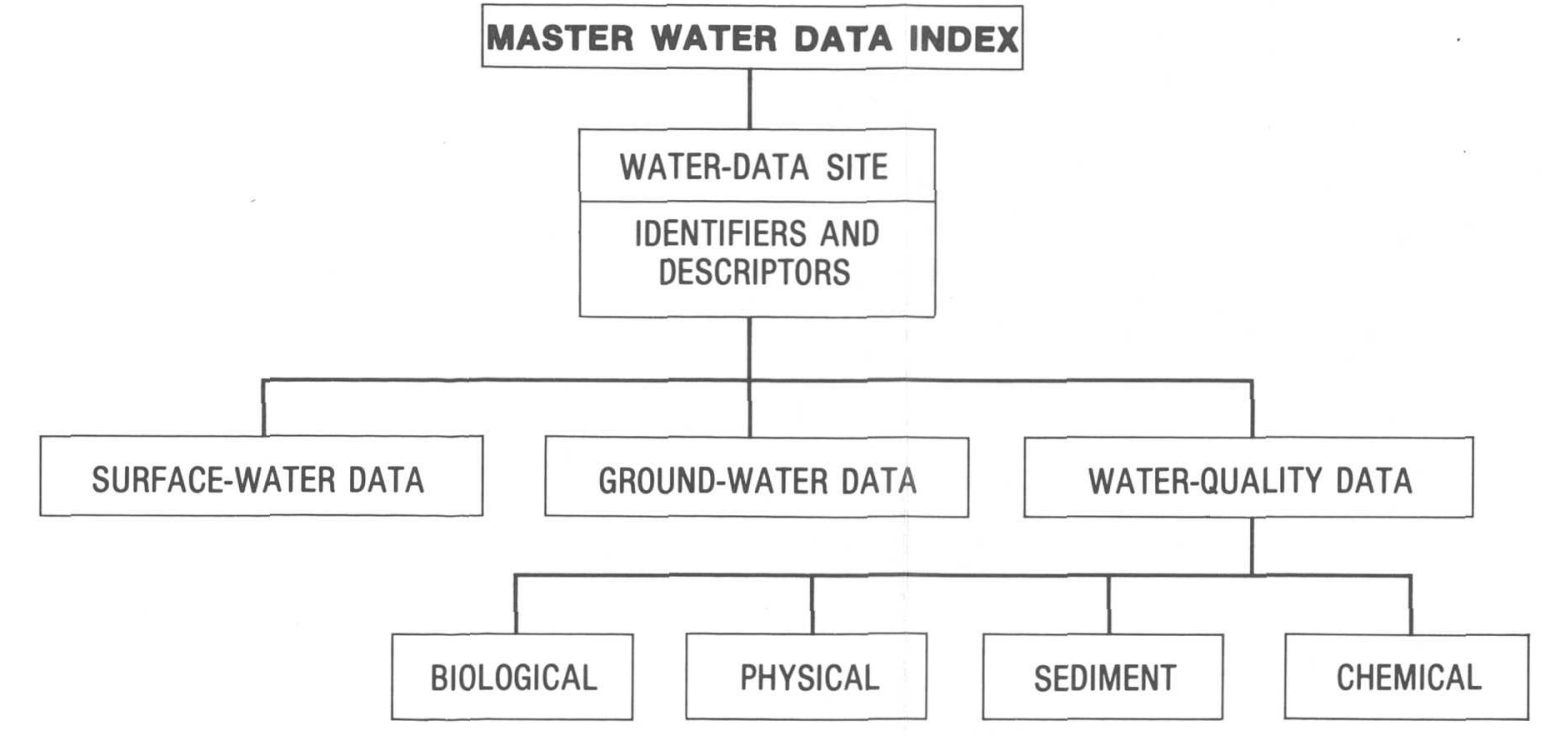

Figure 10.2-2 Master water-data index.

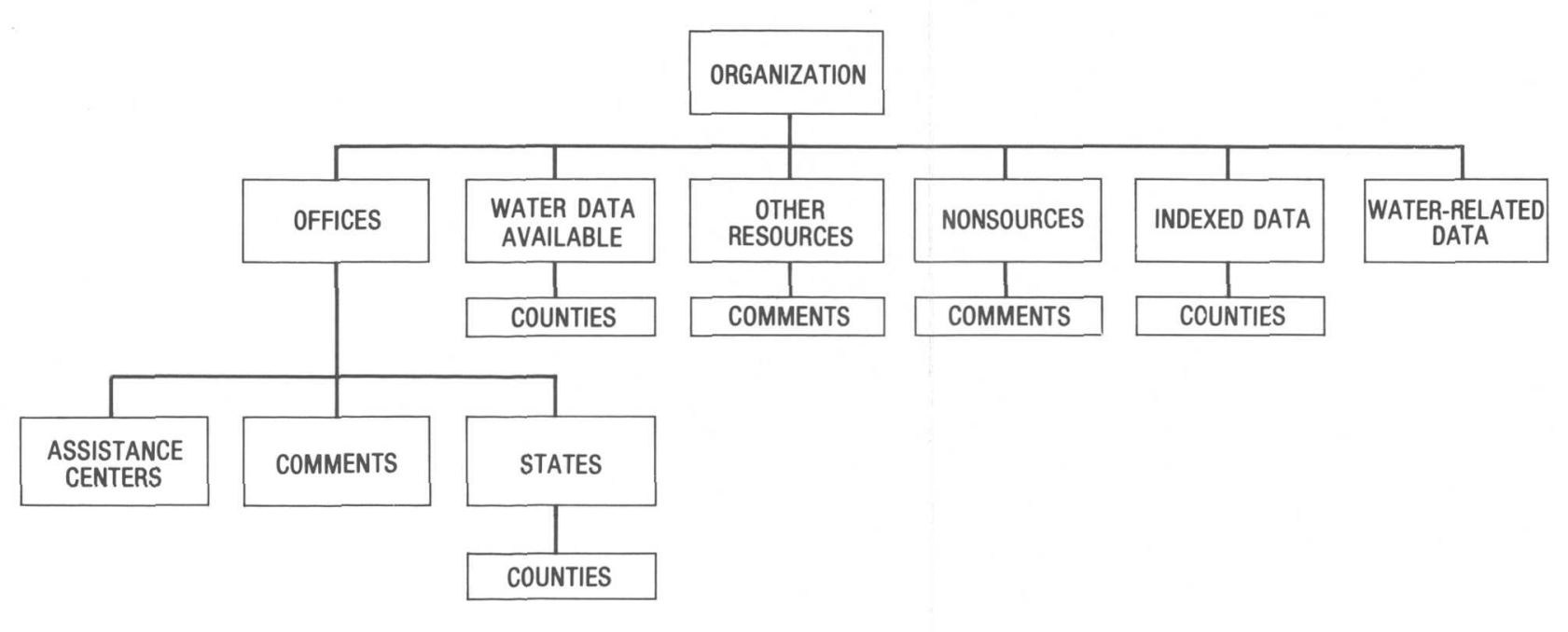

Figure 10.2-3 Water-data sources directory 


\title{
10.0 WATER-DATA SOURCES--Continued 10.3 WATSTORE
}

\section{WATSTORE Automated Data System}

\author{
The National Water-Data Storage and Retrieval System (WATSTORE) of the \\ U.S. Geological Survey provides computerized procedures and techniques \\ for processing water data and provides effective and efficient management \\ of data-releasing activities
}

The National Water-Data Storage and Retrieval System (WATSTORE) was established in November 1971 to computerize the U.S. Geological Survey's existing water-data system and to provide for more effective and efficient management of its data-releasing activities. The system is operated and maintained on the central computer facilities of the Survey at its National Center in Reston, Virginia. Data may be obtained from WATSTORE through the Water Resources Division's 46 district offices. General inquiries about WATSTORE may be directed to any of the following offices:

Chief Hydrologist

U.S Geological Survey

437 National Center

Reston, VA 22092

District Chief

U.S. Geological Survey, WRD

2120 Capitol Ave., Room 4006

P.O. Box 1125

Cheyenne, WY 82008)

District Chief

U.S. Geological Survey, WRD

Mail Stop 415, Box 25046

Bldg. 53, Denver Federal Center

Lakewood, CO 80225

District Chief

U.S. Geological Survey, WRD

230 Collins Road

Boise, ID 83702

District Chief

U.S. Geological Survey, WRD

Room 1016, Administration Building

1745 West 1700 South

Salt Lake City, UT 84104

The Geological Survey currently (1983) collects data at approximately 17,000 stage- or discharge-gaging stations, 5,200 surface-water quality stations, 27,000 waterlevel observation wells, and 7,400 ground-water quality wells. Each year many water-data collection sites are added and others are discontinued; thus, large amounts of diversified data, both current and historical, are amassed by the Survey's data-collection activities.
The WATSTORE system consists of several files in which data are grouped and stored by common characteristics and data-collection frequencies. The system also is designed to allow for the inclusion of additional data files as needed. Currently, files are maintained for the storage of: (1) Surface-water, quality-ofwater, and ground-water measured on a daily or continuous basis; (2) annual peak values for streamflow stations; (3) chemical analyses for surface- and ground-water sites; (4) water parameters measured more frequently than daily; and (5) geologic and inventory data for ground-water sites. In addition, an index file of sites for which data are stored in the system is also maintained (fig. 10.3-1). A brief description of each file is as follows.

Station Header File: Information pertinent to the identification, location, and physical description of nearly 220,000 sites are contained in this file. All sites for which data are stored in the Daily Values, Peak Flow, WaterQuality, and Unit Values files of WATSTORE are indexed in this file.

Daily Values File: All water-data parameters measured or observed either on a daily or on a continuous basis and numerically reduced to daily values are stored in this file. Instantaneous measurements at fixed-time intervals, daily mean values, and statistics such as daily maximum and minimum values also may be stored. This file currently contains over 200 million daily values including data on streamflow, river stages, reservoir contents, water temperatures; specific conductance, sediment concentrations, sediment discharges, and groundwater levels.

Peak Flow File: Annual maximum (peak) streamflow (discharge) and gage height (stage) values at surfacewater sites comprise this file, which currently contains over 400,000 peak observations.

Water-Quality File: Results of more than 1.4 million analyses of water samples are contained in this file. These analyses contain data for as many as 185 different constituents and physical properties that describe the chemical, physical, biological, and radiochemical characteristics of both surface and ground waters.

Unit Values File: Water parameters measured on a schedule more frequent than daily are stored in this file. 
Rainfall, stream discharge, and temperature data are ex-
amples of the types of data stored in the Unit Values File.

Ground-Water Site-Inventory File: This file is main ained within WATSTORE independent of the files discussed above, but it is cross-referenced to the WaterQuality File and the Daily Values File. It contains ventory data about wells, springs, are site location an identification, geohydrologic charalt mesurement such as water temperature. The file is designed to accommodate 225 data elements and currently contain

All data files of the WATSTORE system are main ained and managed on the central computer facilities of the Geological Survey at its National Center. However, data may be entered into and retrieved from a nationwide telecommunication network.

Remote Job Entry Sites: Almost all of the Water Resources Division's district offices are equipped with WATSTORE system. These terminals allow each site to enter data into or retrieve data from the system within an interval of several minutes to overnight, dependin remote job-entry sites is increased as the need aries.

Digital Transmission Sites: Digital recorders are used at many field locations to record values for parameters turbidity, wind direction, and chlorides. Data are recorded on 16-channel paper tape; the tape is removed from the recorder, and the data are transmitted over telephone lines to the receiver at Reston, $V$ a The data computer. Extensive testing of satellite data-collection platforms indicates their feasibility for transmitting realtime hydrologic data on a national scale. Battery operated radios are used as the conn stations anke operated currently (1983) by the Water Resources Division.

Central Laboratory System: The Water Resource Division's two water-quality laboratoles, located in 150,000 w equipped to automatically perform chemical analyses ranging from determinations of simple inorganic substances, such as chloride, to complex organic com pounds, such as pesticides. As each analysis is completed peter faclities to be stored in the Water tountral com puter facilities to be stored in the Water-Quality File of puter facilities

Water data are used in many ways by decision , in processing, storage, and retrieval capabilities, WATSTORE can provide a variety of useful products Wanging A can provide a varety of useful prodicts incurred in producing a desired product, is charged to the requestor.

Computer-Printed Tables: Users most often request data from WATSTORE in the form of tables printed by the computer. These tables may contain lists of actual data or condensed indexes that indicate the availability available to display the many types of data.

Computer-Printed Graphs: Computer-printed graph for the rapid analysis or display of data are another capability of WATSTE. Computer programs are frequency-distribution curves, X.Y point plots, site tots, and other similar items by means of line printers.

Statistical Analyses: WATSTORE interfaces with proprietary statistical package called SAS (Statistical Analysis System, 1982) to provide extensive analyses of dransformations, and correlations.

Digital Plotting: WATSTORE also makes use of software systems that prepare data for digital plotting on peripheral offline plotters available at the central com hydrographs, frequency-distribution curves, X-Y point hydrographs, frequency-distribution curves, X-Y point
plots, contour plots, and three-dimensional plots.

Data in Machine-Readable Form: Data stored in for use on other computers or for use as input to userwritten computer programs. These data are available in the standard format of the WATSTORE system or in the form of punched cards or card images on magnetic tape.

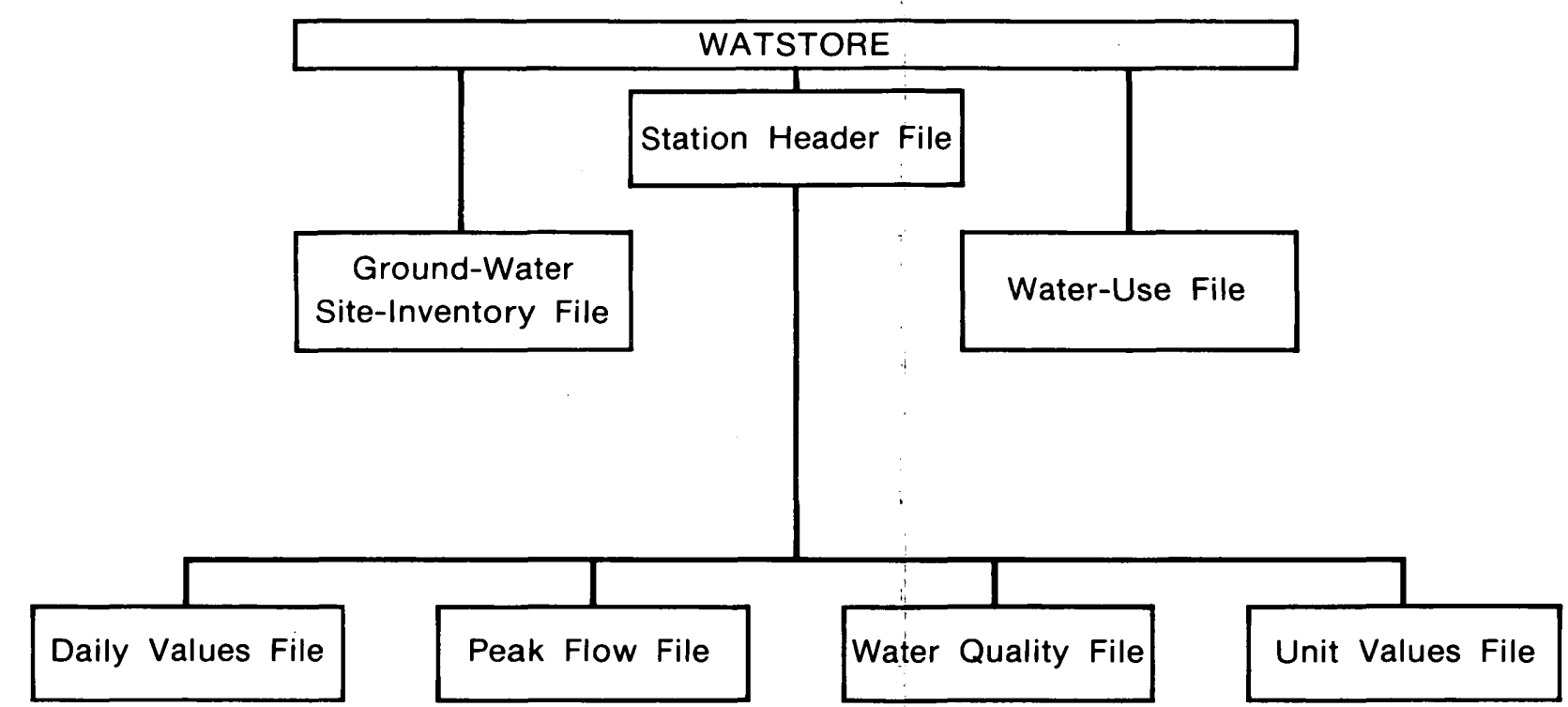

Figure 10.3-1 Index to file-stored data 


\title{
10.0 WATER-DATA SOURCES--Continued 10.4 Index to Water-Data Activities in Coal Provinces
}

\section{Water Data Indexed for Coal Provinces}

\author{
A special index, "Index to Water-Data Activities in Coal Provinces of the \\ United States," has been published by the U.S. Geological Survey's Office \\ of Water Data Coordination (OWDC).
}

The "Index to Water-Data Activities in Coal Provinces of the United States" was prepared to assist those involved in developing, managing, and regulating the Nation's coal resources by providing information on the availability of water-resources datain the major coal provinces of the United States. It is derived from the "Catalog of Information on Water Data," which is a computerized information file about water-data acquisition activities in the United States, and its territories and possessions, with some international activities included.

This special index consists of five volumes (fig. 10.4-1): Volume 1, Eastern Coal Province; Volume II, Interior Coal Province; Volume III, Northern Great Plains and Rocky Mountain Coal Provinces; Volume IV, Gulf Coast Coal Province; and Volume V, Pacific Coast and Alaska Coal Provinces. The information presented will aid the user in obtaining data for evaluating the effects of coal mining on water resources in developing plans for meeting additional water-data needs. The report does not contain the actual data; rather, it provides information that will enable the user to determine if needed data are available.

Each volume of this special index consists of four parts: Part A, Streamflow and Stage Stations; Part B, Quality of Surface-Water Stations; Part C, Quality of Ground-Water Stations; and Part D, Areal Investigations and Miscellaneous Activities. Information given for each activity in Parts A-C includes: (1) The identification and location of the station, (2) the major types of data collected, (3) the frequency of data collection, (4) the form in which the data are stored, and (5) the agency or organization reporting the activity. Part D summarizes areal hydrologic investigations and water-data activities not included in the other parts of the index. The agencies that submitted the information, agency codes, and the number of activities reported by type are shown in a table.
Those who need additional information from the Catalog file or who need assistance in obtaining water data should contact the National Water Data Exchange (NAWDEX) (See Section 10.2).

Further information on the index volumes and their availability may be obtained from:

\author{
U.S. Geological Survey \\ Water Resources Division \\ 2120 Capitol Ave., Room 4006 \\ P.O. Box 1125 \\ Cheyenne, WY 82003 \\ Telephone: (307) 772-2153 \\ FTS 328-2153
}

U.S. Geological Survey

Water Resources Division

Mail Stop 415, Box 25046

Bldg. 53, Denver Federal Center

Lakewood, CO 80225

Telephone: (303) 236-5092

FTS 776-5092

U.S. Geological Survey

Water Resources Division

230 Collins Road

Boise, ID 83702

Telephone: (208) 334-1750

FTS 554-1750

U.S. Geological Survey

Water Resources Division

Room 1016, Administration Building

1745 West 1700 South

Salt Lake City, UT 84104

Telephone: (801) 524-5663

FTS 588-5663 


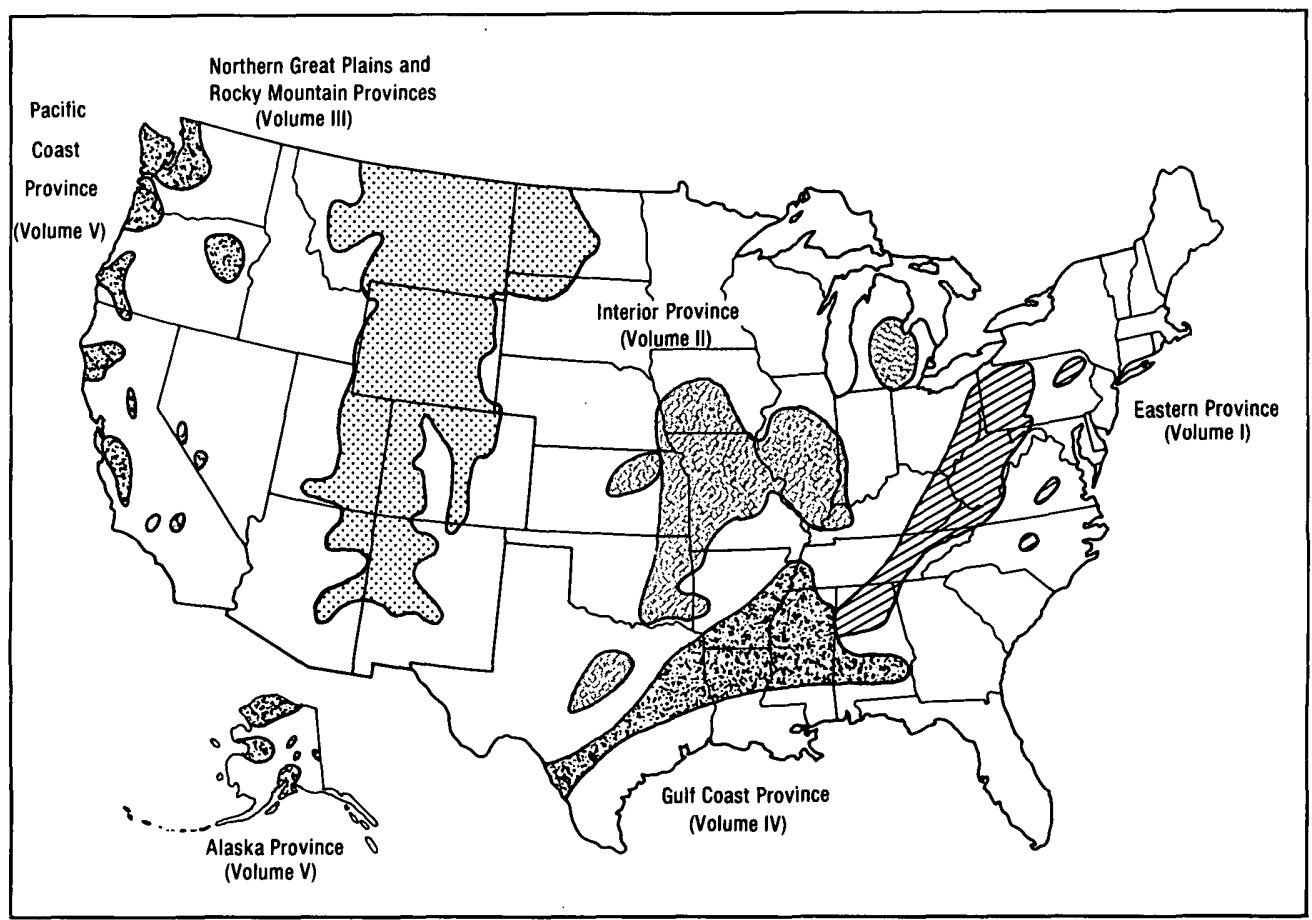

Figure 10.4-1 Index volumes and related provinces. 


\title{
10.0 WATER-DATA SOURCES--Continued 10.5 STORET
}

\section{STORET is U.S. Environmental Protection Agency Computerized Water-Data System}

\author{
STORET is the computerized water-data system that is maintained by the \\ U.S. Environmental Protection Agency. The system is used to store many \\ kinds of water-quality data.
}

STORET is a computerized water-data system maintained by the U.S. Environmental Protection Agency (EPA) for the STOrage and RETreival of data relating to the quality of water in waterways within and contiguous to the United States. The system is used to store data on water quality, water-quality standards, point sources of pollution, pollution-caused fish kills, waste-abatement needs, implementation schedules, and other water-quality related information. The Water Quality File (WQF) is the most widely used file in the STORET data base.

The data in the Water Quality File is collected through cooperative programs involving EPA, State water pollution control authorities, and other governmental agencies. The U.S. Forest Service, the U.S. Army Corps of Engineers, the U.S. Bureau of Reclamation, and the Tennessee Valley Authority all use STORET's WQF to store and retrieve data collected through their water-quality monitoring programs. Data from the U.S. Geological Survey's water-quality file in WATSTORE are automatically copied into STORET on a periodic basis.

There are 1,800 water-quality parameters defined within STORET's WQF. In 1976 there were data from over 200,000 unique collection points in the United States stored in the system. Figure 10.5-1 illustrates the groups of parameters and number of observations that are in the WQF.

State, Federal, interstate, and local government agencies can become STORET users. Information on becoming a user of the system can be obtained by contacting the EPA. The point of contact for Region VIII is:

Environmental Sciences Division

U.S. Environmental Protection Agency

1860 Lincoln Street, Suite 103

Denver, Colorado 80295

Telephone: (303) 837-2226

Source: Handbook, Water Quality Control Information System (STORET), U.S. Environmental Protection Agency, Office of Water and Hazardous Materials, Washington, D.C. 20460. 


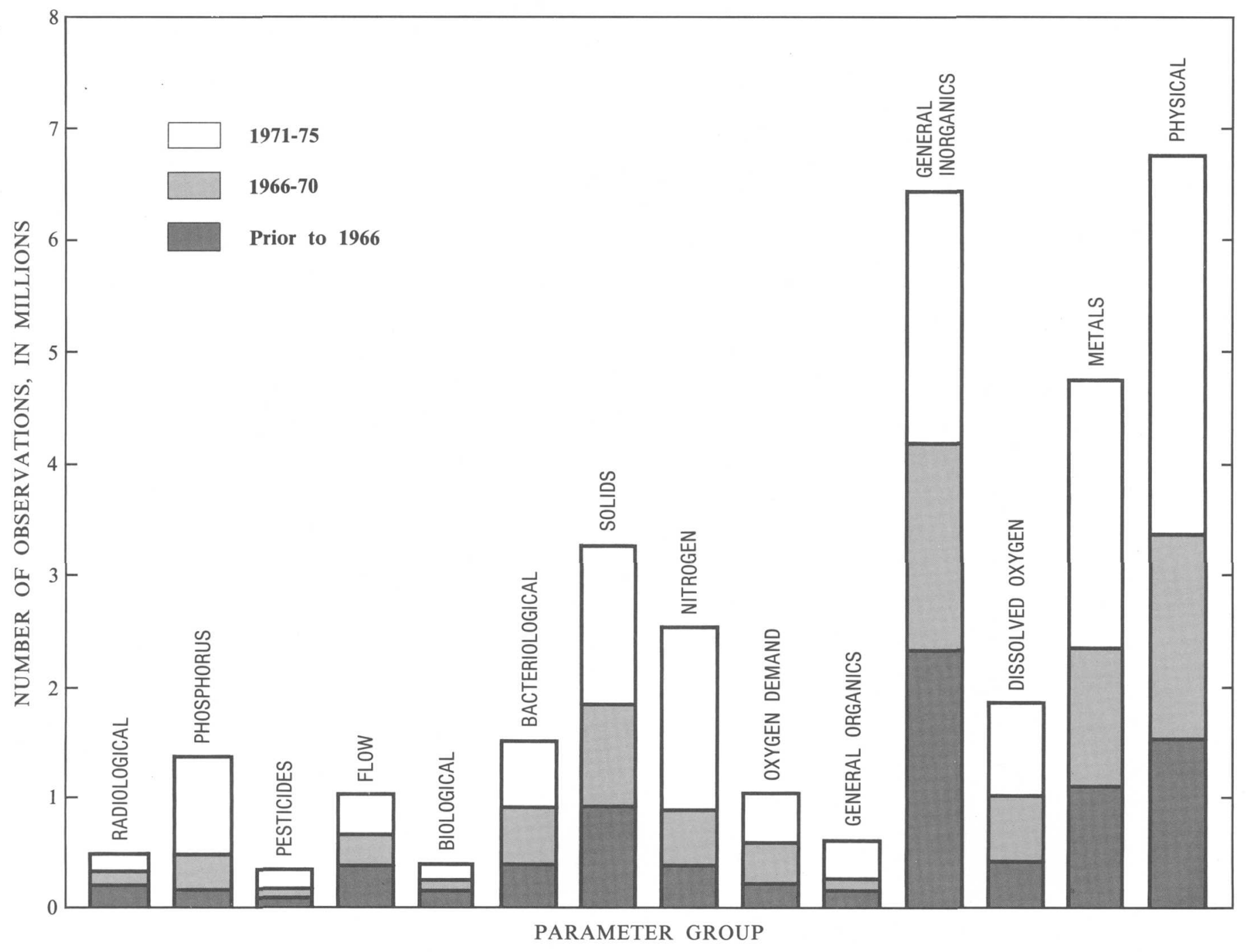

Figure 10.5-1 Parameter groups and number of observations in the Water Quality File. 

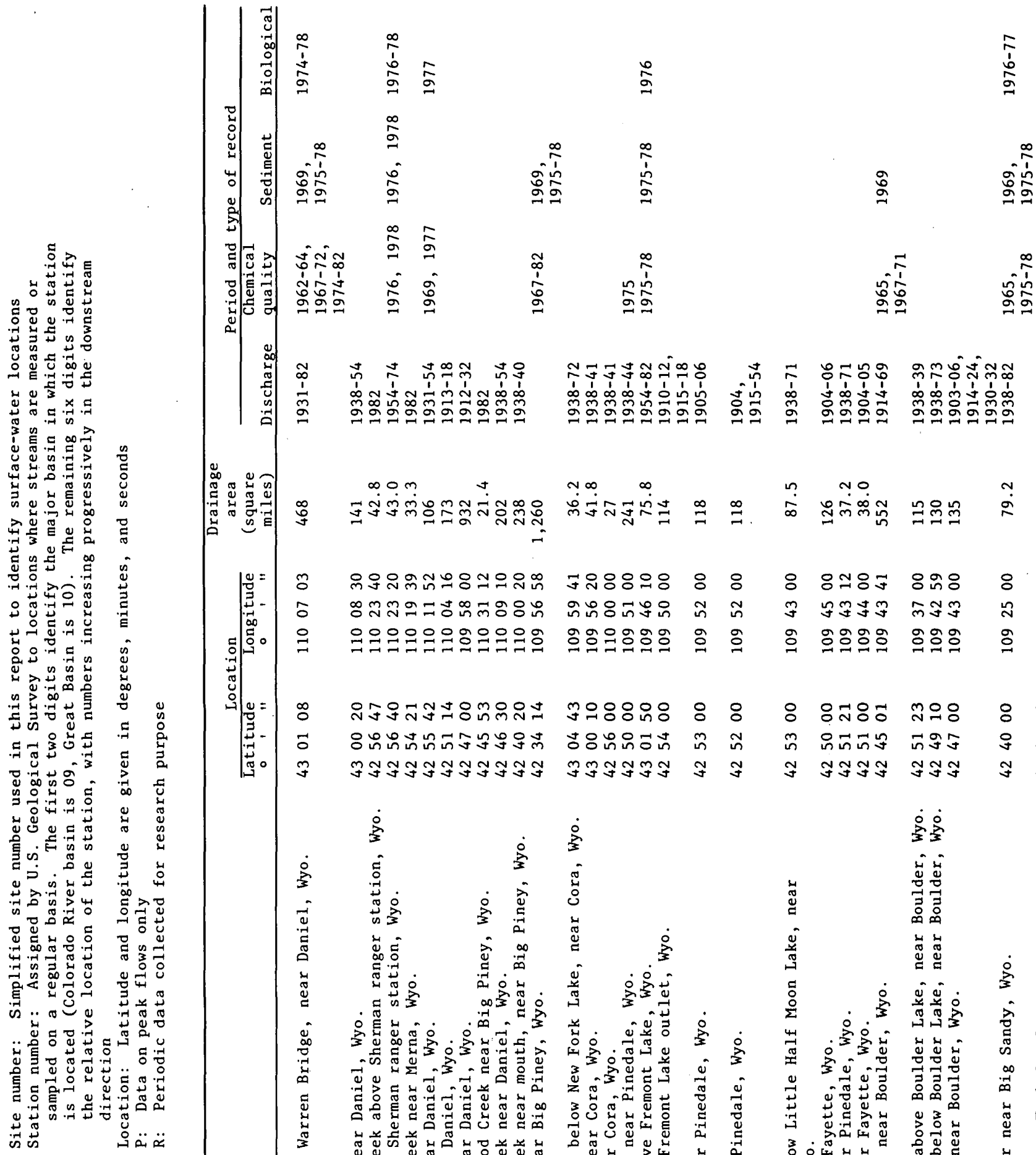

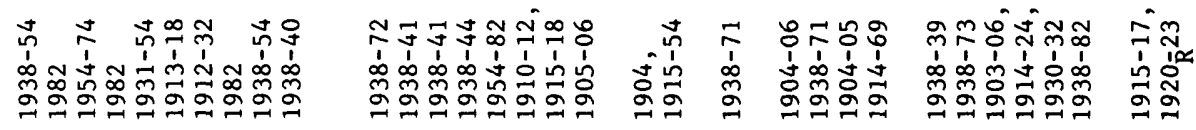

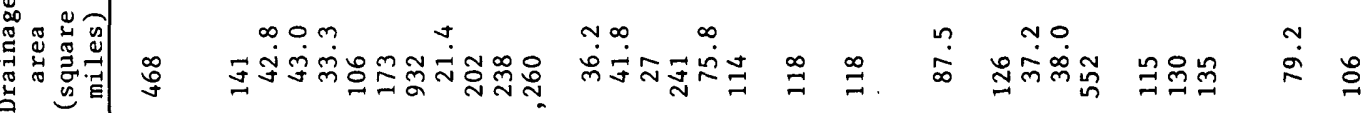

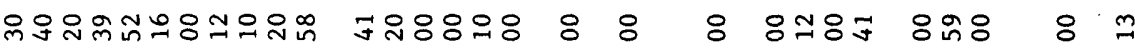

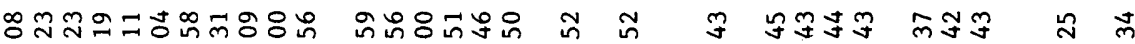

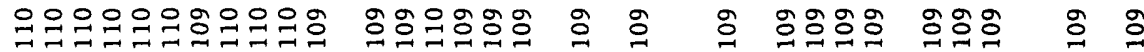

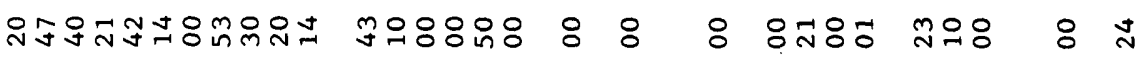

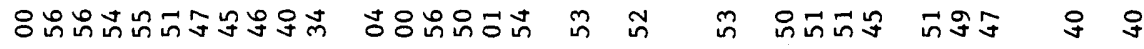

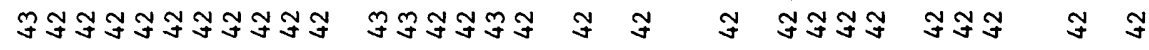

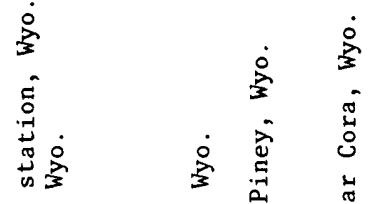

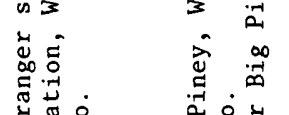

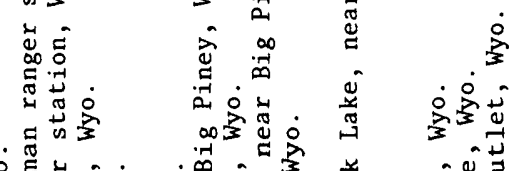

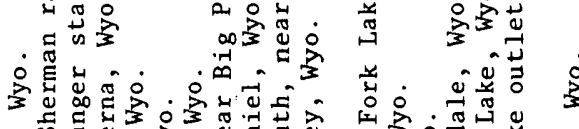

-

ปै

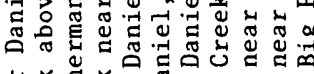

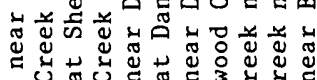

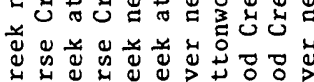

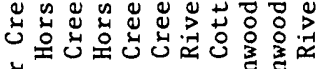

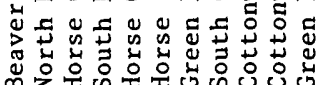

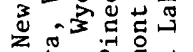

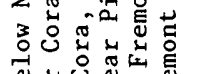

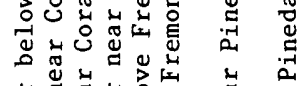

पू山्व

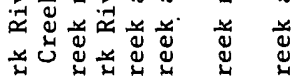

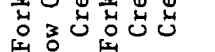

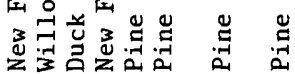

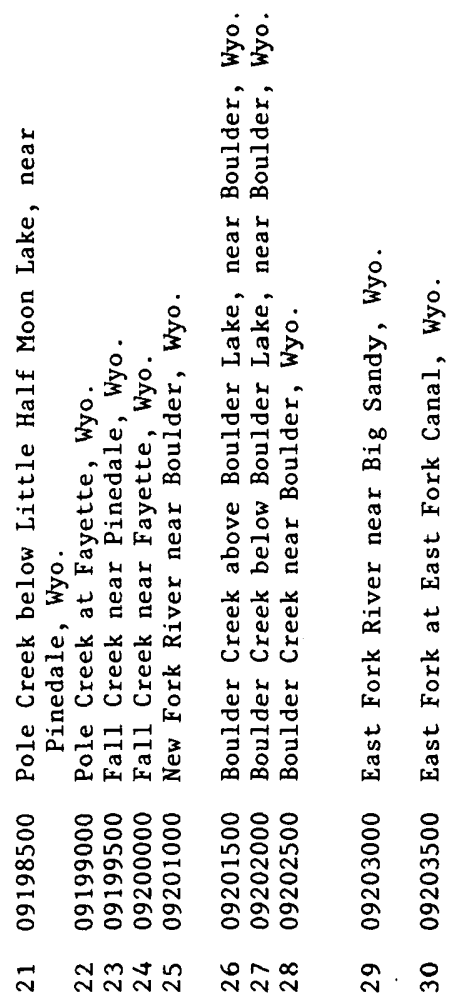




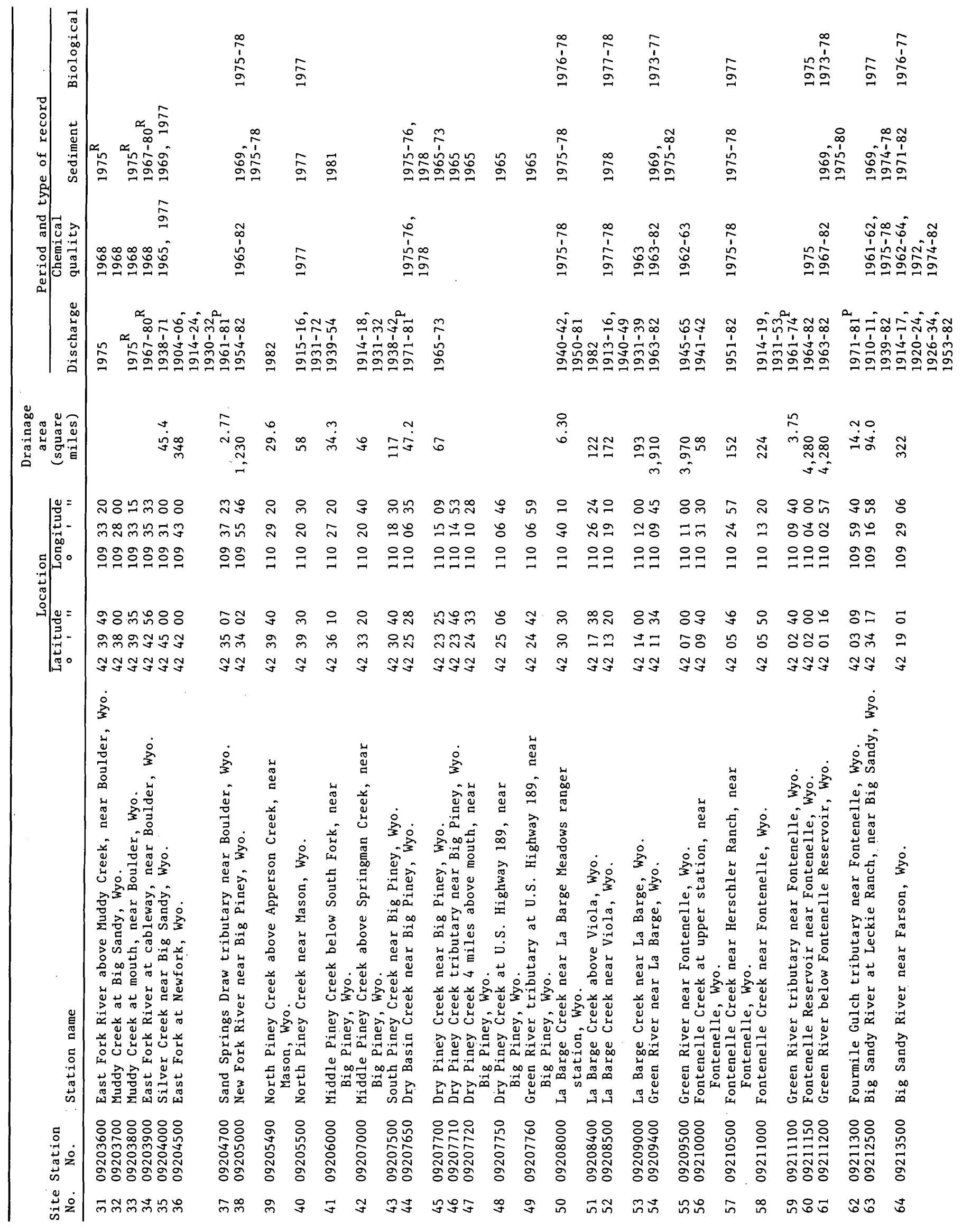




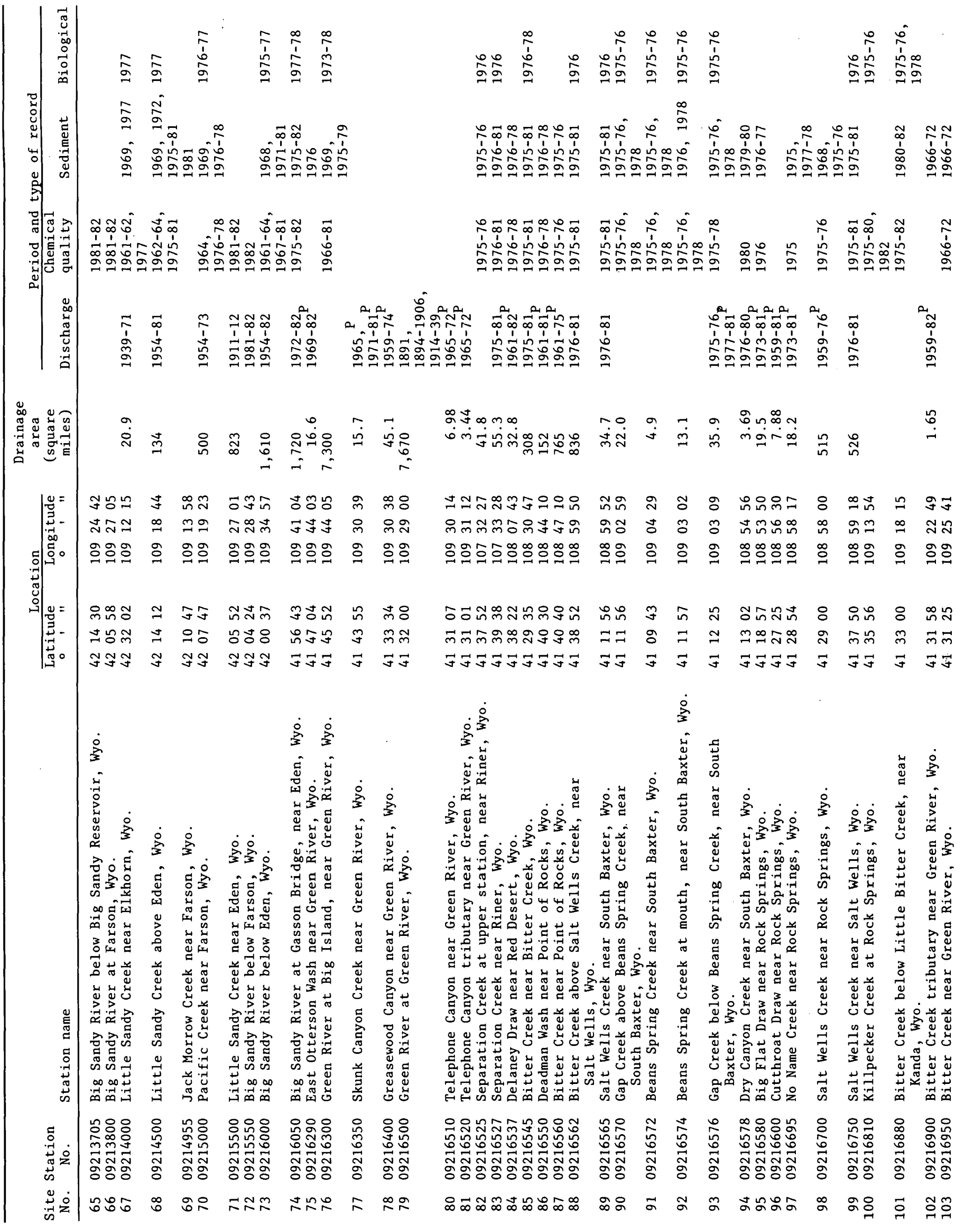




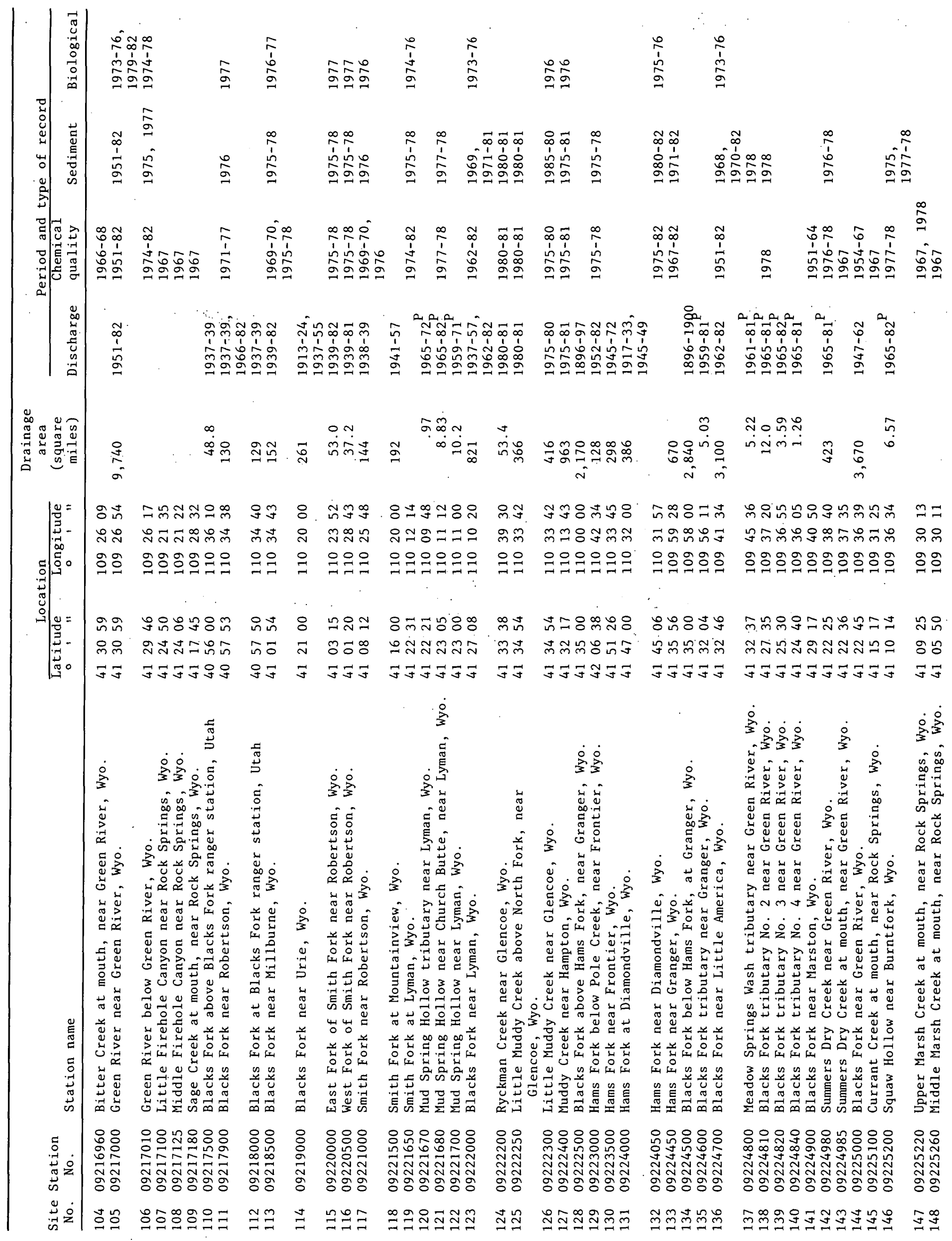




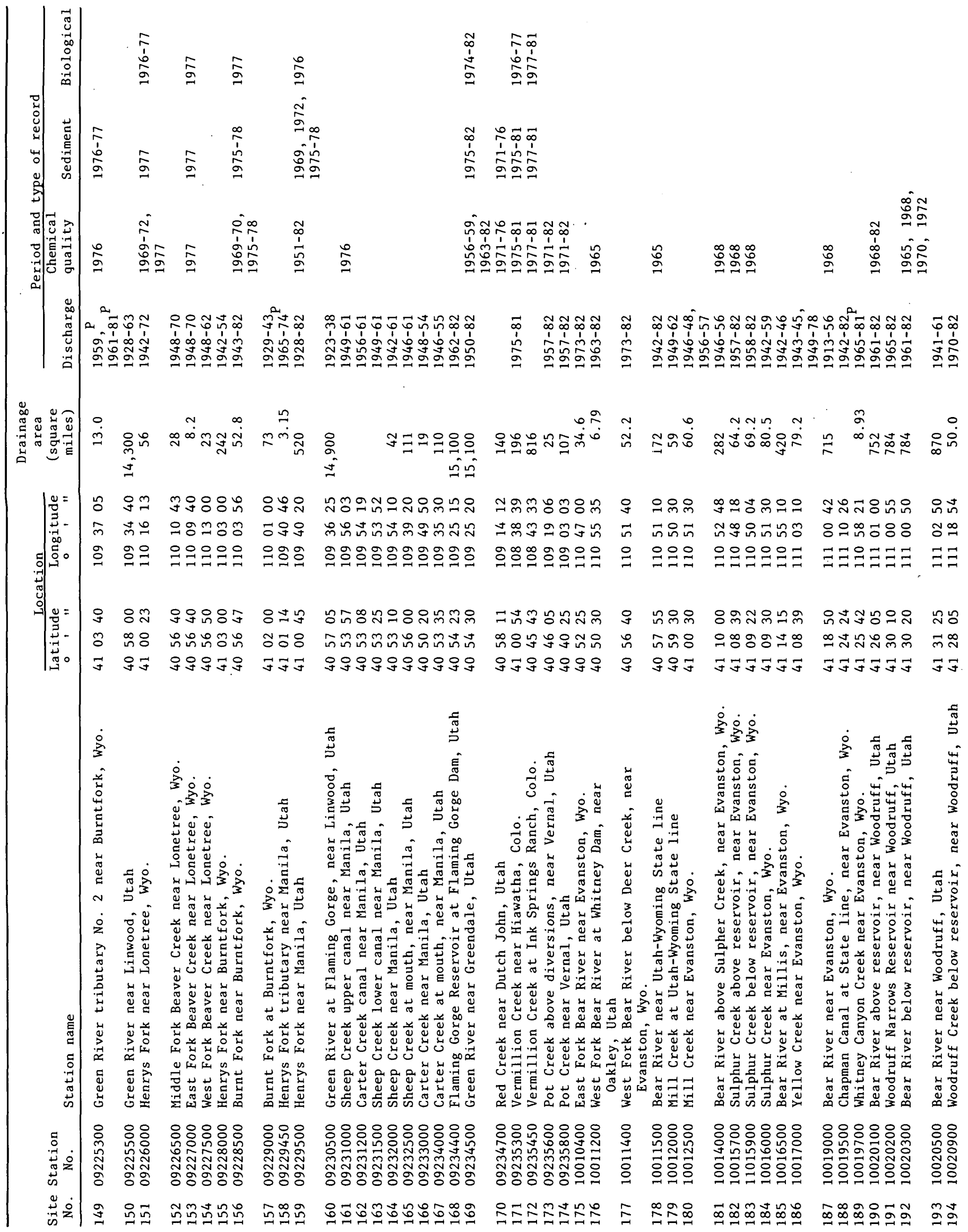




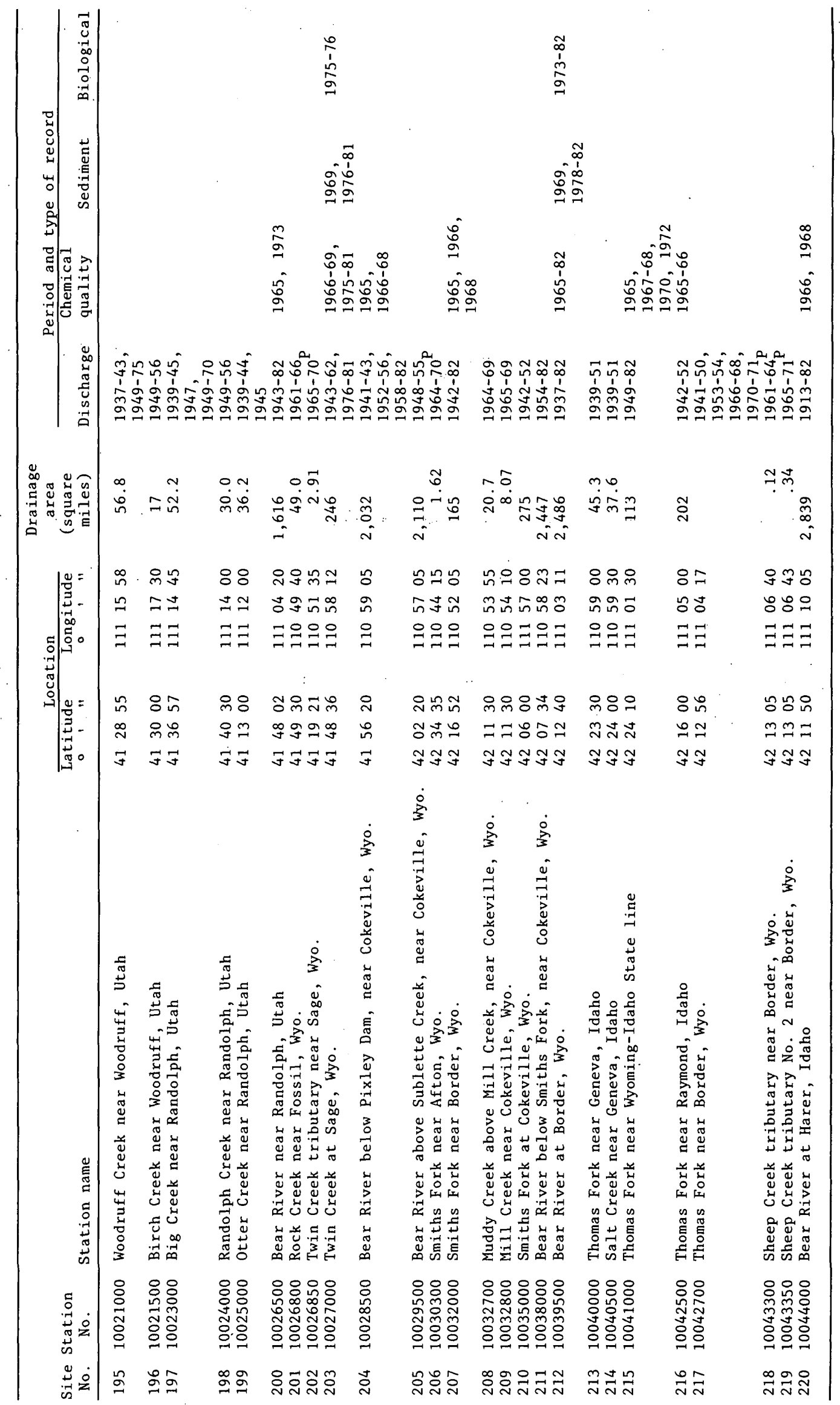




\subsection{SUPPLEMENTAL INFORMATION FOR AREA 52--Continued}

11.2 Miscellaneous Surface-Water Sites

Site number: Simplified site number used in this report to identify surface-water locations Miscellaneous site identification number: Assigned by the U.S. Geological Survey to locations where only one or a few measurements or samples have been obtained. The first six digits designate latitude of the site, the next seven digits designate longitude, and the last two digits are sequence numbers to distinguish between several sites that may be in close proximity of one another

Location: Latitude and longitude are given in degrees, minutes, and seconds

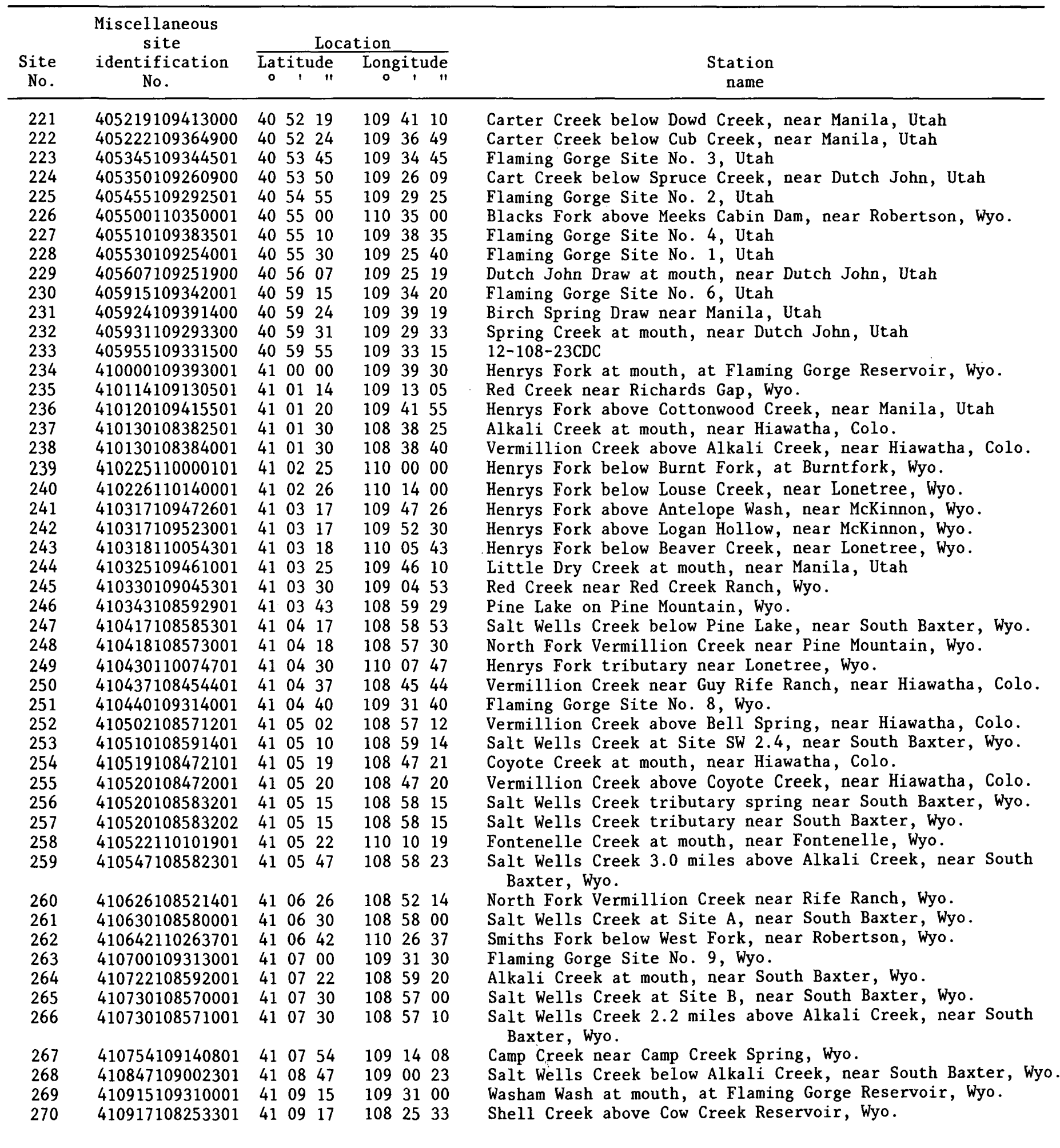




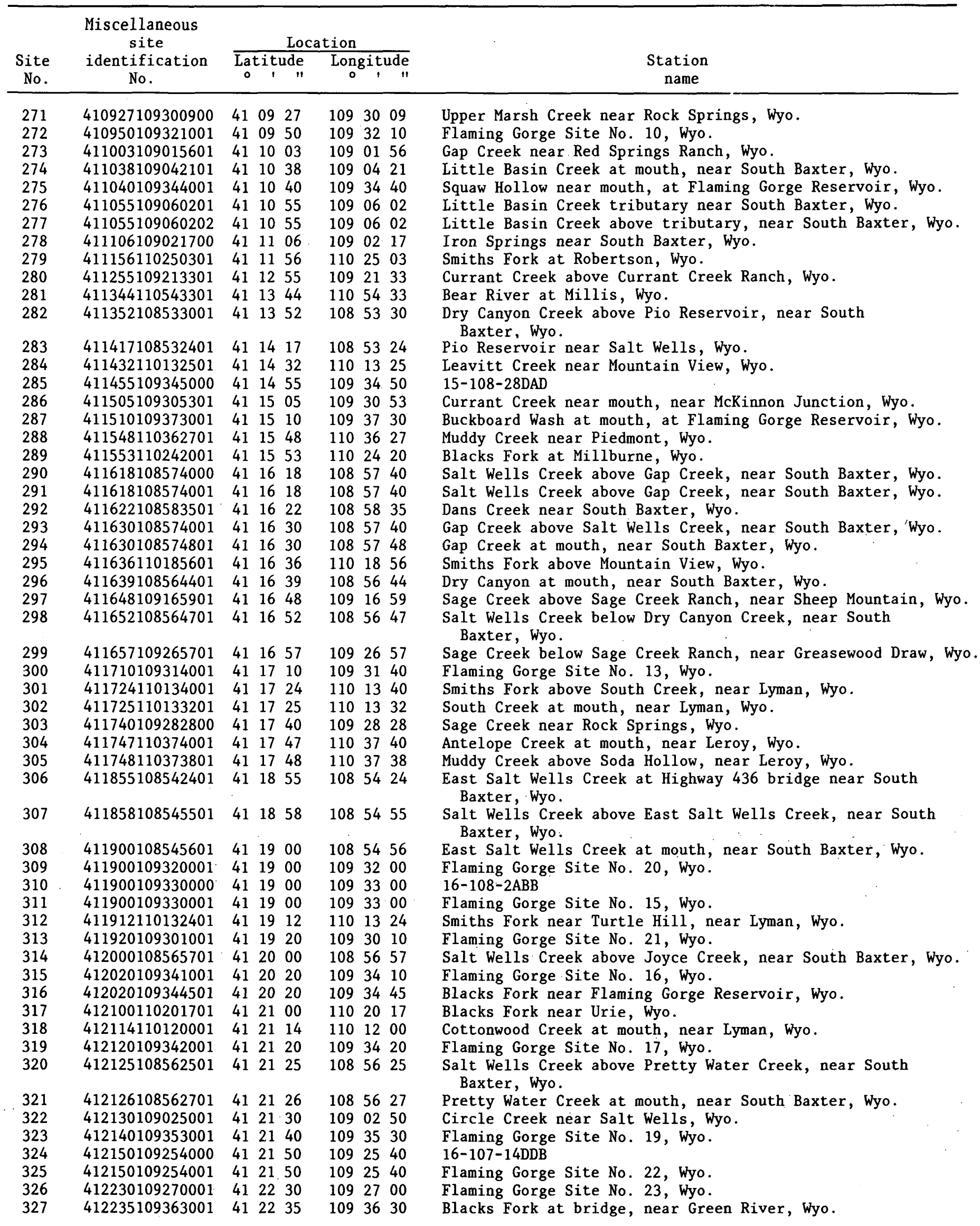




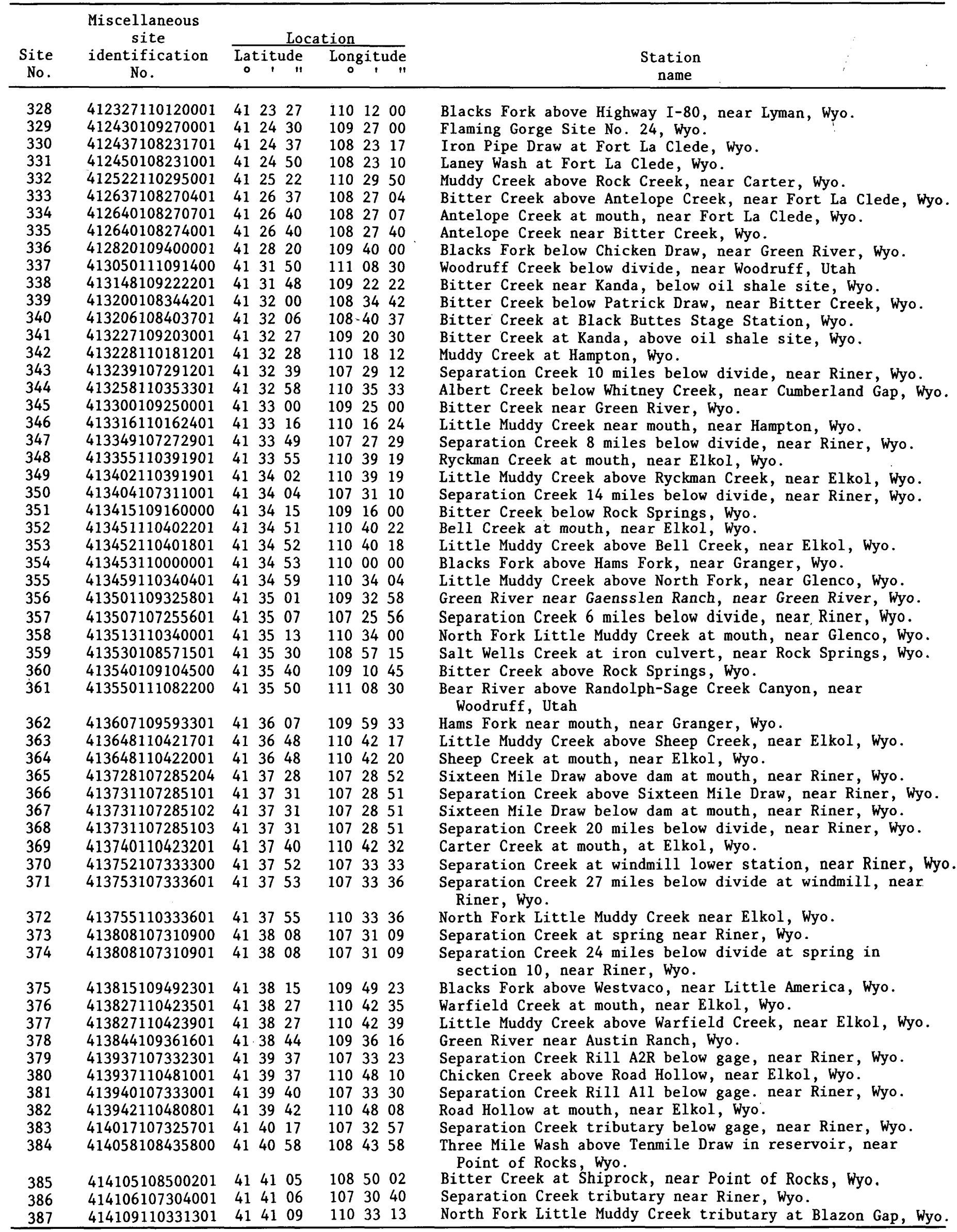




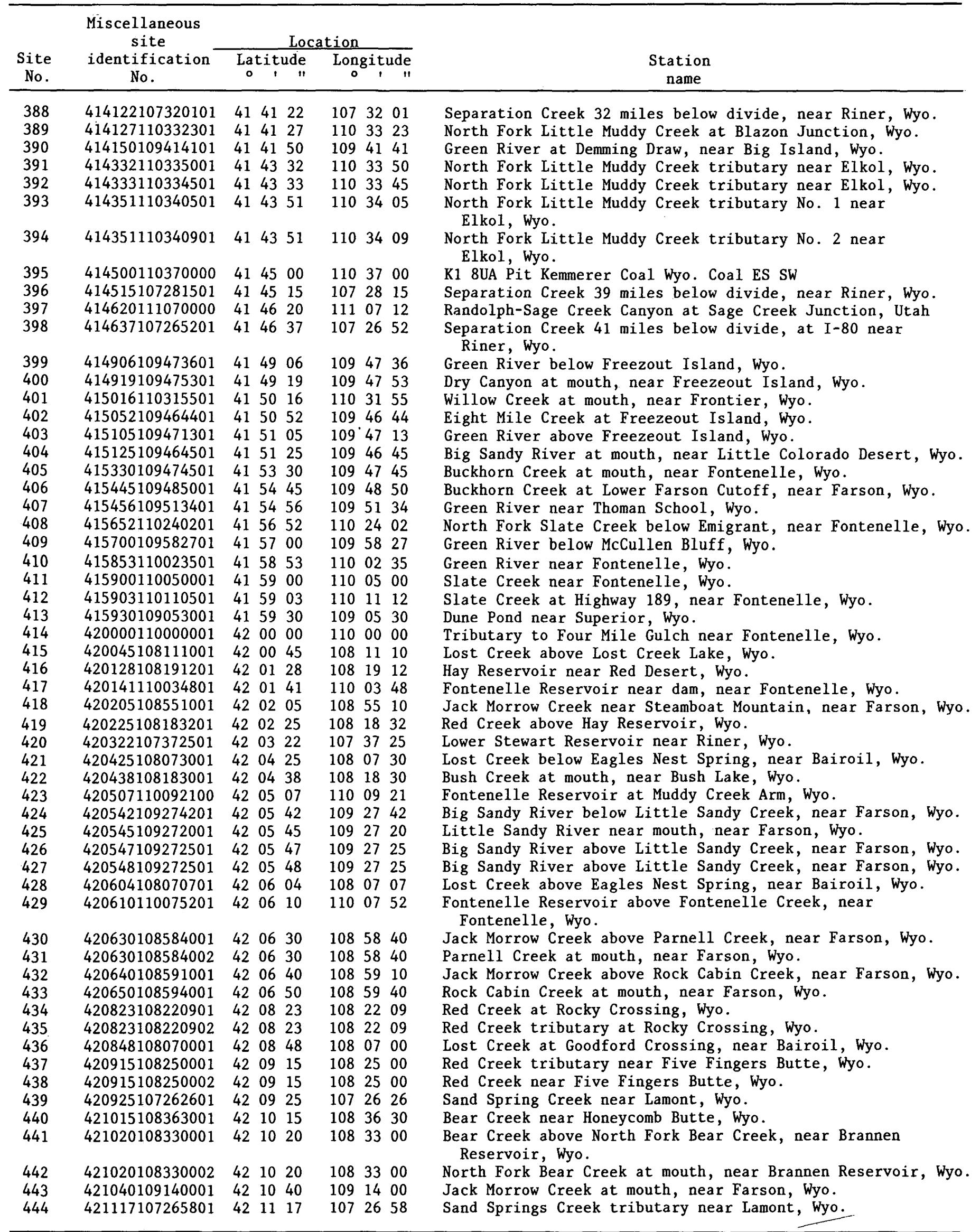




\subsection{SUPPLEMENTAL INFORMATION FOR AREA 52--Continued}

11.2 Miscellaneous Surface-Water Sites

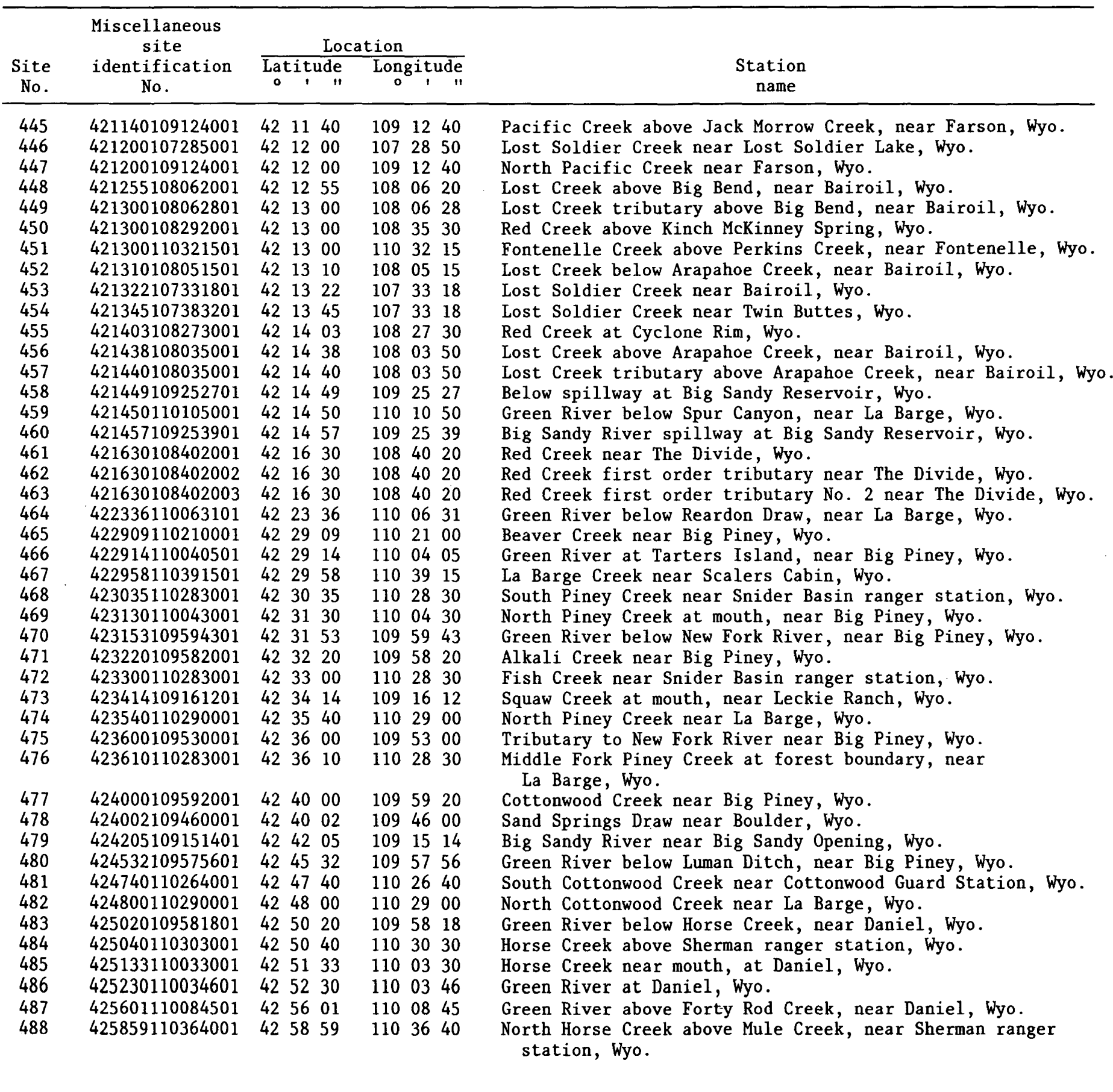


Current Observation Wells

\begin{tabular}{|c|c|c|c|c|}
\hline $\begin{array}{l}\text { Site } \\
\text { No. }\end{array}$ & $\begin{array}{l}\text { Local } \\
\text { well No. }\end{array}$ & $\begin{array}{l}\text { Well } \\
\text { depth } \\
\text { (feet) }\end{array}$ & $\begin{array}{l}\text { Geologic } \\
\text { unit }\end{array}$ & $\begin{array}{l}\text { Period } \\
\text { of record }\end{array}$ \\
\hline \multicolumn{5}{|c|}{ (Moffat County, Colorado) } \\
\hline 1 & SB01010103ACB01 & 86 & Valley fill & $1973,1977-83$ \\
\hline \multicolumn{5}{|c|}{ (Rich County, Utah) } \\
\hline $\begin{array}{l}2 \\
3 \\
4\end{array}$ & $\begin{array}{l}(A-9-7) 9 B D C-1 \\
(A-9-7) 9 C D C-1 \\
(A-9-7) 26 C D D-1\end{array}$ & $\begin{array}{l}-- \\
57 \\
--\end{array}$ & $\begin{array}{l}-- \\
-- \\
--\end{array}$ & \multirow{4}{*}{$\begin{array}{l}1948,1950-83 \\
1948-83 \\
1948,1953,1956-57 \\
1959-60,1962-83 \\
1946-51,1953-59, \\
1962-83 \\
1947-83 \\
1936-59,1961-65, \\
1961-65,1967-83 \\
1936-83\end{array}$} \\
\hline 5 & $(A-9-7) 26 C D D-2$ & 300 & -- & \\
\hline $\begin{array}{l}6 \\
7\end{array}$ & $\begin{array}{l}(A-10-7) 17 D D C-2 \\
(A-11-7) 9 C D-1\end{array}$ & $\begin{array}{l}50 \\
25\end{array}$ & -- & \\
\hline 8 & $(A-12-7) 26 B B-2$ & 6 & -- & \\
\hline \multicolumn{5}{|c|}{ (Carbon County, Wyoming) } \\
\hline 9 & $21 \mathrm{~N} 89 \mathrm{~W} 22 \mathrm{ada} 01$ & 156 & Fort Union & $1963,1965-83$ \\
\hline \multicolumn{5}{|c|}{ (Lincoln County, Wyoming) } \\
\hline $\begin{array}{l}10 \\
11 \\
12\end{array}$ & $\begin{array}{lll}23 \mathrm{~N} & 119 \mathrm{~W} & 32 \mathrm{bda} 02 \\
23 \mathrm{~N} & 120 \mathrm{~W} & 13 \mathrm{aac} 01 \\
24 \mathrm{~N} & 112 \mathrm{~W} & 08 \mathrm{cbb01}\end{array}$ & $\begin{array}{l}230 \\
142 \\
150\end{array}$ & $\begin{array}{l}\text { Terrace deposits } \\
\text { Alluvium } \\
\text { Laney Member, Green } \\
\text { River Formation }\end{array}$ & $\begin{array}{l}1962-83 \\
1955-83 \\
1962-70, \quad 1972-83\end{array}$ \\
\hline 13 & $24 \mathrm{~N}$ 119W 28aca01 & 200 & Terrace deposits & $1962-83$ \\
\hline \multicolumn{5}{|c|}{ (Sublette County, Wyoming) } \\
\hline $\begin{array}{l}14 \\
15 \\
16 \\
17 \\
18\end{array}$ & 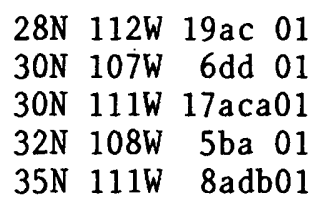 & $\begin{array}{r}153 \\
153 \\
435 \\
77 \\
39\end{array}$ & $\begin{array}{l}\text { Wasatch } \\
\text { Wasatch } \\
\text { Wasatch } \\
\text { Alluvium } \\
\text { Alluvium }\end{array}$ & $\begin{array}{ll}1965-70, & 1972-83 \\
1964-66,1968-83 \\
1965-83 \\
1965-83 \\
1965-83\end{array}$ \\
\hline \multicolumn{5}{|c|}{ (Sweetwater County, Wyoming) } \\
\hline $\begin{array}{l}19 \\
20 \\
21 \\
22 \\
23\end{array}$ & $\begin{array}{llr}18 \mathrm{~N} & 110 \mathrm{~W} & 21 \mathrm{dba} 01 \\
19 \mathrm{~N} & 95 \mathrm{~W} & 5 \mathrm{dd} 01 \\
19 \mathrm{~N} & 99 \mathrm{~W} & 6 \mathrm{dcc} 01 \\
20 \mathrm{~N} & 100 \mathrm{~W} & 25 \mathrm{dcd} 01 \\
22 \mathrm{~N} & 105 \mathrm{~W} & 7 \mathrm{aad01}\end{array}$ & $\begin{array}{r}40 \\
1,100 \\
161 \\
166 \\
99\end{array}$ & $\begin{array}{l}\text { Alluvium } \\
\text { Wasatch } \\
\text { Fort Union } \\
\text { Almond } \\
\text { Laney Member, Green } \\
\quad \text { River Formation }\end{array}$ & $\begin{array}{l}1964-83 \\
1972-83 \\
1963-83 \\
1963-83 \\
1964-83\end{array}$ \\
\hline 24 & $25 \mathrm{~N} \quad 106 \mathrm{~W} 27 \mathrm{ccd} 01$ & 60 & $\begin{array}{l}\text { Laney Member, Green } \\
\text { River Formation }\end{array}$ & $1965-83$ \\
\hline \multicolumn{5}{|c|}{ (Uinta County, Wyoming) } \\
\hline $\begin{array}{l}25 \\
26 \\
27\end{array}$ & $\begin{array}{lll}15 \mathrm{~N} & 115 \mathrm{~W} & 20 \mathrm{cba} 01 \\
15 \mathrm{~N} & 118 \mathrm{~W} & 24 \mathrm{bcb} 01 \\
16 \mathrm{~N} & 121 \mathrm{~W} & 11 \mathrm{acc} 01\end{array}$ & $\begin{array}{l}17 \\
80 \\
34\end{array}$ & $\begin{array}{l}\text { Terrace deposits } \\
\text { Wasatch } \\
\text { Terrace deposits }\end{array}$ & $\begin{array}{l}1957-83 \\
1964-83 \\
1955-83\end{array}$ \\
\hline
\end{tabular}




\subsection{SELECTED REFERENCES}

Alyea, J. D., 1980, Precipitation survey of Wyoming: Unpublished report on file in Cheyenne office of the U.S. Geological Survey, Water Resources Division, $38 \mathrm{p}$.

Baldwin, H. L., and McGuiness, C. L., 1963, A primer on ground water: U.S. Geological Survey, 26 p.

Baxter, G. T., and Simon, J. R., 1970, Wyoming fishes: Wyoming Game and Fish Department Bulletin No. 4, $168 \mathrm{p}$.

Berry, D. W., 1960, Geology and ground-water resources of the Rawlins area, Carbon County, Wyoming: U.S. Geological Survey Water-Supply Paper 1458, 74 p.

Bolke, E. L., 1979, Dissolved oxygen depletion and other effects of storing water in Flaming Gorge Reservoir, Wyoming and Utah: U.S. Geological Survey WaterSupply Paper 2058, $41 \mathrm{p}$.

Bradley, W. H., 1964, Geology of Green River Formation and associated Eocene rocks in southwestern Wyoming and adjacent parts of Colorado and Utah: U.S. Geological Survey Professional Paper 496-A, $86 \mathrm{p}$.

Brown, W. M., III, and Ritter, J. R., 1971, Sediment transport and turbidity in the Eel Ring Basin, California: U.S. Geological Survey Water-Supply Paper 1986, 67 p.

Calef, W., 1960, Private grazing and public lands: Chicago, The University of Chicago Press, 292 p.

Colby, B. R., 1956, Relationship of sediment discharge to streamflow: U.S. Geological Survey open-file report, $170 \mathrm{p}$.

1963, Fluvial sediments-A summary of source, transportation, deposition, and measurement of sediment discharge: U.S. Geological Survey Bulletin 1181-A, $47 \mathrm{p}$.

Craig, G. S., Jr., and Rankl, J. G., 1978, Analysis of runoff from small drainage basins in Wyoming: U.S. Geological Survey Water-Supply Paper 2056, 70 p.

Culbertson, W. C., Smith, J. W., and Trudell, L. G., 1980, Oil shale resources and geology of the Green River Formation in the Green River Basin, Wyoming: U.S. Department of Energy, Laramie Energy Technology Center Report of Investigations, $102 \mathrm{p}$.

DeLong, L. L., 1983, Water quality of streams and springs, Green River Basin-Wyoming: U.S. Geological Survey Water-Resources Investigations Report 83-4008.

Engelke, M. J., 1978, The biology of Salt Wells Creek and its tributaries, southwestern Wyoming: U.S. Geological Survey Water-Resources Investigations Report 78-121, $82 \mathrm{p}$.

Fagnant, J. A., 1962, Wyoming company preparing to send coal by wire to Utah Power and Light: Mining Engineering, v. 14, no. 8, p. 37-49.

Foss, P. O., 1960, Politics and grass: Seattle, University of Washington Press, $236 \mathrm{p}$.

Glass, G. B., 1982, Description of Wyoming coal fields and seam analysis: Keystone Coal Industry Manual, New York, McGraw-Hill, p. 660-685; Geological Survey of Wyoming Reprint 43, 29 p.
Glass, G. B., Wendell, W. G., Root, F. K., and Breckenridge, R. M., (compilers), 1975, Energy resources map of Wyoming: The Geological Survey of Wyoming, Laramie, Wyoming, scale 1:500,000.

Hanson, M. L., Heckathorn, B. R., and Rathjen, R. A., 1978, Environmental Base Working Paper: Portland, Oreg., U.S. Soil Conservation Service, Green River Basin, Wyoming, Type IV Study Working Paper, 71 p. plus 9 appendices.

Harris, E. E., and Rantz, S. E., 1964, Effect of urban growth on streamflow regimen of Permanente Creek, Santa Clara County, California: U.S. Geological Survey Water-Supply Paper 1591-B, p. B7.

Hausel, W. D., Glass, G. B., Lageson, D. R., Ver Ploeg, A. J., and De Bruin, R. H., 1979, Wyoming mines and minerals: Geological Survey of Wyoming Map Series MS-5, scale 1:500,000.

Heckathorn, B. R., Rathjen, R. A., Keetch, M. R., Hanson, M. L., 1976, Forestry: Portland, Oreg., U.S. Soil Conservation Service, Green River Basin, Wyoming, Type IV Study Working Paper, 39 p.

Heil, R. D., Romine, D. S., Moreland, D. C., Dansdill, R. K., Montgomery, R. H., and Cipra, J. E., 1977, Soils of Colorado: Colorado State University Experiment Station Bulletin 5665, 39 p.

Hem, J. D., 1970, Study and interpretation of the chemical characteristics of natural water: U.S. Geological Survey Water-Supply Paper 1473; 363 p.

Hudelson, Ralph, Boyer, Galen, and McMillian, Jack, 1980, High mountain lake and stream survey of the Bridger Wilderness Area-1969-75: Cheyenne, Wyo., Wyoming Game and Fish Depart ment, Fish Division, (approx.) 500 p.

Iorns, W. V., Hembree, C. H., and Oakland, G. L., 1965, Water resources of the Upper Colorado River Basin-Technical report: U.S. Geological Survey Professional Paper 441, 370 p.

James, H., and Evison, Lilian, editors, 1979, Biological indication of water quality: A Wiley-Interscience Publication, John Wiley and Sons, chap. 2, 45 p.

Kircher, J. E., 1982, Sediment transport and source areas of sediment and runoff, Big Sandy River Basin, Wyoming: U.S. Geological Survey Water-Resources Investigations Report $81-72,51 \mathrm{p}$.

Larson, L. R., and Zimmerman, E. A., 1981, Water resources of Upper Separation Creek Basin, southcentral Wyoming: U.S. Geological Survey WaterResources Investigations Report 80-85, 69 p.

Leopold, L. B., and Langbein, W. B., 1960, A primer on water: U.S. Geological Survey, 50 p.

Lidstone, C. D., 1982, Stream channel reconstruction and drainage basin stability, in Hydrology symposium on surface coal mines in Powder River Basin, Gillette, Wyo., Nov. 3-5, 1982: Gillette Area Ground-water Monitoring Organization and Northeast Wyoming Chapter, American Institute of Mining Engineers, Proceedings, p. 43-56.

Lines, G. C., and Glass, W. R., 1975, Water resources of the 
Mineral-thrust belt of western Wyoming: U.S. Geological Survey Hydrologic Investigations Atlas 539, 3 sheets.

Lowham, H. W., 1976, Techniques for estimating flow characteristics of Wyoming streams: U.S. Geological Survey Water-Resources Investigations Report 76-112, $83 \mathrm{p}$.

1978, An analysis of stream temperatures, Green River Basin, Wyoming: U.S. Geological Survey Water-Resources Investigations Report 78-13, 41 p. 1982, Streamflow and channels of the Green River basin, Wyoming: U.S. Geological Survey Water-Resources Investigations Report 81-71, $73 \mathrm{p}$

Lowham, H. W., Kircher, J. E., and Boner, F. C., 1975, Temperatures of Wyoming streams: Wyoming State Engineer's Office, Wyoming Water Planning Program Report No. 15, 115 p.

Lowham, H. W., DeLong, L. L., Peter, K. D., Wangness, D. J., and Head, W. J., 1976, A plan for study of water and its relation to economic development in the Green River and Great Divide Basins in Wyoming: U.S. Geological Survey Open-File Report 76-349, $92 \mathrm{p}$

Lowham, H. W., DeLong, L. L., Collier, K. R., and Hydrology of Salt Wells Creek-A plains stream in southwestern Wyoming: U.S. Geological Survey Water-Resources Investigations Report 81-62, 52 p.

Mallard, G. E., 1981, Micro-organisms in stormwater, in Greeson, P. E., ed., Microbiology of the aquatic environment: U.S. Geological Survey Circular 848-E, 33 p.

Miller, D. D., 1977, Comprehensive survey of the Bear River drainage: Cheyenne, Wyo., Wyoming Game and Fish Department, $81 \mathrm{p}$.

1977, Comprehensive survey of the Big Sandy River: Cheyenne, Wyo., Wyoming Game and Fish Department, $44 \mathrm{p}$.

National Academy of Sciences and National Academy of Engineering, 1973 [1974], Water quality criteria, 1972: U.S. Government Printing Office, 594 p.

National Oceanic and Atmospheric Administration, 1973, Monthly normals of temperature, precipitation, and heating and cooling degree days 1941-70, in Climatography of the United States: U.S. Department of Commerce, no. 81, 8 p.

National Park Service, 1982, The nationwide rivers inventory: Washington, D.C., looseleaf, 65 p.

O'Connell, D. J., 1969, Surface-water discharge and groundwater levels in the East Fork River area, Sublette County, Wyoming: U.S. Geological Survey Open-File Report, 77 p.

Oetking, Philip, Feray, D. W., and Renfro, H. B., 1967, Geological highway map of the southern Rocky Mountain region-Utah, Arizona, Colorado, New Mexico: American Association of Petroleum Geologists, United States Geological Highway Map Series, no. 2, scale approximately $1: 1,875,000$.

Office of Surface Mining, 1979, Surface mining and reclamation operations: permanent regulatory program: Federal Register, v. 44, no. 50, book 3, p. 15311-15463.

Petroleum Information Corporation, 1974, Geological structure map of Wyoming: Littleton, Colo., scale 1:500,000.

Phillips, Clynn, McDonald, Lyman, and Eastwood, John, 1981, 1979 Fishing pressure estimates for Wyoming streams and standing waters: Laramie, Wyo., University of Wyoming
Water Resources Research Institute, 28 p.

Rantz, S. E., and Eakin, T. E., 1971, A summary of methods for the collection and analysis of basic hydrologic data for arid regions: U.S. Geological Survey Open-File Report, $125 \mathrm{p}$.

Rathjen, R. A., Heckathorn, B. R., and Hanson, M. L., 1977, The agricultural base: Portland, Oregon, U.S. Soil Conservation Service, Green River Basin, Wyoming, Type IV Study Working Paper, $88 \mathrm{p}$.

Rechard, P. A., and Ragsdale, C. E., 1971, Compacts, treaties, and court decrees-Documents on the use and control of Wyoming's interstate streams: Wyoming State Engineer's Office, $163 \mathrm{p}$

Remmick, Ron, 1981, Comprehensive survey of the Green River westside tributaries: Cheyenne, Wyo., Wyoming Game and Fish Department, 157 p.

Renfro, H. B., and Feray, D. E., 1972, Geological highway map of the northern Rocky Mountain region-Idaho, Montana, Wyoming: American Association of Petroleum Geologists, United States Geological Highway Map Series, map no. 5, scale approximately $1: 1,875,000$

Robinove, C. J., and Berry, D. W., 1963, Availability of ground water in the Bear River Valley, Wyoming, with a section on chemical quality of the water, by J. G. Conner: U.S. Geological Survey Water-Supply Paper 1539-V, 44 p.

Robinove, C. J., and Cummings, T. R., 1963, Ground-water resources and geology of the Lyman-Mountain View area, Uinta County, Wyoming: U.S. Geological Survey WaterSupply Paper 1669-E, $43 \mathrm{p}$.

SAS Institute Inc., 1982, SAS user's guide-Statistics-1982 edition: Cary, North Carolina, 584 p.

Surface Mining Control and Reclamation Act of 1977-Public Law 95-87: 95th Congress of the United States, August 3, 1977, U.S. Statutes at Large, v. 91, p. 445-532.

Swanson, V. E., Medlin, J. E., Hatch, J. R., Coleman, S. L., Wood, G. H., Jr., Woodruff, S. D., and Hildebrand, R. T., 1976, Collection, chemical analysis, and evaluation of coal samples in 1975: U.S. Geological Survey Open-File Report 76-468, 503 p.

Tomlinson, R. J., 1981, The Wyoming travel/tourism industry: Cheyenne, Wyo., Wyoming Department of Economic Planning and Development, $149 \mathrm{p}$.

U.S. Bureau of Land Management, 1975, Preston, Idaho-Wyoming-Utah, Surface-Mineral Management Status: Boise, Idaho, 1:100,000-scale series map, 1 sheet.

1978a, State of Wyoming Land Status: Cheyenne, Wyo., map, scale $1: 1,000,000,1$ sheet.

1978b, Logan, Utah-Wyoming-Idaho, Surfacemineral Management Status: Salt Lake City, Utah, 1:100,000-scale series map, 1 sheet.

1978c, Ogden, Utah-Wyoming, Surface-Minerals Management Status: Salt Lake City, Utah, 1:000,000-scale series map, 1 sheet.

1979a, Canyon of Lodore, Colorado: Denver, Colo., $30 \times 60$ minute series map, scale $1: 100,000,1$ sheet. $1979 \mathrm{~b}$, State of Wyoming Mineral Status: Cheyenne, Wyo., map, scale 1:500,000, 1 sheet.

1981, Dutch John, Utah-Colorado-Wyoming: Salt Lake City, Utah, $30 \times 60$ minute series map, scale 1:100,000, 1 sheet.

1983, Kings Peak, Utah-Wyoming: Salt Lake City Utah, $30 \times 60$ minute series map, scale 
$1: 100,000,1$ sheet.

U.S. Department of Agriculture, 1972, Natural vegetation-Colorado: Denver, Colorado, U.S. Department of Agriculture Soil Conservation Service map, scale $1: 1,500,000$.

1977, Vegetative types and land resource areas-Utah: Salt Lake City, Utah, U.S. Department of Agriculture Soil Conservation Service map, 1:500,000.

1979, Potential natural vegetation-Idaho: Boise, Idaho, U.S. Department of Agriculture, Soil Conservation Service map, scale 1:3,500,000.

1980, Big Sandy River unit salinity study, Wyoming: Casper, Wyo., U.S. Soil Conservation Service, $189 \mathrm{p}$.

U.S. Environmental Protection Agency, 1975, National interim primary drinking water regulations: Federal Register, v. 40, no. 248, Wednesday, December 24, 1975, Part IV, p. 59566-59587. 1977a, Flaming Gorge Reservoir, Sweetwater County, Wyoming, EPA Region VIII: Corvallis, Oreg., National Eutrophication Survey Working Paper No. 885, 63 p.

1977b, Fremont Lake, Sublette County, Wyo ming, EPA Region VIII: Corvallis, Oreg., National Eutrophication Survey Working Paper No. 886, 13 p. 1977c, Quality criteria for water, 1976: U.S. Environmental Protection Agency, Washington, D.C., variable pagination.

1977d, Soda Lake, Sublette County, Wyoming, EPA Region VIII: Corvallis, Oregon, National Eutrophication Survey Working Paper No. 891, 8 p. 1977e, Viva Naughton Reservoir, Lincoln County, Wyoming, EPA Region. U.S. Fish and Wildlife Service, 1978a, 1978 Stream evaluation map, State of Wyoming: Denver, Colo., U.S. Fish and Wildlife Service, Office of Biological Services, 1 sheet.

1978b, 1978 Stream Evaluation Map, State of Idaho: Denver, Colo., U.S. Fish and Wildlife Service, Office of Biological Services, map scale 1:500,000, 1 sheet.

1978c, 1978 Stream Evaluation Map, State of Utah: Denver, Colo., U.S. Fish and Wildlife Service, Office of Biological Services, map scale 1:500,000, 1 sheet.

1979, 1979 Stream Evaluation Map, State of Colorado: Denver, Colo., U.S. Fish and Wildlife Service, Office of Biological Services, map scale 1:500,000, 1 sheet.

U.S. Geological Survey, 1964, 1976, and 1969; Wyoming, 1964, Colorado, 1969, and Utah and Idaho, 1976, State base maps: U.S. Geological Survey, scale $1: 500,000$.

U.S. Soil Conservation Service, 1972, Hydrology: Natural Engineering Handbook, section 4, chapter $16,26 \mathrm{p}$.

1973a, General soil map-Idaho: U.S. Department of Agriculture, scale 1:1,500,000.

1973b, General soil map-Utah: U.S. Department of Agriculture, scale 1:1,500,000.

U.S. Weather Bureau, 1965a, Mean annual precipitation,
1930-57, State of Idaho: U.S. Soil Conservation Service map, scale 1:1,700,000.

1965b, Normal annual precipitation, 1931-60, State of Utah: Utah State Engineer's Office, Utah Water and Power Board, and Soil Conservation Service map, scale 1:500,000.

1967, Normal annual precipitation, 1931-60, State of Colorado: U.S. Weather Bureau map, scale 1:500,000.

Wegner, D. L., 1982, Limnological Environment of Flaming Gorge Reservoir: Las Vegas, Nevada, paper presented at American Fisheries Society Western Division Meeting, 12 p.

Welder, G. E., 1968, Ground-water reconnaissance of the Green River Basin, southwestern Wyoming: U.S. Geological Survey Hydrologic Investigations Atlas, 290, 5 p., 3 sheets.

Welder, G. E., and McGreevey, L. J., 1966, Ground-water reconnaissance of the Great Divide and Washakie basins and some adjacent areas, southwestern Wyoming: U.S. Geological Survey Hydrologic Investigations Atlas 219, 10 p., 2 sheets.

Wyoming Department of Administration and Fiscal Control, 1981, Wyoming Data Handbook 1981: Wyoming Department of Administration and Fiscal Control, Division of Research and Statistics, 5th edition, 201 p., Department of Environmental Quality, 1977, Land Quality Division Guideline No. 4, Water Quality (Revised): Cheyenne, Wyo., 5 p.

1978, Land Quality Division Guideline No. 6, Organization and Topic Guideline for an Application: Cheyenne, Wyo., 14 p.

1979, Land Quality Division Guideline No. 2, Vegetation: Cheyenne, Wyo., 19 p.

1979, Land Quality Division Guideline No. 9, Alluvial Valley Floors: Cheyenne, Wyo., 16 p. 1980a, Land Quality Division Guideline No. 5, Wildlife: Cheyenne, Wyo., 18 p.

1980b, Land Quality Division Guideline No. 8, Hydrology: Cheyenne, Wyo., 18 p. 1981a, Land Quality Division Guideline No. 2, Vegetation: Cheyenne, Wyo., 19 p. 1981b, Land Quality Division Guideline No. 9, Alluvial Valley Floors: Cheyenne, Wyo., 16 p.

1982, Rule and regulations: Cheyenne, Wyo., Department of Environmental Quality, Land Quality Division Report, 178 p.

Wyoming Geological Association, 1969, Wyoming stratigraphic nomenclature chart: Wyoming Geological Association Stratigraphic Nomenclature Committee, Casper, Wyo., chart.

Wyoming State Inspector of Mines, 1962-82, Annual report of the State Inspector of Mines 1962-82: State of Wyoming (published annually since 1902), $61 \mathrm{p}$.

Wyoming State Engineer, 1970, Tabulation of existing Wyoming reservoirs over 500 acre-feet capacity: Cheyenne, Wyo., Wyoming Water Planning Program Report No. 4, 30 p.

Young, J. F., and Singleton, P. C., 1977, Wyoming general soil map: University of Wyoming Agricultural Experiment Station Research Journal, no. $117,40 \mathrm{p}$. 